Portland State University

PDXScholar

\title{
Mid-Miocene Icelandites of Eastern Oregon: Petrogenesis and Magmatic Lineage to Main-Phase CRBG with Constraints on Storage Sites
}

Melissa Aileen Carley

Portland State University

Follow this and additional works at: https://pdxscholar.library.pdx.edu/open_access_etds

Part of the Geology Commons

Let us know how access to this document benefits you.

Recommended Citation

Carley, Melissa Aileen, "Mid-Miocene Icelandites of Eastern Oregon: Petrogenesis and Magmatic Lineage to Main-Phase CRBG with Constraints on Storage Sites" (2021). Dissertations and Theses. Paper 5818. https://doi.org/10.15760/etd.7689

This Thesis is brought to you for free and open access. It has been accepted for inclusion in Dissertations and Theses by an authorized administrator of PDXScholar. Please contact us if we can make this document more accessible: pdxscholar@pdx.edu. 
Mid-Miocene Icelandites of Eastern Oregon:

Petrogenesis and Magmatic Lineage to Main-Phase CRBG with

Constraints on Storage Sites

by

Melissa Aileen Carley

A thesis submitted in partial fulfillment of the requirements for the degree of

Master of Science

in

Geology

Thesis Committee:

Martin J. Streck, Chair

John Bershaw

Barry Walker Jr.

Portland State University

2021 


\section{Abstract}

The La-Grande Owyhee eruptive axis is a mid-Miocene to Pliocene $\sim 300 \mathrm{~km}$ long volcanic belt located at the eastern margin of the Columbia River Basalt Group (CRBG) in Oregon. Within this volcanic belt there are numerous vents that have produced a large volume of petrologically diverse rocks ranging from the tholeiitic flood basalts of the CRBG to rhyolitic tuffs of caldera complexes such as the Lake Owyhee Volcanic field. Icelandites, which are iron rich andesites, are known to occur in association with silica saturated to oversaturated tholeiitic basalts as a minor part of continental flood basalt volcanism. This study investigates these icelandites. This includes summarizing their currently known extent, documenting their compositional variations, describing their lithologic and petrographic characteristics, and to petrogenetically relate icelandite magmas to main stage CRBG magmas..

Prior mapping and our work in eastern Oregon have revealed numerous occurrences of mid-Miocene Fe-rich andesite (icelandite) lavas among flood basalts and rhyolites of the Columbia River magmatic province in eastern Oregon from north of Baker City to McDermitt along the Oregon-Nevada state border. Icelandite lavas typically overlie main units of the Columbia River Basalt Group (CRBG) and are intercalated with mid-Miocene rhyolites. This stratigraphic control and select radiometric ages (new and existing) indicate they range in age from $>16 \mathrm{Ma}$ (e.g., 16.1) to 15 Ma suggesting icelandites represent the last pulse of main phase CRBG volcanism. Icelandites are found in 
proximal mafic pyroclastic deposits, lava flows or as magmatic components in strongly zoned (rhyolite-icelandite) ignimbrites.

Our compiled data set in combination with published data are used to investigate processes involved in formation of these rocks. Icelandites of eastern Oregon range from $\sim 57$ to $63 \mathrm{wt} \% \mathrm{SiO}_{2}$, with $>8 \mathrm{wt} \% \mathrm{FeO}^{*}$ and as high as 13.4 . $\mathrm{FeO} * / \mathrm{MgO}$ can be as high as 14 and $\mathrm{Mg}$ \# ranges from 7.1 to 26.1 . Although $\mathrm{FeO} *$ and $\mathrm{FeO} / \mathrm{MgO}$ is characteristically high in all samples, there are subtle differences within icelandites yielding two groups that internally vary with increased silica as discerned mostly by $\mathrm{Nb}$, $\mathrm{Ta}, \mathrm{Zr}, \mathrm{Hf}, \mathrm{Th}$, and rare earth elements. The trace element enriched Group 1 has lower $\mathrm{Al}_{2} \mathrm{O}_{3}$ content than the samples of the trace element depleted Group 2. Internally, both groups vary in their $\mathrm{TiO}_{2}$ that decreases with increased $\mathrm{SiO}_{2}$. The two icelandite groups are petrogenetically modeled as being derived from main phase CRBG. The more enriched Group 1 is more consistent with a parent magma similar to the Imnaha Basalt. The compositions of the less enriched Group 2 are consistent with a Picture Gorge Basalt parent magma and Grande Ronde basaltic andesite samples (including Hunter Creek and Birch Creek samples of the Malheur Gorge area) as intermediary compositions. This suggests that the majority of these icelandites are the products of continued magmatic evolution from magmas of the Grande Ronde Basalt through a combination of processes including fractionation and mixing with felsic material such as a rhyolite or contamination with country rock. 


\section{Acknowledgements}

First and foremost, I would like to thank my advisor Dr Martin Streck for his support and guidance on this journey. You entrusted me with a project both fascinating and challenging that has given me a lifelong obsession with boring aphyric rocks full of mysteries waiting to be unlocked. Thank you to my friends and family at PSU and beyond for all the love and support they've provided over the past several years. To my fellow grad students, you have been the most wonderful group of women and men, and it's been my honor to work alongside all of you. I want to give special thanks to $\mathrm{Dr}$ Daniel Heaton at OSU for taking photos of my thin sections for me during the COVID lockdown. Thank you to Cassie Geraghty for opening your home to me while I was at WSU and for being a great friend.

Finally, I want to thank Keith Olson, my partner, for always being so supportive and willing to lend a hand throughout my research. You are the best field/lab assistant I could have ever asked for. Thank you for putting up with all the long hours and my constant trips going back and forth between Corvallis and Portland. 


\section{Table of Contents}

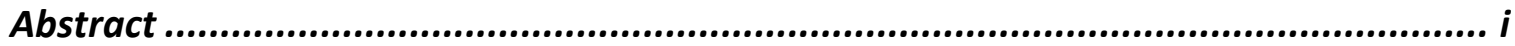

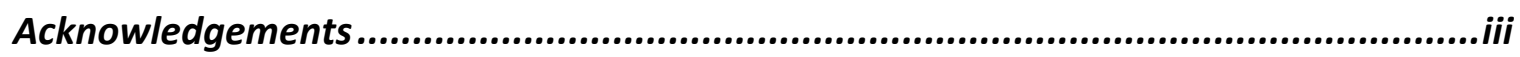

List of Tables ................................................................................................... vi

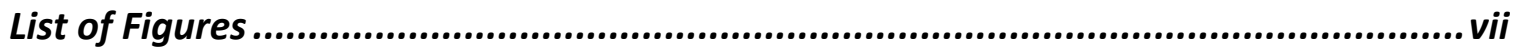

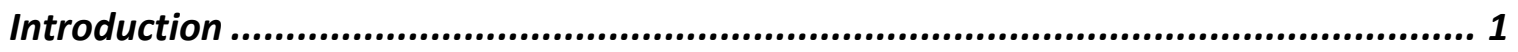

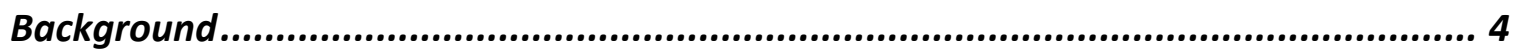

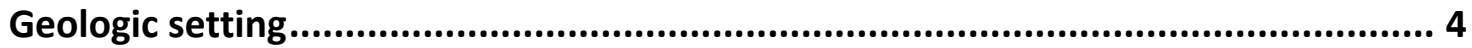

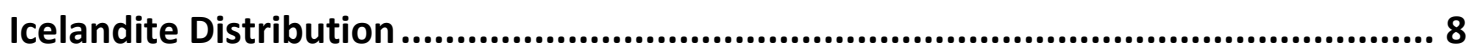

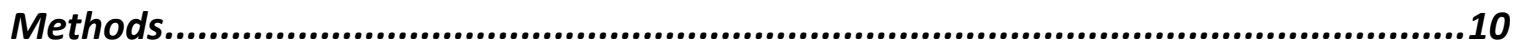

Sample Collection .........................................................................................10

Preparation and Geochemical Analysis .........................................................11

Petrographic and SEM Analysis.................................................................12

Geochemical Modeling ....................................................................................13

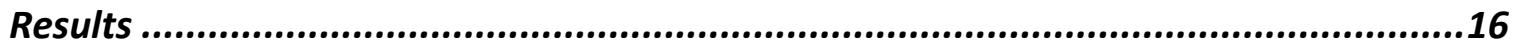

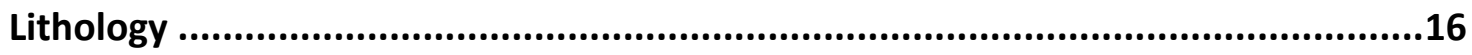

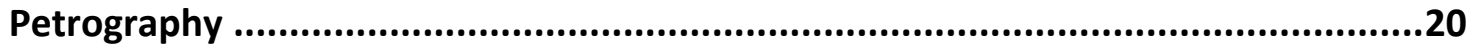

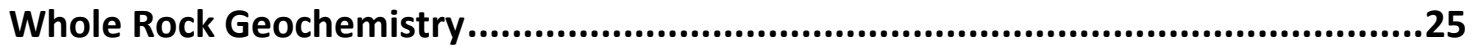

Composition of Phenocrystic Minerals........................................................45

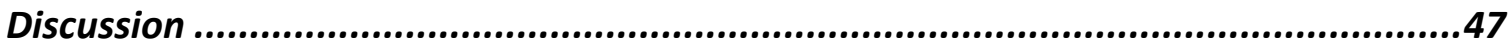

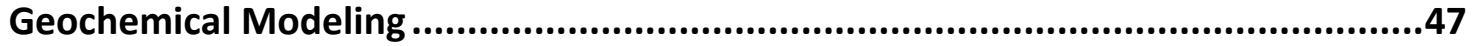

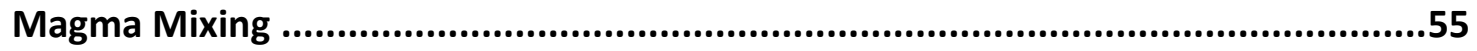

Regional Distribution ...........................................................................61

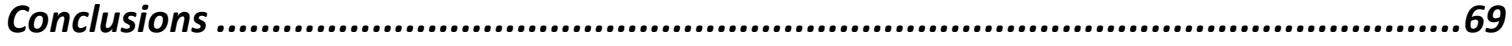

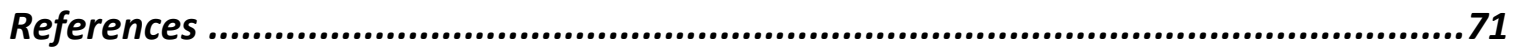

Appendix A: Whole Rock Geochemical Data ......................................................87

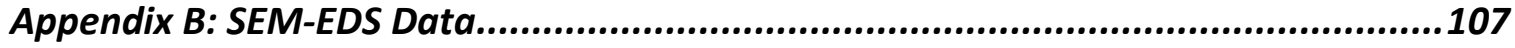

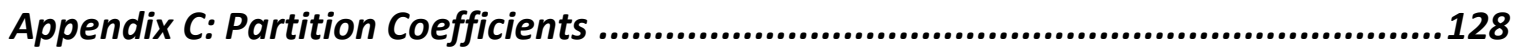

Appendix D: Fractional (Rayleigh) Crystallization Model........................................130

Appendix E: Magma Mixing Model..............................................................136 
Lower Littlefield Rhyolite Mixing Plots......................................................138

Upper Littlefield Rhyolite Mixing Plots.........................................................140

Dinner Creek Tuff Unit 1 Mixing Plots .......................................................142

Dinner Creek Tuff Unit 2 Mixing Plots ...............................................................144

Dinner Creek Tuff Unit 3 Mixing Plots ...........................................................146

Dinner Creek Tuff Unit 4 Mixing Plots .........................................................148

Appendix F: Petrographic Analysis.............................................................150 


\section{List of Tables}

Table 1. Ranges for major element concentrations in icelanditic rocks. Data for this table can be found in Appendix A. ............................................................... 27

Table 2. Ranges for selected trace element and REE concentrations in icelanditic rocks. Data used for this table can be found in Appendix A........................................ 28

Table 3. Mineral proportions used for icelandite groups in fractional crystallization model.

Table 4. Estimated mineral chemistry for major rock forming minerals of mid-Miocene icelandites and calculated bulk mineral used for crystalization models of group 1 and 2 icelandites.

Table 5. Selected ages of mid-Miocene icelanditic units and components. 


\section{List of Figures}

Figure 1. Map showing La Grande-Owyhee eruptive axis and the first two stages in the evolution along it. Regional features are as follows: WA-Washington; OROregon; ID-Idaho; LG_La Grande graben; CRBG - Columbia River Basalt Group; BG-Baker graben; OIG-Oregon-Idaho graben; CR-Castle Rock Caldera; SMStrawberry Volcanics; IM-Ironside Mountain; SD-Steens Dike Swarm; MDMonument dike swarm; CJD-Chief Joseph dike swarm; LFR—Littlefield Rhyolite; CM-Rhyolite of Cottonwood Mountain; WSRP-Western Snake River Plain. Extent of the Columbia River Basalt Group, stage 1 flood basalts (blue shade), in eastern Oregon. Extent of stage 2 icelandite lavas (pre-2017 extent) along the eruptive axis shown in orange shade(from Ferns and McClaughry, 2013). Published data points (pre-2017 samples) taken from previous work by: Bailey (1989), Binger (1997), Brooks (1992, 2006), Brooks and O’Brien (1992a,b), Brueseke and Hart (2007), Camp et al. (2003), Edwards (2013), Ferns and McClaughry (2013), Ferns and McConnell (2005), Ferns et al (2010), Ferns (1989a), Ferns and O’Brien (1992a,b), Hooper et al. (2002a), Korosec (1987), Lees (1994), MacLeod (1990a), Madin (1997), Wright (1979) and Wright et al. (1980) and Zimmerman (1991)................. 2

Figure 2. Stratigraphic column illustrating the major subdivisions of the Columbia River Basalt Group.(from Reidel et al., 2013).

Figure 3. Correlation diagram of stratigraphic relationships between mapped units of the La Grande-Owyhee eruptive axis. The Dinner Creek Tuff, shown in gray, is exposed over a wide geographic area from north to south along the eruptive axis. Magnetic polarities are listed within the Grande Ronde Basalt identify magnetostratigraphic units defined by Reidel et al. (2013). Abbreviations: Ma, mega-annum (million years before present); “(?)," stratigraphic position uncertain. (Figure from Ferns, et al., 2017).

Figure 4. Map of study area in eastern Oregon. Mapped extent of icelandites prior to 2017 fieldwork is shown in orange shade. CRBG extent is shown in blue shade. Base map from ArcGIS online library.

Figure 5. Map of northern half of study area. Regional features are as follows: WAWashington; OR-Oregon; ID-Idaho; LG-La Grande graben; BG-Baker graben; Mapped extent of icelandites prior to 2017 fieldwork is shown in orange shade. CRBG extent is shown in blue shade. Base map from ArcGIS online library.

Figure 6. Map of Southern half of study area. Regional features are as follows: WAWashington; OR-Oregon; ID-Idaho; OIG-Oregon-Idaho graben; CR-Castle Rock Caldera; SM-Strawberry Volcanics; IM-Ironside Mountain; LFR-Littlefield Rhyolite; $\mathrm{CM}$-Rhyolite of Cottonwood Mountain; Mapped extent of icelandites prior to 2017 fieldwork is shown in orange shade. CRBG extent is shown in blue shade. Base map from ArcGIS online library. 
Figure 7. Photomicrograph of clinopyroxene and plagioclase feldspar phenocrysts in plain polarized light (PPL) and cross-polarized light (XPL) for sample MAC-17-04a. The field of view for both images is $9 \mathrm{~mm}$ in width. Images taken under $4 \mathrm{x}$ magnification. Thin sections images courtesy of Dr. Daniel Heaton of Oregon State University.

Figure 8. Photomicrograph of clinopyroxene and plagioclase feldspar phenocrysts in plain polarized light (PPL) and cross-polarized light (XPL) for sample MAC-17-06. The field of view for both images is $9 \mathrm{~mm}$ in width. Images taken under $4 \mathrm{x}$ magnification. Thin sections images courtesy of Dr. Daniel Heaton of Oregon State University

Figure 9. Photomicrograph of clinopyroxene and plagioclase feldspar phenocrysts in plain polarized light (PPL) and cross-polarized light (XPL) for sample MAC-17-06. The field of view for both images is $9 \mathrm{~mm}$ in width. Images taken under $4 \mathrm{x}$ magnification. Thin sections images courtesy of Dr. Daniel Heaton of Oregon State University.

Figure 10. Plot of $\mathrm{FeO} * \mathrm{MgO}$ ratio versus silica content CRBG main phase members, Basalt of Malheur Gorge, Picture Gorge Basalt, Hunter Creek Basalt, icelandite groups of this study and previously published icelandites of CRBG from Carlson and Hart (1987), Bailey (1989), Hooper and Swanson (1990), Hooper and Hawkesworth (1993), Hooper (2000), Hooper et al. (2002), Lees (1994), Binger (1997), Reidel (1998), Reidel and Tolan (2013), Camp et al. (2003), Brueseke and Hart (2007), and

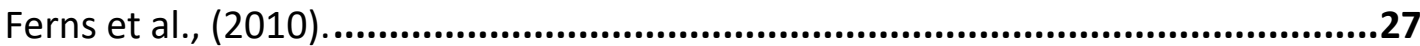

Figure 11. Total alkali versus silica content diagram (after Le Bas et al., 1986, Fig. 1) for main phase CRBG members, Picture Gorge Basalts, Basalt of Malheur Gorge, Hunter Creek Basalt, and icelandite units of this study. Analyses are from Carlson and Hart (1987), Bailey (1989), Hooper and Swanson (1990), Hooper and Hawkesworth (1993), Hooper (2000), Hooper et al. (2002) Lees (1994), Binger (1997), Reidel (1998), Reidel and Tolan (2013), Camp et al. (2003), Brueseke and Hart (2007), and Ferns et al., (2010). Data from this study used for plotting can be found in Appendix A.

Figure 12. Major element x-y plots for $\mathrm{TiO}_{2}, \mathrm{Al}_{2} \mathrm{O}_{3}, \mathrm{FeO}^{*}$, and $\mathrm{MgO}$ wt $\%$ vs. $\mathrm{SiO}_{2}$ wt\% for main phase CRBG members, Hunter Creek Basalt, Picture Gorge Basalt, and icelandites of this study. Data used for these plots can be found in Appendix A.....30

Figure 13. Major element $\mathrm{x}-\mathrm{y}$ plots for $\mathrm{Na}_{2} \mathrm{O}$ wt \%, $\mathrm{K}_{2} \mathrm{O}$ wt \%, $\mathrm{FeO} * \mathrm{MgO}$, and $\mathrm{Mg} \#$ vs. $\mathrm{SiO}_{2}$ wt\% for main phase CRBG members, Hunter Creek Basalt, Picture Gorge Basalt, and icelandites of this study. Data used for these plots can be found in Appendix A 
Figure 14. Primitive mantle normalized (Sun and McDonough, 1989) trace element diagram for averages of main phase CRBG members, Hunter Creek Basalt, published icelandites, and icelandites of this study. These values can be found in Appendix A...............................................................................................33

Figure 15. C1 chondrite (McDonough and Sun, 1995) normalized REE diagram for averages of main phase CRBG members, Hunter Creek Basalt, published icelandites, and icelandites of this study. These values can be found in Appendix A.

Figure 16. Primitive mantle normalized (Sun and McDonough, 1989) trace element diagram and C1 chondrite normalized (McDonough and Sun, 1995) REE diagram for average values of each icelandite group. These values can be found in Appendix A.

Figure 17. Major-trace element $\mathrm{x}-\mathrm{y}$ plot $\mathrm{Rb}$ and $\mathrm{Ba} \mathrm{vs} . \mathrm{SiO}_{2} \mathrm{wt} \%$ for main phase CRBG members, Hunter Creek Basalt, Picture Gorge Basalt, Dinner Creek Tuff, Littlefield Rhyolite and icelandites of this study. Data used for plots can be found in Appendix A. DIT samples from 60-65\% SiO2 are Laser ablation ICP-MS for mafic globules in the Dinner Creek Tuff,

Figure 18. Major-trace element $\mathrm{x}-\mathrm{y}$ plot for $\mathrm{Y}$ and $\mathrm{Nb}_{\mathrm{vs}} \mathrm{SiO} \mathrm{Si}_{2} \mathrm{wt} \%$ for main phase CRBG members, Hunter Creek Basalt, Picture Gorge Basalt, Dinner Creek Tuff, Littlefield Rhyolite, and icelandites of this study. Data used for plots can be found in Appendix A. DIT samples from 60-65\% SiO2 are Laser ablation ICP-MS for mafic globules in the Dinner Creek Tuff,

Figure 19. Major-trace element $\mathrm{x}$-y plots for Th and $\mathrm{Ta}_{\mathrm{vs}} \mathrm{\textrm {SiO } _ { 2 }}$ wt\% for main phase CRBG members, Hunter Creek Basalt, Picture Gorge Basalt, Dinner Creek Tuff, Littlefield Rhyolite and icelandites of this study. Data used for these plots can be found in Appendix A. DIT samples from 60-65\% SiO2 are Laser ablation ICP-MS for mafic globules in the Dinner Creek Tuff,

Figure 20. Plots of rare earth elements (REE) vs. $\mathrm{SiO}_{2}$ wt\% for main phase CRBG members, Hunter Creek Basalt, Picture Gorge Basalt, and icelandites of this study. Data used for these plots can be found in Appendix A.

Figure 22. Plots of rare earth elements (REE) vs. $\mathrm{SiO}_{2} \mathrm{wt} \%$ for main phase CRBG members, Hunter Creek Basalt, Picture Gorge Basalt, and icelandites of this study. Data used for these plots can be found in Appendix A.

Figure 23. Plots of rare earth elements (REE) vs. $\mathrm{SiO}_{2}$ wt\% for main phase CRBG members, Hunter Creek Basalt, Picture Gorge Basalt, and icelandites of this study. Data used for these plots can be found in Appendix A. 
Figure 24. Ternary diagram of representative single point compositions for plagioclase feldspar phenocrysts determined by SEM-EDS analysis. Data used for plot can be found in Appendix C.

Figure 25. Ternary diagram of the representative single point compositions of clinopyroxene phenocrysts determined by SEM-EDS analysis. Data used for plot can be found in Appendix C

Figure 26. Electron image of site 4 containing apatite microphenocryst within phenocryst of clinopyroxene from sample MAC-17-16.

Figure 27. Variation diagrams of Group 1 icelandites and mass balance modeling results for the two important major elements, Fe and Ti. The blue line is the calculated crystallization path using the calculated assemblage beginning at $42 \% \mathrm{SiO}_{2}$ (blue diamond) from the mafic parent magma (red triangle), each tick mark (blue diamonds) along the crystallization line represents crystallization increments of $5 \%$. Labeled points include the samples of group 1 as well as averages of the transition, low $\mathrm{SiO}_{2}$, and group 1 icelandites. Detailed results of the mass balance model can be found in appendix $D$

Figure 28. Variation diagrams of Group 2 icelandites and mass balance modeling results for the two important major elements, Fe and Ti. The blue line is the calculated crystallization path using the calculated assemblage beginning at $43 \% \mathrm{SiO}_{2}$ (blue diamond) from the mafic parent magma (red triangle), each tick mark (blue diamonds) along the crystallization line represents crystallization increments of $5 \%$. Labeled points include the samples of group 1 as well as averages of the transition, low $\mathrm{SiO}_{2}$, and Group 2 icelandites. Detailed results of the mass balance model can be found in appendix D

Figure 29. Spider diagram and REE diagram with fractional crystallization models, estimated parent, and observed Group 1 compositions.

Figure 30. Spider diagram and REE diagram with fractional crystallization models, estimated parent, and observed Group 2 compositions

Figure 31. Primitive mantle normalized (Sun and McDonough, 1989) trace element diagram and C1 chondrite normalized REE (McDonough and Sun, 1995) diagram for results of mixing of averaged group 1 CRBG mafic endmember (determined by linear regression of group 1 icelandite concentrations) with Upper Littlefield Rhyolite. These values and the calculations for the mixing model can be found in Appendix E.

Figure 32. Primitive mantle normalized (Sun and McDonough, 1989) trace element diagram and C1 chondrite (McDonough and Sun, 1995) normalized REE diagram for mixing results of CRBG mafic endmember (determined by linear regression of 
group 2 icelandite concentrations) with DIT units 1 through 4 to generate group 2 compositions. (see Appendix $\mathrm{E}$ for compositions of mixing model).

Figure 33. Primitive mantle normalized (Sun and McDonough, 1989) trace element diagram and C1 chondrite (McDonough and Sun, 1995) normalized REE diagram for mixing results of CRBG mafic endmember (determined by linear regression of group 2 icelandite concentrations) with DIT unit 3 to generate group 2 compositions. (see Appendix E for compositions of mixing model)

Figure 34. Primitive mantle normalized (Sun and McDonough, 1989) trace element diagram and C1 chondrite (McDonough and Sun, 1995) normalized REE diagram for mixing results of CRBG mafic endmember (determined by linear regression of group 2 icelandite concentrations) with DIT unit 4 to generate group 2 compositions. (see Appendix $\mathrm{E}$ for compositions of mixing model).

Figure 35. Plot of total alkali versus silica content mid-Miocene icelandites of this study, capping andesites of Folly Farm West, icelanditic rocks of the McDermitt Volcanic Field, and icelanditic rocks of the Santa Rosa-Calico Volcanic Field. Analyses are from this study, Brueseke and Hart (2007) and Brueseke et al. (2009), and Starkel (2014).

Figure 36. Regional distribution of icelandites including those of this study, FFWtholeiitic andesites of Folly Farm West in Lambing Canyon, MCD-icelandites of the McDermitt Volcanic Field, SRC-icelandites of Santa Rosa-Calico Volcanic Field. Regional features are as follows: WA-Washington; OR-Oregon; ID-Idaho; LGLa Grande graben; BG-Baker graben; OIG-Oregon-Idaho graben; CR-Castle Rock Caldera; SM-Strawberry Volcanics; IM-Ironside Mountain; LFR-Littlefield Rhyolite; CM-Rhyolite of Cottonwood Mountain; WSRP-Western Snake River Plain

Figure 37. Plot of total alkali versus silica content mid-Miocene icelandites of this study, capping andesites of Folly Farm West, icelanditic rocks of the McDermitt Volcanic Field, and icelanditic rocks of the Santa Rosa-Calico Volcanic Field. Analyses are from this study, Brueseke and Hart (2007) and Brueseke et al. (2009), and Starkel (2014).

Figure 38. Plot of $\mathrm{FeO}^{*} / \mathrm{MgO}$ ratio versus silica content mid-Miocene icelandites of this study, capping andesites of Folly Farm West, icelanditic rocks of the McDermitt Volcanic Field, and icelanditic rocks of the Santa Rosa-Calico Volcanic Field. Analyses are from this study, Brueseke and Hart (2007) and Brueseke et al. (2009), and Starkel (2014). .66

Figure 39. Primitive mantle normalized (Sun and McDonough, 1989) trace element diagram and C1 chondrite (McDonough and Sun, 1995) normalized REE diagram of 
averaged values of Grande Ronde Basalt, Hunter Creek basalt, icelandites of this study, and icelanditic rocks of the Santa Rosa-Calico Volcanic Field, McDermitt Volcanic Field and tholeiitic andesites of Lambing Canyon in Folly Farm West. ......67 


\section{Introduction}

The lava flows of the mid-Miocene Columbia River Basalt Group (CRBG) cover $\sim 200,000$ $\mathrm{km}^{2}$ in Oregon, Washington, and Idaho. The La Grande-Owyhee eruptive axis lies between the main outcrop area of the CRBG exposed across the Columbia plateau in the north and mid-Miocene bimodal eruptive centers exposed in the Owyhee plateau to the south (Ferns and McClaughry, 2013). It is in the La Grande-Owyhee eruptive axis and surroundings that geochemically and petrologically diverse suites of magmas ranging from tholeiitic, silicic, and calc-alkaline, to alkalic compositions have been erupted throughout the mid-Miocene and into the Pliocene of which some are not well studied. On the other hand, the main CRBG lavas to the north, exclusively comprising tholeiitic flood basalts, have been highly studied, and CRBG lavas west and south of the Baker graben are more intimately associated with silicic and intermediate compositions (Ferns and McClaughry, 2013).

Included in CRBG volcanism that started at 17.2 Ma (Cahoon, 2020) is the eruption of highly evolved tholeiitic andesites (icelandites) at several locations along the length of the eruptive axis (Figure 1B). Lavas classified as icelandite lavas have $\mathrm{SiO}_{2}$ of $57-64 \mathrm{wt} \%$, total $\mathrm{FeO}>8 \mathrm{wt} \%$, less than $16.5 \mathrm{wt} \% \mathrm{Al}_{2} \mathrm{O}_{3}, \mathrm{TiO}_{2}<3$ wt\% and low alkali content (Carmichael, 1964; Irvine and Baragar, 1971). The much higher iron content of icelandites is a characteristic difference to typical andesites of volcanic arcs. 


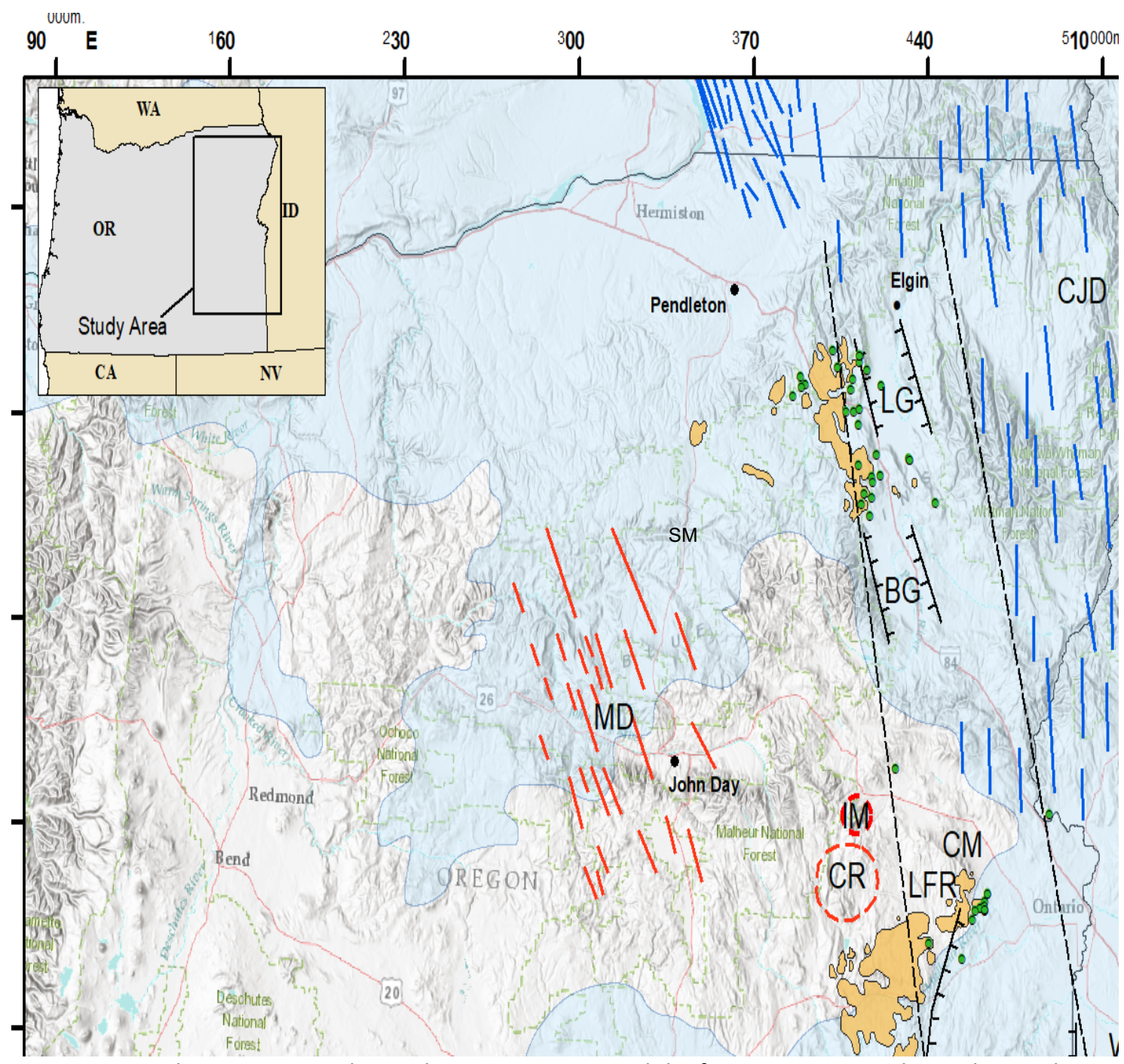

Figure 1. Map showing La Grande-Owyhee eruptive axis and the first two stages in the evolution along it. Regional features are as follows: WA-Washington; OR-Oregon; ID-Idaho; LG - La Grande graben; CRBG - Columbia River Basalt Group; BG-Baker graben; OIG-Oregon-Idaho graben; CR-Castle Rock Caldera; SM-Strawberry Volcanics; IM-Ironside Mountain; SD-Steens Dike Swarm; MD-Monument dike swarm; CJD-Chief Joseph dike swarm; LFR-Littlefield Rhyolite; CM-Rhyolite of Cottonwood Mountain; WSRP-Western Snake River Plain. Extent of the Columbia River Basalt Group, stage 1 flood basalts (blue shade), in eastern Oregon. Extent of stage 2 icelandite lavas (pre-2017 extent) along the eruptive axis shown in orange shade (from Ferns and McClaughry, 2013). Published data points (pre-2017 samples) taken from previous work by: Bailey (1989), Binger (1997), Brooks (1992, 2006), Brooks and O'Brien (1992a,b), Brueseke and Hart (2007), Camp et al. (2003), Edwards (2013), Ferns and McClaughry (2013), Ferns and McConnell (2005), Ferns et al (2010), Ferns (1989a), Ferns and O'Brien (1992a,b), Hooper et al. (2002a), Korosec (1987), Lees (1994), MacLeod (1990a), Madin (1997), Wright (1979) and Wright et al. (1980) and Zimmerman (1991).

The term icelandite was first coined by I.S.E. Carmichael in his 1964 study of the petrology of the Tertiary Thingmuli volcano in eastern Iceland to describe iron-rich 
alumina-poor andesites that were geochemically different from orogenic andesites. Subsequent research by several authors in the decades since Carmichael's study on Thingmuli has been able to better identify the major element geochemical characteristics of icelanditic lavas. Icelandites differ most consistently from orogenic andesites at plate boundaries by being enriched in $\mathrm{Fe}, \mathrm{Mn}, \mathrm{P}$, and Ti but depleted in $\mathrm{Al}$, Ca, and Mg at any given silica content (Gill, 1981). In the years since the study of Thingmuli, icelandites have been found to primarily exist in large igneous provinces such as Etendeka-Parana, Columbia River Basalt Group, North Shore Volcanic GroupKeweenawan Plateau lavas, and the North Atlantic Igneous Province (NAIP), the intracontinental volcanics of the Dongargarh fold belt in India as well as rift margins such as Iceland. The icelandites associated with the Columbia River Basalt Group are subject of this study. This includes summarizing their currently known extent, documenting their compositional variations, describing their lithologic and petrographic characteristics, and to petrogenetically relate icelandite magmas to main stage CRBG magmas. 


\section{Background}

GEOLOGIC SETTING

The Columbia River Basalt Group (CRBG; Figure 1) constitutes the Earth's youngest large igneous province (Barry et al., 2013). The Columbia River flood basalt province covers most of eastern Washington and Oregon, western Idaho, and part of northern Nevada (Reidel et al., 2013). Eruptive activity within the CRBG was generally agreed to have begun in the mid-Miocene at 16.8 Ma (Barry et al., 2013) but new data suggest that it started earlier at 17.2 (Cahoon, 2020). The Columbia River Basalt Group is estimated to have a total volume of $210,000 \mathrm{~km}^{3}$ and an areal extent of $208,000 \mathrm{~km}^{2}$ (Reidel et al., 2013). The members included in the CRBG are the Steens Basalt, Imnaha, Grande Ronde, Wanapum, and Saddle Mountain Basalts as well as the Picture Gorge Basalt and Prineville Basalt (Reidel and Tolan, 2013; Figure 2). 


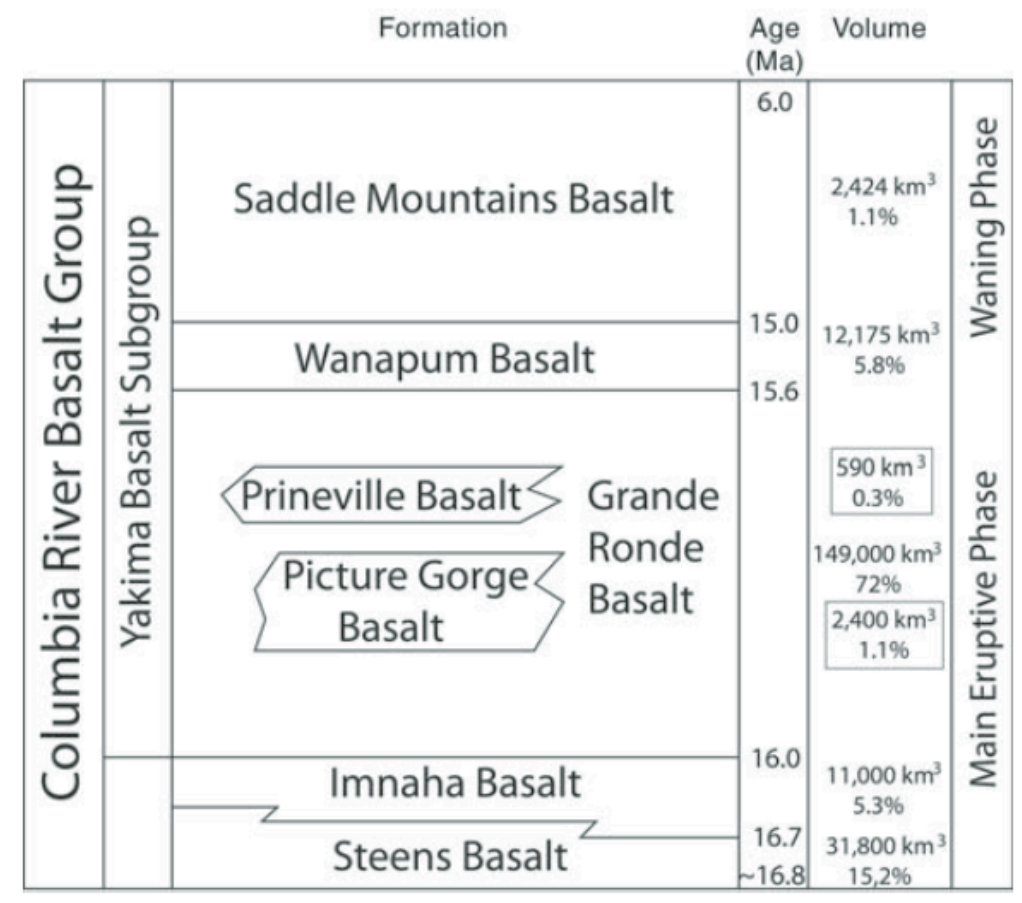

Figure 2. Stratigraphic column illustrating the major subdivisions of the Columbia River Basalt Group. (from Reidel et al., 2013).

More recent studies utilizing advancements in mapping and geochronological analyses have suggested that the basalt of Malheur Gorge, which is located to the south of most of the original main phase units (Imnaha and Grande Ronde Basalts), is a lava flow package composed of Steens Basalt at the base, Imnaha Basalt in the middle and Grande Ronde Basalt on top and thus represents an area were CRBG lavas from the north (Imnaha and Grand Ronde Basalt) overlap (Figure 3) with those lavas coming from the south (Steens Basalt) (Hooper et al., 2002; Camp et al., 2003). Newest data now suggest that lavas of the Picture Gorge Basalt reach into the Malheur Gorge area as well (Cahoon, 2020). 


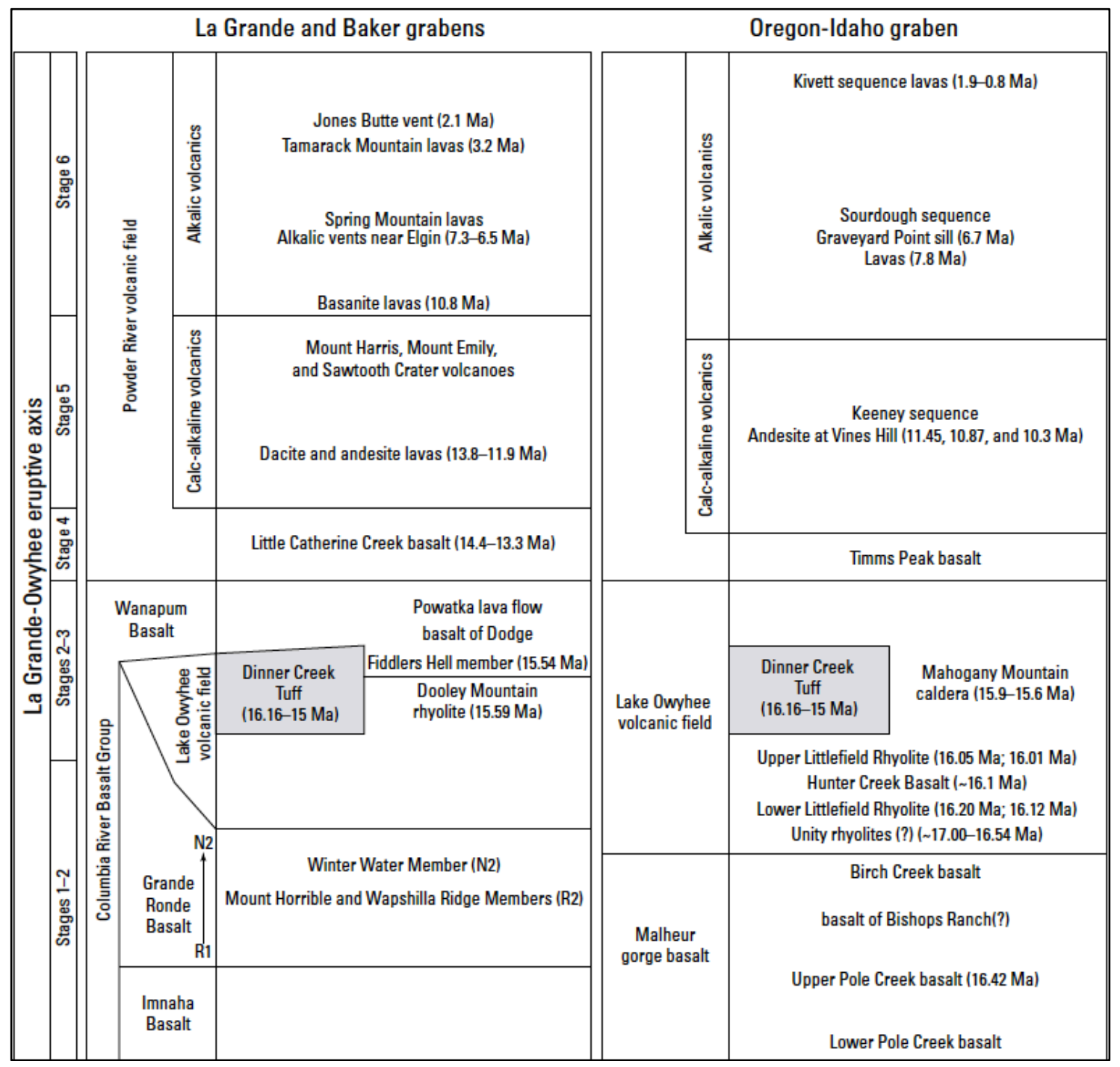

Figure 3. Correlation diagram of stratigraphic relationships between mapped units of the La GrandeOwyhee eruptive axis. The Dinner Creek Tuff, shown in gray, is exposed over a wide geographic area from north to south along the eruptive axis. Magnetic polarities are listed within the Grande Ronde Basalt identify magnetostratigraphic units defined by Reidel et al. (2013). Abbreviations: Ma, mega-annum (million years before present); "(?)," stratigraphic position uncertain. (Figure from Ferns, et al., 2017).

The Grande Ronde Basalt represents the main pulse of Columbia River Basalt Group

volcanism (Swanson et al., 1979a). Grande Ronde eruptive activity began in the mid-

Miocene from the end of the Imnaha Basalt at $16.4 \mathrm{Ma}$ to the end of the Grande Ronde

Basalt volcanism at $15.9 \mathrm{Ma}$ (Wolff and Ramos, 2013). Flows of the Grande Ronde

Basalt erupted from the Chief Joseph dike swarm of northeastern Oregon/southwestern 
Washington and produced $150,400 \mathrm{~km}^{3}$ of basaltic lavas that covered $\sim 169,600 \mathrm{~km}^{2}$. These are among the largest known lava flows on Earth (Figure 2) and provide an excellent example of the magnitude of flood basalt volcanism (Reidel and Tolan, 2013). The La Grande-Owyhee eruptive axis (LOEA) in eastern Oregon is a north-northwest trending, 300 km long mid-Miocene to Pliocene volcanic belt located near the eastern margin of the CRBG province (Ferns and McClaughry, 2013). The eruptive axis extends from the town of Elgin on the north to the town of Jordan Valley on the south and is juxtaposed between the Chief Joseph dike swarm on the east and the Monument dike swarm and the middle Miocene Strawberry Volcanics on the west (Figure 1). It is defined by numerous volcanic vents, contained within or directly adjacent to the La Grande, Baker, and Oregon-Idaho grabens, from which a diverse assemblage of tholeiitic, silicic, calcalkaline, and alkalic lavas erupted (Ferns and McClaughry, 2013). The volcanic rocks that erupted from and are preserved within the eruptive axis stratigraphically link northern exposures of CRBG units with correlative mid Miocene basaltic lavas exposed over vast parts of SE Oregon and Northern Nevada (Ferns and McClaughry, 2013).

Volcanism along the LOEA progressed through six stages, beginning in the middle Miocene and continuing through the Pliocene. Stage 1 (17.2-15.5) in the evolution of the eruptive axis were the fissure eruptions of the Grande Ronde Basalt member of the CRBG. The 2nd stage (16.1-15.2 Ma) was marked by fissure eruptions of highly evolved tholeiitic lavas (icelandites) along the length of the eruptive axis. Caldera forming 
eruptions of rhyolitic lavas and rhyolitic ash-flow tuffs from eruptive centers including the Littlefield Rhyolite, Dinner Creek Tuff, and Lake Owyhee Volcanic Field along the central and southern extents of the axis comprised stage 3 (15.5-14.7 Ma) of volcanic activity. In stage 4 (14.7-13.7 Ma), fissure eruptions produced olivine basalts along the length of the eruptive axis. Stage 5 (13.5-10.0 Ma) in the characterized by the eruption of calc-alkaline basaltic andesite, andesite, and dacite lavas along the length of the eruptive axis. Finally, stage 6 (7-1 Ma) was defined by small volume alkalic eruptions along the length of the LEOA (Ferns and McClaughry, 2013).

\section{ICELANDITE DISTRIBUTION}

Icelandites can be found in both the northern and southern sections of the La GrandeOwyhee eruptive axis (Figure 1). In the northern end of the eruptive axis the icelandite lavas form a geochemically distinct unit known as the Fiddler's Hell member and can be found on top of the Grande Ronde basalts on the west side of the La Grande graben. Bailey (1990) reported several analyses indicating that Fiddlers Hell lavas also form isolated erosional remnants atop pre-Tertiary basement rocks east of the Baker graben. Lavas with similar icelanditic compositions to Fiddlers Hell can be found near Indian Rock on Mt Emily just west of La Grande as well as to the north and south of Ironside Mountain. In the southern part of the La Grande-Owyhee eruptive axis, icelandite-type lavas have been recorded as part of the Hunter Creek Basalt by Ferns and McClaughry (2013) and Camp et al. (2003). Iron-rich andesite and basaltic andesite lavas are also exposed on the east, near the Oregon-Idaho border. Zimmerman (1991) described a succession at Indian Head Mountain in Washington County, Idaho, wherein flows of 
icelandite lavas are separated from the Grande Ronde Basalt lavas by a dacitic ash-flow tuff (Ferns and McClaughry, 2013). Zimmerman described the evolved (icelandite) flows as averaging up to 20 meters in thickness with flows being typically fine grained, aphyric and comprised of plagioclase, augite, spinel, and glass. The geochemistry of the icelanditic flows is said to be distinguished from local Grande Ronde flows by their slightly more evolved nature which is higher in $\mathrm{SiO}_{2}$ and $\mathrm{K}_{2} \mathrm{O}$ and lower in $\mathrm{MgO}$ and $\mathrm{CaO}$. This was the status of knowledge on the compositions and distribution of icelandites (as compositionally defined above) before MS thesis work by Cruz (2017), Webb (2017), and this study. 


\section{Methods}

SAMPLE COLLECTION

Samples for this study were collected during fieldwork in summer of 2017 (Figure 4).

The field area for this study covers an area of roughly 17,000 sq. miles from Pendleton in the northwest corner to Jordan Valley in the southeast corner. The primary focus in the northern half of the field area, which contains the La Grande graben and the Baker graben, was to resample at 29 locations that had been previously mapped and to further investigate the areas around the sample locations to verify the previously mapped extents of icelandite units. For icelandites of the southern field area, 25 samples and associated outcrop locations for this study came from prior MS thesis work by Cruz (2017), Webb (2017), and unpublished data from my advisor, Dr. Martin Streck, acquired since 2012 . These 25 samples were added to 11 new samples that were collected during this study.

The samples that were collected during fieldwork for this study were given ID's denoting the initials of the collector (MAC) followed by the year and the sample number. For locations with more than one sample, the sample number included a letter identifier as well. While in the field, characteristics of the units from which samples were collected were recorded, major lithological characteristics of overlying and underlying units at sample locations when visible were noted, as well as GPS coordinates of the locations using the Avenza Maps app for iPhone and a Garmin eTrex handheld GPS unit. 


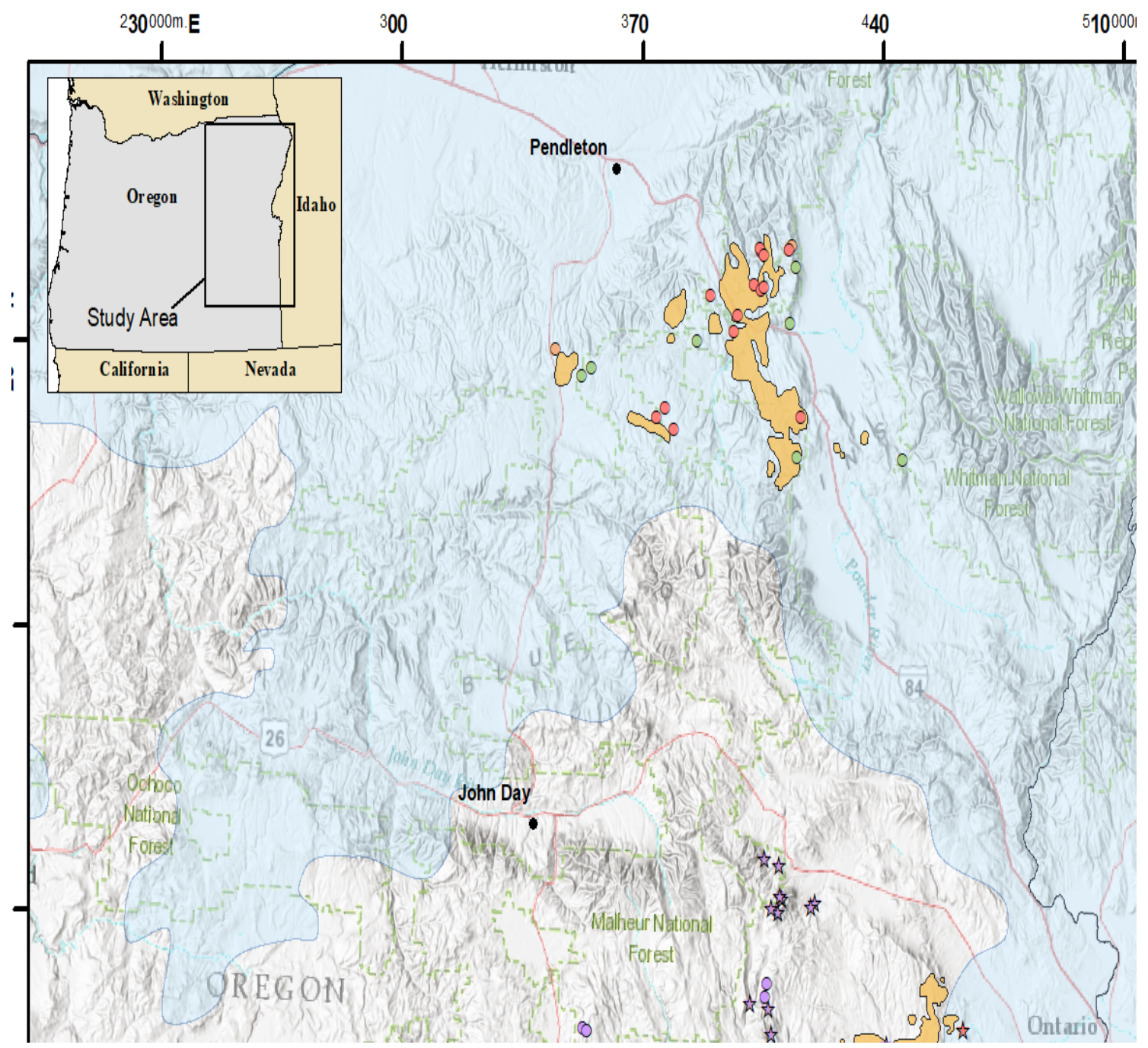

Figure 4. Map of study area in eastern Oregon. Mapped extent of icelandites prior to 2017 fieldwork is shown in orange shade. CRBG extent is shown in blue shade. Base map from ArcGIS online library.

\section{PREPARATION AND GEOCHEMICAL ANALYSIS}

Thirty-one samples were selected from the 42 samples collected during this study for bulk rock analysis. The samples were chipped using a chipmunk rock crusher in the facilities at Portland State University to uniform size fraction of $\sim 0.5 \mathrm{~cm}$ and then handpicked to remove weathering rinds, secondary mineralization in vesicles and other alteration products. The samples were then taken to the Peter Hooper GeoAnalytical lab at Washington State University in Pullman Washington. There the samples underwent 
further preparation where the rock chips were broken down into a powder, $3.5 \mathrm{~g}$ of the powder was mixed with $7.0 \mathrm{~g}$ dilithium tetroborate flux and fused into glass beads for XRF analysis. For ICP-MS analysis $250 \mathrm{mg}$ of the sample and flux powder mixture for the samples were dissolved in acid solutions. The glass beads and rock-acid solutions were then analyzed for major and trace element elemental concentrations using the Thermal -ARL automated x-ray fluorescence spectrometer (XRF) for the glass beads and Agilent inductively coupled plasma mass spectrometer (ICP-MS) for the rock-acid solutions. Data collected from the XRF and ICP-MS analysis can be found in the appendices (see Appendix A).

PETROGRAPHIC AND SEM ANALYSIS

Petrographic analysis was completed at Portland State University using a Zeiss

Primotech polarized light microscope to analyze samples of this study. Detailed descriptions of the thin sections including textures, phenocryts size/shape, groundmass, alteration products, mineral assemblages, and proportion of phenocrysts were recorded and can be found in Appendix F. Five of the thin sections were carbon coated for SEM analysis at Portland State University's Center for Electron Microscopy and Nanofabrication (CEMN). The SEM analysis was conducted on the ZEISS Sigma VP FEG SEM using back-scatter electron (BSE) imaging and energy-dispersive $\mathrm{x}$-ray spectroscopy (EDS) on specific minerals within the sections to determine their composition. The sites that were selected for back-scatter electron imaging BSE and electron dispersive spectroscopy (EDS) were the largest unaltered fracture less plagioclase and clinopyroxene phenocrysts in the selected sections. A 5-10 microphenocrysts of 
plagioclase and pyroxene were also selected from each thin section for EDS. The images and EDS spectra were then processed using Oxford's Aztec software at Portland State University. Data for plagioclase and clinopyroxenes analyzed using EDS were plotted into ternary phase diagrams.

\section{GEOCHEMICAL MODELING}

Two models were set up, the first utilizing only fractional crystallization (Rayleigh fractionation) to establish if icelandites could be generated from fractional crystallization alone and the second model using magma mixing to evaluate if icelandites could be plausibly generated from magma mixing between mid-Miocene felsic magmas and a Grande Ronde type end member.

Fractional crystallization was used to assess the feasibility of producing icelandites via Rayleigh fractionation from a parent magma (see below). Equation 2 is the rearranged equation for fractional (Rayleigh) crystallization to solve for the daughter magma. In it, the concentration $C^{\prime}$ of a solid phase in the daughter magma, is a function of the concentration of the solid phase in the parent magma, $C^{0}$, the bulk partition coefficient $D$, and the melt fraction remaining $F$.

$$
C_{l}=F^{D-1} \times C_{0}
$$

In order to accurately model the formation of icelandites, partition coefficients (Dvalues) were carefully selected from published sources of tholeiitic basalts and andesites based on the identified mineral phases of the samples. Partition coefficients $\left(K_{D}\right)$ were interpolated when no published values could be identified ( $K_{D}$ values and sources can be found in Appendix C, Table 1). The missing values were interpolated based on the 
surrounding $K_{D}$ values. A bulk partition coefficient was calculated for individual elements based on the partition coefficient for individual phases using Equation 1, where $\bar{D}$, the bulk partition coefficient for any element, $i$, is determined from the weight fraction $X$ of a solid mineral phase, $s$, and $D_{i}^{S}$, the partition coefficient for an element, $i$, in a solid mineral phase.

$$
\bar{D}_{\imath}=\sum X_{S} D_{i}^{S}
$$

Observed modal mineral proportions determined of icelandites and basaltic andesites of the Grande Ronde/Hunter Creek Basalt along with the volatile free re-normalized CIPW norms calculated from the bulk rock analyses were used to determine mineral proportions to calculate bulk partition coefficients for the models. The parent magmas were estimated by linearly tracing back on chemical plots from the icelandite to Grande Ronde and Hunter Creek Basalt to identify the Grande Ronde/Hunter Creek Basalt samples with the most plausible major and trace elemental concentrations. It was deduced early on that the two groups of icelandites very likely came from two slightly different parent magma bodies. The elemental concentrations of the two parent magmas that were used for modeling reflect those subtle differences. The trace element concentrations were calculated for $0 \%$ to $40 \%$ fractionation in $2 \%$ increments using the partition coefficients that can be found in Appendix $C$. The calculated values for major and trace elements were plotted in Harker diagrams versus $\mathrm{SiO}_{2}$ and compared to the averaged values of the icelandites groups. Trace element values and REE were plotted in spider diagrams that were also compared to the averaged icelandites group values. The 
spider diagrams of the resulting trace element and REE calculated values were normalized using the primitive mantle of Sun and McDonough (1989) and C1 chondrite normalizing values of McDonough and Sun (1995). The calculated values and diagrams for Rayleigh crystallization can be found in Appendix D

The second model utilized Equation 3, which is a standard mass balance equation, to determine if an icelanditic magma would result from mixing of a Grande Ronde type endmember with a rhyolitic endmember. The rhyolitic endmembers used in the model are the four units of the Dinner Creek Tuff as well as the upper and lower Littlefield rhyolite,

$$
C_{m}=C_{a} X_{a}+C_{b}\left(1-X_{a}\right)
$$

In the standard mass balance equation for mixing between two magmas, the concentration of each element in the mixed magma is the sum of the elemental concentration $\left(C_{a}\right)$ in the mafic endmember, $\left(X_{a}\right)$ is the mass fraction of the mafic endmember in the mix, and $\left(C_{b}\right)$ is the elemental concentration of the felsic endmember in the mixture. The mixed magma was calculated for $0 \%$ to $50 \%$ mix in increments of $5 \%$ for all felsic endmembers except for Dinner Creek Tuff Unit 4, which was calculated to 70\%. The resulting trace element values of the mixed magma were normalized to the primitive mantle of Sun and McDonough (1989) and C1 chondrite values of McDonough and Sun (1995). The initial and calculated values for the binary mixing model can be found in Appendix E. 


\section{Results}

LITHOLOGY

The rocks of the Fiddlers Hell unit, which are found in the vicinity of the La Grande and Baker grabens (Figure 5) are tholeiitic basaltic andesites and icelandites. These rocks range in color from bluish gray to dark gray to almost black in color. The Fiddlers Hell flows are generally fine-grained and range from aphyric in the lower-most flows to sparsely (1-3\%) plagioclase phyric in capping flows. Samples that were collected from ridge top locations in and around the La Grande and Baker grabens had reddish brown weathering rinds of up to $\sim 1 \mathrm{~cm}$ in thickness covering the exterior. The flows themselves were either platy or hackly and formed large slightly rounded blocks when found in outcrops. 


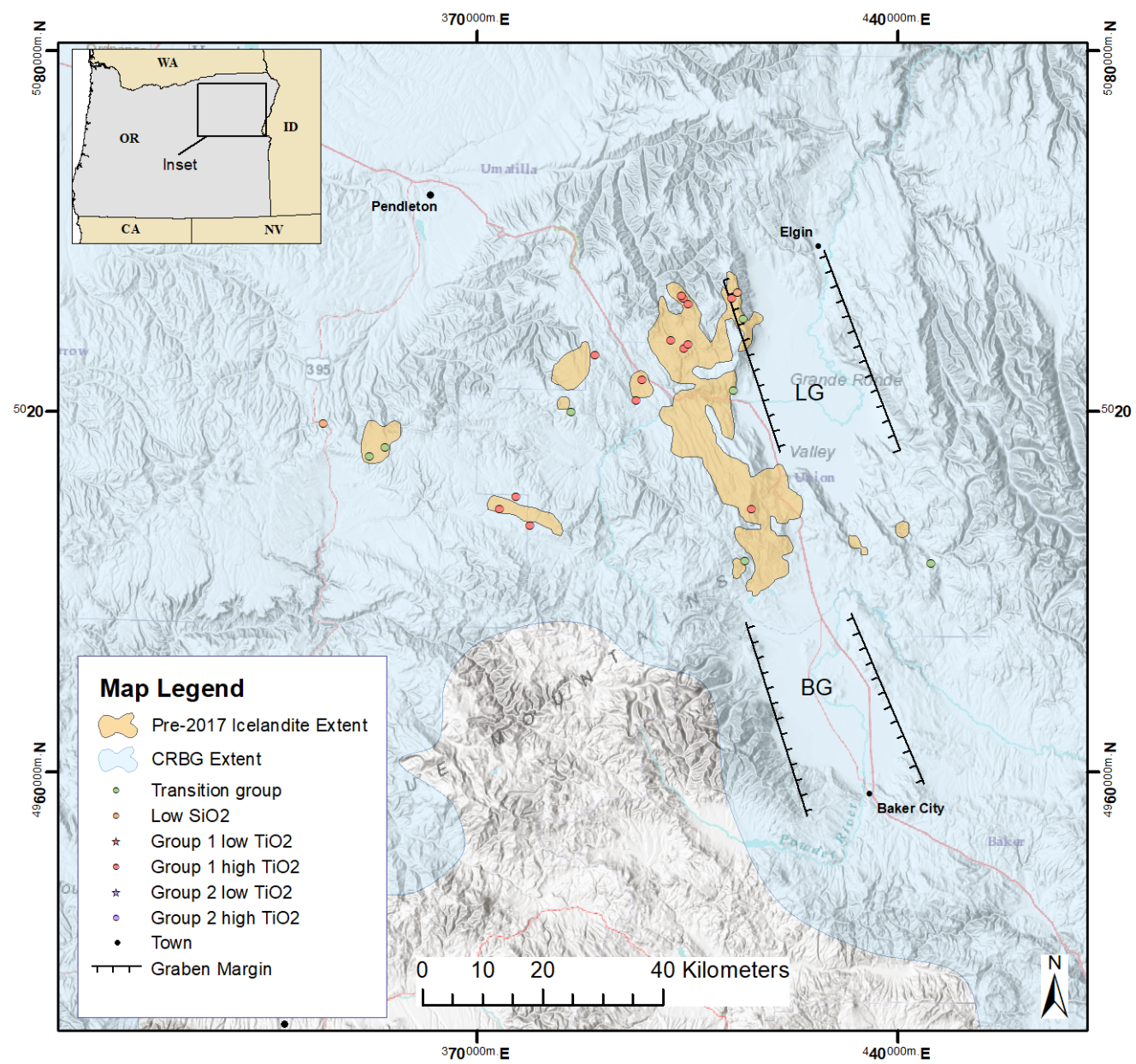

Figure 5. Map of northern half of study area. Regional features are as follows: WA-Washington; OROregon; ID-Idaho; LG - La Grande graben; BG-Baker graben; Mapped extent of icelandites prior to 2017 fieldwork is shown in orange shade. CRBG extent is shown in blue shade. Base map from ArcGIS online library.

In the Malheur Gorge (Figure 6), icelandites occur as part of lava flows of the Hunter Creek Basalt unit and as the icelandite of Alder Creek mapped by Webb (2017). The flows of the 16.1 Ma Hunter Creek Basalt overlie the 16.16-15 Ma Dinner Creek Tuff and intercalated between lower and upper Littlefield Rhyolite in the Malheur River Gorge (Webb et al., 2018). In the southern stratigraphic transect of Alder Creek canyon, Webb (2017) describes the occurrence of an icelandite lava ( $62 \mathrm{wt} \% \mathrm{SiO}_{2}$ ) overlying the Dinner Creek Tuff. This icelandite lava forms steep talus dominated slopes that 
obscure outcrops. The icelandite is itself overlain by a thin lens of moderately-welded dacitic tuff which directly underlies the glassy base of the upper Littlefield rhyolite. This icelandite was previously mapped as part of the Hunter Creek basalt on the basis of lithological characteristics and stratigraphy (Kittleman et al., 1967; Evans and Binger, 1999c) and thus is stratigraphically equivalent to the Hunter Creek Basalt (Webb, 2017). Icelanditic flows are generally indistinguishable from the bulk of the Hunter Creek Basalt that is more mafic, basaltic andesite lavas. All are gray to dark gray in color and very fine grained. These rocks are generally aphyric to very sparsely plagioclase phyric, nearly all phenocrysts are virtually undetectable with the unaided eye. Webb (2017) describes the icelandite of Alder Creek as being lithologically similar and petrogenetically linked to the Hunter Creek are geochemically distinct from the other icelandites observed in this study. 


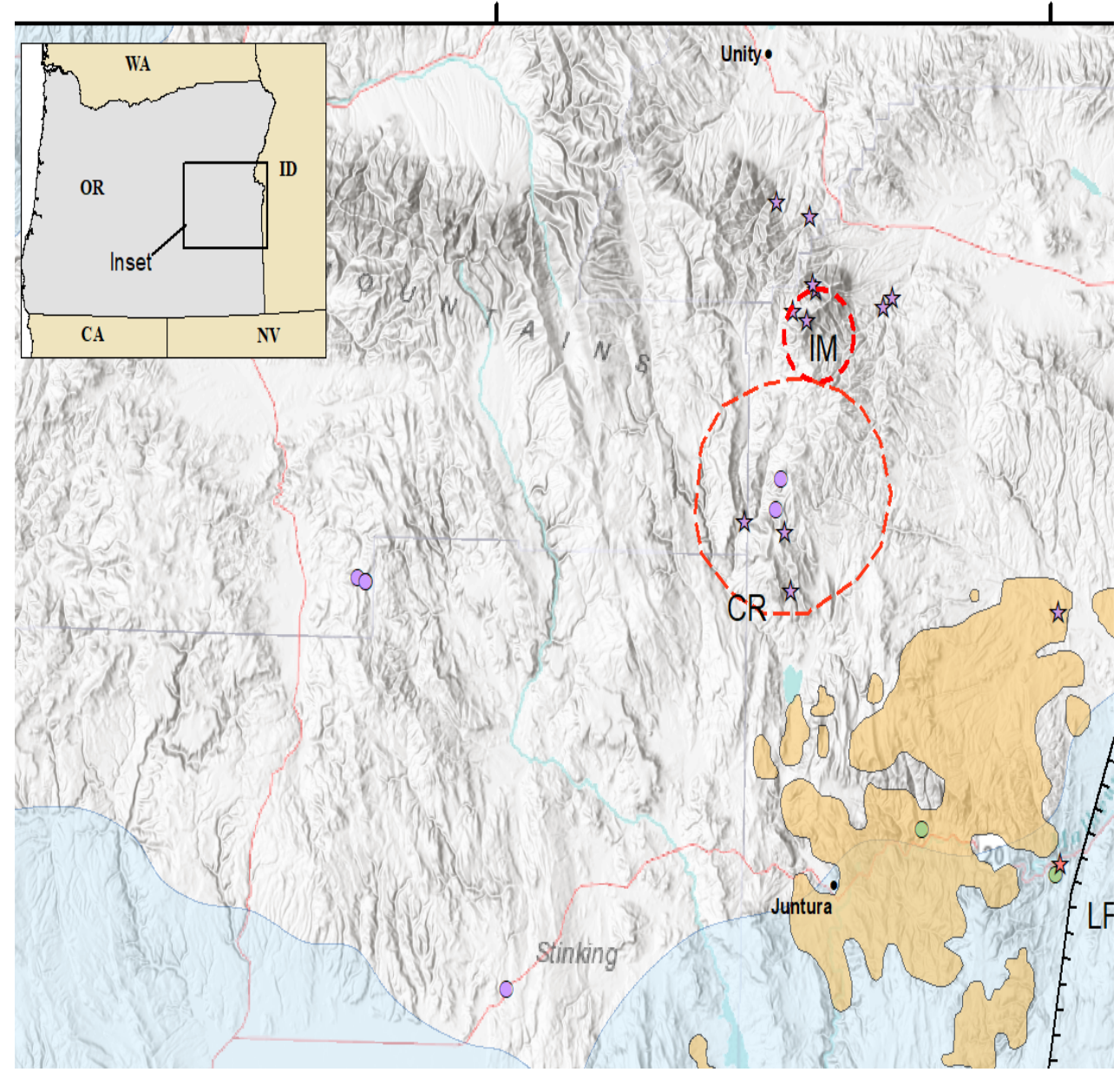

Figure 6. Map of Southern half of study area. Regional features are as follows: WA-Washington; OROregon; ID-Idaho; OIG-Oregon-Idaho graben; CR-Castle Rock Caldera; SM-Strawberry Volcanics; IM-Ironside Mountain; LFR-Littlefield Rhyolite; CM-Rhyolite of Cottonwood Mountain; Mapped extent of icelandites prior to 2017 fieldwork is shown in orange shade. CRBG extent is shown in blue shade. Base map from ArcGIS online library.

In the field area of Cruz (2017) between Castle Rock in the south and Ironside Mountain in the north (Figure 6), samples of icelandites are found as sills, dikes, and lava flows.

Some of these icelandites were emplaced along with aphyric basaltic andesites after the eruption of Dinner Creek Tuff eruptive units 1 and 2, which they intrude into. They are also known to overlie the intra-caldera tuffs and caldera floor sediments of the Castle Rock Caldera and Ironside Mountain Caldera. Cruz identifies six icelandites in his work through geochemical analysis and petrography, which has been expanded to include 
MC-45-16, MC-69-16, MC-106-16, MC-15-16, and MC-98-16 using geochemical analysis performed during this study.

\section{PETROGRAPHY}

A subset of 7 samples were selected from the 47 samples that were newly collected during this study and six samples from the work of previous students. The samples chosen for petrographic analysis were determined based on bulk geochemistry, geographic location, and freshness of the sample. A complete table of the petrographic analysis that includes texture, mineral phases, and mineral characteristics can be found in Appendix F. The samples overall are fine grained aphanitic, with matrix material size of less than or equal to $50 \mu \mathrm{m}$, with the matrix being comprised of plagioclase feldspar, clinopyroxene, ilmenite, and magnetite, with sparse altered olivine. Samples are generally aphyric to plagioclase phyric and sparsely pyroxene phyric. When phenocrysts are present, they are small, mostly ranging in size from $70 \mu \mathrm{m}$ to $500 \mu \mathrm{m}$. Larger phenocrysts are rare, but a few have been found in select thin sections with a size of up to $1.7 \mathrm{~mm}$. The samples from the Fiddlers Hell unit (MAC-17-04a, MAC-17-06, MAC-1716, MAC-17-18, and MAC-17-29) contain between 1-3\% phenocrysts, while the sample MS-12-34 (Hunter Creek at Neal Hot Springs) has 1\% phenocrysts and MC-94-16 (icelandite from east of Ironside Mountain) contains $<1 \%$ phenocrysts. The phenocrysts are plagioclase feldspar and clinopyroxene (Figure 9-10). Twinning of plagioclase is common and is a combination of simple and/or poly-synthetic twinning in these sections. MAC-17-04a (Figure 7) and MAC-17-06 (Figure 8) are the only sections to exhibit twinning in clinopyroxene of the Fiddlers Hell sample. 

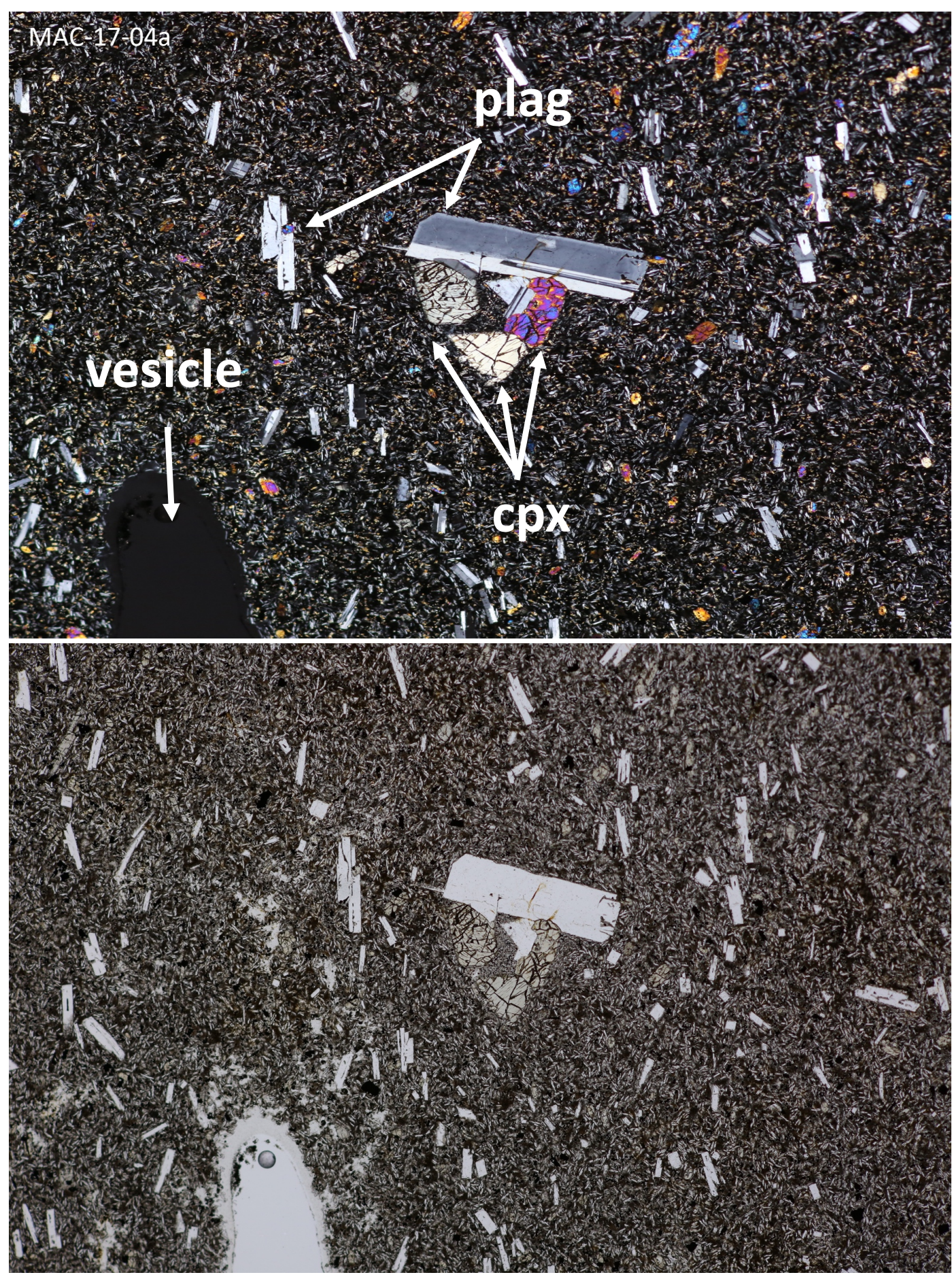

Figure 7. Photomicrograph of clinopyroxene and plagioclase feldspar phenocrysts in plain polarized light (PPL) and cross-polarized light (XPL) for sample MAC-17-04a. The field of view for both images is $9 \mathrm{~mm}$ in width. Images taken under 50x magnification. Thin sections images courtesy of Dr. Daniel Heaton of Oregon State University. 

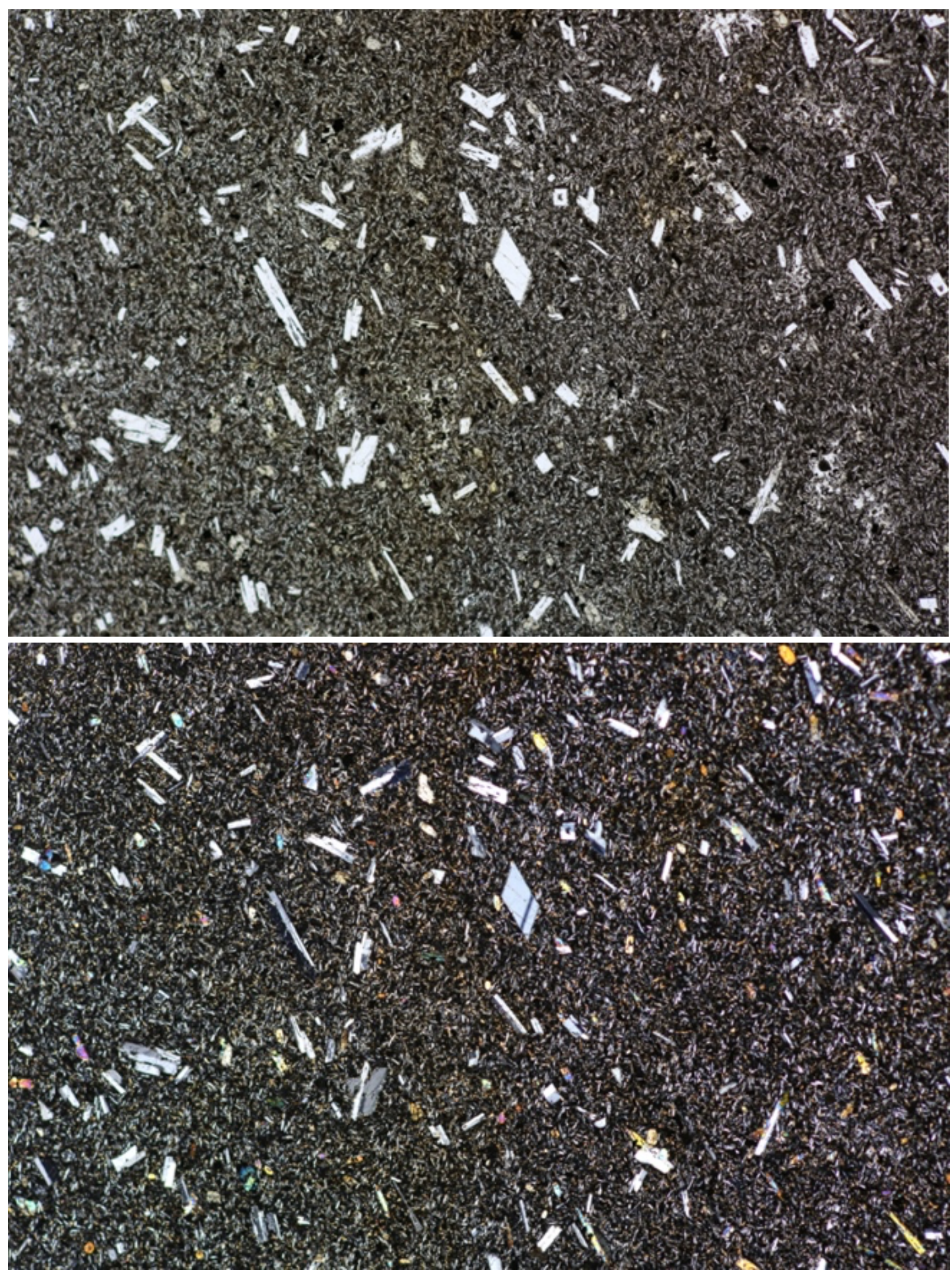

Figure 8. Photomicrograph of clinopyroxene and plagioclase feldspar phenocrysts in plain polarized light (PPL) and cross-polarized light (XPL) for sample MAC-17-06. The field of view for both images is $9 \mathrm{~mm}$ in width. Images taken under 50x magnification. Thin sections images courtesy of Dr. Daniel Heaton of Oregon State University. 
MS-94-16 (Figure 9) has the most fine-grained groundmass within the thin sections. This sample contains 5-7 phenocrysts, of which, one is a plagioclase phenocryst with an embayed crystal that was possibly formed at an earlier time in the evolution of the magma. The crystal appears to have been in the process of being resorbed into the magma at the time of eruption. Both the phenocryst and margin of the smaller embayed crystal appear to have a narrow reaction rim along which groundmass crystals have aligned. The reaction rim with aligned iron oxide microlites is an indicator of disequilibrium within the magma during crystallization. The section of Hunter Creek Basalt from Neal Hot springs, MS-12-34 (see Appendix F), contains sparse phenocrysts of plagioclase feldspar and clinopyroxene. Both the plagioclase phenocrysts and the pyroxene phenocrysts range from moderately anhedral to euhedral. Two pyroxenes show textures that are consistent with being actively resorbed. The texture of the sample is aphanitic, and the micro-phenocryst content is between $1-2 \%$ at most. The other most abundant materials in the thin sections are alteration products.

The icelandites of Alder Creek, BW-14-37A and BW-14-37B, are overall petrographically similar to typical Hunter Creek Basalt lavas, having aphanitic texture containing groundmass feldspar, magnetite, clinopyroxene, and interstitial glass, but they contain a few relatively large, phenocrysts of tabular feldspars (Webb, 2017).

MC-106-16 consists of mostly microlites consisting of plagioclase lathes, opaque minerals, and tiny crystals with higher interference colors that are likely pyroxenes, 


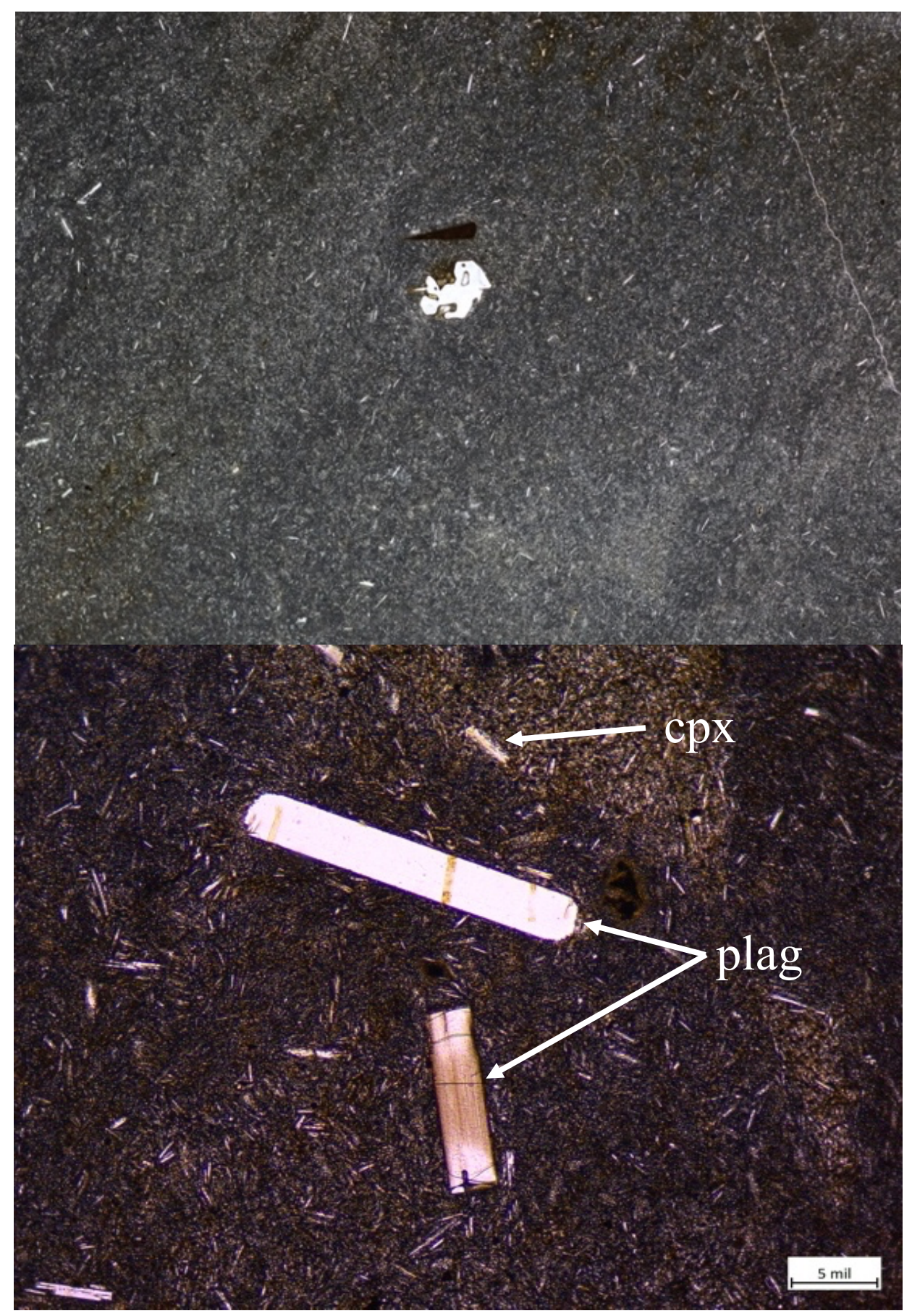

Figure 9. Photomicrograph of clinopyroxene and plagioclase feldspar phenocrysts in plain polarized light (PPL) and cross-polarized light (XPL) for sample MAC-17-06. The field of view for both images is $9 \mathrm{~mm}$ in width. Images taken under 50x magnification. Thin sections images courtesy of Dr. Daniel Heaton of Oregon State University.

although they are too small to properly analyze even under highest magnification. Only four phenocrysts of simply twinned plagioclase can be observed in this sample. MC-98- 
16 comes from an icelandite dike on the west flank of Ironside Mountain. Like MC-10616 , this sample has a texture with mostly microlites and with rare plagioclase phenocrysts. MC-15-16 is also aphyric under the petrographic microscope, even lacking sparse plagioclase phenocrysts that occur in MC-106-16 and MC-98-16. All three of these samples occur stratigraphically above the Dinner Creek Tuff unit 1, with MC-15-16 occurring within the Castle Rock caldera, and MC-98-16 and MC- 106-16 occurring at the Ironside Mountain caldera. The MC-101-16 sample comes from the western flank of Ironside Mountain. These samples were taken from aphyric icelandite lava intrusive into altered Dinner Creek Tuff unit 2.

\section{WHOLE ROCK GEOCHEMISTRY}

The 47 icelandite samples analyzed for this study range in composition from basaltic andesite to dacite in a total alkali silica (TAS) diagram (Figure 11). The most mafic sample, MAC-17-15 is a basaltic andesite with $\mathrm{SiO}_{2}$ content of $\sim 54 \%$ and the most felsic sample, BW-14-37A, is a dacite with $\sim 63 \% \mathrm{SiO}_{2}$. The samples with the highest $\mathrm{SiO}_{2}$ content are samples of the icelandite of Alder Creek located in the southern part of the Namorf quadrangle area in the Malheur River Gorge and the icelandites of the Castle Rock caldera area. The samples with the lowest total alkali content of this study are located near Castle Rock Caldera. These two samples have been classified as a pumice lapilli tuff by Cruz (2017). Published icelandite data shown in geochemical plots along with data of this study were compiled from Carlson and Hart (1987), Bailey (1989), Hooper and Swanson (1990), Hooper and Hawkesworth (1993), Hooper (2000), Hooper 
et al. (2002) Lees (1994), Binger (1997), Reidel (1998), Reidel and Tolan (2013), Camp et al. (2003), Brueseke and Hart (2007), and Ferns et al., (2010).

Based on data of this study, the icelandites are divided into two primary groups based on the concentrations of $\mathrm{Al}_{2} \mathrm{O}_{3}$ and selected trace elements (Tables 1 and 2; Figures 1013 and 17-23). Group 1 has lower concentrations of $\mathrm{Al}_{2} \mathrm{O}_{3}$ compared to the samples of Group 2. Group 1 is more enriched in the selected trace elements and REE while Group 2 is depleted in those same elements and REE. The division of the two main groups into secondary high and low $\mathrm{TiO}_{2}$ groups is based on the large gaps between the samples within Groups 1 and 2. This can be seen in both the tables as well as the plot of $\mathrm{TiO}_{2}$ versus $\mathrm{SiO}_{2}$ (Figure 12). 


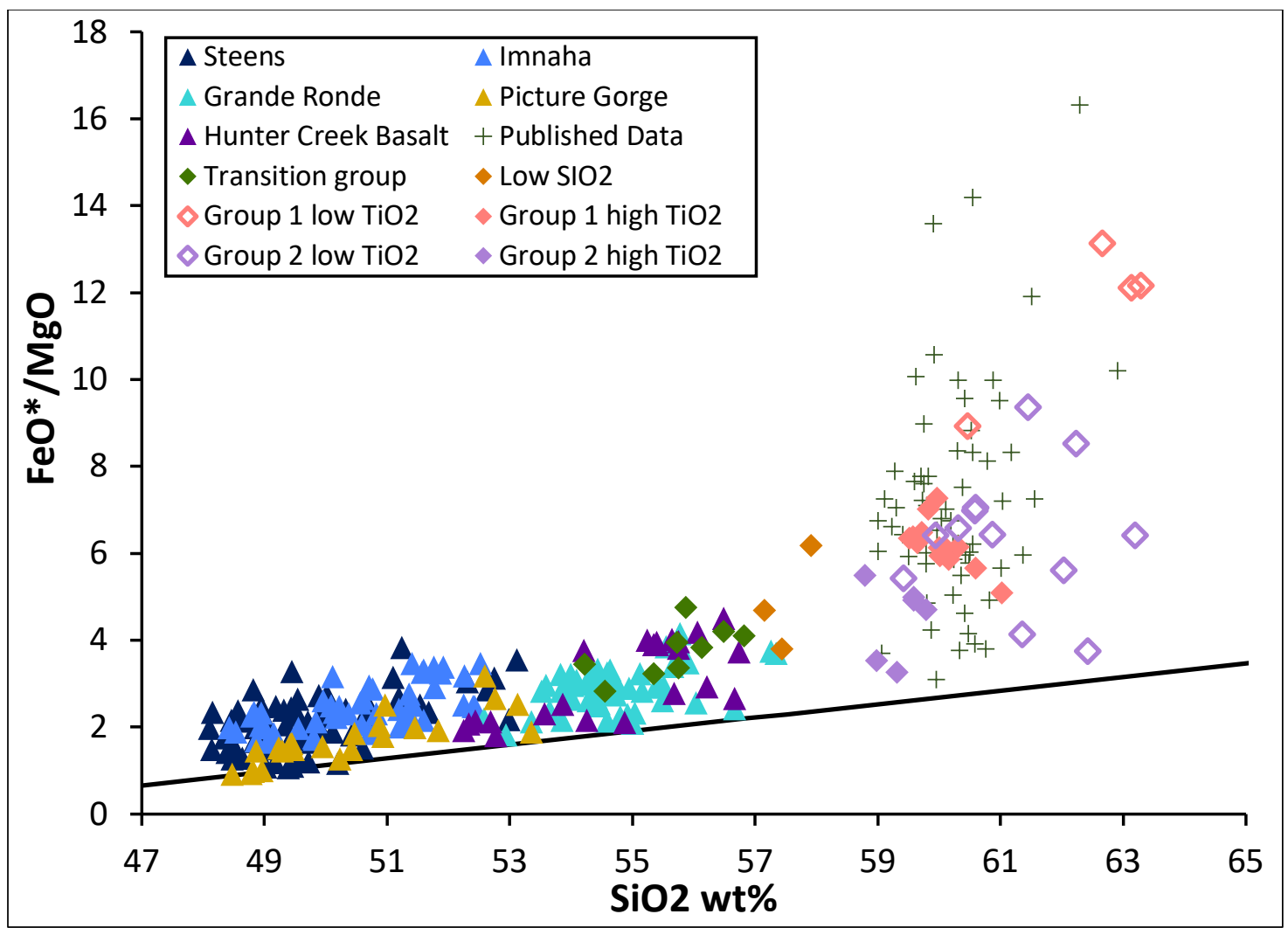

Figure 10. Plot of $\mathrm{FeO} / \mathrm{MgO}$ ratio versus silica content CRBG main phase members, Basalt of Malheur Gorge, Picture Gorge Basalt, Hunter Creek Basalt, icelandite groups of this study and previously published icelandites of CRBG from Carlson and Hart (1987), Bailey (1989), Hooper and Swanson (1990), Hooper and Hawkesworth (1993), Hooper (2000), Hooper et al. (2002), Lees (1994), Binger (1997), Reidel (1998), Reidel and Tolan (2013), Camp et al. (2003), Brueseke and Hart (2007), and Ferns et al., (2010).

Table 1. Ranges for major element concentrations in icelanditic rocks. Data for this table can be found in Appendix A.

\begin{tabular}{|c|c|c|c|c|c|c|}
\hline Group & Transition & Low $\mathrm{SiO}_{2}$ & $\begin{array}{l}\text { Group } 1 \\
\text { low } \mathrm{TiO}_{2}\end{array}$ & $\begin{array}{c}\text { Group } 1 \\
\text { High TiO }_{2}\end{array}$ & $\begin{array}{l}\text { Group } 2 \\
\text { low } \mathrm{TiO}_{2}\end{array}$ & $\begin{array}{c}\text { Group } 2 \\
\mathrm{High} \mathrm{TiO}_{2}\end{array}$ \\
\hline $\mathrm{SiO2}$ & $54.22-56.81$ & $57.15-57.91$ & $60.46-63.28$ & $59.51-61.02$ & $59.42-63.20$ & $58.79-59.78$ \\
\hline $\mathrm{TiO}_{2}$ & $2.14-2.41$ & $1.84-2.39$ & $1.19-1.56$ & $1.95-2.01$ & $1.08-1.50$ & $1.77-1.95$ \\
\hline $\mathrm{Al}_{2} \mathrm{O}_{3}$ & $13.32-14.54$ & $13.41-16.09$ & $12.87-13.54$ & $13.13-13.56$ & $14.08-15.45$ & $14.96-15.47$ \\
\hline $\mathrm{FeO}^{*}$ & $11.21-13.35$ & $9.36-11.38$ & $9.84-11.76$ & $8.84-11.25$ & $7.81-10.54$ & $8.17-9.61$ \\
\hline $\mathrm{MnO}$ & $0.17-0.23$ & $0.19-0.53$ & $0.20-0.26$ & $0.21-0.28$ & $0.13-0.21$ & $0.15-0.21$ \\
\hline MgO & $2.73-4.03$ & $1.51-2.86$ & $0.75-1.32$ & $1.55-1.75$ & $1.06-2.76$ & $1.75-2.52$ \\
\hline $\mathrm{CaO}$ & $6.15-8.18$ & $5.77-6.47$ & $3.99-5.04$ & $4.96-5.43$ & $4.35-5.51$ & $5.10-5.96$ \\
\hline $\mathrm{Na}_{2} \mathrm{O}$ & $3.04-3.72$ & $3.07-4.32$ & $3.49-4.05$ & $3.36-3.80$ & $1.49-4.22$ & $3.69-4.30$ \\
\hline $\mathrm{K}_{2} \mathrm{O}$ & $1.34-1.99$ & $1.40-2.40$ & $2.65-3.31$ & $2.27-2.91$ & $1.45-2.70$ & $1.72-2.23$ \\
\hline $\mathrm{P}_{2} \mathrm{O}_{5}$ & $0.38-0.61$ & $0.56-1.62$ & 0.27-0.59 & $0.78-0.82$ & $0.27-0.66$ & 0.77-1.12 \\
\hline
\end{tabular}


Table 2. Ranges for selected trace element and REE concentrations in icelanditic rocks. Data used for this table can be found in Appendix A.

\begin{tabular}{|c|c|c|c|c|c|c|}
\hline $\begin{array}{c}\text { Element } \\
\text { (ppm) }\end{array}$ & Transition & Low $\mathrm{SiO}_{2}$ & $\begin{array}{c}\text { Group 1 Low } \\
\mathrm{TiO}_{2}\end{array}$ & $\begin{array}{c}\text { Group 1 } \\
\text { High TiO }_{2}\end{array}$ & $\begin{array}{l}\text { Group 2 } \\
\text { Low } \mathrm{TiO}_{2}\end{array}$ & 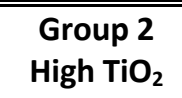 \\
\hline $\mathrm{Ba}$ & $559-942$ & $691-1148$ & $1091-1204$ & $931-1403$ & 765-1039 & $710-1094$ \\
\hline Th & 3.99-6.31 & $4.2-6.8$ & $8.3-9.8$ & $7.9-8.3$ & $3.0-5.4$ & $3.2-4.0$ \\
\hline $\mathrm{Nb}$ & $11.7-15$ & $13.0-16.5$ & $20.1-23.4$ & $17.2-18.0$ & $8.5-11.3$ & $11.0-13.9$ \\
\hline$Y$ & $35.4-47$ & $38.5-52.5$ & $58.2-67.7$ & 55.1-63.2 & $43.2-52.2$ & $43.4-53.4$ \\
\hline $\mathrm{Hf}$ & 4.64-5.9 & $5.5-6.1$ & $7.7-9.2$ & 6.8-7.1 & $4.4-5.8$ & $5.0-5.2$ \\
\hline Ta & $0.75-0.99$ & $0.9-1.1$ & $1.3-1.5$ & $1.1-1.2$ & $0.6-0.7$ & $0.7-0.9$ \\
\hline $\mathbf{R b}$ & $34.5-49.5$ & $10.8-62.3$ & $78.7-83.8$ & $61.9-68.2$ & 28.7-60.0 & $33.6-44.7$ \\
\hline $\mathrm{Zr}$ & $171.3-222.5$ & $214.0-235.3$ & $289.8-356.3$ & 257.4-269.1 & $161.0-216.7$ & 190.9-202.1 \\
\hline La & $22.74-30.34$ & $24.3-34.7$ & $39.4-46.7$ & $37.9-43.2$ & $20.1-26.2$ & 25.1-29.6 \\
\hline $\mathrm{Ce}$ & 48.8-64.15 & $52.9-73.4$ & $83.1-96.5$ & $78.8-84.3$ & $38.3-53.4$ & $51.2-63.1$ \\
\hline $\operatorname{Pr}$ & $6.57-8.46$ & $7.0-9.8$ & $10.9-12.5$ & $10.4-11.4$ & $5.6-7.6$ & 7.8-8.9 \\
\hline Nd & $28.45-36.5$ & $30.2-41.5$ & $46.1-51.7$ & $44.1-48.7$ & $24.0-33.2$ & $34.1-38.3$ \\
\hline Sm & $6.96-8.93$ & 7.69 .8 & $11.2-12.1$ & 10.7-11.6 & $5.9-8.3$ & $8.5-9.2$ \\
\hline Eu & $2.12-2.72$ & 2.43 .0 & $3.4-3.5$ & $3.1-3.3$ & $1.6-2.3$ & $2.4-2.9$ \\
\hline Gd & $7.27-9.13$ & 7.79 .9 & $11.1-12.3$ & $10.8-11.9$ & $6.7-9.0$ & $8.5-9.7$ \\
\hline Tb & $1.20-1.52$ & 1.31 .6 & $1.9-2.0$ & $1.7-1.9$ & $1.2-1.5$ & $1.4-1.6$ \\
\hline Dy & 7.11-9.32 & 7.79 .7 & $11.3-12.4$ & $10.6-11.7$ & $8.0-9.6$ & $8.4-10.0$ \\
\hline Ho & $1.42-1.87$ & 1.62 .0 & $2.3-2.6$ & $2.2-2.4$ & $1.7-2.0$ & $1.7-2.1$ \\
\hline $\mathrm{Er}$ & $3.75-5.05$ & 4.25 .3 & $6.3-7.0$ & $5.8-6.6$ & $4.5-5.6$ & $4.5-5.5$ \\
\hline $\mathrm{Tm}$ & $0.53-0.72$ & 0.60 .8 & $0.9-1.0$ & $0.8-0.9$ & $0.7-0.8$ & $0.6-0.8$ \\
\hline $\mathrm{Yb}$ & $3.19-4.43$ & 3.64 .7 & $5.7-6.2$ & $5.0-5.6$ & $4.2-5.1$ & $3.9-4.9$ \\
\hline Lu & $0.5-0.72$ & $0.6-0.8$ & $0.9-1.0$ & $0.8-0.9$ & $0.7-0.8$ & $0.6-0.8$ \\
\hline
\end{tabular}




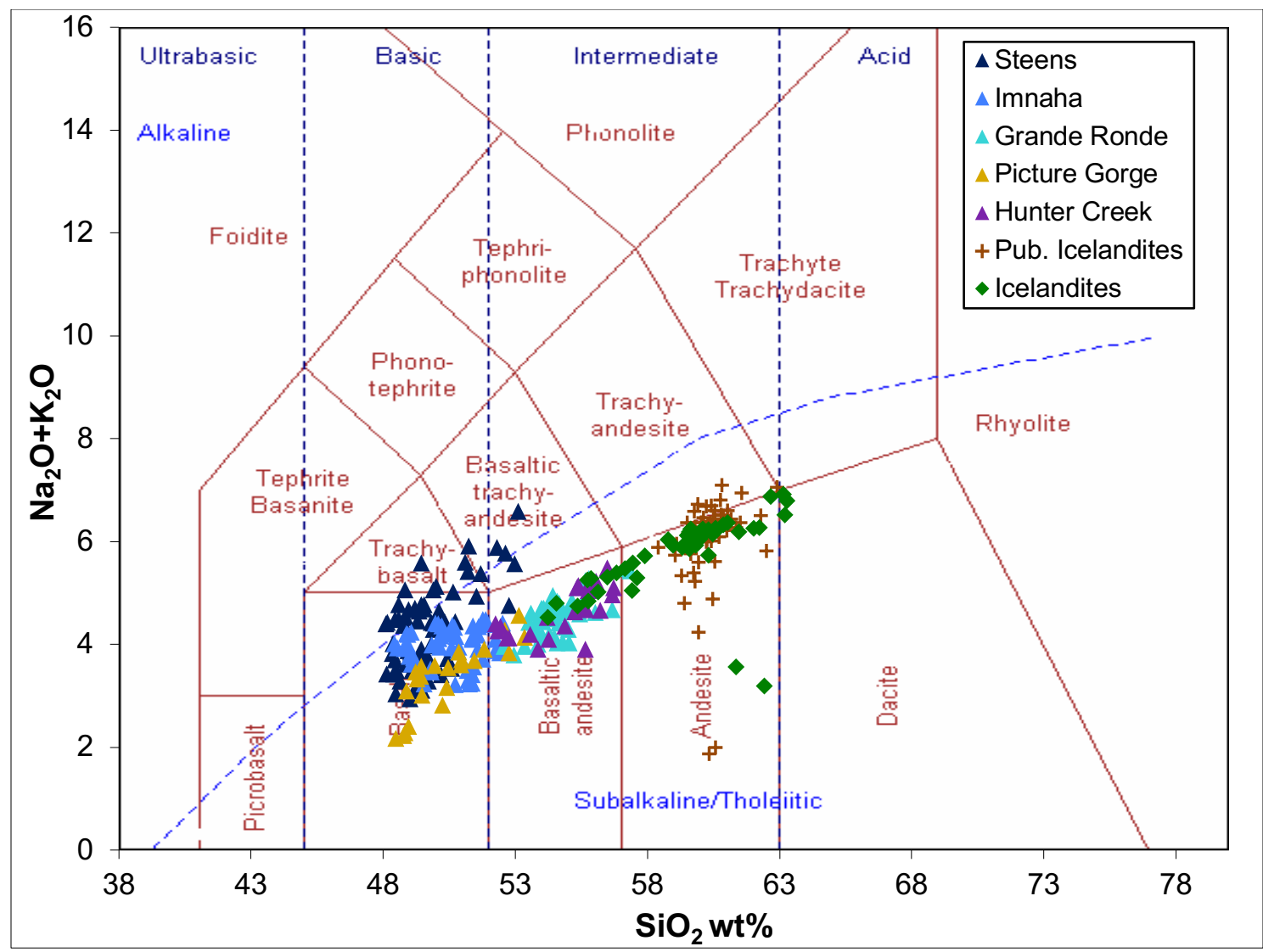

Figure 11. Total alkali versus silica content diagram (after Le Bas et al., 1986, Fig. 1) for main phase CRBG members, Picture Gorge Basalts, Basalt of Malheur Gorge, Hunter Creek Basalt, and icelandite units of this study. Analyses are from Carlson and Hart (1987), Bailey (1989), Hooper and Swanson (1990), Hooper and Hawkesworth (1993), Hooper (2000), Hooper et al. (2002) Lees (1994), Binger (1997), Reidel (1998), Reidel and Tolan (2013), Camp et al. (2003), Brueseke and Hart (2007), and Ferns et al., (2010). Data from this study used for plotting can be found in Appendix A.

With major elements, we see several differences between the icelandites of this study in comparison to the CRBG main phase members and Hunter Creek Basalt. A significant gap is observed in $\mathrm{SiO}_{2}$ with all major element oxides, $\mathrm{FeO} / \mathrm{MgO}$ and $\mathrm{Mg} \#$ continuing in general the trend (increasing or decreasing) of main phase CRBG units (Figure 10 and 12-13). Only two samples above the lower limit for icelandite silica content have a $\mathrm{TiO}_{2}$ content of over $2 \% \mathrm{wt}$, all remaining samples over $2 \%$ fall in the transition zone between 
basaltic andesite and icelandite. The only sample with an $\mathrm{Al}_{2} \mathrm{O}_{3}$ content of more than $16 \%$, is located in the Jump off Joe Mountain quadrangle.
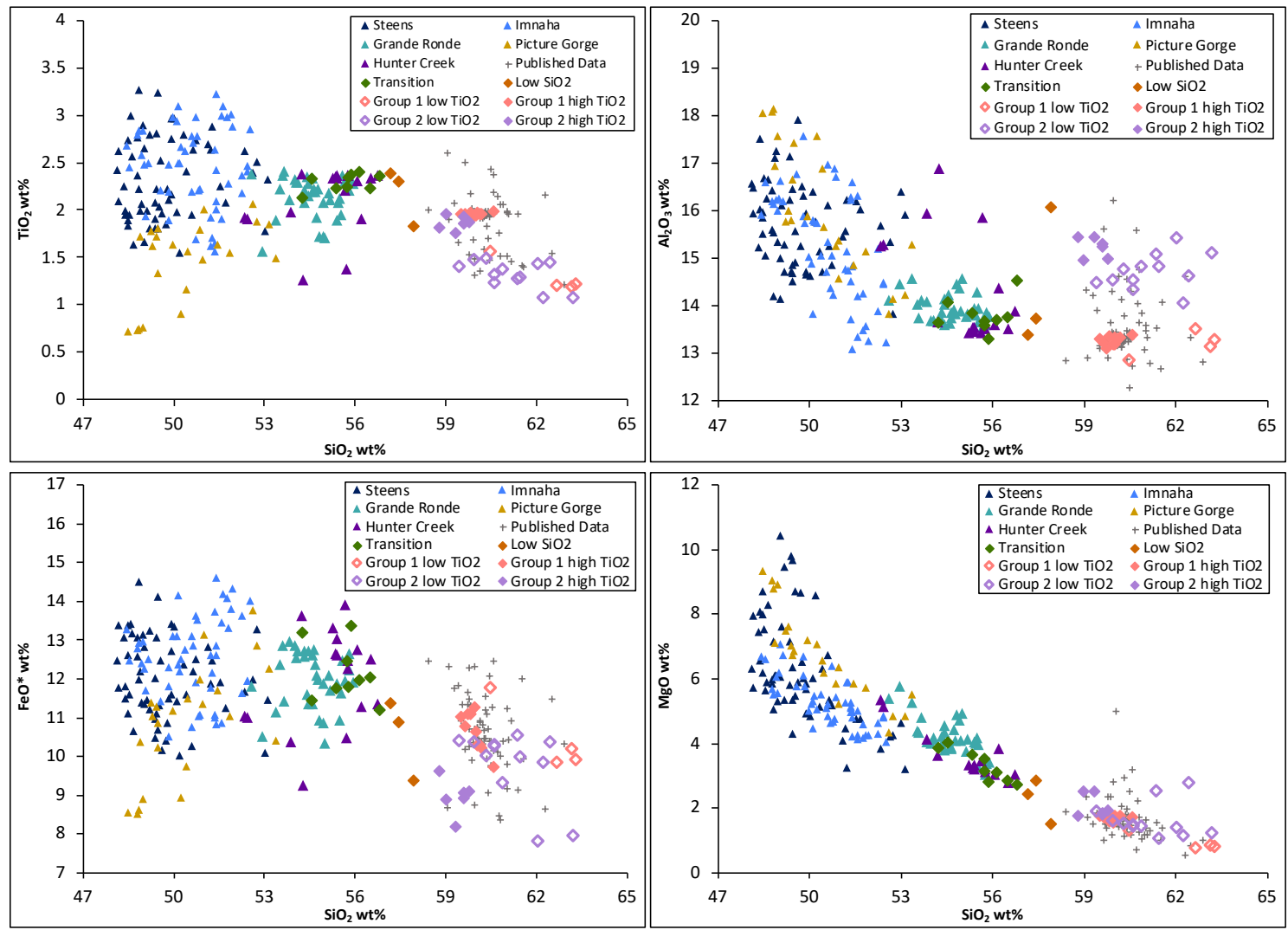

Figure 12. Major element $\mathrm{x}-\mathrm{y}$ plots for $\mathrm{TiO}_{2}, \mathrm{Al}_{2} \mathrm{O}_{3}, \mathrm{FeO}$, and $\mathrm{MgO}$ wt \% vs. $\mathrm{SiO}_{2}$ wt\% for main phase CRBG members, Hunter Creek Basalt, Picture Gorge Basalt, and icelandites of this study. Data used for these plots can be found in Appendix A.

Variations in incompatible element concentrations and $\mathrm{Al}_{2} \mathrm{O}_{3}$ allow to separate icelandite samples with $\mathrm{SiO}_{2}$ concentrations of $59 \mathrm{wt} . \%$ and higher into two main groups (Figures 12 and 16-23). Group 1 samples have distinctly higher concentrations of incompatible elements such as $\mathrm{Nb}, \mathrm{REE}$, and Th but lower $\mathrm{Al}_{2} \mathrm{O}_{3}$ than Group 2. Furthermore, based on a diagram of $\mathrm{TiO}_{2} \mathrm{vs}_{\mathrm{SiO}_{2}}$ wt\%, group 1 and 2 can be further subdivided. One can clearly see that both, group 1 and group 2, have both a high $\mathrm{TiO}_{2}$ 
and low $\mathrm{TiO}_{2}$ subgroup. Other samples of this study that are designated as transitional and low $\mathrm{SiO}_{2}$ plot closer to the Hunter Creek Basalt and to samples of CRBG.

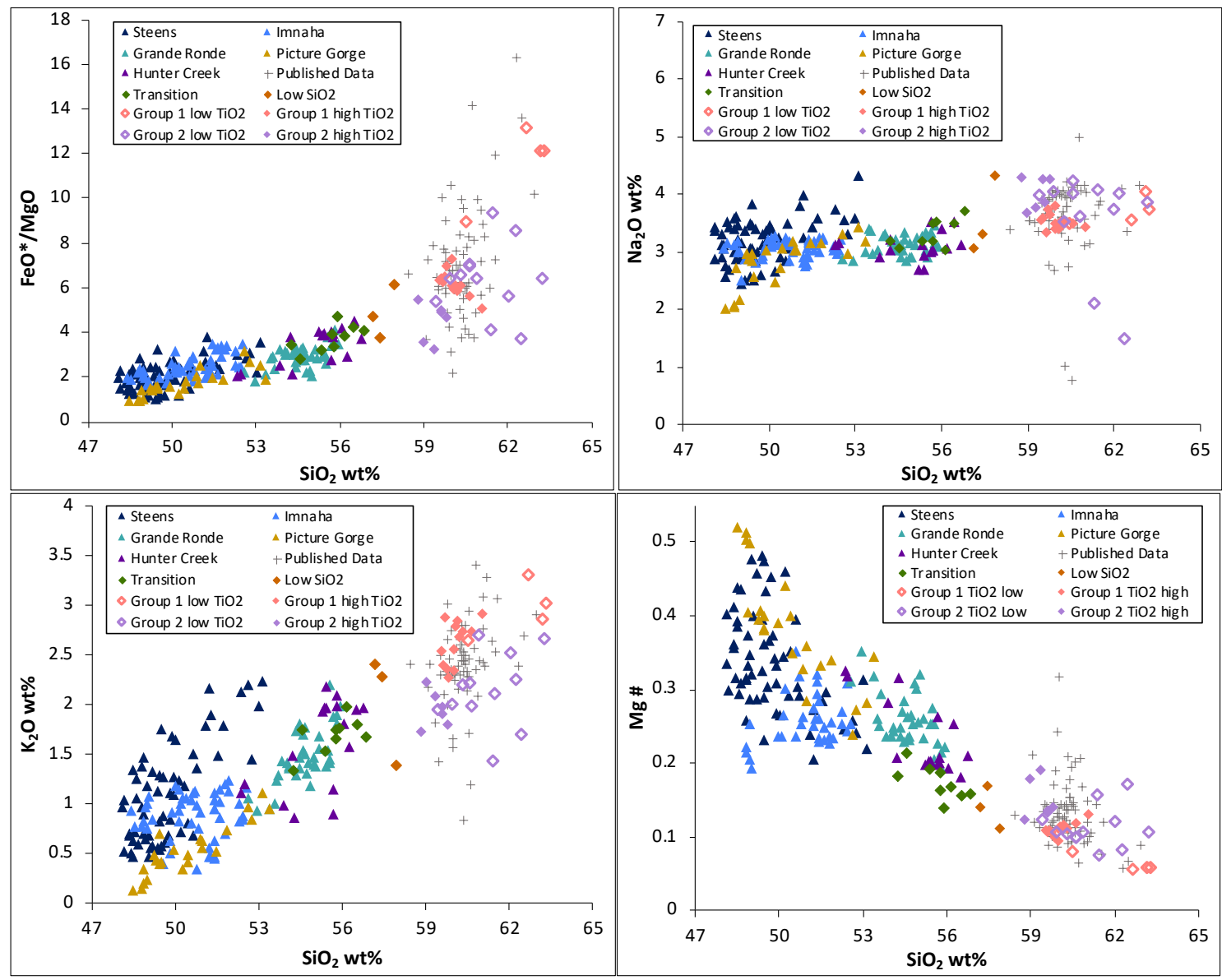

Figure 13. Major element $\mathrm{x}$-y plots for $\mathrm{Na}_{2} \mathrm{O}$ wt \%, $\mathrm{K}_{2} \mathrm{O}$ wt \%, $\mathrm{FeO}^{*} / \mathrm{MgO}$, and $\mathrm{Mg} \#$ vs. $\mathrm{SiO}_{2}$ wt\% for main phase CRBG members, Hunter Creek Basalt, Picture Gorge Basalt, and icelandites of this study. Data used for these plots can be found in Appendix A.

The icelandites from this study share many of the trace and rare earth element geochemical characteristics of the main phase CRB members at a slightly more enriched level (Figure 14-15). However, the averages of the icelandites from this study and the Hunter Creek Basalt differ from the main phase members of the CRBG in Sr and Ti, that indicate depletion relative to neighboring elements. Values for both of these elements, especially the concentration of Ti, fall closer to that of the Picture Gorge basalt. The Ba- 
Th-U trough for Hunter Creek Basalt, Picture Gorge Basalt and samples of this study are more pronounced than the remaining CRB main phase and published icelandite averages. In contrast the magnitude of the Nb-Ta trough for Grande Ronde, Hunter Creek, and the icelandites is much more pronounced than that of the Steens, Imnaha and Picture Gorge.

The C1 chondrite normalized (McDonough and Sun, 1995) REE diagram (Figure 15) illustrates the enrichment level differences of the icelandites and lavas of the Hunter Creek Basalt relative to other CRBG members. The trend of the icelandites follows that of the Imnaha, Grande Ronde, and Hunter Creek Basalt from La through Nd. From Sm to Gd the Grand Ronde Basalt, Hunter Creek Basalt, and icelandites break away from the enrichment pattern of the Imnaha Basalt. After Gd the Hunter Creek Basalt and the icelandites begin to diverge from the Grande Ronde Basalt and the REE enrichment pattern becomes much flatter, resembling that of the Picture Gorge Basalt. 


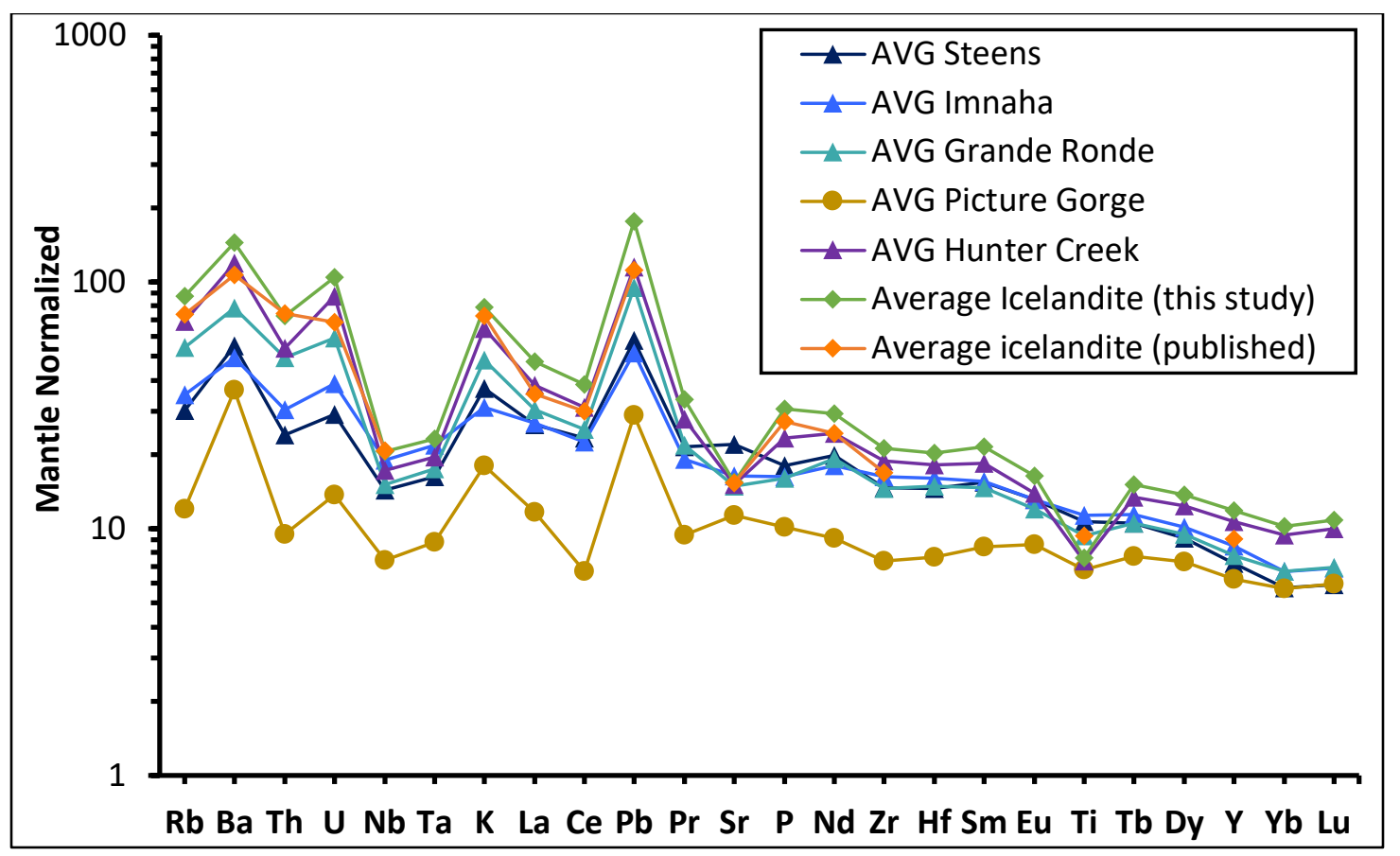

Figure 14. Primitive mantle normalized (Sun and McDonough, 1989) trace element diagram for averages of main phase CRBG members, Hunter Creek Basalt, published icelandites, and icelandites of this study. These values can be found in Appendix $A$.

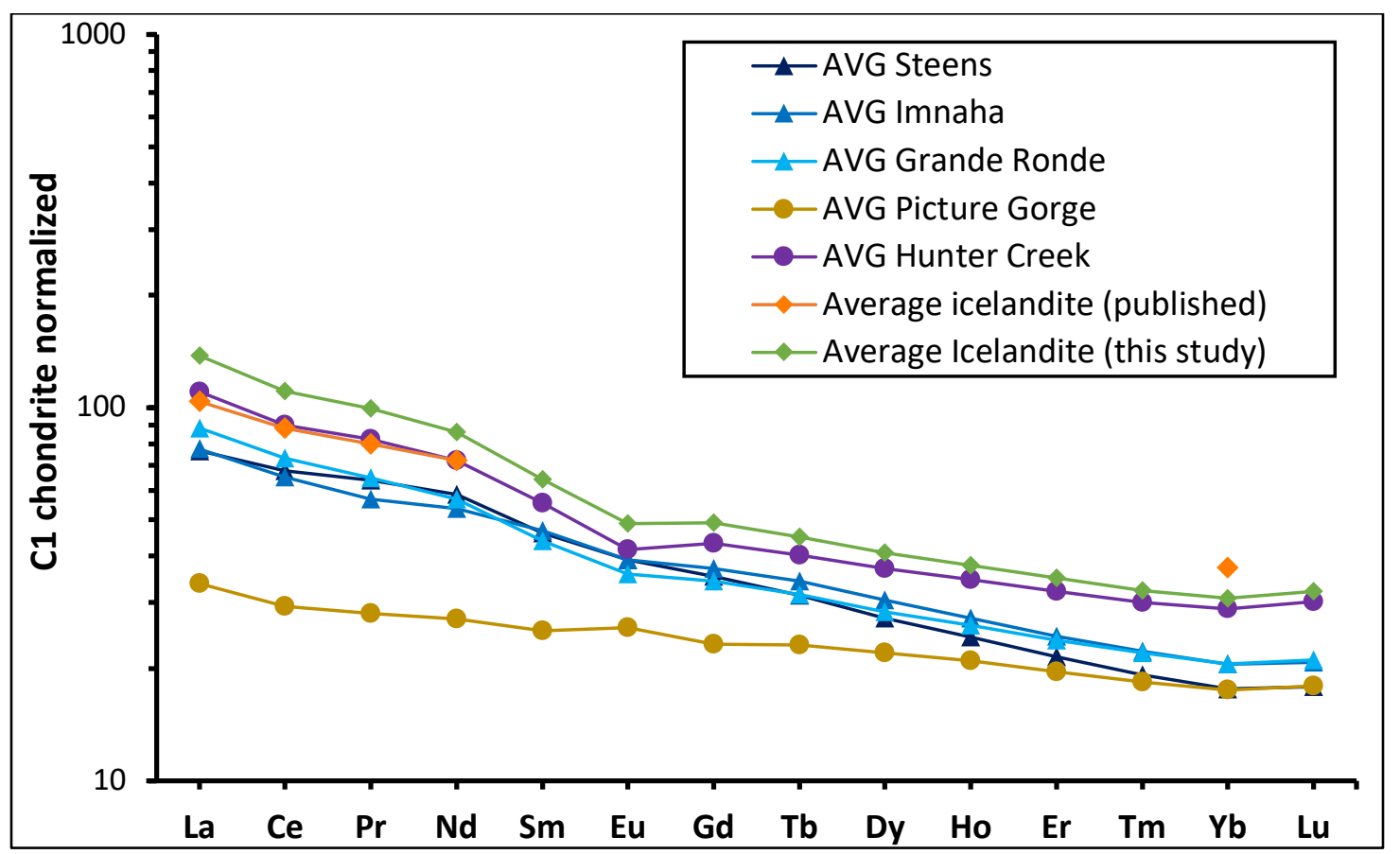

Figure 15. C1 chondrite (McDonough and Sun, 1995) normalized REE diagram for averages of main phase CRBG members, Hunter Creek Basalt, published icelandites, and icelandites of this study. These values can be found in Appendix A. 
There are slight variations in concentration for several trace and REE between the different icelandite groups (Figure 16). The spider diagram for the averaged icelandite groups shows some of the variations in trace element concentrations that distinguish group 1 (trace element enriched) and group 2 (trace element depleted). In rare earth element (REE) concentrations (Figure 17), the $\mathrm{TiO}_{2}$ subgroups have a similar pattern to the enrichment level until Dy, after which the low $\mathrm{TiO}_{2}$ subgroups become enriched in the least incompatible REE and the high $\mathrm{TiO}_{2}$ subgroups become depleted in the least incompatible REE. The Ba-Th-U trough is much steeper for the group 2 icelandites than it is for the group 1 samples. 

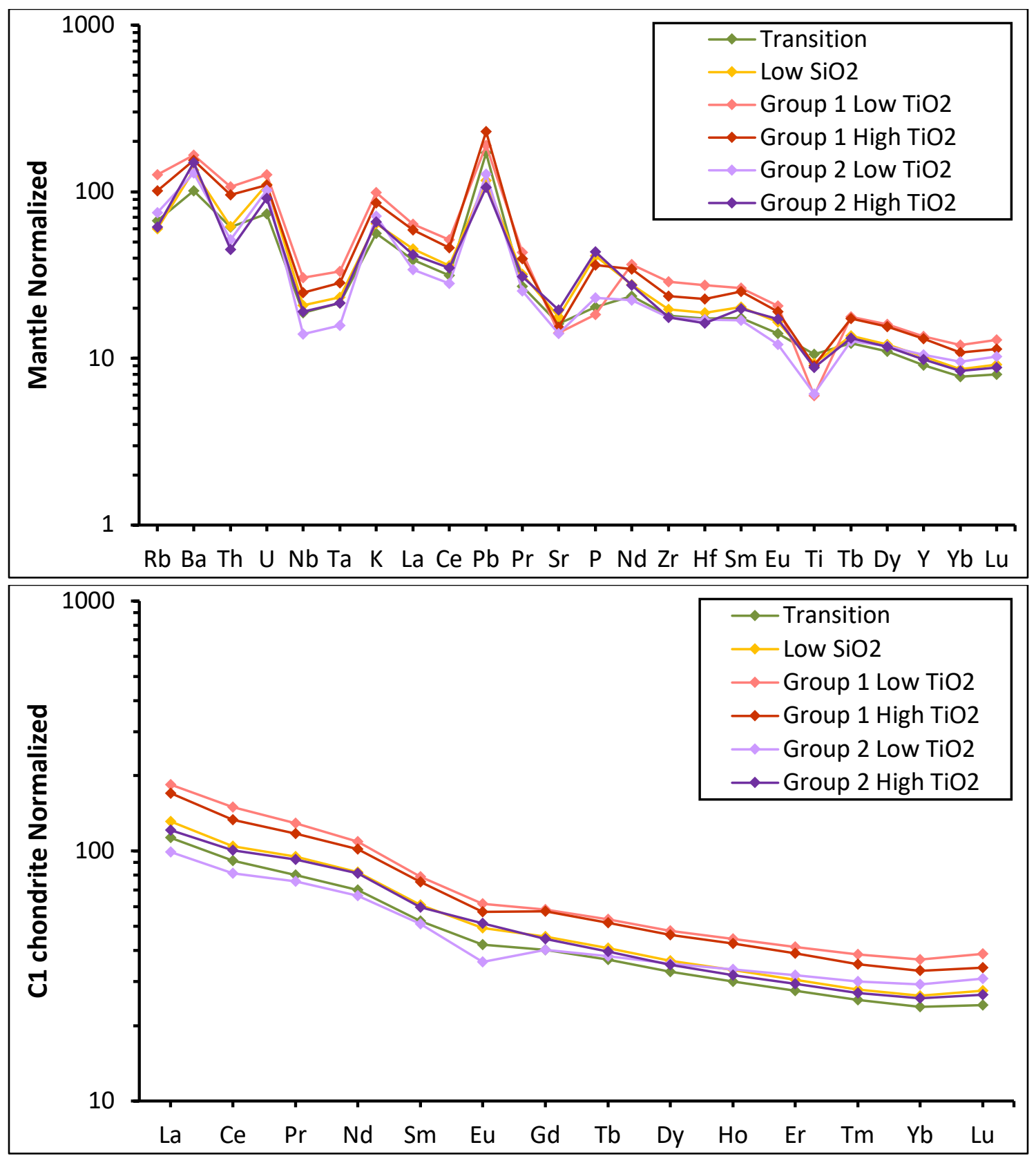

Figure 16. Primitive mantle normalized (Sun and McDonough, 1989) trace element diagram and C1 chondrite normalized (McDonough and Sun, 1995) REE diagram for average values of each icelandite group. These values can be found in Appendix A.

In all the key identifying trace and REE of the icelandites, the trend of higher enrichment in group 1 compared to that of group 2 can be observed. These key trace elements (including REE) are: $\mathrm{Nb}, \mathrm{Ta}, \mathrm{Th}, \mathrm{Zr}, \mathrm{Rb}, \mathrm{Y}, \mathrm{La}, \mathrm{Sm}, \mathrm{Pr}, \mathrm{Nd}, \mathrm{Gd}, \mathrm{Er}, \mathrm{Tm}, \mathrm{Yb}$, and $\mathrm{Lu}$. It can 
also be noted that the high $\mathrm{TiO}_{2}$ subgroup for the most part corresponds to a lower silica content. The icelandites can have very similar concentrations in certain trace elements while also having very different concentrations in other trace elements (Figure 14-17). Rubidium and barium are two good examples of the similar elemental trends between the two groups of icelandites (Figure 17). The plot of $\mathrm{Rb}$ versus $\mathrm{SiO}_{2}$ illustrates the clustering that occurs within the main icelandite groups and the $\mathrm{TiO}_{2}$ subgroups. The plots for $\mathrm{Rb}$ and $\mathrm{Ba}$ versus $\mathrm{SiO}_{2}$ also highlight the wide range in elemental concentration that can be found both in the Grande Ronde Basalt and Hunter Creek Basalt as well as the icelandites. Ba is one of the few trace elements that contains overlapping values between groups 1 and 2 .

There is a decrease in concentration with $\mathrm{Y}, \mathrm{Nb}$, Ta, (also for most REE elements, see Figures 17-23) as silica increases in group 2 icelandites while the group 1 icelandites having a positive trend of increasing enrichment with increasing silica content. Regarding Th, we have 2 strong linear trends starting with two separate clusters of the Hunter Creek basalt and going through data of the two groups of icelandites (Figure 19). The lower concentration group also tracks backward to the Th concentrations of the Picture Gorge basalts. The more enriched group 1 icelandites can be linearly traced back to the other main phase CRBG members. 

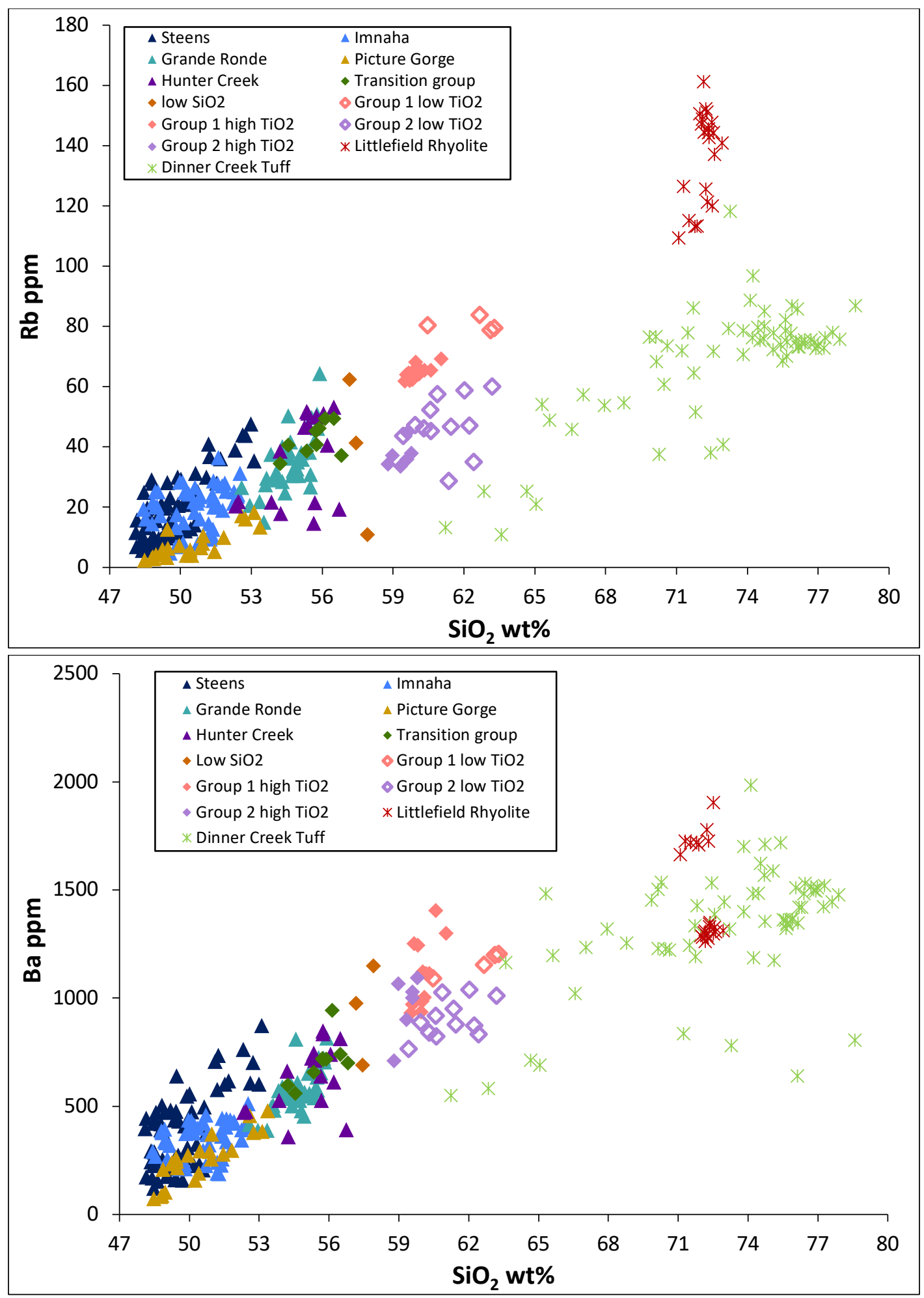

Figure 17. Major-trace element x-y plot $\mathrm{Rb}$ and $\mathrm{Ba}$ vs. $\mathrm{SiO}_{2}$ wt\% for main phase CRBG members, Hunter Creek Basalt, Picture Gorge Basalt, Dinner Creek Tuff, Littlefield Rhyolite and icelandites of this study. Data used for plots can be found in Appendix A. DIT samples from $60-65 \%$ SiO2 are Laser ablation ICP-MS for mafic globules in the Dinner Creek Tuff, 

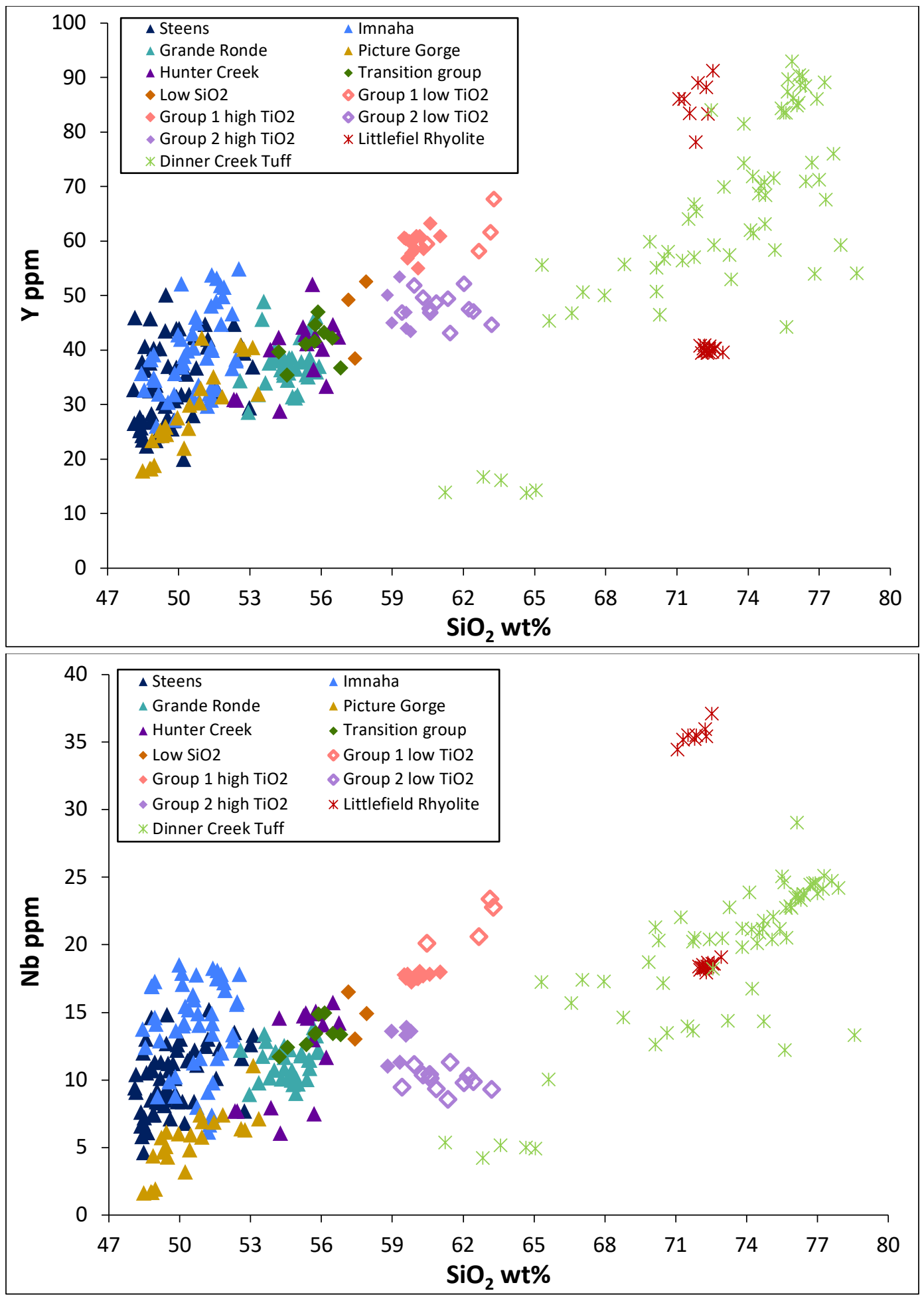

Figure 18. Major-trace element $\mathrm{x}-\mathrm{y}$ plot for $\mathrm{Y}$ and $\mathrm{Nb}$ vs. $\mathrm{SiO}_{2}$ wt\% for main phase CRBG members, Hunter Creek Basalt, Picture Gorge Basalt, Dinner Creek Tuff, Littlefield Rhyolite, and icelandites of this study. Data used for plots can be found in Appendix A. DIT samples from 60-65\% SiO2 are Laser ablation ICP-MS for mafic globules in the Dinner Creek Tuff, 

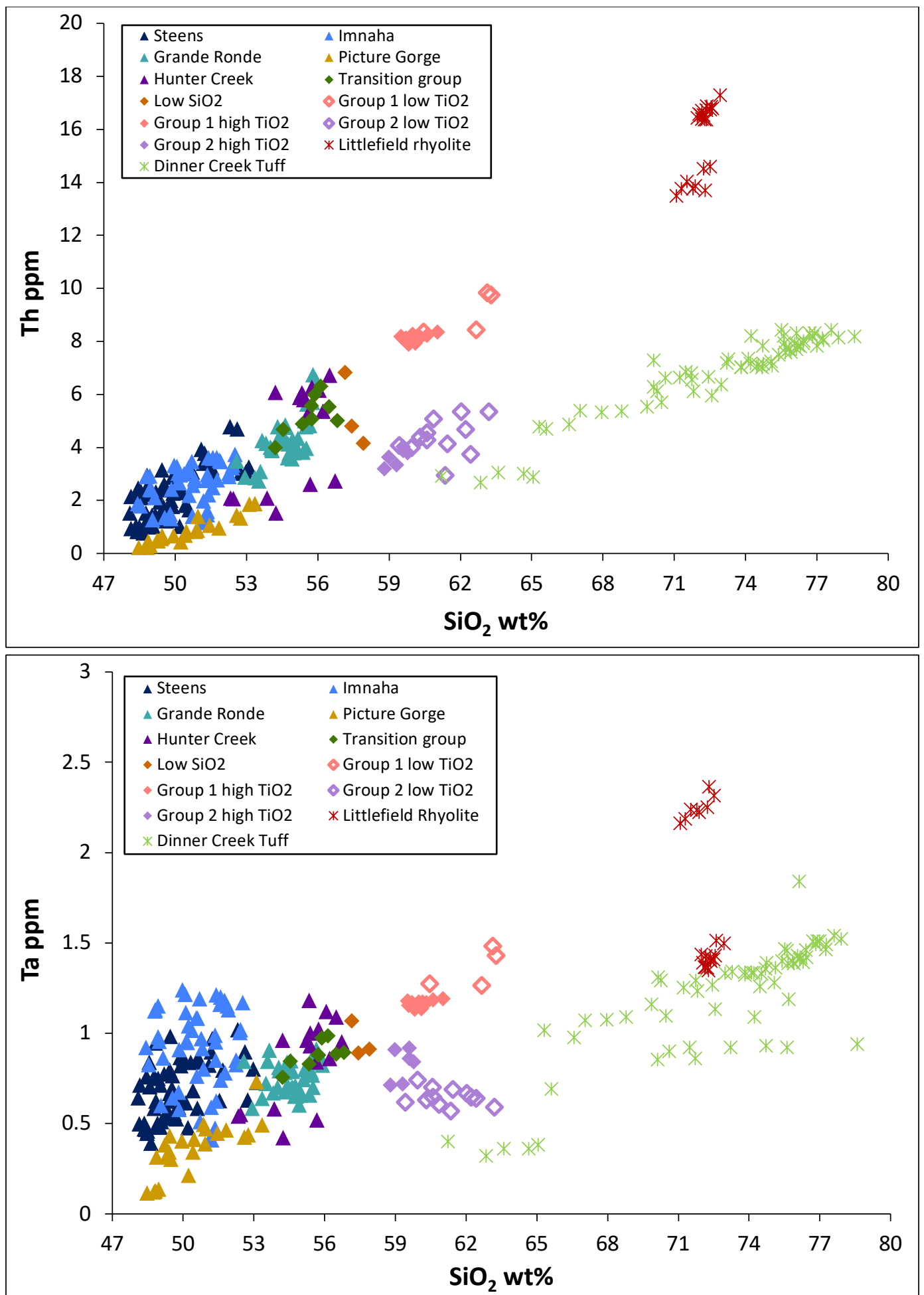

Figure 19. Major-trace element $x-y$ plots for Th and $\mathrm{Ta}_{\mathrm{vs}} \mathrm{SiO}_{2} \mathrm{wt} \%$ for main phase CRBG members, Hunter Creek Basalt, Picture Gorge Basalt, Dinner Creek Tuff, Littlefield Rhyolite and icelandites of this study. Data used for these plots can be found in Appendix A. DIT samples from 60-65\% SiO2 are Laser ablation ICP-MS for mafic globules in the Dinner Creek Tuff, 
The enrichment trend from the most incompatible to the least incompatible of the REE in the icelandites also displays the differences between the two main icelandite groups (Figures 20-23). The group 2 icelandites have enrichment that changes with the compatibility of the REE, while the enrichment of REE in the group 1 icelandites remains relatively unchanged. La, the first of the REE plotted has a negative trend of enrichment in group 2 and in Lu, final REE plotted the trend has changed to a positive trend of enrichment. The REE plots between these two elements show the change in the trend of enrichment from negative to positive for group 2 icelandites. 

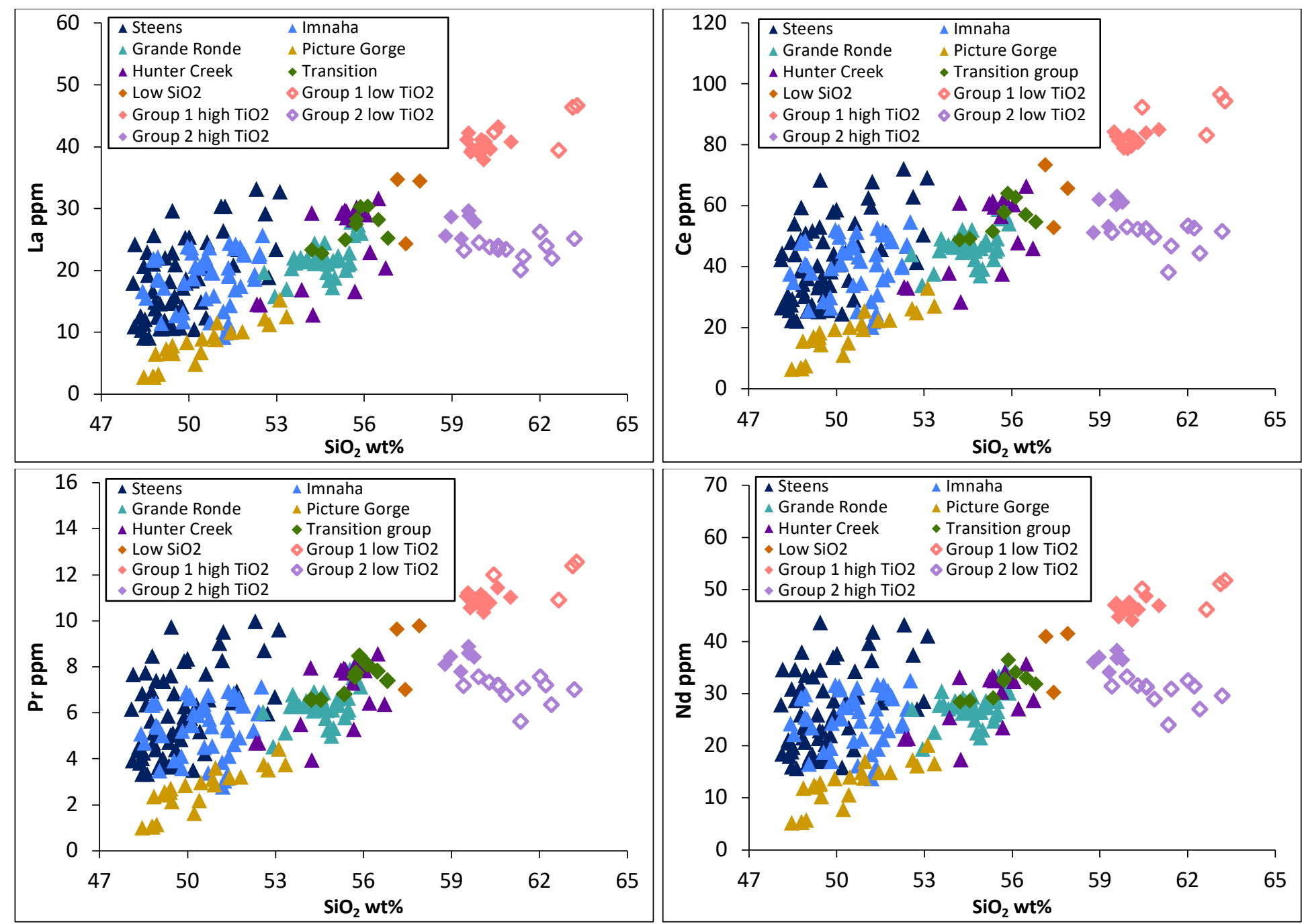

Figure 20. Plots of rare earth elements (REE) vs. $\mathrm{SiO}_{2} \mathrm{wt} \%$ for main phase CRBG members, Hunter Creek Basalt, Picture Gorge Basalt, and icelandites of this study. Data used for these plots can be found in Appendix A. 

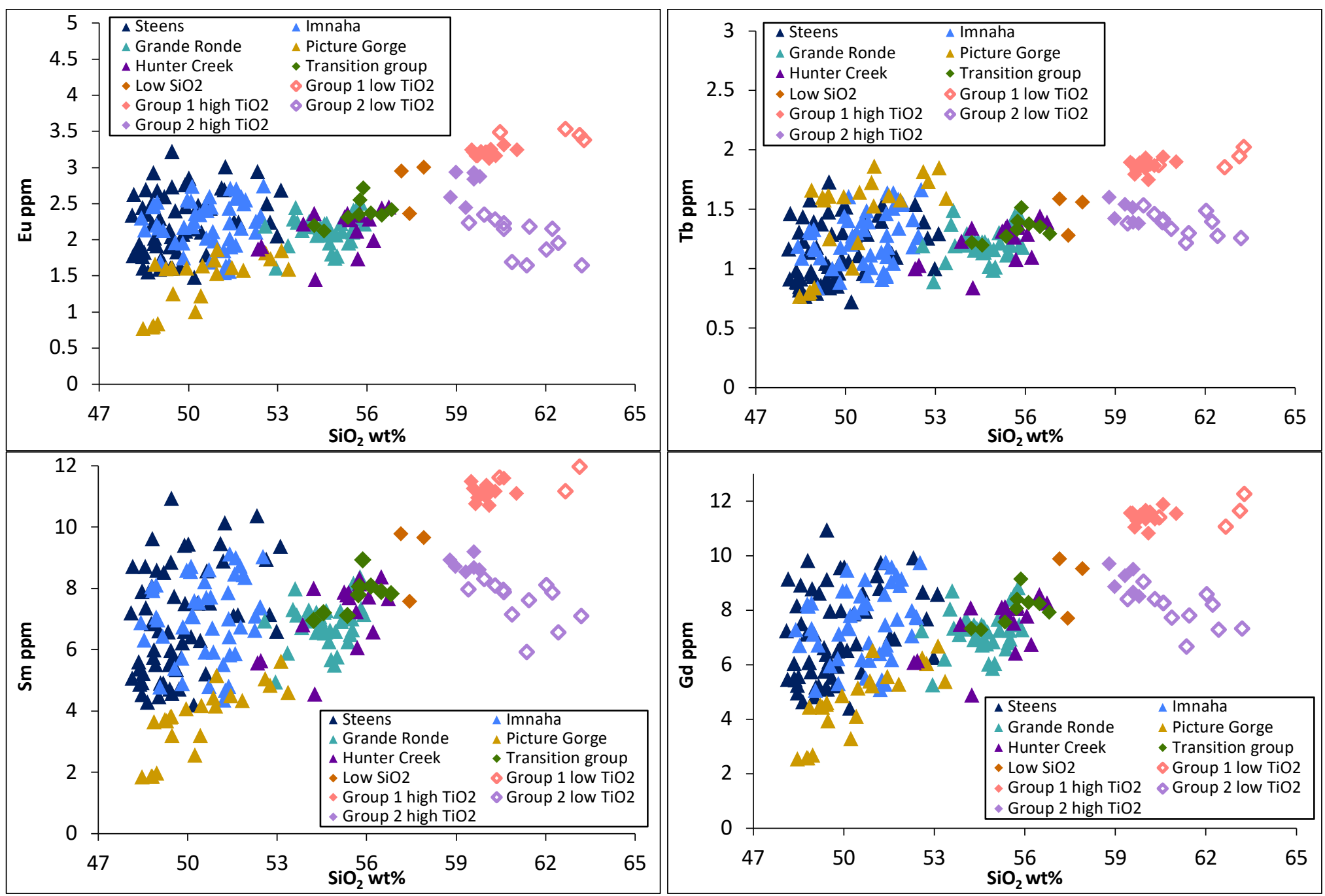

Figure 21. Plots of rare earth elements (REE) vs. $\mathrm{SiO}_{2} \mathrm{wt} \%$ for main phase CRBG members, Hunter Creek Basalt, Picture Gorge Basalt, and icelandites of

this study. Data used for these plots can be found in Appendix A. 

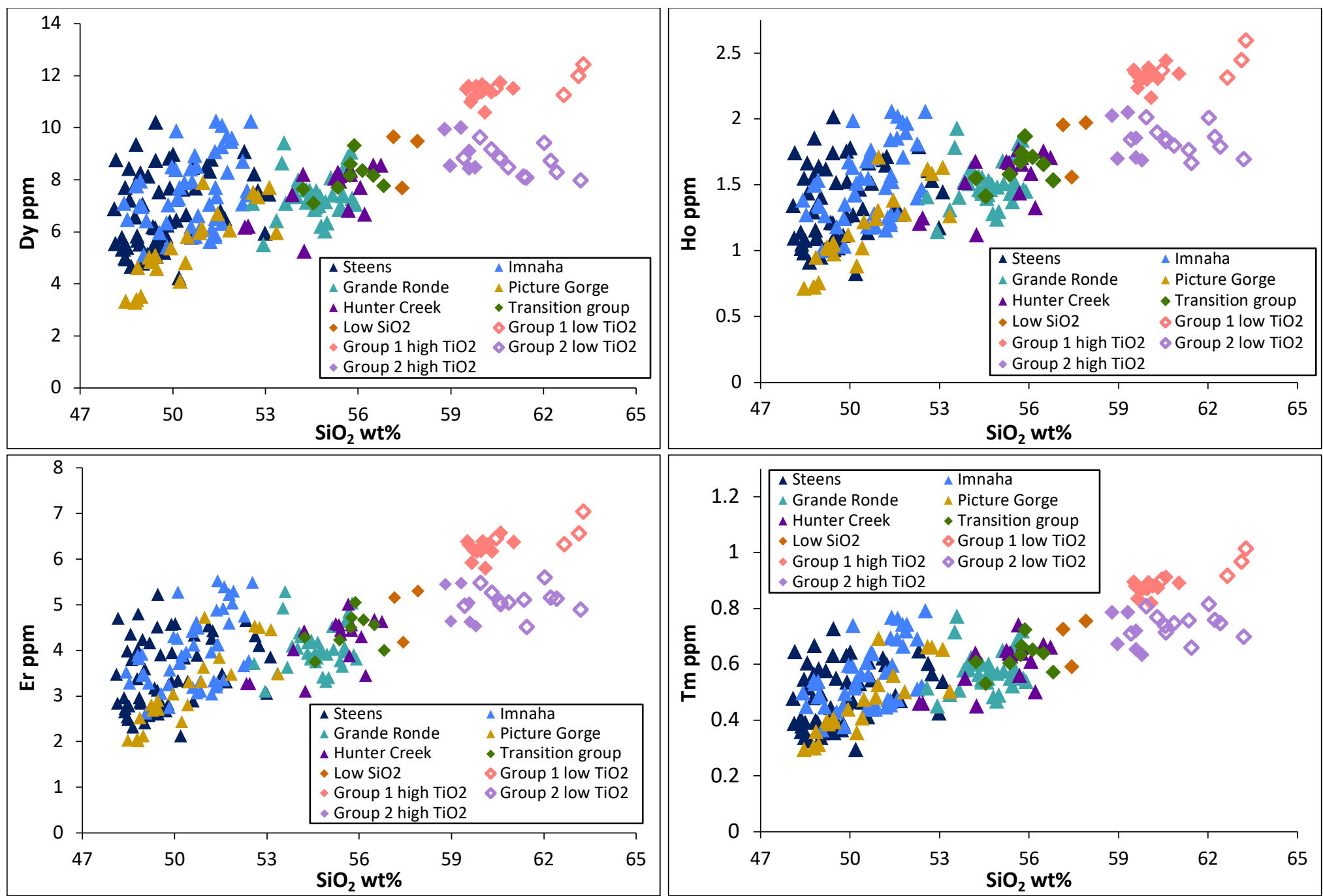

Figure 22. Plots of rare earth elements (REE) vs. $\mathrm{SiO}_{2}$ wt\% for main phase CRBG members, Hunter Creek Basalt, Picture Gorge Basalt, and icelandites of this study. Data used for these plots can be found in Appendix A. 

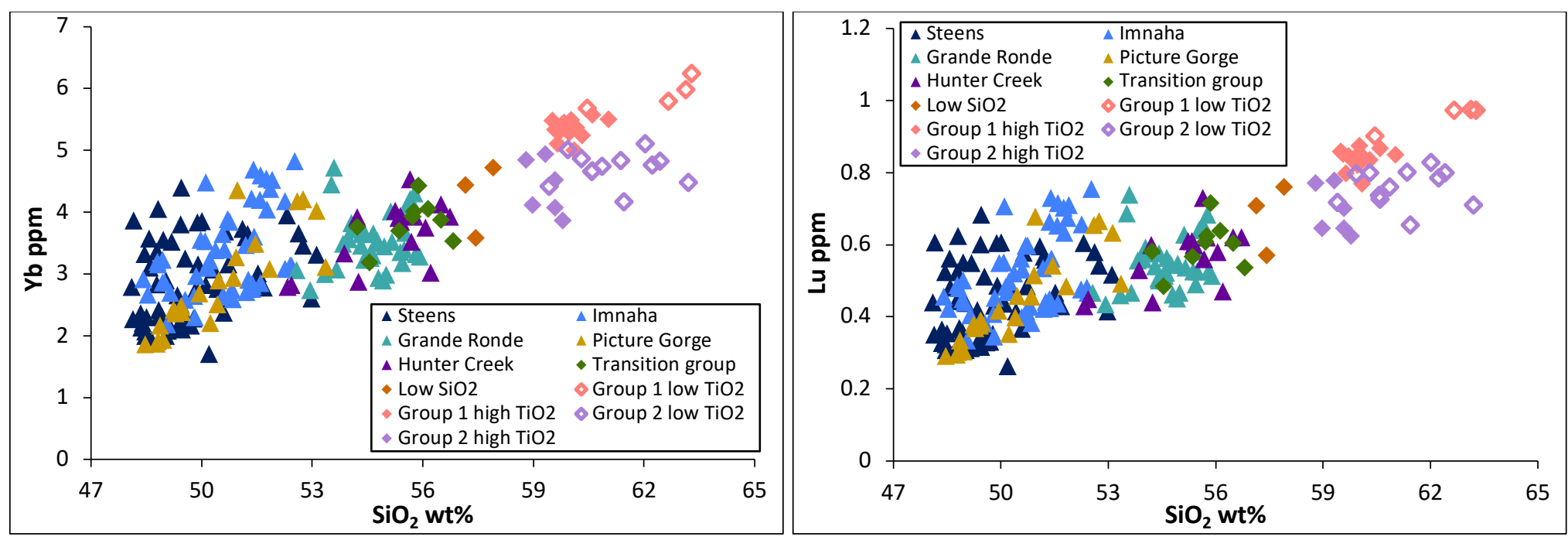

Figure 23. Plots of rare earth elements (REE) vs. $\mathrm{SiO}_{2}$ wt\% for main phase CRBG members, Hunter Creek Basalt, Picture Gorge Basalt, and icelandites of this study. Data used for these plots can be found in Appendix A. 


\section{COMPOSITION OF PHENOCRYSTIC MINERALS}

Ternary diagrams with SEM data of plagioclase feldspars and clinopyroxenes can be

found in figure 24 and 25 . The values that were chosen for plotting in the ternary diagrams for both the plagioclase feldspar and the clinopyroxene were the closest value to $100 \%$ for each phenocryst. Any values that were below $90 \%$ were discarded, the bulk of plagioclase feldspar compositions from SEM analysis fall into the andesine category, within a few exceptions that are categorized as labradorite. Overall, plagioclase compositions show a slight decrease in orthoclase concentration as the ratio of anorthite to albite increases.

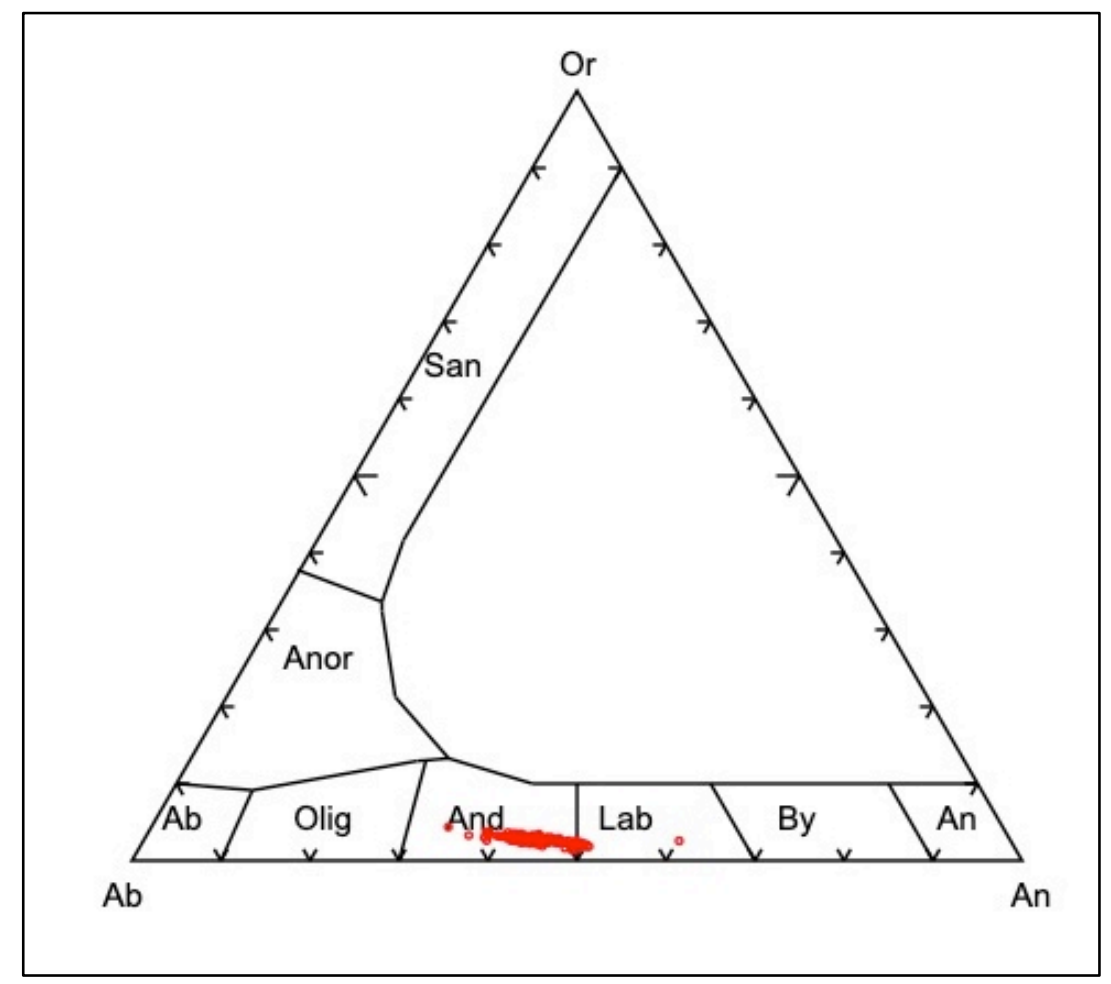

Figure 24. Ternary diagram of representative single point compositions for plagioclase feldspar phenocrysts determined by SEM-EDS analysis. Data used for plot can be found in Appendix C.

The SEM data acquired for clinopyroxene indicate a wide range when plotted on the enstatite (En)-ferrosillite (Fs)-wollastonite (Wo) ternary diagram (Fig. 25). The analyses 
of the clinopyroxene phenocrysts all fall within the augite and pigeonite range. The samples show some variation in the ratios of enstatite to ferrosillite, but for the majority of the samples they have roughly even concentrations of the two mineral endmembers.

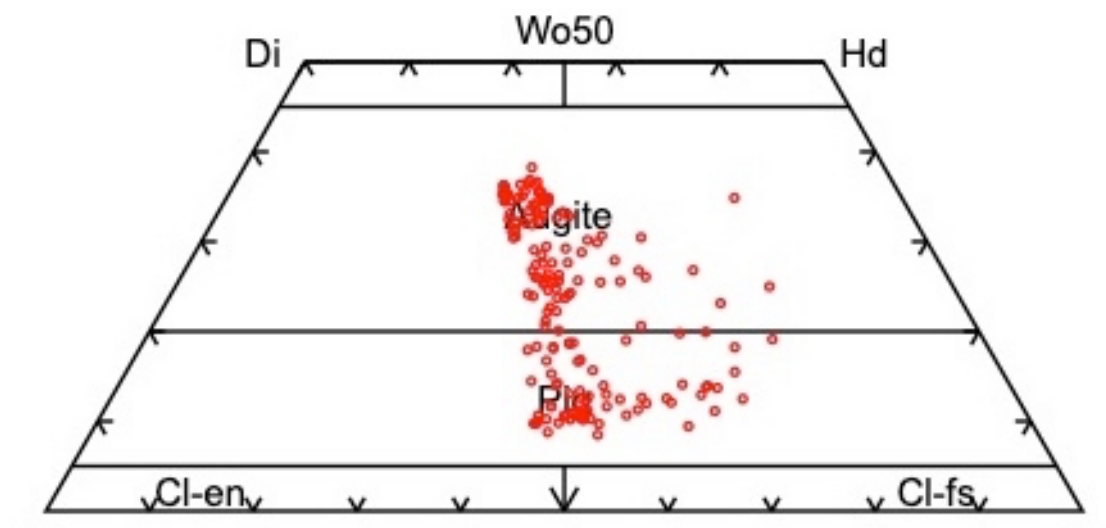

En

\section{Fs}

Figure 25. Ternary diagram of the representative single point compositions of clinopyroxene phenocrysts determined by SEM-EDS analysis. Data used for plot can be found in Appendix C.

Several of the phenocrysts selected for analysis turned out to be apatite (Figure 26).

Crystal sizes among these analyzed phenocrystic apatite ranged from 71 to $102 \mu \mathrm{m}$.

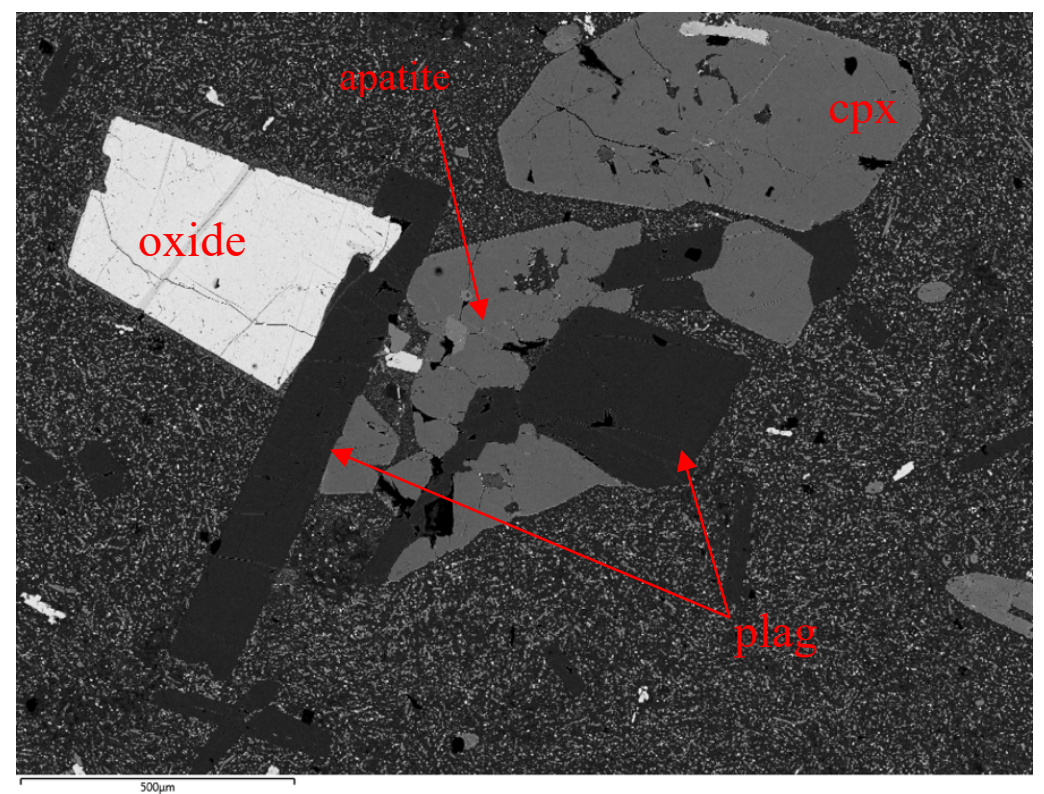

Figure 26. Electron image of site 4 containing apatite microphenocryst within phenocryst of clinopyroxene from sample MAC-17-16. 


\section{Discussion}

GEOCHEMICAL MODELING

I evaluated the generation of the two icelandite compositional groups with two

petrogenetic modeling approaches. The first one evaluated the evolution of the

icelandites via fractional crystallization from a basaltic/basaltic andesitic parent. The

second tested the scenario of a mixing origin of icelandite magma.

Table 3. Mineral proportions used for icelandite groups in fractional crystallization model.

\begin{tabular}{cccccc}
\hline \hline $\begin{array}{c}\text { Mineral } \\
\text { phase }\end{array}$ & $\begin{array}{c}\text { Plagioclase } \\
\text { (An70Ab30) }\end{array}$ & $\begin{array}{c}\text { Olivine } \\
\text { (Fo76Fa24) }\end{array}$ & $\begin{array}{c}\text { Clinopyroxene } \\
\text { (Di9Hed9) }\end{array}$ & $\begin{array}{c}\text { Ti-Fe oxide } \\
\text { (Mag50I150) }\end{array}$ & Bulk Mineral \\
\hline Group 1 & 0.49 & 0.1 & 0.23 & 0.18 & 1.00 \\
Group 2 & 0.61 & 0.12 & 0.14 & 0.13 & 1.00 \\
\hline \hline
\end{tabular}

Table 4. Estimated mineral chemistry for major rock forming minerals of mid-Miocene icelandites and calculated bulk mineral used for crystalization models of group 1 and 2 icelandites.

\begin{tabular}{|c|c|c|c|c|c|c|}
\hline $\begin{array}{l}\text { Mineral } \\
\text { phase }\end{array}$ & $\begin{array}{l}\text { Plagioclase } \\
\text { (An70Ab30) }\end{array}$ & $\begin{array}{c}\text { Olivine } \\
\text { (Fo76Fa24) }\end{array}$ & $\begin{array}{c}\text { Clinopyroxene } \\
\text { (Di9Hed9) }\end{array}$ & $\begin{array}{c}\text { Ti-Fe oxide } \\
\text { (Mag50II50) }\end{array}$ & $\begin{array}{c}\text { Bulk } \\
\text { Mineral } \\
\text { Group } 1\end{array}$ & $\begin{array}{c}\text { Bulk } \\
\text { Mineral } \\
\text { Group } 2\end{array}$ \\
\hline SiO2 & 50.83 & 39.03 & 52.15 & 0.19 & 40.84 & 43.01 \\
\hline TiO2 & & 0.05 & 0.14 & 24.45 & 4.44 & 3.20 \\
\hline Al2O3 & 31.39 & & 1.79 & 0.38 & 15.86 & 19.44 \\
\hline FeO* & 0.07 & 18.22 & 5.81 & 70.59 & 15.90 & 12.22 \\
\hline $\mathrm{MnO}$ & & 0.23 & 0.05 & 0.18 & 0.07 & 0.06 \\
\hline MgO & 0.01 & 42.91 & 14.43 & 0.28 & 7.66 & 7.21 \\
\hline $\mathrm{CaO}$ & 13.75 & 0.02 & 24.15 & 0.33 & 12.35 & 11.81 \\
\hline $\mathrm{Na2O}$ & 3.37 & & 0.38 & & 1.74 & 2.11 \\
\hline K2O & 0.08 & & & & 0.04 & 0.05 \\
\hline P2O5 & & & & & 0.00 & 0.00 \\
\hline Total & 99.50 & 100.45 & 98.89 & 96.39 & 98.89 & 99.12 \\
\hline
\end{tabular}

The bulk mineral composition and modes used for the geochemical models were based

on the composition and mineral abundances in andesites and tholeiitic basalts of the

CRBG (e.g. the ferro-andesites of the Grande Ronde Basalt studied by Lambert et al., 1995) and known mineral assemblages of other icelandites including Thingmuli

(Carmichael, 1964), North Shore Volcanic Group (Green and Fitz, 1993 and Vervoort and 
Green, 1997), and Heidarspordur Ridge (Mancini et al., 2015 and Jónasson, 2005).

Phenocrystic phases that were found to be common to all the known icelandite mineral assemblages were plagioclase feldspar, clinopyroxene, iron rich olivine, and Fe-Ti oxides. In addition, the ferro-andesites of Lambert et al. (1995) also contained apatite, and chlorophaeite, an alteration product of olivine. Apatite as accessory minerals was not included in the geochemical models as it is likely to have begun crystallizing very late in the solidification process at crystallization amounts of $>60 \%$ which is at the upper end of the modeling range.

I chose potential parents from the CRBG that are compositionally closest to the icelandites, and these are Grande Ronde Basalt samples (including those from the Hunter Creek Basalt, Figure 10-15). Furthermore, the selection of which two Grande Ronde/Hunter Creek Basalt samples are taken as potential parent magmas for Group 1 and Group 2 icelandites, respectively, is based on which samples are deemed suitable based on trendlines for incompatibly behaving trace elements (e.g., Th vs SiO2, Figure 19). From the clusters of suitable samples, averages for a slightly enriched Group 1 parent and a slightly depleted Group 2 parent were calculated (see Appendix). Detailed results of the Rayleigh fractional crystallization model can be found in appendix D. The Rayleigh model results show that the two groups of icelandites are unlikely to have formed by fractional crystallization alone. The formation of the group 1 icelandites by fractional crystallization is not possible (Figure 29,31 ) in terms of major elemental constraints but is possible in context of incompatible trace elements including REE. The 
group 2 icelandites yielded similar results in with the formation of group 2 (Figure 30, 32) being possible via fractional crystallization for incompatible trace elements but is less feasible for major elements. 

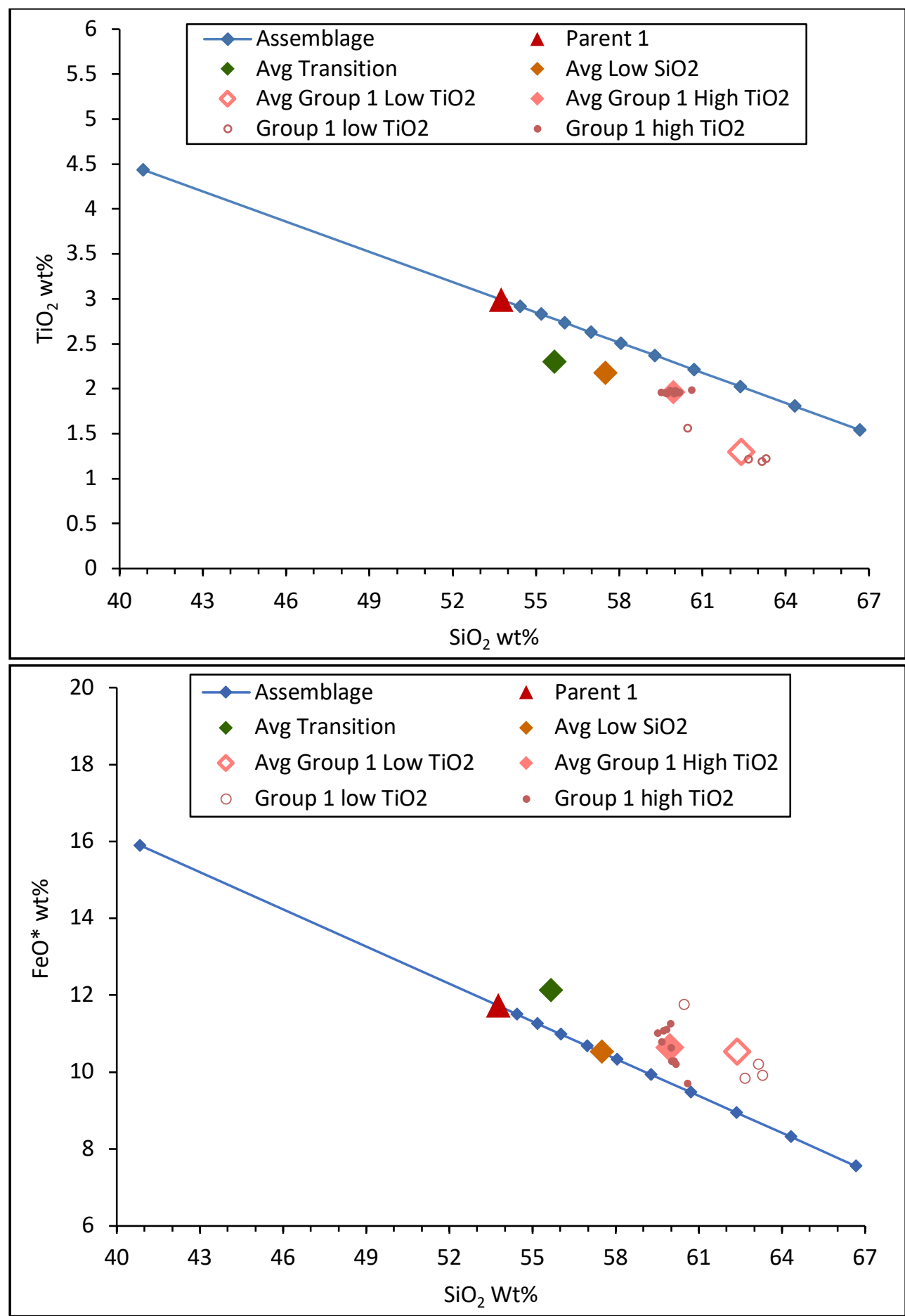

Figure 27. Variation diagrams of Group 1 icelandites and mass balance modeling results for the two important major elements, Fe and $\mathrm{Ti}$. The blue line is the calculated crystallization path using the calculated assemblage beginning at $42 \% \mathrm{SiO}_{2}$ (blue diamond) from the mafic parent magma (red triangle), each tick mark (blue diamonds) along the crystallization line represents crystallization increments of $5 \%$. Labeled points include the samples of group 1 as well as averages of the transition, low $\mathrm{SiO}_{2}$, and group 1 icelandites. Detailed results of the mass balance model can be found in appendix D. 

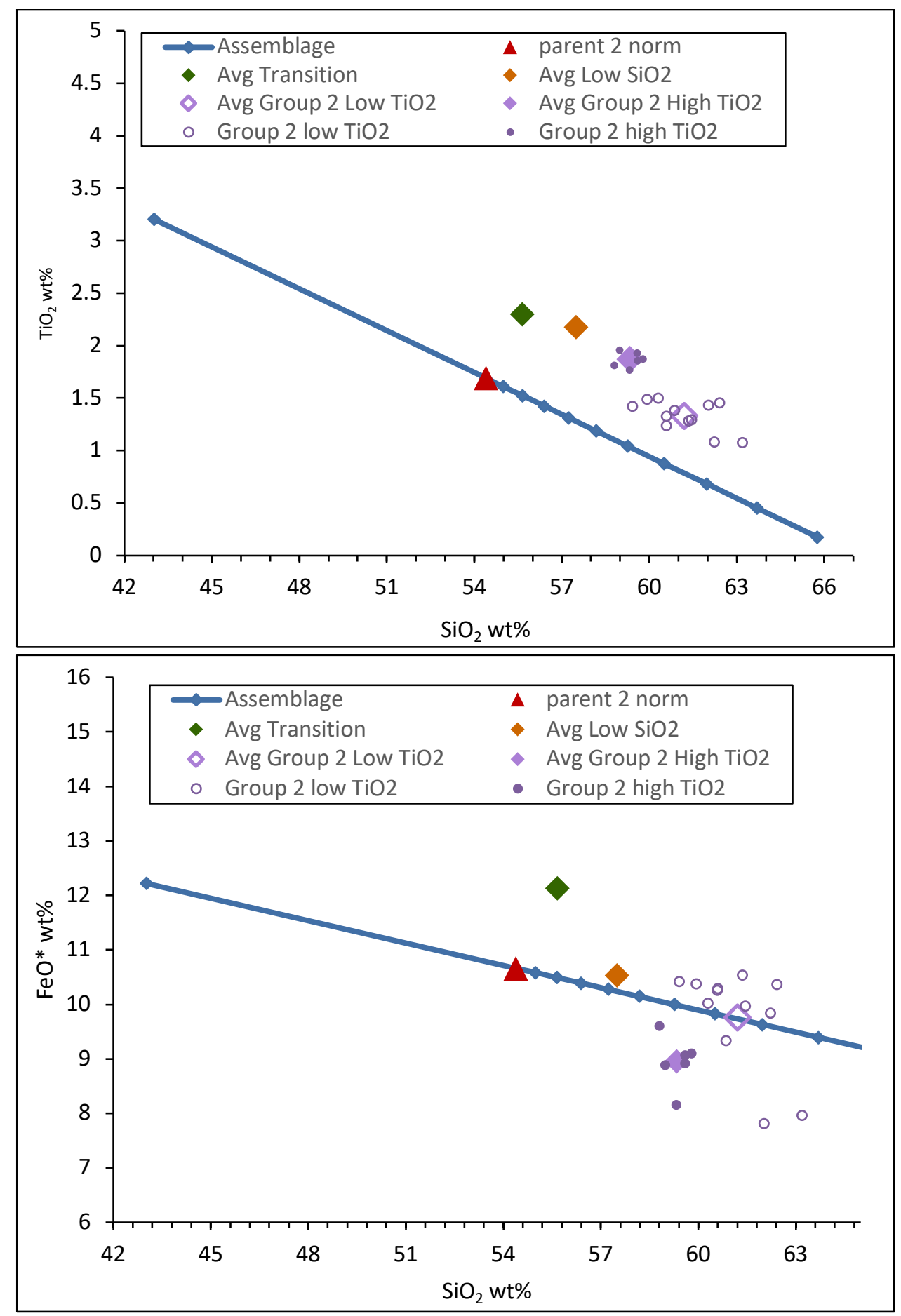

Figure 28. Variation diagrams of Group 2 icelandites and mass balance modeling results for the two important major elements, Fe and Ti. The blue line is the calculated crystallization path using the calculated assemblage beginning at $43 \% \mathrm{SiO}_{2}$ (blue diamond) from the mafic parent magma (red triangle), each tick mark (blue diamonds) along the crystallization line represents crystallization increments of $5 \%$. Labeled points include the samples of group 1 as well as averages of the transition, low $\mathrm{SiO}_{2}$, and Group 2 icelandites. Detailed results of the mass balance model can be found in appendix $D$. 
Results of the fractional crystallization models were plotted for two of the most important major element oxides, $\mathrm{TiO}_{2}$ and $\mathrm{FeO}$ (Figure 27 and 28). The blue line in both diagrams displays the projected crystallization path from the estimated parent magmas. The trajectory of the blue line is defined by the composition of the parent magmas and the composition of the "bulk" mineral crystallizing as estimated from modal proportions. The calculated composition trend from the parent magma towards the icelandites does not reproduce the observed compositions (figure 27). The group 1 icelandites could have formed by fractional crystallization processes if the concentration of $\mathrm{FeO}$ were higher and the concentration of $\mathrm{TiO}_{2}$ were lower in the parent. For group 2, somewhat the opposite compositional systematics to group 1 would be required to be consistent with fractional crystallization. This means, the concentration of $\mathrm{TiO}_{2}$ of parent to generate group 2 would need to be higher. Observed $\mathrm{FeO}^{*}$ concentrations create a more difficult scenario and could only be reconciled if bulk mineral and parent would both be higher in $\mathrm{FeO}^{*}$ leading to a steeper trend line than shown on (Fig. 28). 

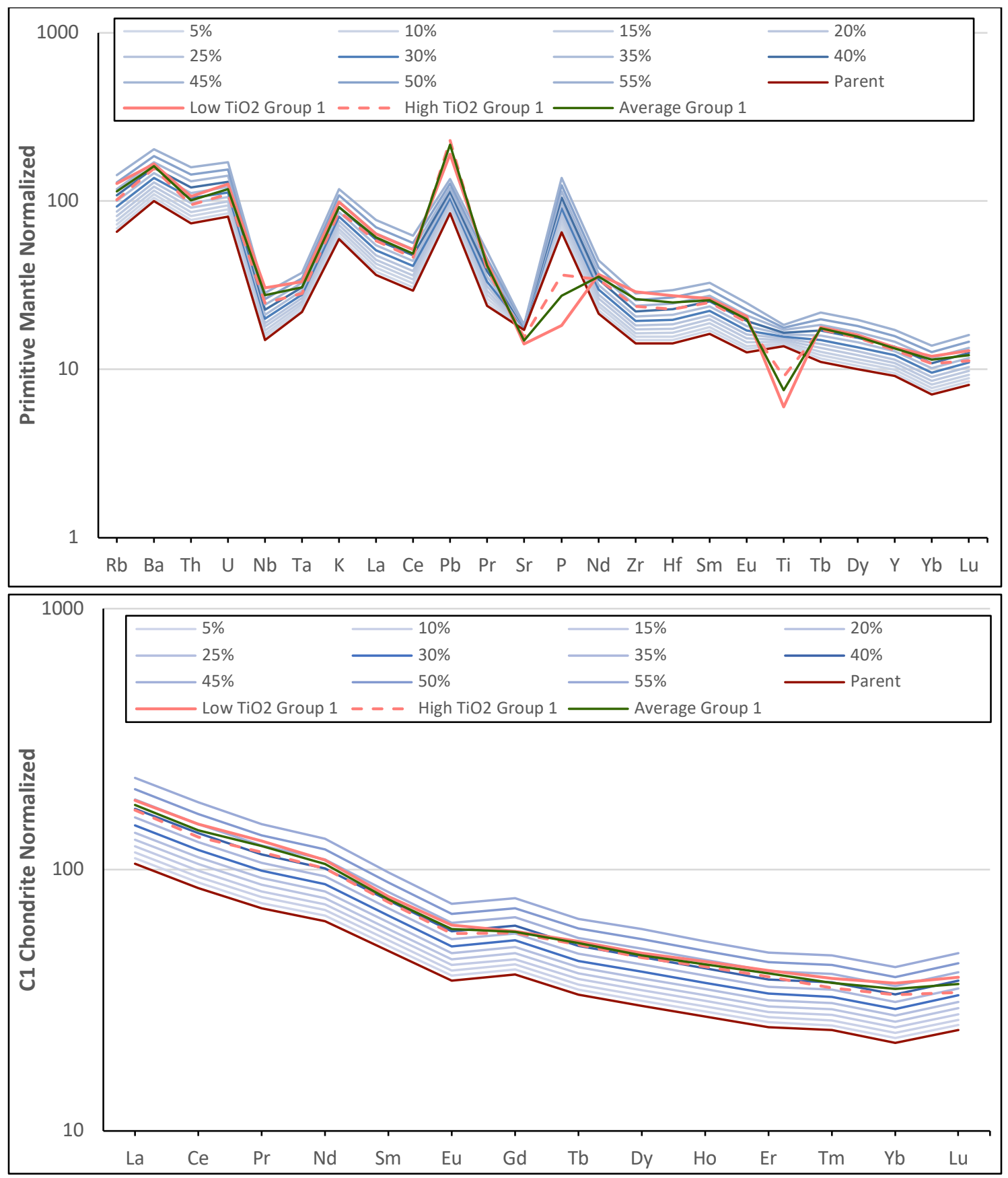

Figure 29. Spider diagram and REE diagram with fractional crystallization models, estimated parent, and observed Group 1 compositions. 


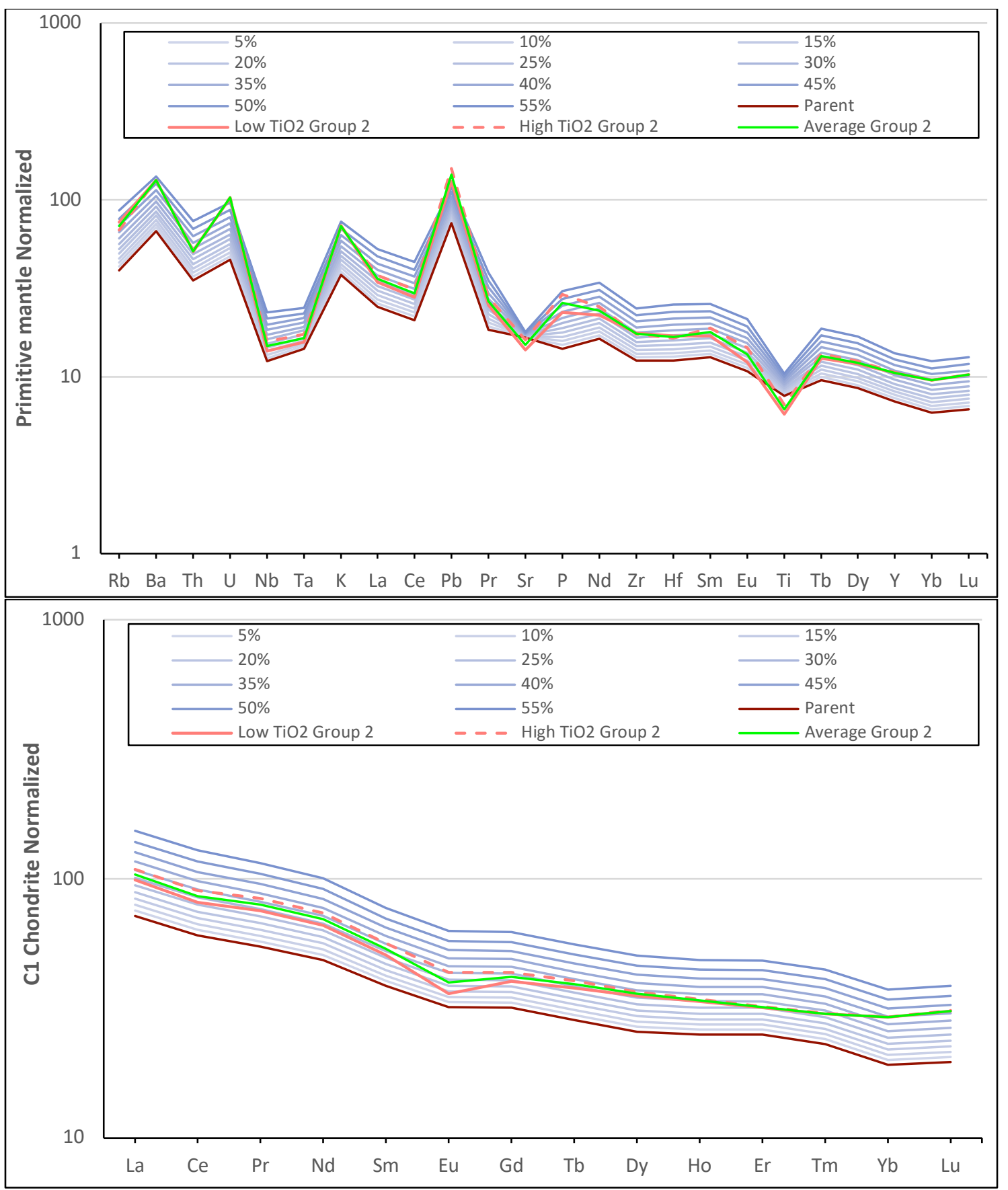

Figure 30. Spider diagram and REE diagram with fractional crystallization models, estimated parent, and observed Group 2 compositions.

The Rayleigh fractional crystallization model for group 1 and 2 in trace elements and REE produced a different outcome that that of the major element oxides (see Figures 29 and 30). One can see that unlike the major element model, it is possible to generate a 
magma that is similar to group 1 and 2 icelandites with Rayleigh crystallization models. Within both groups, strontium and titanium are the elements that do not result in concentrations similar to those of the icelandites using this type of model. Additionally, one cannot reach the high concentration level observed in phosphorus in group 1 using just Rayleigh fractionation.

MAGMA MiXING

The mass balance and Rayleigh fractionation models were not able to produce the distinct geochemical signature that we see in the icelandites of groups 1 and 2 . The trace and the REE did show however that some degree of fractionation is likely involved in the generation of the icelandites, but it is not the sole process involved. The next most likely process that could have been operating to generate these magmas is mixing between a mafic endmember and a felsic endmember, I used as mafic endmembers the same two composition that I used as parent magmas for the fractional crystallization models. As silicic end members I used an average composition of the upper Littlefield rhyolite and averages of the 4 units of the Dinner Creek Tuff. The selection is again based on suitable incompatible trace element systematics observed in scatter diagrams (Figures 17-23). The differing composition of the mafic endmember are meant to account for the differing concentrations of the two icelandite groups. The mixing of $\sim 63 \%$ of a slightly more enriched mafic endmember with $37 \%$ of the Upper Littlefield Rhyolite as the rhyolitic endmember successfully produces the geochemical signature of the Group 1 icelandite (Figure 31). The fit of the mixing model between a slightly more enriched mafic endmember with the Upper 
Littlefield Rhyolite only has misfits with P and Ti in trace elements and a slight misfit in

\section{Eu for REE (Figure 31).}
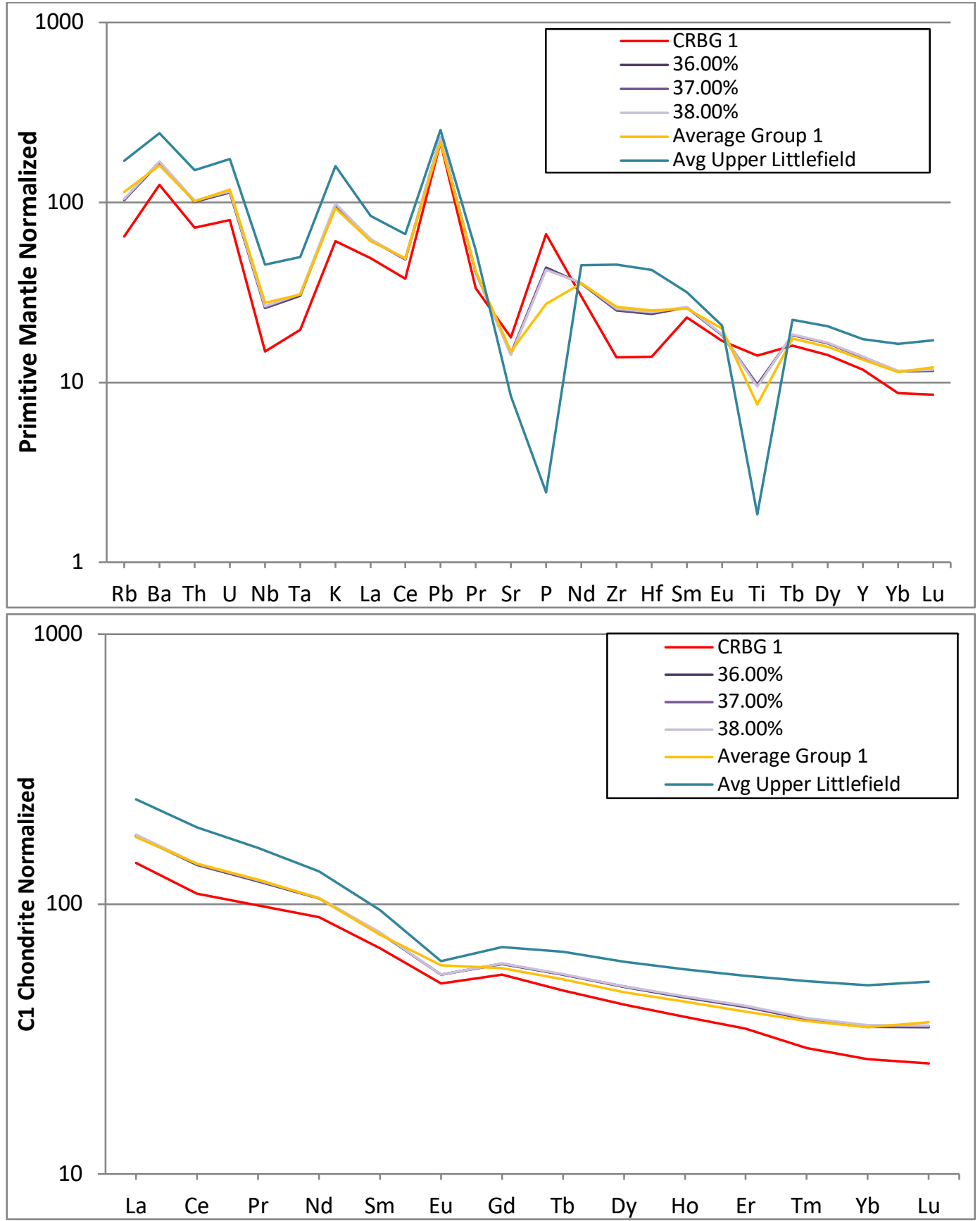

Figure 31. Primitive mantle normalized (Sun and McDonough, 1989) trace element diagram and C1 chondrite normalized REE (McDonough and Sun, 1995) diagram for results of mixing of averaged group 1 CRBG mafic endmember (determined by linear regression of group 1 icelandite concentrations) with Upper Littlefield Rhyolite. These values and the calculations for the mixing model can be found in Appendix E. 


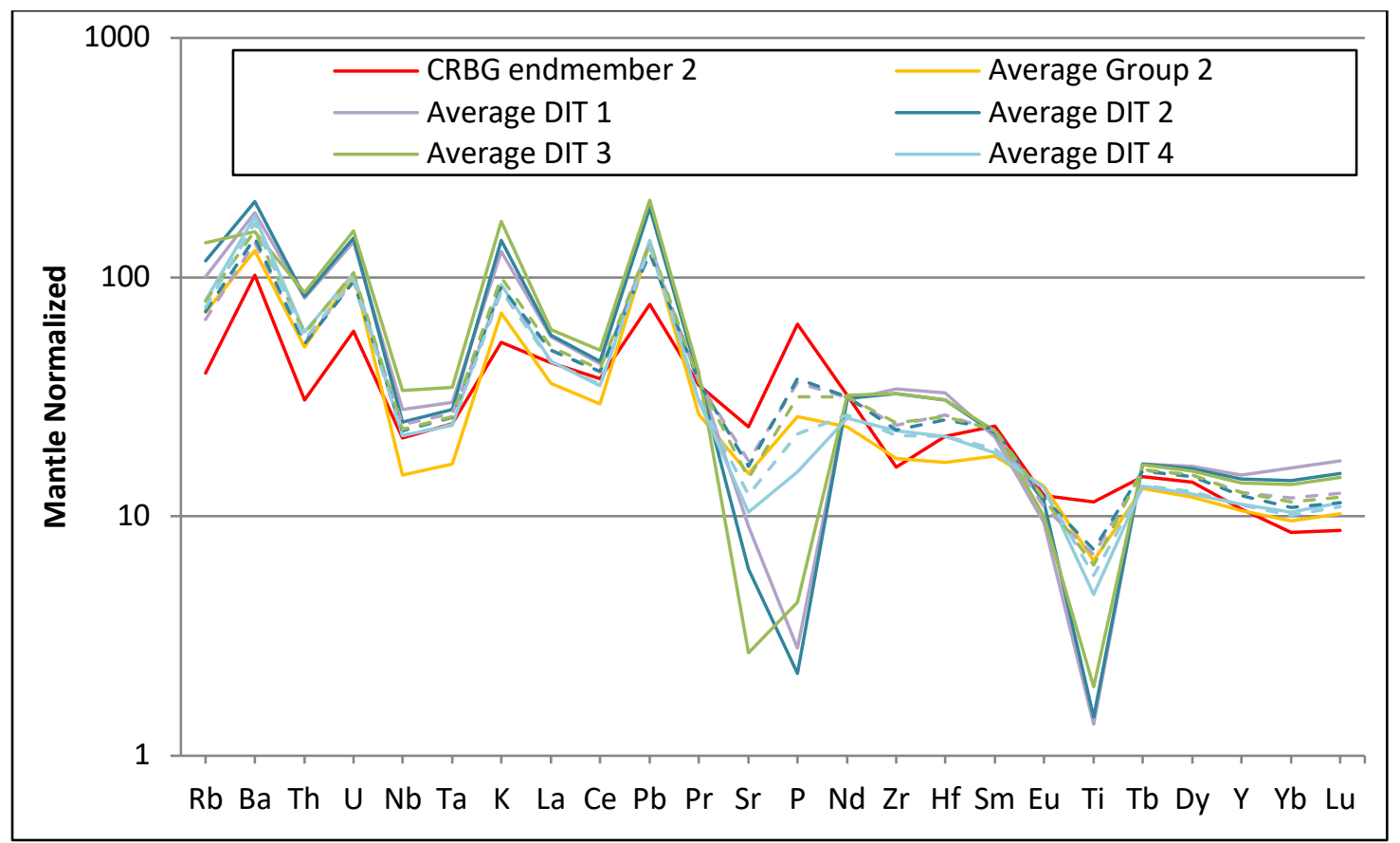

Figure 32. Primitive mantle normalized (Sun and McDonough, 1989) trace element diagram and C1 chondrite (McDonough and Sun, 1995) normalized REE diagram for mixing results of CRBG mafic endmember (determined by linear regression of group 2 icelandite concentrations) with DIT units 1 through 4 to generate group 2 compositions. (see Appendix E for compositions of mixing model)

The trace element mixing model of a group 2 CRBG-like endmember was generated with Dinner Creek Tuff (DIT) units 1-4 as the rhyolitic endmember (Figure 32). DIT units 1 and 2 were very quickly determined to not be the best candidate for producing the group 2 icelandites through mixing (see Appendix E). It is evident that a more depleted GRB like mafic endmember would be needed in order to produce the geochemical signature that we see with group 2 . 


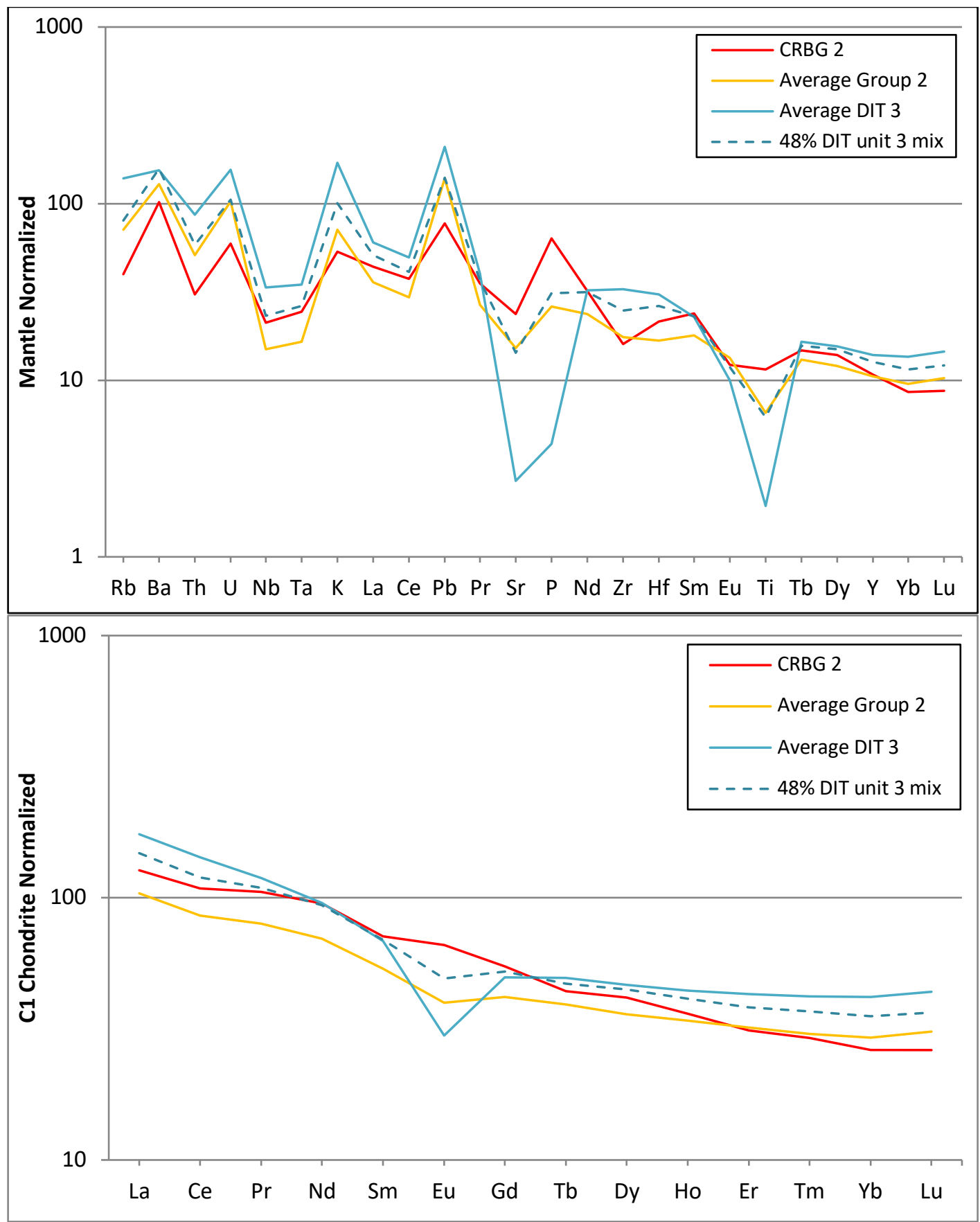

Figure 33. Primitive mantle normalized (Sun and McDonough, 1989) trace element diagram and C1 chondrite (McDonough and Sun, 1995) normalized REE diagram for mixing results of CRBG mafic endmember (determined by linear regression of group 2 icelandite concentrations) with DIT unit 3 to generate group 2 compositions. (see Appendix E for compositions of mixing model)

The mixing percent for the two DIT units that came the closest to the geochemistry of the icelandites are $52 \%$ of a depleted Grande Ronde mafic endmember and $\sim 48 \%$ 
Dinner Creek Unit 3 (Figure 33 and 34). 77\% DIT unit 4 would need to mix with the depleted Grande Ronde type mafic endmember to produce the group 2 icelandites. DIT Unit 3 gets closer to the geochemical of the icelandites than DIT units 1 or 2 but still has a number of misfits in trace and REE (Figure 33) as well as having an overall too high level of enrichment.-Dinner Creek Unit 4 has the most ideal match to the trace and REE geochemical signature of the icelandites when $\sim 77 \%$ percent DIT unit 4 is mixed with $23 \%$ of the GRB endmember for group 2 (Figure 34 ). 


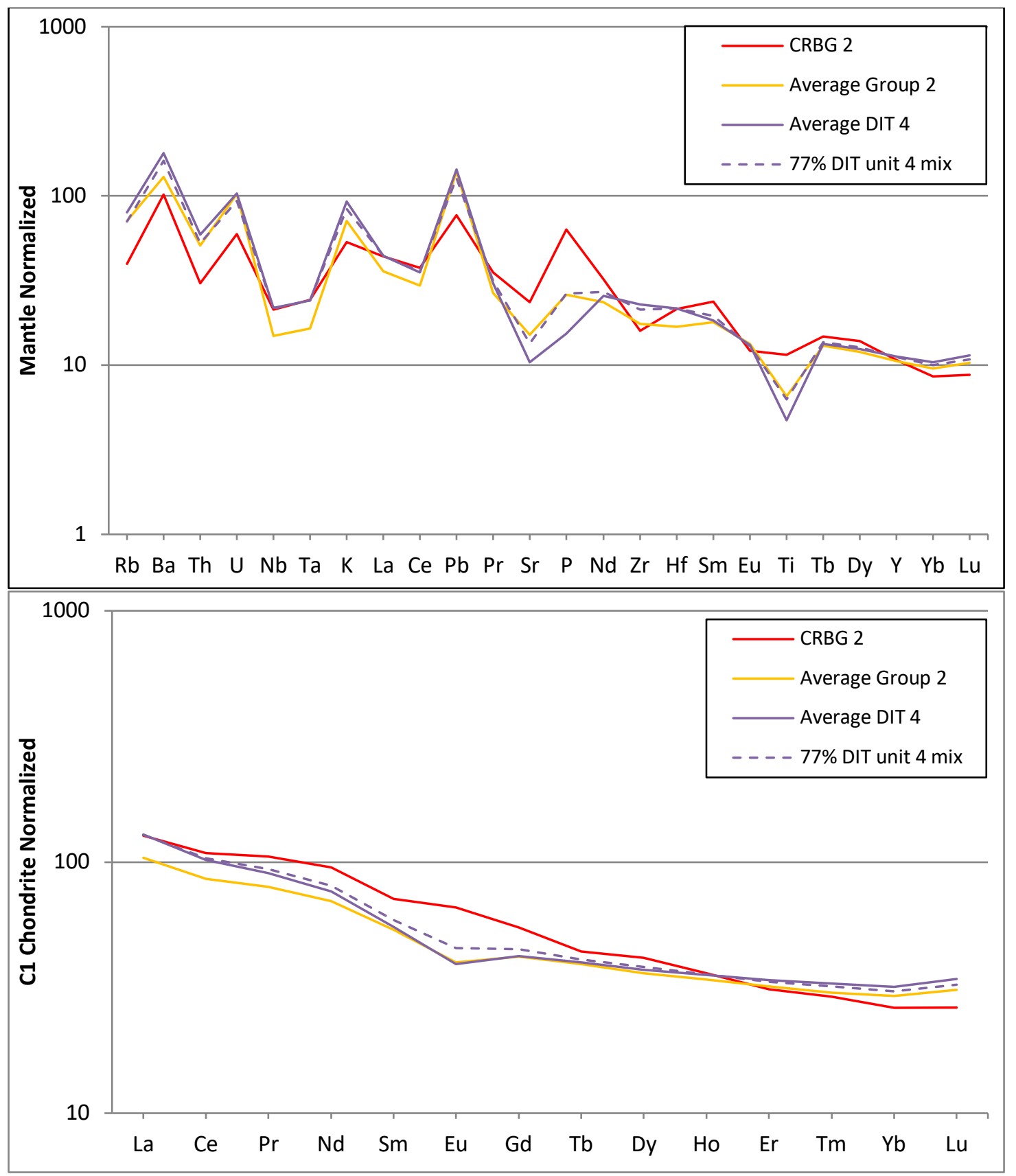

Figure 34. Primitive mantle normalized (Sun and McDonough, 1989) trace element diagram and C1 chondrite (McDonough and Sun, 1995) normalized REE diagram for mixing results of CRBG mafic endmember (determined by linear regression of group 2 icelandite concentrations) with DIT unit 4 to generate group 2 compositions. (see Appendix E for compositions of mixing model)

This requires a high level of felsic material to have mixed with the Grande Ronde type mafic endmember in order to produce the icelandites which is not likely to occur naturally. The major element concentrations that are produced by the mixing of the 
Group 2 mafic endmember with Dinner Creek Unit 4 quickly exceeded the 59-63\% range of $\mathrm{SiO}_{2}$ prior to achieving the necessary trace element enrichment levels of group 2 . The fit also has several misfits in important elements including $\mathrm{Ba}, \mathrm{Nb}-\mathrm{Ta}, \mathrm{Zr}-\mathrm{Hf}$, and rare earth elements La-Nd as well as the major element concentrations produced from the model.-These factors led to the determination that DIT unit 4 was also not the most likely endmember to have mixed with a mafic endmember and produce the group 2 icelandites and that Dinner Creek Tuff unit 3 has the highest probability to have mixed with the group 2 mafic endmember to produce the group 2 icelandites.

\section{REGIONAL DISTRIBUTION}

Geochemical data acquired from previous work and the data produced from this study have shown that mid Miocene icelandites are closely related in space and time to the Grande Ronde Basalt main phase member of the CRBG. The data produced in this study also support the idea that the Hunter Creek Basalt is equivalent to late-stage Grande Ronde lavas in the Malheur River Gorge and vicinity. Both, Webb (2017) and Cruz (2017), posited sources of the erupted icelandite lavas in their geographic study areas (Figure 35). It is feasible that both of these source regions in the Malheur Gorge and Ironside Mountain for the icelandites are possible. The mixing models between the mafic and rhyolitic members have shown that the two groups of icelandites had slightly different mafic endmembers and that they also required different rhyolitic endmembers in order to achieve a mixture that resembled the geochemical signature seen in the data. In the area around Castle Rock Caldera and Ironside Mountain, the majority of the 
icelandite rocks are found stratigraphically above Dinner Creek Tuff unit 2 and below Dinner Creek Unit 4.

The model for the mixing of the GRB-type basaltic endmember for group 2 with the Dinner Creek Tuff unit 3 rhyolitic endmember is the closest match for producing the icelandites of group 2. This is supported by the stratigraphic positioning of the icelandites in the vicinity of Ironside Mountain which was proposed by Cruz (2017) and a possible source region of the icelandites. This idea could also be applied to generation of the group 1 icelandites from mixing of the GRB-type basaltic endmember for group 1 and Upper Littlefield Rhyolite. In this case the icelandites reside stratigraphically above the lower Littlefield Rhyolite and below the upper Littlefield rhyolite.

It has been previously shown that the Grande Ronde Basalt and Hunter Creek Basalt share a connection with the Littlefield rhyolite and Dinner Creek Tuff through stratigraphic position within the areas of emplacement shared between the units and the shared timing of emplacement (Streck et al., 2015; Webb et al, 2018). The geochronological and stratigraphic information on icelandites shows that icelandites erupted at the end of Grande Ronde Basalt activity around 16 Ma to slightly later around $>15 \mathrm{Ma}$ (Table 5). The ages of icelanditic components that were recorded as eruptive components of the Buchanan Tuff (15.1 Ma), Dinner Creek Tuff Unit 4 and Wildcat Creek Tuff (15.5 Ma) also lend support to the idea that these icelandites emplaced at some point before these units were erupted. 
Other studies have revealed the existence of mid Miocene icelandites south of the studied area and thus should be included in the total distribution area of mid Miocene icelandites.

Table 5. Selected ages of mid-Miocene icelanditic units and components.

\begin{tabular}{|c|c|c|c|}
\hline Unit & Reported Age (Ma) & $\begin{array}{l}\text { Stratigraphic } \\
\text { Age }\end{array}$ & Source of age \\
\hline $\begin{array}{c}\text { Icelanditic component of } \\
\text { Buchanan Tuff }\end{array}$ & 15.1 & & $\begin{array}{c}\text { Vranizan and Streck, } \\
\text { GSA Cordilleran } \\
2018\end{array}$ \\
\hline $\begin{array}{l}\text { Icelanditic component of } \\
\text { Dinner Creek Unit } 4\end{array}$ & 15.2 & & $\begin{array}{c}\text { Streck and } \\
\text { Mclntosh, unpubl. }\end{array}$ \\
\hline $\begin{array}{l}\text { Icelanditic component of } \\
\text { Wildcat Creek Tuff }\end{array}$ & 15.5 & & Sales, 2017 \\
\hline Icelandite of Alder Creek & $>16.05$ and $<16.1$ & & Webb et al., 2018 \\
\hline $\begin{array}{c}\text { Icelandites at Ironside } \\
\text { Mountain }\end{array}$ & & $>15.5$ & Cruz, 2017 \\
\hline Icelandites at Castle Rock & & $>15.5$ & Cruz, 2017 \\
\hline $\begin{array}{l}\text { Fiddler's Hell icelandite of } \\
\text { Indian Rock }\end{array}$ & $15.54 \pm 0.10$ & & $\begin{array}{c}\text { Ferns and } \\
\text { McConnell, } 2005\end{array}$ \\
\hline $\begin{array}{l}\text { tholeiitic andesite capping } \\
\text { flows at Lambing Canyon }\end{array}$ & $15.17 \pm 0.18$ & & $\begin{array}{l}\text { Brueseke and Hart, } \\
2007\end{array}$ \\
\hline
\end{tabular}




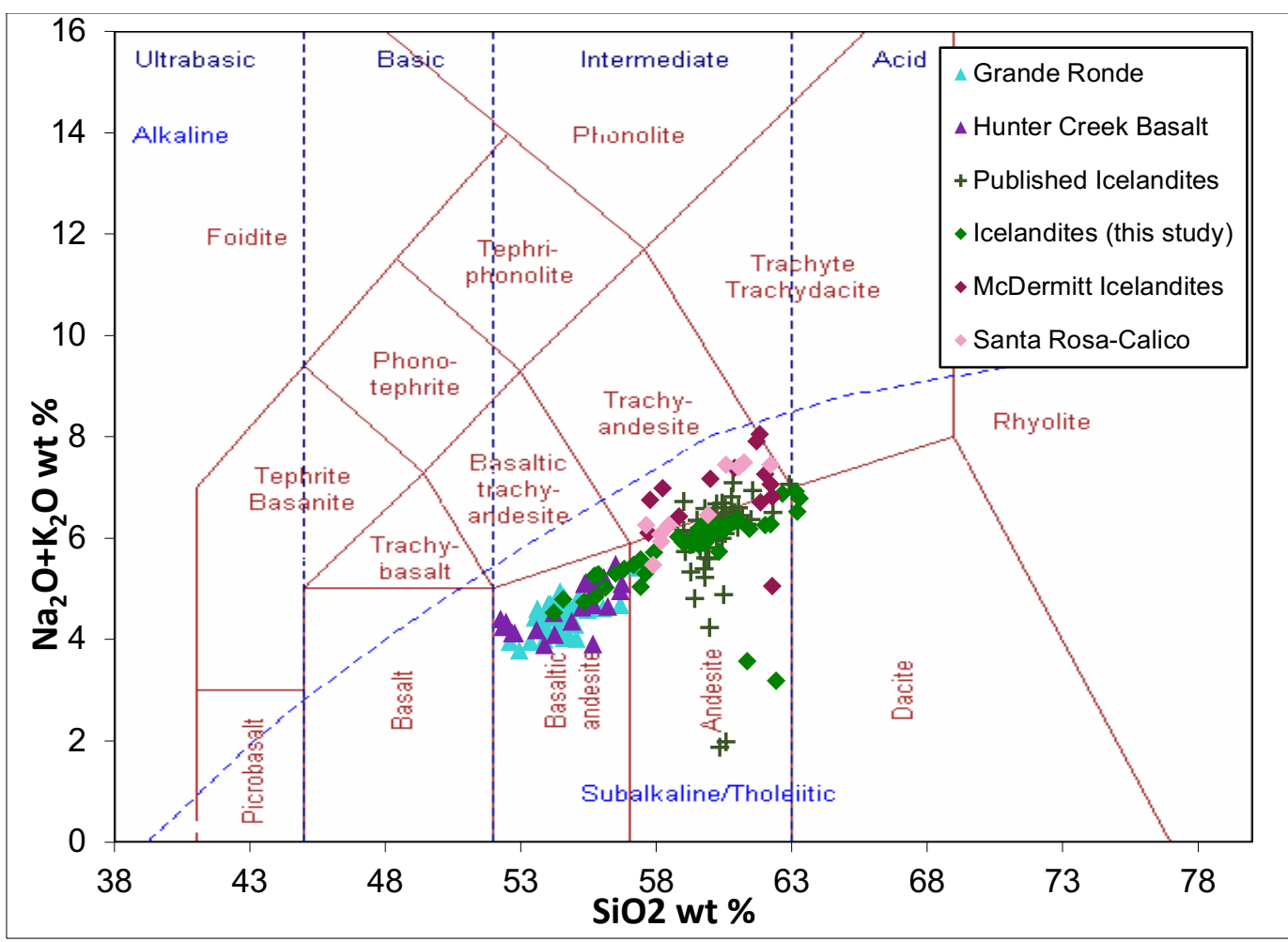

Figure 35. Plot of total alkali versus silica content mid-Miocene icelandites of this study, capping andesites of Folly Farm West, icelanditic rocks of the McDermitt Volcanic Field, and icelanditic rocks of the Santa Rosa-Calico Volcanic Field. Analyses are from this study, Brueseke and Hart (2007) and Brueseke et al. (2009), and Starkel (2014). 


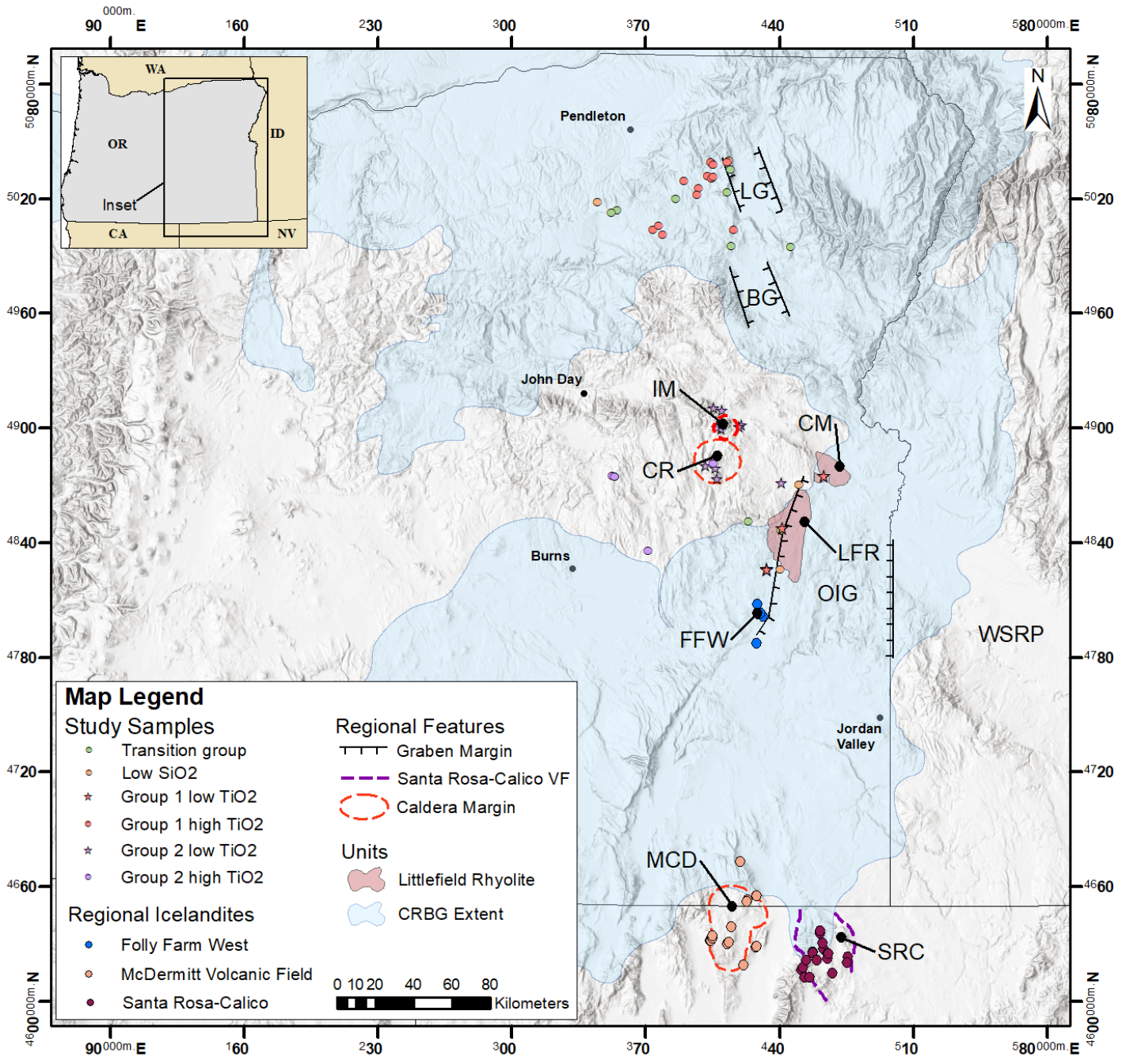

Figure 36. Regional distribution of icelandites including those of this study, FFW-tholeiitic andesites of Folly Farm West in Lambing Canyon, MCD-icelandites of the McDermitt Volcanic Field, SRC-icelandites of Santa Rosa-Calico Volcanic Field. Regional features are as follows: WA-Washington; OR-Oregon; IDIdaho; LG-La Grande graben; BG-Baker graben; OIG-Oregon-Idaho graben; CR-Castle Rock Caldera; SM-Strawberry Volcanics; IM-Ironside Mountain; LFR-Littlefield Rhyolite; CM-Rhyolite of Cottonwood Mountain; WSRP-Western Snake River Plain.

The extended distribution of icelandites includes the tholeiitic capping andesites at Lambing Canyon in Folly Farm West of Brueseke and Hart (2007). The capping andesites of Lambing Canyon have a similar icelanditic geochemical signature to the icelandites of this study, and the age of the unit (Figures 35, 37-39) (Table 3) is also similar to those of this study. Additionally, reports of similar rocks to those found at the top of Lambing 


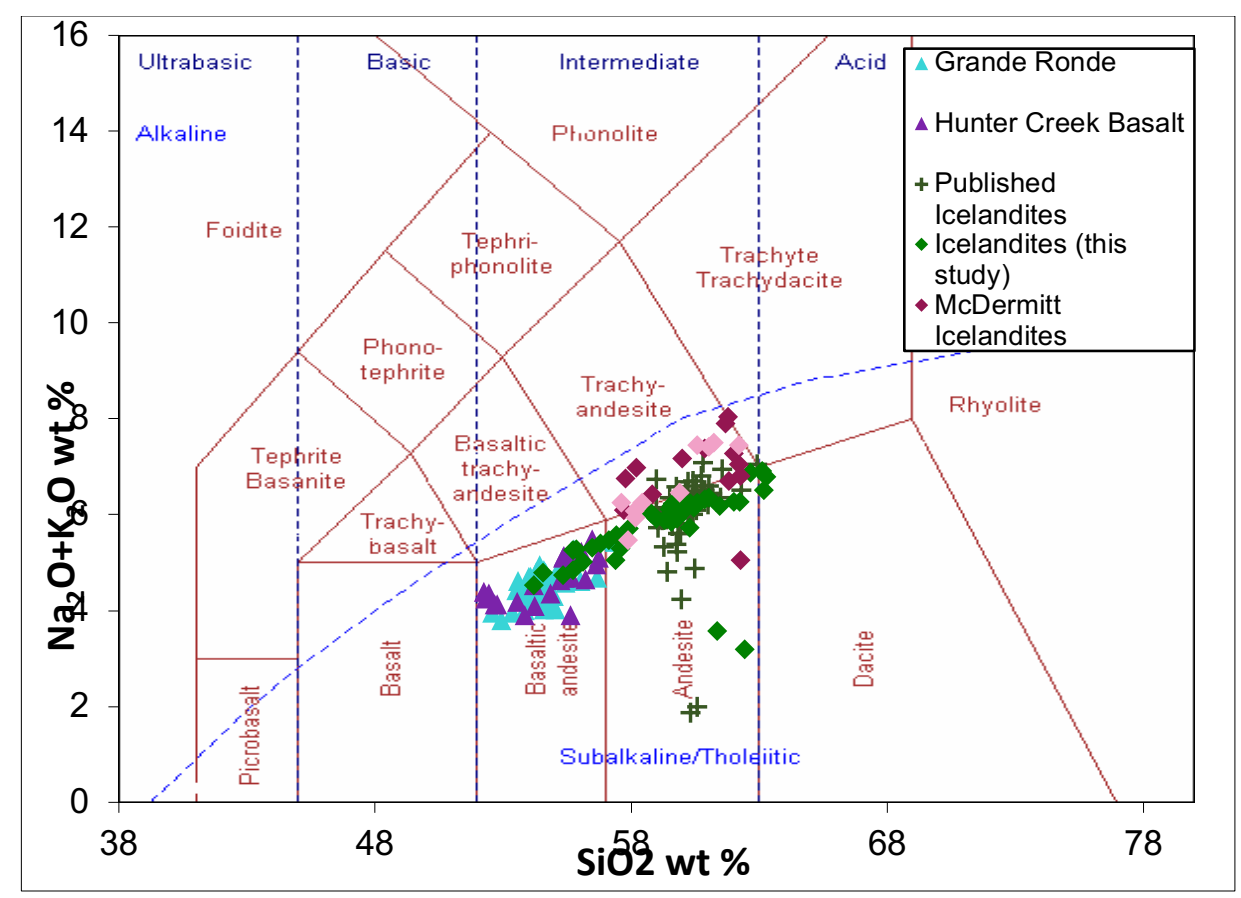

Figure 37. Plot of total alkali versus silica content mid-Miocene icelandites of this study, capping andesites of Folly Farm West, icelanditic rocks of the McDermitt Volcanic Field, and icelanditic rocks of the Santa Rosa-Calico Volcanic Field. Analyses are from this study, Brueseke and Hart (2007) and Brueseke et al. (2009), and Starkel (2014).

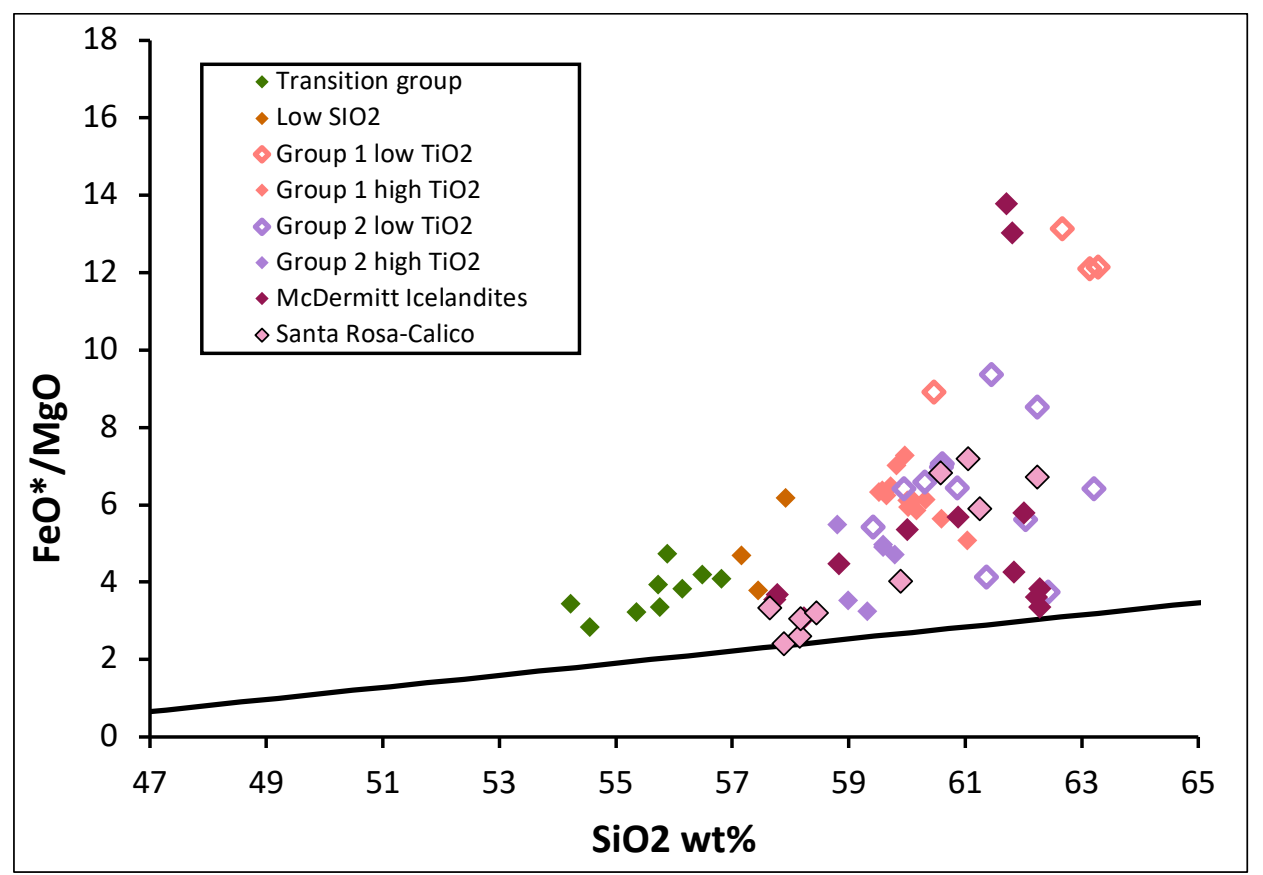

Figure 38. Plot of $\mathrm{FeO} / \mathrm{MgO}$ ratio versus silica content mid-Miocene icelandites of this study, capping andesites of Folly Farm West, icelanditic rocks of the McDermitt Volcanic Field, and icelanditic rocks of the Santa Rosa-Calico Volcanic Field. Analyses are from this study, Brueseke and Hart (2007) and Brueseke et al. (2009), and Starkel (2014). 

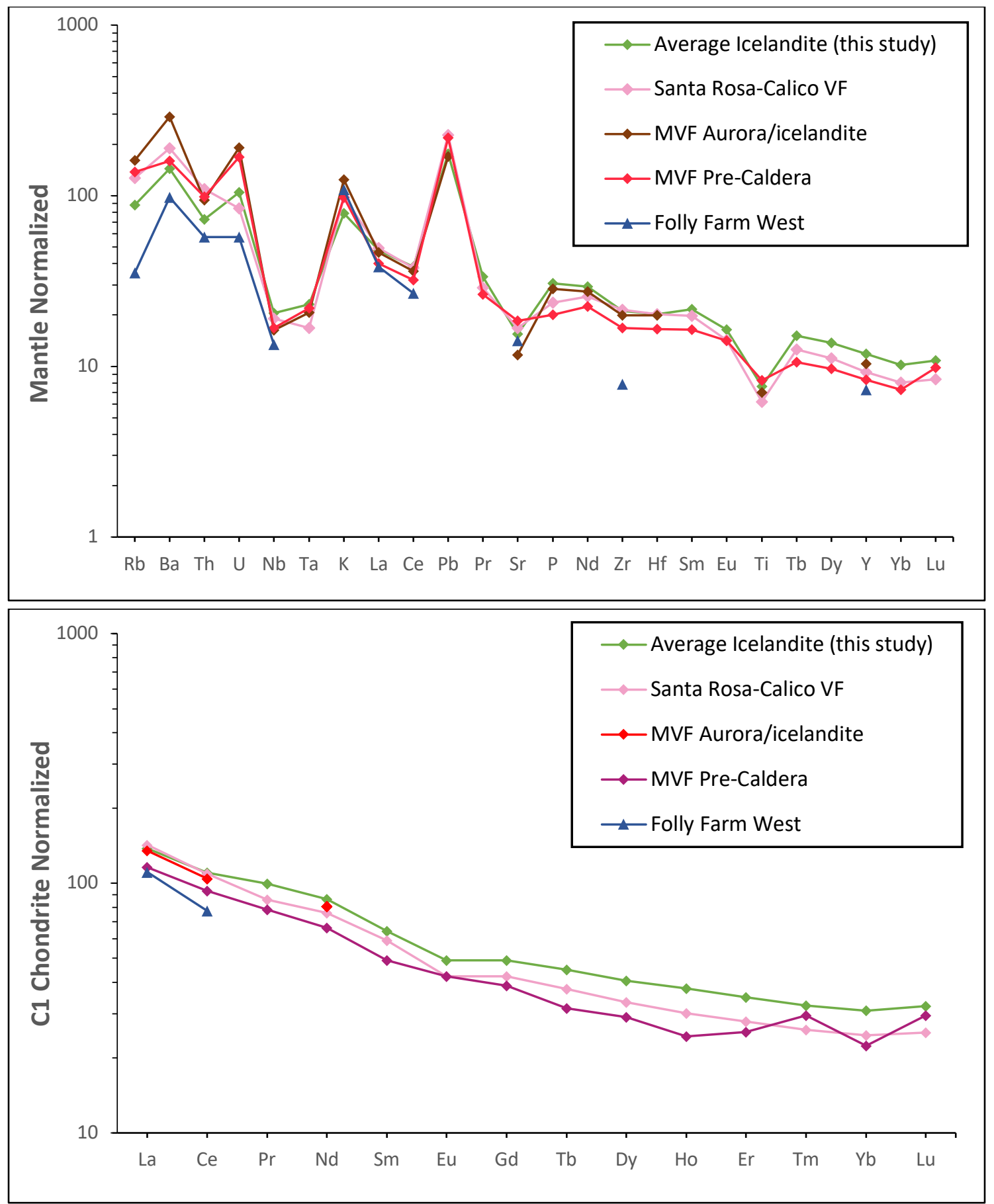

Figure 39. Primitive mantle normalized (Sun and McDonough, 1989) trace element diagram and C1 chondrite (McDonough and Sun, 1995) normalized REE diagram of averaged values of Grande Ronde Basalt, Hunter Creek basalt, icelandites of this study, and icelanditic rocks of the Santa Rosa-Calico Volcanic Field, McDermitt Volcanic Field and tholeiitic andesites of Lambing Canyon in Folly Farm West. 
canyon can also be found in the surrounding area of Steens Mountain and just to the east in the Sheepshead Mountains (M. Brueseke, personal communication). Other icelanditic rocks have been reported by Brueseke et al. (2009) in the Santa Rosa-Calico Volcanic Field. Also, Starkel (2014) reported additional icelanditic rocks, the post caldera Aurora icelandites and lavas as well as several pre caldera intermediate units, in the Mcdermitt Volcanic Field (Figure 37). 


\section{Conclusions}

This study focuses on the distribution, petrology, and geochemistry of mid-Miocene icelandites in eastern Oregon and examines their connection to the Columbia River Basalt Group magmas. Existing research of these rocks is limited and has been restricted to icelandites of the La Grande graben in the northern end of the La Grande-Owyhee eruptive axis and the Oregon-Idaho graben in the south with no work completed in the region in between the two grabens.

The mid-Miocene icelandites discussed in this study erupted of a large part of eastern Oregon and generally correspond to the area from the towns of John Day in the NW, Burns in the SW, La Grande in the NE and Vale in the SE. This area is centered on where all main phase CRBG members overlap along the Malheur Gorge between the towns of Juntura and Vale. This distribution of mid Miocene icelandites is much larger than previously reported. Lithologically, the icelandites of the Fiddlers Hell unit within the La Grande graben, Alder Creek icelandites and the Hunter Creek basalt in the Malheur Gorge are extremely similar when viewed on a macroscopic scale. With the inclusion of other regional mid-Miocene icelandites of Starkel (2015) in McDermitt Volcanic field and those of Brueseke and Hart (2007) and Brueseke et al. (2009), the southern distribution area of mid Miocene icelandites extends into Nevada.

The geochemical signatures of icelandites are distinctly different to main phase CRBG and therefore they should not be incorporated as part of other units as prior work has done with the exception of the Fiddlers Hell unit, but instead these rocks should be treated as its own unit. The icelandites themselves form two groups with each forming 2 
subgroups based on the concentration of numerous trace elements including REE as well as the major elements Al and Ti. Group 1 consists of samples that are more enriched in incompatible trace elements while Group 2 samples are less enriched. Both Groups indicate a high and lower Ti group. The preferred petrologic models to explain icelandites is mixing between a Grande Ronde-like mafic endmember with a rhyolitic endmember, although group 1 and 2 require different mafic and silicic endmembers. Group 1 icelandites require a more enriched mafic and silicic endmember, while Group 2 require less enriched endmembers. The results of the group 1 model show that the upper Littlefield rhyolite has the highest probability of having mixed with the mafic endmember to create the group 1 icelandites. The results of the group 2 model show a high probability of having been the result of a mixture with Dinner Creek Tuff Unit 4. The results of the mixing models also lend support to the idea that the icelandites had at least two main eruptive centers.

This study also shed more light on the mineralogy of these rocks that was not well known compared to the mineralogy of the main phase members of the CRBG. The icelandites are generally aphanitic texturally but they can vary in phenocryst abundance. Previous reports also do not note the presence of apatite in the mineralogy In addition to the spatial proximity among icelandites, CRBG units and mid Miocene rhyolites, this study has also shown a strong geochemical connection between midMiocene rhyolites of eastern Oregon and the Grande Ronde basalt of the CRBG. 


\section{References}

Bailey, D.G., 1990, Geochemistry and Petrogenesis of Miocene Volcanic Rocks in the Powder River Volcanic Field, Northeastern Oregon [Ph.D. dissertation]: Pullman, Washington, Washington State University, $341 \mathrm{p}$.

Bailey, M.M., 1989, Revisions to stratigraphic nomenclature of the Picture Gorge Basalt Subgroup, Columbia River Basalt Group, in Reidel, S.P, and Hooper, P.R., eds., Volcanism and Tectonism in the Columbia River Flood Basalt Province: Geological Society of America Special Paper 239, p. 67-84.

Barry, T.L., Kelley, S.P., Reidel, S.P., Camp, V.E., Self, S., Jarboe, N.A., Duncan, R.A., and Renne, P.R., 2013, Eruption chronology of the Columbia River Basalt Group, in Reidel, S.P., et al., eds., The Columbia River Flood Basalt Province: Geological Society of America Special Paper 497, p. 45-66, doi: 10.1130 /2013.2497 (02).

Binger, G.B., 1997, The Volcanic Stratigraphy of the Juntura Region, Eastern Oregon [M.S. thesis]: Pullman, Washington, Washington State University, 206 p.

Bougault, H., and Hekinian, R., 1974, Rift Valley in the Atlantic Ocean near $36^{\circ} 50^{\prime} \mathrm{N}$ : petrology and geochemistry of basaltic rocks. Earth and Planetary Science Letters, 24(2), 249-261. https://doi.org/10.1016/0012-821X(74)90103-4

Brooks, H.C., 2006, Preliminary geologic and mineral resources map of the Mormon basin quadrangle, Baker and Malheur Counties, Oregon: Oregon Department of Geology and Mineral Industries Open-File O-06-25, scale 1:24,000. 
Brooks, H.C., 1992. Preliminary geologic map of the Copeland Reservoir quadrangle. Malheur County, Oregon: Oregon Department of Geology and Mineral Industries Open-File Report 0-93-3, scale, 1, pp.24-000.

Brooks, H.C., and O'Brien, J.P., 1992a, Geology and mineral resources map of the Little Valley quadrangle, Malheur County, Oregon: Oregon Department of Geology and Mineral Industries Geologic Map Series GMS-72, 1 sheet, scale 1:24,000.

Brooks, H.C., and O'Brien, J.P., 1992b, Geology and mineral resources map of the Westfall quadrangle, Malheur County, Oregon: Oregon Department of Geology and Mineral Industries Geologic Map Series GMS-71, 1 sheet, scale 1:24,000.

Brueseke, M.E. and Hart, W.K., 2009, Intermediate composition magma production in an intracontinental setting: Unusual andesites and dacites of the mid-Miocene Santa Rosa-Calico volcanic field, northern Nevada. Journal of Volcanology and Geothermal Research, 188(1-3), pp.197-213.

Brueseke, M.E., Heizler, M.T., Hart, W.K., and Mertzman, S.A., 2007, Distribution and geochronology of Oregon Plateau (U.S.A.) flood basalt volcanism: The Steens Basalt revisited: Journal of Volcanology and Geothermal Research, v. 161, no. 3, p. 187-214, doi:10.1016/j.jvolgeores.2006.12.004.

Brunet, F., and Chazot, G., 2001, Partitioning of phosphorus between olivine, clinopyroxene and silicate glass in a spinel Iherzolite xenolith from Yemen. 
Chemical Geology, 176(1-4), 51-72. https://doi.org/10.1016/S00092541(00)00351-X

Cahoon, E.B., 2020. Distribution, Geochronology, and Petrogenesis of the Picture Gorge Basalt with Special Focus on Petrological Relationships to the Main Columbia River Basalt Group. [Ph.D Dissertation]: Portland, Oregon, Portland State University, $181 \mathrm{p}$.

Camp, V.E., 2013, Origin of Columbia River Basalt: Passive rise of shallow mantle, or active upwelling of a deep-mantle plume?, in Reidel, S.P., Camp, V.E., Ross, M.E., Wolff, J.A., Martin, B.S., Tolan, T.L., and Wells, R.E., eds., The Columbia River Flood Basalt Province, Volume 497, Geological Society of America Special Paper, p. 181-199.

Camp, V.E., and Ross, M.E., 2004, Mantle dynamics and genesis of mafic magmatism in the intermontane Pacific Northwest: Journal of Geophysical Research, v. 109, $14 p$.

Camp, V.E., Ross, M.E., and Hanson, W.E., 2003, Genesis of flood basalts and Basin and Range volcanic rocks from Steens Mountain to the Malheur River Gorge, Oregon: Geological Society of America Bulletin, v. 115, no. 1, p. 105-128.

Carlson, R.W., and Hart, W.K., 1987, Crustal genesis on the Oregon Plateau: Journal of Geophysical Research, v. 92, no. B7, 6191-6206, doi:10.1029/JB092iB07p06191. 
Carmichael, I. S. E., 1964, The petrology of Thingmuli, a Tertiary volcano in eastern Iceland: Journal of Petrology, v. 5, part 3, p. 435-460.

Cruz, M., 2017. Field Mapping Investigation and Geochemical Analysis of Volcanic Units within the Dinner Creek Tuff Eruptive Center, Malheur County, Eastern Oregon. [Master's Thesis]: Portland, Oregon, Portland State University, 217 p.

Cummings, M.L., Evans, J.G., Ferns, M.L., and Lees, K.R., 2000, Stratigraphic and structural evolution of the middle Miocene synvolcanic Oregon-Idaho graben: Geological Society of America Bulletin, v. 112, p. 668-682.

Dunn, T., and Sen, C., 1994, Mineral/matrix partition coefficients for orthopyroxene, plagioclase, and olivine in basaltic to andesitic systems: A combined analytical and experimental study. Geochimica et Cosmochimica Acta, 58(2), 717-733. https://doi.org/10.1016/0016-7037(94)90501-0

Edwards, J.H., 2013, Structural Controls of the Neal Hot Springs Geothermal System, Eastern Oregon [M.S. Thesis]: University of Nevada, Reno, Nevada, 92 p.

ESRI. (2020, May 12). ArcGIS 10.8.1.

Ewart, A., and Griffin, W.L., 1994, Application of proton-microprobe data to traceelement partitioning in volcanic rocks: Chemical Geology, v. 117, p. 251-284, doi:10.1016/0009-2541(94)90131-7. 
Evans, J.G., and Binger, G.B., 1999c, Geologic map of the Alder Creek quadrangle, Malheur County, Oregon: U.S. Geological Survey Open-File Report 98-494, 12 p., 1 sheet, scale 1:24,000, https:// doi .org /10 .3133 /ofr98494 .

Ferns, M.L., Streck, M.J. and McClaughry, J.D., 2017. Field-trip guide to Columbia River flood basalts, associated rhyolites, and diverse post-plume volcanism in eastern Oregon (No. 2017-5022-O). US Geological Survey.

Ferns, M.L., and McClaughry, J.D., 2013, Stratigraphy and volcanic evolution of the middle Miocene to Pliocene La Grande-Owyhee eruptive axis in eastern Oregon, in Reidel, S.P., et al., eds., The Columbia River Flood Basalt Province: Geological Society of America Special Paper 497, p. 401-427, doi: 10.1130 /2013.2497 (16).

Ferns, M.L., McConnell, V.S., Madin, I.P., and Johnson, J.J., 2010, Geology of the Upper Grande Ronde Basin, Union County, Oregon: Oregon Department of Geology and Mineral Industries Bulletin 107, map scale 1:100,000.

Ferns, M.L., and McConnell, V.S., 2005, Geoanalytical Information Layer for Oregon, Release 1: Oregon Department of Geology and Mineral Industries Digital Data Series GILO-1 (on CD-ROM).

Ferns, M.L., and O'Brien, J.P., 1992a, Geology and mineral resources map of the Namorf quadrangle, Malheur County, Oregon: Oregon Department of Geology and Mineral Industries Geologic Map Series GMS-74, 1 sheet, scale 1:24,000. 
Ferns, M.L., and O'Brien, J.P., 1992b, Geology and mineral resources map of the Harper quadrangle, Malheur County, Oregon: Oregon Department of Geology and Mineral Industries Geologic Map Series GMS-69, 1 sheet, scale 1:24,000.

Ferns, M.L., 1989a, Geology and mineral resources map of the Graveyard Point quadrangle, Malheur County, Oregon, and Owyhee County, Idaho: Oregon Department of Geology and Mineral Industries Geological Map Series GMS-54, scale 1:24,000.

Ferns, M.L., 1989b, Geology and mineral resources map of the Owyhee Ridge quadrangle, Malheur County, Oregon: Oregon Department of Geology and Mineral Industries Geological Map Series GMS-53, scale 1:24,000.

Fujimaki, H., 1986, Partition coefficients of Hf, Zr, and REE between zircon, apatite, and liquid. Contributions to Mineralogy and Petrology, 94(1), pp.42-45.

Gill, 1981, "Orogenic andesites and plate tectonics": Berlin-New York, Springer-Verlag, p. 160-163.

Green, T.H., Blundy, J.D., Adam, J., and Yaxley, G.M., 2000, SIMS determination of trace element partition coefficients between garnet, clinopyroxene and hydrous basaltic liquids at 2-7.5 GPa and $1080-1200^{\circ} \mathrm{C}$ : Lithos, v. 53, p. 165-187, doi:10.1016/S0024-4937(00)00023-2. 
Green, J.C. and Fitz III, T.J., 1993. Extensive felsic lavas and rheoignimbrites in the Keweenawan Midcontinent Rift plateau volcanics, Minnesota: petrographic and field recognition. Journal of Volcanology and Geothermal Research, 54(3-4), pp.177-196.

Green, T.H., Sie, S.H., Ryan, C.G., and Cousens, D.R., 1989, Proton microprobedetermined partitioning of $\mathrm{Nb}, \mathrm{Ta}, \mathrm{Zr}$, Sr and $\mathrm{Y}$ between garnet, clinopyroxene and basaltic magma at high pressure and temperature: Chemical Geology, v. 74, p. 201-216, doi:10.1016/0009-2541(89)90032-6.

Hart, Stanley R., and Todd Dunn., 1993, “Experimental Cpx/Melt Partitioning of 24 Trace Elements." Contributions to Mineralogy and Petrology 113 (1): 1-8.

Hooper, P.R., Binger, B.G., and Lees, K.L., 2002, Vale Project Analyses: Whole Rock Major and Trace Element Analysis by XRF. GeoAnalytical Laboratory, Washington State University. (Samples collected by Jim Evans, Mark Ferns, Howard Brooks, Jenda Johnson, Kate Lees, Mandi Francis, Ben Binger, Chris Hawkesworth, and Peter Hooper.)

Hooper, P.R., Binger, G.G., and Lees, K.R., 2002a, Ages of the Steens and Columbia River flood basalts and their relationship to extension-related calc-alkalic volcanism in eastern Oregon: Geological Society of America Bulletin, v. 114, no. 1, p. 43-50, doi:10.1130/0016-7606(2002) 114<0043:AOTSAC>2.0.CO;2. 
Hooper, P. R., 2000, Chemical discrimination of Columbia River basalt flows:

Geochemistry, Geophysics, and Geosystems, v. 1, no. 6, 1024, doi:10.1029/2000GC000040.

Hooper P. R., Hawkesworth C. J., 1993, Isotopic and geochemical constraints on the origin and evolution of the Columbia River Basalt: Journal of Petrology, v. 34, p. 203-1246.

Hooper, P.R., and Swanson, D.A., 1990, The Columbia River Basalt Group and associated volcanic rocks of the Blue Mountains Province, in Walker, G.W., ed., Geology of the Blue Mountains Region of Oregon, Idaho, and Washington: Cenozoic Geology of the Blue Mountains Region: U.S. Geological Survey Professional Paper 1437, p. 63-99.

Irvine, T.N., and Baragar, W.R.A., 1971, A guide to the chemical classification of the common volcanic rocks: Canadian Journal of Earth Sciences, v. 8, p. 523-548.

Jang, Y.D., and Naslund, H.R., 2003, Major and trace element variation in ilmenite in the Skaergaard Intrusion: Petrologic implications: Chemical Geology, v. 193, p. 109125, doi:10.1016/S0009-2541(02)00224-3.

Jarboe, N.A., Coe, R.S., Renne, P.R., and Glen, J.M.G., 2010, The age of the Steens reversal and the Columbia River Basalt Group: Chemical Geology, v. 274, p. 159168. 
Jónasson, K., Holm, P.M., and Pedersen, A.K., 1992. Petrogenesis of silicic rocks from the Króksfjördur central volcano, NW Iceland. Journal of Petrology, 33(6), pp.13451369.

Kittleman, L.R., Green, A.R., Haddock, G.H., Hagood, A.R., Johnson, A.M., McMurray, J.M., Russell, R.G., and Weeden, D.A., 1967, Geologic map of the Owyhee region, Malheur County, Oregon: Eugene, University of Oregon Museum of Natural History Bulletin 8, scale 1:125 000.

Kittleman, L.R., Green, A.R., Hagood, A.R., Johnson, A.M., McMurray, J.M., Russell, R.G., and Weeden, D.A., 1965, Cenozoic stratigraphy of the Owyhee region, southeastern Oregon: Eugene, University of Oregon Museum of Natural History Bulletin 1, $45 \mathrm{p}$.

Klemme, S., Günther, D., Hametner, K., Prowatke, S., and Zack, T., 2006, The partitioning of trace elements between ilmenite, ulvospinel, armalcolite and silicate melts with implications for the early differentiation of the moon. Chemical Geology, 234(3-4), 251-263. https://doi.org/10.1016/j.chemgeo.2006.05.005

Kloeck, W. and Palme, H., 1988, Proceedings of the Lunar and Planetary Science Conference. In Proceedings of the Lunar and Planetary Science Conference (Vol. 18, pp. 471-483).

Korosec, M.A., 1987, Geologic map of the Hood River Quadrangle, Washington and Oregon, doi:10.2172/6464338. 
Lambert, R.S., Chamberlain, V.E. and Holland, J.G., 1995. Ferro-andesites in the Grande Ronde Basalt: their composition and significance in studies of the origin of the Columbia River Basalt Group. Canadian Journal of Earth Sciences, 32(4), pp.424436.

Langmuir, C.H., Vocke Jr, R.D., Hanson, G.N. and Hart, S.R., 1978, A general mixing equation with applications to Icelandic basalts. Earth and Planetary Science Letters, 37(3), pp.380-392.

Laubier, M., Grove, T.L., and Langmuir, C.H., 2014, Trace element mineral/melt partitioning for basaltic and basaltic andesitic melts: An experimental and laser ICP-MS study with application to the oxidation state of mantle source regions: Earth and Planetary Science Letters, v. 392, p. 265-278, doi:10.1016/j.epsl.2014.01.053.

Le Bas, M.J., Le Maitre, R.W., Streckeisen, A., and Zanettin, B., 1986, A chemical classification of volcanic rocks based on the total alkali - silica diagram: Journal of Petrology, v. 27, p. 745-750.

Lemarchand, F., Villemant, B. and Calas, G., 1987, Trace element distribution coefficients in alkaline series. Geochimica et Cosmochimica Acta, 51(5), pp.1071-1081.

Lees, K.R., 1994, Magmatic and Tectonic Changes through Time in the Neogene Volcanic Rocks of the Vale Area, Oregon, Northwestern USA [Ph.D. thesis]: Milton Keynes, UK, The Open University-Milton Keynes, 282 p. 
Ma, L., Madin, I.P., Olson, K.V., and Watzig, R.J., 2009, Oregon Geological Data Compilation: Oregon Department of Geology and Mineral Industries, v. 5.

MacLeod, N.S., 1990a, Geology and mineral resources map of the Mahogany Gap Quadrangle, Malheur County, Oregon: Oregon Department of Geology and Mineral Industries Geological Map Series GMS-65, scale 1:24 000.

Madin, I.P., 1997, Geologic Map of the Tucker Flat Quadrangle, Union and Baker Counties, Oregon: Oregon Department of Geology and Mineral Industries Geological Map Series GMS-110, 9 p., scale 1:24,000.

Mancini, A., Mattsson, H.B. and Bachmann, O., 2015. Origin of the compositional diversity in the basalt-to-dacite series erupted along the Heiðarsporður ridge, NE Iceland. Journal of Volcanology and Geothermal Research, 301, pp.116-127.

Matsui, Y., N. Onuma, H. Nagasawa, H. Higuchi, and S. Banno., 1977, “Crystal Structure Control in Trace Element Partition between Crystal and Magma." Bulletin de La Societe Francaise de Mineralogie et de Cristallographie 100 (6): 315-24.

McDonough, W.F., and Sun, S.S., 1995, The composition of the Earth: Chemica Geology, v. 120 , p. $223-253$. 
McKay, Gordon A., Jerry Wagstaff, and S. R. Yang., 1986, “Zirconium, Hafnium, and Rare Earth Element Partition Coefficients for Ilmenite and Other Minerals in High-Ti Lunar Mare Basalts; an Experimental Study." Journal of Geophysical Research 91 (B4): D229-37. doi:10.1029/JB091iB04p0D229.

McKenzie, Dan, and R. K. O’Nions., 1991, “Partial Melt Distributions from Inversion of Rare Earth Element Concentrations." Journal of Petrology 32 (5): 1021-91.

Mysen, B. O., 1978, “Experimental Determination of Nickel Partition Coefficients between Liquid, Pargasite, and Garnet Peridotite Minerals and Concentration Limits of Behavior According to Henry's Law at High Pressure and Temperature." American Journal of Science 278 (2): 217-43.

Nielsen, R. L., Gallahan, W. E., and Newberger, F., 1992, Experimentally determined mineral-melt partition coefficients for Sc, Y and REE for olivine, orthopyroxene, pigeonite, magnetite and ilmenite. Contributions to Mineralogy and Petrology, 110(4), 488-499. https://doi.org/10.1007/BF00344083

Norman, M., Garcia, M.O. and Pietruszka, A.J., 2005, Trace-element distribution coefficients for pyroxenes, plagioclase, and olivine in evolved tholeiites from the 1955 eruption of Kilauea Volcano, Hawai'i, and petrogenesis of differentiated rift-zone lavas. American Mineralogist, 90(5-6), pp.888-899.

Okamoto, K., 1979, Geochemical approach on the magmatic differentiation of Asama volcano and $\mathrm{Cs} / \mathrm{Rb}$ ratios of calc-alkaline rocks in island arcs. 
Oxford Instruments, 2013, AZtec EDS Software

Paster, T.P., Schauwecker, D.S., and Haskin, L.A., 1974, The behavior of some trace elements during solidification of the Skaergaard layered series: Geochimica et Cosmochimica Acta, v. 38, p. 1549-1577, doi:10.1016/0016-7037(74)90174-4.

Philpotts, J.A., and Schnetzler, C.C., 1970, Phenocryst-matrix partition coefficients for K, $\mathrm{Rb}, \mathrm{Sr}$ and $\mathrm{Ba}$, with applications to anorthosite and basalt genesis: Geochimica et Cosmochimica Acta, v. 34, p. 307-322, doi:10.1016/0016-7037(70)90108-0.

Reidel, S.P., Camp, V.E., Tolan, T.L., and Martin, B.S., 2013, The Columbia River flood basalt province: Stratigraphy, areal extent, volume, and physical volcanology, in Reidel, S.P., Camp, V.E., Ross, M.E., Wolff, J.A., Martin, B.S., Tolan, T.L, and Wells, R.E., eds., The Columbia River Flood Basalt Province: Geological Society of America Special Paper 497, doi:10.1130/2013.2497(01).

Reidel, S.P., and Tolan, T.L., 2013, The Grande Ronde Basalt, Columbia River Basalt Group, in Reidel, S.P., et al., eds., The Columbia River Flood Basalt Province: Geological Society of America Special Paper 497, p. 117-153, doi: 10.1130 /2013 $.2497(05)$.

Reidel, S. P. 1998, Emplacement of Columbia River flood basalt: Journal of Geophysical Research, v. 103, issue. B11, p. 27393-27410, doi:10.1029/97JB03671. 
Ringwood, A. E., 1970, “Petrogenesis of Apollo 11 Basalts and Implications for Lunar Origin." Journal of Geophysical Research 75 (32): 6453-79.

Sales, H.J., 2018, The Wildcat Creek Tuff, Eastern Oregon: Co-eruption of Crystal-poor Rhyolite and Fe-rich Andesite with Implication for Mafic Underpinnings to Voluminous A-type Rhyolites, [M.S. thesis]: Portland, Oregon, Portland State University, 151p.

Starkel, W.S., 2014, Mapping, geologic evolution and petrogenesis of the McDermitt caldera center, northern Nevada and southern Oregon, USA [Ph.D. thesis]: Pullman, Washington State University, 393 p.

Streck, M.J., Ferns, M.L., and McIntosh, W.C., 2015, Large, persistent rhyolitic magma reservoirs above Columbia River Basalt storage sites: The Dinner Creek Tuff Eruptive Center, eastern Oregon: Geosphere, v. 11, n. 2, p. 1-10.

Sun, S.S. and McDonough, W.F., 1989, Chemical and isotopic systematics of oceanic basalts: implications for mantle composition and processes: Geological Society, London, Special Publications, v. 42, p. 313-3445.

Swanson, D.A., Wright, T.L., Hooper, P.R., and Bentley, R.D., 1979a, Revisions in Stratigraphic Nomenclature of the Columbia River Basalt Group: U.S. Geological Survey Bulletin 1457-G, 59 p. 
Vervoort, J.D. and Green, J.C., 1997. Origin of evolved magmas in the Midcontinent rift system, northeast Minnesota: Nd-isotope evidence for melting of Archean crust. Canadian Journal of Earth Sciences, 34(4), pp.521-535.

Vranizan, L, Streck, MJ, Mclntosh, WC and Sales, H 2019, 'Composition of mafic fiamme of the rhyolitic Buchanan Tuff, eastern Oregon; understanding magmas that drive silicic magmatism', Abstracts with Programs - Geological Society of America, vol. 51, no. 4, p. Abstract no. 11-17

Webb, B.M., Streck, M.J., McIntosh, W.C., and Ferns, M.L., 2019. The Littlefield Rhyolite and associated mafic lavas: Bimodal volcanism of the Columbia River magmatic province, with constraints on age and storage sites of Grande Ronde Basalt magmas. Geosphere, 15(1), pp.60-84.

Webb, B.M., 2017, The Littlefield Rhyolite, eastern Oregon: Distinct flow units and their constraints on age and storage sites of Grande Ronde Basalt magmas [M.S. thesis]: Portland, Oregon, Portland State University, 164 p., https:// doi .org /10 .15760 /etd .5906 .

Wolff, J.A., and Ramos, F.C., 2013, Source materials for the main phase of the Columbia River Basalt Group: Geochemical evidence and implications for magma storage and transport: Geological Society of America Special Paper 497, p. 273-291. 
Wolff, J.A., Ramos, F.C., Hart, G.L., Patterson, J.D., and Brandon, A.D., 2008, Columbia River flood basalts from a centralized crustal magmatic system: Nature Geoscience, doi:10.1038/ngeo124.

Wright, T.L., Black, K.N., Swanson, D.A., and O’Hearn, T., 1980, Columbia River Basalt; 1978-1979 sample data and chemical analyses, doi:10.3133/OFR80921.

Wright, T.L., 1979. Major oxide, trace element, and glass chemistry of Columbia River basalt samples collected between 1971 and 1977 (Vol. 79, No. 711). US Geological Survey.

Zimmerman, B.S., 1991, Geology and Geochemistry of Epithermal Gold Mineralization in the Lake Owyhee Volcanic Field-Western Snake River Plain Region of Eastern Oregon and Western Idaho [Ph.D. thesis]: Pullman, Washington, Washington State University, 262 p. 


\section{Appendix A: Whole Rock Geochemical Data}

Table A-1. XRF and ICP-MS geochemical data.

\begin{tabular}{|c|c|c|c|c|c|}
\hline Sample ID & MAC-17-02 & MAC-17-03 & MAC-17-04a & MAC-17-05 & MAC-17-06 \\
\hline Dataset & Carley, 2017 & Carley, 2017 & Carley, 2017 & Carley, 2017 & Carley, 2017 \\
\hline Unit & Fiddler's Hell & Fiddler's Hell & Fiddlers Hell & Fiddler's Hell & Fiddler's Hell \\
\hline $\begin{array}{l}\text { Icelandite } \\
\text { Group }\end{array}$ & Transition & Transition & $\begin{array}{c}\text { Group } 1 \text { high } \\
\text { TiO2 }\end{array}$ & $\begin{array}{l}\text { Group } 1 \text { high } \\
\text { TiO2 }\end{array}$ & $\begin{array}{c}\text { Group } 1 \text { high } \\
\text { TiO2 }\end{array}$ \\
\hline Quad & $\begin{array}{c}\text { Granite } \\
\text { Meadows }\end{array}$ & Ukiah & $\begin{array}{l}\text { Sullivan's } \\
\text { Gulch }\end{array}$ & $\begin{array}{l}\text { Sullivan's } \\
\text { Gulch }\end{array}$ & $\begin{array}{l}\text { Sullivan's } \\
\text { Gulch }\end{array}$ \\
\hline Easting (m) & 354745.94 & 352029.02 & 373668.06 & 378729.88 & 376393.40 \\
\hline Northing $(m)$ & 5013971.89 & 5012429.15 & 5003693.36 & 5000957.13 & 5005731.80 \\
\hline \multicolumn{6}{|c|}{ XRF Normalized Wt. \% } \\
\hline $\mathrm{SiO2}$ & 55.35 & 55.75 & 60.16 & 59.65 & 60.10 \\
\hline TiO2 & 2.24 & 2.36 & 1.97 & 1.96 & 1.96 \\
\hline Al2O3 & 13.85 & 13.61 & 13.35 & 13.23 & 13.33 \\
\hline $\mathrm{FeO} *$ & 11.77 & 11.80 & 10.20 & 10.78 & 10.29 \\
\hline MnO & 0.21 & 0.22 & 0.23 & 0.28 & 0.22 \\
\hline MgO & 3.65 & 3.51 & 1.74 & 1.72 & 1.68 \\
\hline $\mathrm{CaO}$ & 7.79 & 7.45 & 5.36 & 5.35 & 5.39 \\
\hline $\mathrm{Na2O}$ & 3.20 & 3.18 & 3.52 & 3.36 & 3.41 \\
\hline K2O & 1.54 & 1.66 & 2.68 & 2.88 & 2.84 \\
\hline P2O5 & 0.41 & 0.476 & 0.798 & 0.792 & 0.784 \\
\hline
\end{tabular}

XRF Trace (ppm)

\begin{tabular}{lccccc}
$\mathrm{Ni}$ & 8 & 9 & 4 & 6 & 3 \\
$\mathrm{Cr}$ & 9 & 7 & 0 & 1 & 0 \\
$\mathrm{Sc}$ & 35 & 35 & 26 & 26 & 26 \\
$\mathrm{~V}$ & 327 & 308 & 51 & 49 & 52 \\
$\mathrm{Ba}$ & 665 & 723 & 1117 & 1247 & 1027 \\
$\mathrm{Rb}$ & 39 & 41 & 64 & 64 & 65 \\
$\mathrm{Sr}$ & 331 & 331 & 325 & 333 & 329 \\
$\mathrm{Zr}$ & 185 & 195 & 263 & 260 & 263 \\
$\mathrm{Y}$ & 41 & 44 & 60 & 56 & 56 \\
$\mathrm{Nb}$ & 13.1 & 13.7 & 18.6 & 18.1 & 17.6 \\
$\mathrm{Ga}$ & 22 & 22 & 23 & 22 & 23 \\
$\mathrm{Cu}$ & 18 & 14 & 8 & 11 & 7 \\
$\mathrm{Zn}$ & 143 & 152 & 155 & 163 & 162 \\
$\mathrm{~Pb}$ & 13 & 14 & 14 & 15 & 15 \\
$\mathrm{La}$ & 22 & 30 & 40 & 37 & 37 \\
$\mathrm{Ce}$ & 54 & 62 & 83 & 78 & 81 \\
$\mathrm{Th}$ & 4 & 7 & 9 & 8 & 8 \\
$\mathrm{Nd}$ & 28 & 32 & 44 & 44 & 43 \\
$\mathrm{U}$ & 2 & 3 & 2 & 4 & 2 \\
\hline
\end{tabular}




\begin{tabular}{|c|c|c|c|c|c|}
\hline Sample ID & MAC-17-02 & MAC-17-03 & MAC-17-04a & MAC-17-05 & MAC-17-06 \\
\hline Easting $(m)$ & 354745.94 & 352029.02 & 373668.06 & 378729.88 & 376393.40 \\
\hline Northing (m) & 5013971.89 & 5012429.15 & 5003693.36 & 5000957.13 & 5005731.80 \\
\hline Unit & Fiddler's Hell & Fiddler's Hell & Fiddlers Hell & Fiddler's Hell & Fiddler's Hell \\
\hline \multicolumn{6}{|c|}{ ICP-MS Trace (ppm) } \\
\hline La ppm & 24.99 & 28.27 & 40.78 & 39.13 & 37.92 \\
\hline Ce ppm & 51.55 & 57.86 & 82.43 & 81.26 & 79.59 \\
\hline Pr ppm & 6.80 & 7.72 & 10.97 & 10.57 & 10.37 \\
\hline Nd ppm & 29.13 & 32.81 & 46.55 & 44.75 & 44.07 \\
\hline Sm ppm & 7.10 & 8.06 & 11.20 & 10.75 & 10.69 \\
\hline Eu ppm & 2.31 & 2.55 & 3.25 & 3.16 & 3.12 \\
\hline Gd ppm & 7.57 & 8.40 & 11.60 & 11.04 & 10.81 \\
\hline Tb ppm & 1.27 & 1.40 & 1.88 & 1.79 & 1.75 \\
\hline Dy ppm & 7.71 & 8.60 & 11.52 & 10.99 & 10.59 \\
\hline Ho ppm & 1.58 & 1.74 & 2.34 & 2.24 & 2.16 \\
\hline Er ppm & 4.23 & 4.71 & 6.31 & 5.92 & 5.80 \\
\hline Tm ppm & 0.60 & 0.66 & 0.88 & 0.83 & 0.82 \\
\hline Yb ppm & 3.70 & 4.02 & 5.37 & 5.11 & 5.00 \\
\hline Lu ppm & 0.57 & 0.62 & 0.84 & 0.80 & 0.77 \\
\hline Ba ppm & 656 & 716 & 1114 & 1251 & 1002 \\
\hline Th ppm & 4.88 & 5.08 & 8.13 & 8.09 & 7.94 \\
\hline Nb ppm & 12.60 & 13.48 & 18.01 & 17.82 & 17.47 \\
\hline Y ppm & 41.11 & 44.70 & 60.86 & 56.83 & 55.06 \\
\hline Hf ppm & 4.91 & 5.17 & 7.04 & 7.08 & 6.92 \\
\hline Ta ppm & 0.83 & 0.88 & 1.17 & 1.16 & 1.14 \\
\hline U ppm & 1.38 & 1.48 & 2.33 & 2.29 & 2.25 \\
\hline $\mathrm{Pb}$ ppm & 12.21 & 12.82 & 13.92 & 14.39 & 14.36 \\
\hline Rb ppm & 38.6 & 40.8 & 65.4 & 64.6 & 64.1 \\
\hline Cs ppm & 1.11 & 1.24 & 1.92 & 1.93 & 1.94 \\
\hline Sr ppm & 337 & 337 & 327 & 337 & 323 \\
\hline Sc ppm & 35.3 & 35.0 & 26.7 & 26.1 & 26.0 \\
\hline Zr ppm & 186 & 197 & 268 & 266 & 262 \\
\hline
\end{tabular}




\begin{tabular}{|c|c|c|c|c|c|}
\hline Sample ID & MAC-17-08 & MAC-17-09 & MAC-17-10 & MAC-17-11 & MAC-17-12 \\
\hline Dataset & Carley, 2017 & Carley, 2017 & Carley, 2017 & Carley, 2017 & Carley, 2017 \\
\hline Unit & Fiddler's Hell & Fiddler's Hell & Fiddler's Hell & Fiddler's Hell & Fiddler's Hell \\
\hline $\begin{array}{l}\text { Icelandite } \\
\text { Group }\end{array}$ & $\begin{array}{c}\text { Group } 1 \text { high } \\
\text { TiO2 }\end{array}$ & $\begin{array}{c}\text { Group } 1 \text { high } \\
\text { TiO2 }\end{array}$ & $\begin{array}{c}\text { Group } 1 \text { high } \\
\text { TiO2 }\end{array}$ & $\begin{array}{l}\text { Group } 1 \text { high } \\
\text { TiO2 }\end{array}$ & $\begin{array}{l}\text { Group } 1 \text { high } \\
\quad \mathrm{TiO} 2\end{array}$ \\
\hline Quad & Kamela SE & Huron & Drumhill Ridge & Drumhill Ridge & Drumhill Ridge \\
\hline Easting $(m)$ & 396454.40 & 402192.78 & 404359.81 & 405109.56 & 404285.70 \\
\hline Northing $(m)$ & 5021717.22 & 5031704.36 & 5030322.71 & 5031080.20 & 5038708.48 \\
\hline \multicolumn{6}{|c|}{ XRF Normalized Wt. \% } \\
\hline SiO2 & 60.31 & 60.01 & 59.82 & 60.59 & 59.71 \\
\hline TiO2 & 1.98 & 1.98 & 1.98 & 1.99 & 1.95 \\
\hline Al2O3 & 13.35 & 13.36 & 13.37 & 13.41 & 13.13 \\
\hline FeO* & 10.25 & 10.28 & 11.10 & 9.71 & 11.08 \\
\hline MnO & 0.21 & 0.23 & 0.23 & 0.21 & 0.21 \\
\hline MgO & 1.67 & 1.73 & 1.58 & 1.72 & 1.71 \\
\hline $\mathrm{CaO}$ & 5.20 & 5.41 & 5.20 & 5.33 & 5.31 \\
\hline $\mathrm{Na2O}$ & 3.50 & 3.41 & 3.65 & 3.49 & 3.74 \\
\hline K2O & 2.73 & 2.80 & 2.27 & 2.75 & 2.37 \\
\hline P2O5 & 0.794 & 0.798 & 0.785 & 0.805 & 0.786 \\
\hline \multicolumn{6}{|c|}{ XRF Trace (ppm) } \\
\hline $\mathrm{Ni}$ & 3 & 6 & 3 & 3 & 2 \\
\hline $\mathrm{Cr}$ & 0 & 1 & 0 & 0 & 0 \\
\hline Sc & 27 & 26 & 26 & 27 & 27 \\
\hline $\mathbf{v}$ & 49 & 49 & 55 & 52 & 48 \\
\hline $\mathrm{Ba}$ & 1104 & 1127 & 1280 & 1415 & 1005 \\
\hline $\mathbf{R b}$ & 65 & 65 & 63 & 66 & 61 \\
\hline $\mathrm{Sr}$ & 320 & 323 & 332 & 339 & 320 \\
\hline $\mathrm{Zr}$ & 263 & 263 & 260 & 267 & 262 \\
\hline$Y$ & 57 & 61 & 58 & 63 & 59 \\
\hline Nb & 17.4 & 18.2 & 18.1 & 18.2 & 17.7 \\
\hline Ga & 24 & 22 & 22 & 23 & 23 \\
\hline $\mathrm{Cu}$ & 6 & 9 & 6 & 6 & 7 \\
\hline $\mathrm{Zn}$ & 173 & 172 & 174 & 170 & 165 \\
\hline $\mathrm{Pb}$ & 35 & 16 & 15 & 16 & 15 \\
\hline La & 39 & 38 & 38 & 44 & 42 \\
\hline $\mathrm{Ce}$ & 84 & 86 & 82 & 87 & 82 \\
\hline Th & 10 & 8 & 9 & 9 & 8 \\
\hline Nd & 48 & 47 & 47 & 48 & 46 \\
\hline U & 4 & 3 & 2 & 3 & 4 \\
\hline
\end{tabular}




\begin{tabular}{|c|c|c|c|c|c|}
\hline Sample ID & MAC-17-08 & MAC-17-09 & MAC-17-10 & MAC-17-11 & MAC-17-12 \\
\hline Easting $(m)$ & 396454.40 & 402192.78 & 404359.81 & 405109.56 & 404285.70 \\
\hline Northing $(m)$ & 5021717.22 & 5031704.36 & 5030322.71 & 5031080.20 & 5038708.48 \\
\hline Unit & Fiddler's Hell & Fiddler's Hell & Fiddler's Hell & Fiddler's Hell & Fiddler's Hell \\
\hline \multicolumn{6}{|c|}{ ICP-MS Trace (ppm) } \\
\hline La ppm & 39.61 & 41.11 & 39.39 & 43.19 & 39.58 \\
\hline Ce ppm & 80.82 & 83.08 & 78.93 & 83.95 & 82.04 \\
\hline Pr ppm & 10.78 & 11.13 & 10.75 & 11.44 & 10.82 \\
\hline Nd ppm & 46.17 & 47.47 & 45.97 & 48.66 & 45.78 \\
\hline Sm ppm & 11.16 & 11.36 & 11.10 & 11.58 & 10.94 \\
\hline Eu ppm & 3.17 & 3.22 & 3.22 & 3.32 & 3.16 \\
\hline Gd ppm & 11.34 & 11.65 & 11.48 & 11.88 & 11.27 \\
\hline Tb ppm & 1.87 & 1.93 & 1.89 & 1.94 & 1.83 \\
\hline Dy ppm & 11.36 & 11.66 & 11.60 & 11.74 & 11.13 \\
\hline Ho ppm & 2.31 & 2.39 & 2.32 & 2.45 & 2.29 \\
\hline Er ppm & 6.17 & 6.38 & 6.17 & 6.57 & 6.20 \\
\hline Tm ppm & 0.87 & 0.89 & 0.87 & 0.91 & 0.87 \\
\hline Yb ppm & 5.24 & 5.50 & 5.45 & 5.58 & 5.31 \\
\hline Lu ppm & 0.83 & 0.88 & 0.84 & 0.87 & 0.85 \\
\hline Ba ppm & 1114 & 1120 & 1244 & 1404 & 990 \\
\hline Th ppm & 8.16 & 8.14 & 7.90 & 8.24 & 8.12 \\
\hline Nb ppm & 17.67 & 17.52 & 17.23 & 17.82 & 17.54 \\
\hline Y ppm & 58.54 & 60.95 & 57.75 & 63.23 & 59.98 \\
\hline Hf ppm & 7.01 & 6.99 & 6.80 & 7.13 & 7.04 \\
\hline Ta ppm & 1.17 & 1.17 & 1.13 & 1.18 & 1.17 \\
\hline U ppm & 2.31 & 2.31 & 2.23 & 2.33 & 2.30 \\
\hline $\mathrm{Pb}$ ppm & 36.26 & 15.57 & 13.79 & 14.77 & 15.53 \\
\hline Rb ppm & 65.4 & 65.5 & 62.4 & 65.4 & 62.1 \\
\hline Cs ppm & 1.89 & 1.87 & 1.87 & 1.92 & 1.74 \\
\hline Sr ppm & 324 & 322 & 328 & 339 & 324 \\
\hline Sc ppm & 27.3 & 27.1 & 26.9 & 27.3 & 27.1 \\
\hline Zr ppm & 266 & 263 & 257 & 269 & 263 \\
\hline
\end{tabular}




\begin{tabular}{|c|c|c|c|c|c|}
\hline Sample ID & MAC-17-13 & MAC-17-14 & MAC-17-15 & MAC-17-16 & MAC-17-18 \\
\hline Dataset & Carley, 2017 & Carley, 2017 & Carley, 2017 & Carley, 2017 & Carley, 2017 \\
\hline Unit & Fiddler's Hell & Fiddler's Hell & Fiddler's Hell & Fiddler's Hell & Fiddler's Hell \\
\hline $\begin{array}{l}\text { Icelandite } \\
\text { Group }\end{array}$ & $\begin{array}{l}\text { Group } 1 \text { high } \\
\text { TiO2 }\end{array}$ & $\begin{array}{c}\text { Group } 1 \text { high } \\
\text { TiO2 }\end{array}$ & Transition & $\begin{array}{c}\text { Group } 1 \text { high } \\
\mathrm{TiO} 2\end{array}$ & $\begin{array}{c}\text { Group } 1 \text { high } \\
\text { TiO2 }\end{array}$ \\
\hline Quad & Drumhill Ridge & Drumhill Ridge & La Grande SE & Glass Hill & Summerville \\
\hline Easting $(m)$ & 403972.31 & 405079.563 & 412615.46 & 415699.62 & 412329.51 \\
\hline Northing $(m)$ & 5039089.03 & 5037800.146 & 5023348.85 & 5003692.37 & 5038786.97 \\
\hline \multicolumn{6}{|c|}{ XRF Normalized Wt. \% } \\
\hline $\mathrm{SiO2}$ & 59.57 & 61.02 & 54.22 & 59.96 & 59.51 \\
\hline TiO2 & 1.96 & 2.01 & 2.14 & 1.95 & 1.97 \\
\hline Al2O3 & 13.21 & 13.56 & 13.65 & 13.19 & 13.31 \\
\hline FeO* & 11.17 & 8.84 & 13.19 & 11.25 & 11.02 \\
\hline MnO & 0.22 & 0.22 & 0.23 & 0.21 & 0.22 \\
\hline MgO & 1.75 & 1.74 & 3.83 & 1.55 & 1.74 \\
\hline $\mathrm{CaO}$ & 5.34 & 5.43 & 7.82 & 4.96 & 5.34 \\
\hline $\mathrm{Na2O}$ & 3.60 & 3.45 & 3.19 & 3.80 & 3.57 \\
\hline K2O & 2.40 & 2.91 & 1.34 & 2.35 & 2.54 \\
\hline P2O5 & 0.783 & 0.82 & 0.38 & 0.788 & 0.793 \\
\hline \multicolumn{6}{|c|}{ XRF Trace (ppm) } \\
\hline $\mathrm{Ni}$ & 3 & 3 & 12 & 4 & 3 \\
\hline $\mathrm{Cr}$ & 0 & 0 & 3 & 0 & 0 \\
\hline Sc & 27 & 27 & 37 & 26 & 26 \\
\hline $\mathbf{v}$ & 54 & 53 & 397 & 52 & 51 \\
\hline $\mathrm{Ba}$ & 989 & 1297 & 606 & 937 & 942 \\
\hline $\mathbf{R b}$ & 64 & 69 & 35 & 69 & 62 \\
\hline $\mathrm{Sr}$ & 319 & 343 & 347 & 313 & 316 \\
\hline $\mathrm{Zr}$ & 262 & 267 & 169 & 261 & 263 \\
\hline$Y$ & 60 & 61 & 39 & 58 & 60 \\
\hline Nb & 18.3 & 18.0 & 11.1 & 18.0 & 17.6 \\
\hline Ga & 22 & 24 & 22 & 22 & 23 \\
\hline $\mathrm{Cu}$ & 6 & 8 & 30 & 8 & 7 \\
\hline $\mathrm{Zn}$ & 157 & 171 & 143 & 156 & 166 \\
\hline $\mathrm{Pb}$ & 26 & 145 & 10 & 14 & 17 \\
\hline La & 42 & 38 & 24 & 40 & 39 \\
\hline $\mathrm{Ce}$ & 81 & 81 & 52 & 80 & 83 \\
\hline Th & 9 & 9 & 6 & 8 & 8 \\
\hline Nd & 46 & 46 & 27 & 45 & 46 \\
\hline u & 3 & 3 & 2 & 3 & 2 \\
\hline
\end{tabular}




\begin{tabular}{cccccc}
\hline \hline Sample ID & MAC-17-13 & MAC-17-14 & MAC-17-15 & MAC-17-16 & MAC-17-18 \\
Easting (m) & 403972.31 & 405079.563 & 412615.46 & 415699.62 & 412329.51 \\
Northing (m) & 5039089.03 & 5037800.146 & 5023348.85 & 5003692.37 & 5038786.97 \\
Unit & Fiddler's Hell & Fiddler's Hell & Fiddler's Hell & Fiddler's Hell & Fiddler's Hell \\
\hline ICP-MS Trace (ppm) & & & & & \\
La ppm & 42.21 & 40.81 & 23.35 & 38.85 & 41.13 \\
Ce ppm & 82.86 & 84.95 & 48.77 & 78.81 & 84.29 \\
Pr ppm & 11.21 & 11.00 & 6.57 & 10.73 & 11.07 \\
Nd ppm & 47.26 & 46.89 & 28.45 & 46.07 & 47.02 \\
Sm ppm & 11.25 & 11.09 & 6.96 & 11.13 & 11.49 \\
Eu ppm & 3.22 & 3.25 & 2.20 & 3.22 & 3.25 \\
Gd ppm & 11.55 & 11.53 & 7.32 & 11.50 & 11.55 \\
Tb ppm & 1.88 & 1.90 & 1.22 & 1.88 & 1.89 \\
Dy ppm & 11.60 & 11.50 & 7.64 & 11.42 & 11.49 \\
Ho ppm & 2.35 & 2.34 & 1.55 & 2.30 & 2.38 \\
Er ppm & 6.31 & 6.37 & 4.28 & 6.18 & 6.39 \\
Tm ppm & 0.88 & 0.89 & 0.61 & 0.87 & 0.89 \\
Yb ppm & 5.33 & 5.50 & 3.76 & 5.29 & 5.48 \\
Lu ppm & 0.85 & 0.85 & 0.58 & 0.82 & 0.86 \\
Ba ppm & 970 & 1299 & 598 & 935 & 931 \\
Th ppm & 8.12 & 8.36 & 3.99 & 8.11 & 8.18 \\
Nb ppm & 17.54 & 17.96 & 11.72 & 17.60 & 17.78 \\
Y ppm & 60.40 & 60.94 & 39.69 & 58.44 & 60.58 \\
Hf ppm & 6.97 & 7.24 & 4.64 & 7.01 & 7.08 \\
Ta ppm & 1.15 & 1.19 & 0.75 & 1.16 & 1.18 \\
U ppm & 2.31 & 2.41 & 1.14 & 2.29 & 2.41 \\
Pb ppm & 25.21 & 138.59 & 11.08 & 14.68 & 16.09 \\
Rb ppm & 64.0 & 69.2 & 34.49 & 68.2 & 61.9 \\
Cs ppm & 1.89 & 1.98 & 0.93 & 1.84 & 1.82 \\
Sr ppm & 321 & 344 & 355 & 317 & 319 \\
Sc ppm & 26.6 & 27.5 & 37.86 & 27.0 & 26.9 \\
Zr ppm & 264 & 271 & 171 & 263 & 268 \\
\hline \hline & & & & & \\
\hline
\end{tabular}




\begin{tabular}{|c|c|c|c|c|c|}
\hline Sample ID & MAC-17-22a & MAC-17-25 & MAC-17-26 & MAC-17-29 & MAC-17-32 \\
\hline Dataset & Carley, 2017 & Carley, 2017 & Carley, 2017 & Carley, 2017 & Carley, 2017 \\
\hline Unit & Fiddler's Hell & Fiddler's Hell & Fiddler's Hell & Fiddler's Hell & Hunter Creek \\
\hline $\begin{array}{l}\text { Icelandite } \\
\text { Group }\end{array}$ & Transition & Transition & Transition & $\begin{array}{c}\text { Group } 1 \text { high } \\
\text { TiO2 }\end{array}$ & $\begin{array}{c}\text { Group } 1 \text { low } \\
\text { TiO2 }\end{array}$ \\
\hline Quad & Summerville & $\begin{array}{l}\text { Medical } \\
\text { Springs }\end{array}$ & $\begin{array}{l}\text { Mclntyre } \\
\text { Creek }\end{array}$ & Meacham Lake & Namorf \\
\hline Easting $(m)$ & 414302.54 & 445533.44 & 385608.08 & 389606.53 & 441257.00 \\
\hline Northing $(m)$ & 5035266.52 & 4994587.50 & 5019791.54 & 5029335.61 & 4847697.51 \\
\hline \multicolumn{6}{|c|}{ XRF Normalized Wt. \% } \\
\hline SiO2 & 55.87 & 55.72 & 56.48 & 60.00 & 62.66 \\
\hline TiO2 & 2.38 & 2.26 & 2.23 & 1.96 & 1.22 \\
\hline Al203 & 13.32 & 13.70 & 13.76 & 13.21 & 13.54 \\
\hline FeO* & 13.35 & 12.44 & 12.02 & 10.63 & 9.84 \\
\hline Mno & 0.22 & 0.21 & 0.18 & 0.27 & 0.25 \\
\hline MgO & 2.81 & 3.15 & 2.86 & 1.74 & 0.75 \\
\hline $\mathrm{CaO}$ & 6.15 & 6.83 & 6.71 & 5.35 & 4.60 \\
\hline $\mathrm{Na2O}$ & 3.52 & 3.51 & 3.51 & 3.50 & 3.56 \\
\hline K2O & 1.77 & 1.75 & 1.80 & 2.55 & 3.31 \\
\hline P2O5 & 0.61 & 0.44 & 0.447 & 0.799 & 0.274 \\
\hline \multicolumn{6}{|c|}{ XRF Trace (ppm) } \\
\hline $\mathbf{N i}$ & 5 & 11 & 9 & 1 & 2 \\
\hline $\mathrm{Cr}$ & 0 & 0 & 3 & 0 & 3 \\
\hline Sc & 32 & 31 & 32 & 26 & 29 \\
\hline $\mathbf{v}$ & 235 & 323 & 318 & 50 & 22 \\
\hline $\mathrm{Ba}$ & 724 & 729 & 750 & 978 & 1138 \\
\hline $\mathbf{R b}$ & 46 & 46 & 51 & 66 & 82 \\
\hline $\mathrm{Sr}$ & 322 & 320 & 326 & 327 & 311 \\
\hline $\mathrm{Zr}$ & 216 & 203 & 204 & 263 & 296 \\
\hline $\mathbf{Y}$ & 47 & 42 & 42 & 59 & 57 \\
\hline Nb & 14.9 & 13.4 & 13.8 & 18.5 & 20.8 \\
\hline Ga & 22 & 21 & 21 & 23 & 22 \\
\hline $\mathrm{Cu}$ & 14 & 22 & 20 & 6 & 11 \\
\hline $\mathrm{Zn}$ & 161 & 145 & 152 & 147 & 165 \\
\hline $\mathrm{Pb}$ & 17 & 13 & 17 & 11 & 15 \\
\hline La & 29 & 27 & 29 & 37 & 37 \\
\hline $\mathrm{Ce}$ & 66 & 55 & 61 & 85 & 86 \\
\hline Th & 7 & 6 & 7 & 8 & 9 \\
\hline Nd & 35 & 29 & 31 & 46 & 45 \\
\hline U & 2 & 2 & 3 & 3 & 4 \\
\hline
\end{tabular}




\begin{tabular}{|c|c|c|c|c|c|}
\hline Sample ID & MAC-17-22a & MAC-17-25 & MAC-17-26 & MAC-17-29 & MAC-17-32 \\
\hline Easting $(m)$ & 414302.54 & 445533.44 & 385608.08 & 389606.53 & 441257.00 \\
\hline Northing (m) & 5035266.52 & 4994587.50 & 5019791.54 & 5029335.61 & 4847697.51 \\
\hline Unit & Fiddler's Hell & Fiddler's Hell & Fiddler's Hell & Fiddler's Hell & Hunter Creek \\
\hline \multicolumn{6}{|c|}{ ICP-MS Trace (ppm) } \\
\hline La ppm & 30.26 & 27.50 & 28.23 & 40.02 & 39.41 \\
\hline Ce ppm & 64.15 & 57.95 & 57.16 & 83.06 & 83.09 \\
\hline Pr ppm & 8.46 & 7.57 & 7.80 & 10.80 & 10.89 \\
\hline Nd ppm & 36.49 & 32.50 & 32.99 & 45.92 & 46.09 \\
\hline Sm ppm & 8.93 & 7.78 & 7.90 & 10.98 & 11.17 \\
\hline Eu ppm & 2.72 & 2.35 & 2.34 & 3.19 & 3.53 \\
\hline Gd ppm & 9.13 & 8.05 & 8.25 & 11.33 & 11.05 \\
\hline Tb ppm & 1.52 & 1.33 & 1.36 & 1.85 & 1.85 \\
\hline Dy ppm & 9.32 & 8.16 & 8.17 & 11.37 & 11.27 \\
\hline Ho ppm & 1.87 & 1.67 & 1.66 & 2.35 & 2.32 \\
\hline Er ppm & 5.05 & 4.49 & 4.56 & 6.26 & 6.32 \\
\hline Tm ppm & 0.72 & 0.63 & 0.64 & 0.87 & 0.92 \\
\hline Yb ppm & 4.43 & 3.93 & 3.87 & 5.41 & 5.79 \\
\hline Lu ppm & 0.72 & 0.61 & 0.60 & 0.85 & 0.97 \\
\hline Ba ppm & 717 & 721 & 740 & 985 & 1155 \\
\hline Th ppm & 5.99 & 5.57 & 5.54 & 8.26 & 8.43 \\
\hline Nb ppm & 14.87 & 13.39 & 13.44 & 17.74 & 20.61 \\
\hline Y ppm & 46.95 & 41.63 & 42.25 & 60.60 & 58.18 \\
\hline Hf ppm & 5.85 & 5.45 & 5.47 & 7.13 & 8.01 \\
\hline Ta ppm & 0.97 & 0.88 & 0.88 & 1.17 & 1.26 \\
\hline U ppm & 1.70 & 1.65 & 1.63 & 2.34 & 2.57 \\
\hline $\mathrm{Pb}$ ppm & 16.27 & 12.02 & 15.87 & 12.27 & 12.94 \\
\hline Rb ppm & 46.3 & 45.3 & 49.3 & 66.3 & 83.8 \\
\hline Cs ppm & 1.01 & 1.07 & 1.58 & 1.94 & 2.25 \\
\hline Sr ppm & 326 & 321 & 325 & 331 & 315 \\
\hline Sc ppm & 33.3 & 32.2 & 31.8 & 27.1 & 31.7 \\
\hline Zr ppm & 220 & 204 & 204 & 266 & 301 \\
\hline
\end{tabular}




\begin{tabular}{|c|c|c|c|c|c|}
\hline Sample ID & MAC-17-33 & MAC-17-34b & MAC-17-37 & U34 & U38 \\
\hline Dataset & Carley, 2017 & Carley, 2017 & Carley, 2017 & Streck, 2013 & Streck, 2013 \\
\hline Unit & Hunter Creek & Hunter Creek & Fiddler's Hell & $\mathrm{N} / \mathrm{S}$ of Ironside & $\mathrm{N} / \mathrm{S}$ of Ironside \\
\hline $\begin{array}{l}\text { Icelandite } \\
\text { Group }\end{array}$ & Low SIO2 & Transition & Transition & $\begin{array}{c}\text { Group } 2 \text { low } \\
\text { TiO2 }\end{array}$ & $\begin{array}{c}\text { Group } 2 \text { low } \\
\text { TiO2 }\end{array}$ \\
\hline Quad & Westfall & Jonesboro & Tucker Flat & Eldorado Pass & $\begin{array}{l}\text { Rastus } \\
\text { Mountain }\end{array}$ \\
\hline Easting $(m)$ & 449720.11 & 423693.99 & 414556.41 & 419965.06 & 405411.75 \\
\hline Northing $(m)$ & 4870183.00 & 4850860.25 & 4995044.26 & 4901556.78 & 4910815.25 \\
\hline \multicolumn{6}{|c|}{ XRF Normalized Wt. \% } \\
\hline SiO2 & 57.15 & 56.13 & 54.55 & 61.45 & 60.86 \\
\hline TiO2 & 2.39 & 2.41 & 2.34 & 1.29 & 1.38 \\
\hline Al2O3 & 13.41 & 13.71 & 14.08 & 14.85 & 14.83 \\
\hline FeO* & 11.38 & 11.95 & 11.43 & 9.97 & 9.33 \\
\hline MnO & 0.53 & 0.20 & 0.19 & 0.14 & 0.20 \\
\hline MgO & 2.43 & 3.12 & 4.03 & 1.06 & 1.45 \\
\hline $\mathrm{CaO}$ & 6.47 & 7.00 & 8.18 & 4.52 & 5.08 \\
\hline $\mathrm{Na2O}$ & 3.07 & 3.04 & 3.05 & 4.07 & 3.62 \\
\hline K2O & 2.40 & 1.99 & 1.74 & 2.11 & 2.70 \\
\hline P2O5 & 0.764 & 0.453 & 0.40 & 0.527 & 0.543 \\
\hline \multicolumn{6}{|c|}{ XRF Trace (ppm) } \\
\hline $\mathrm{Ni}$ & 2 & 6 & 25 & 2 & 3 \\
\hline $\mathrm{Cr}$ & 0 & 6 & 36 & 1 & 1 \\
\hline Sc & 30 & 32 & 31 & 23 & 21 \\
\hline $\mathbf{v}$ & 167 & 360 & 313 & 47 & 115 \\
\hline $\mathrm{Ba}$ & 979 & 946 & 569 & 890 & 1038 \\
\hline $\mathbf{R b}$ & 63 & 50 & 41 & 48 & 60 \\
\hline $\mathrm{Sr}$ & 342 & 344 & 349 & 300 & 305 \\
\hline $\mathrm{Zr}$ & 232 & 219 & 191 & 207 & 202 \\
\hline$Y$ & 49 & 42 & 34 & 44 & 49 \\
\hline Nb & 16.9 & 14.7 & 12.4 & 12.0 & 10.1 \\
\hline Ga & 22 & 22 & 20 & 23 & 23 \\
\hline $\mathrm{Cu}$ & 7 & 12 & 66 & 6 & 6 \\
\hline $\mathrm{Zn}$ & 153 & 141 & 125 & 177 & 207 \\
\hline $\mathrm{Pb}$ & 11 & 9 & 9 & 8 & 9 \\
\hline La & 33 & 31 & 21 & 21 & 22 \\
\hline $\mathrm{Ce}$ & 78 & 62 & 49 & 49 & 56 \\
\hline Th & 7 & 7 & 6 & 3 & 5 \\
\hline Nd & 40 & 32 & 30 & 32 & 31 \\
\hline U & 2 & 3 & 3 & 2 & 4 \\
\hline
\end{tabular}




\begin{tabular}{cccccc}
\hline \hline Sample ID & MAC-17-33 & MAC-17-34b & MAC-17-37 & U34 & U38 \\
Easting (m) & 449720.11 & 423693.99 & 414556.41 & 419965.06 & 405411.75 \\
Northing (m) & 4870183.00 & 4850860.25 & 4995044.26 & 4901556.78 & 4910815.25 \\
Unit & Hunter Creek & Hunter Creek & Fiddler's Hell & N/S of Ironside & N/S of Ironside \\
\hline ICP-MS Trace (ppm) & & & & & \\
La ppm & 34.67 & 30.34 & 22.74 & 22.23 & 23.42 \\
Ce ppm & 73.43 & 62.84 & 49.18 & 46.76 & 49.81 \\
Pr ppm & 9.62 & 8.11 & 6.57 & 7.07 & 6.79 \\
Nd ppm & 40.93 & 34.06 & 28.63 & 30.90 & 28.95 \\
Sm ppm & 9.77 & 8.07 & 7.20 & 7.60 & 7.15 \\
Eu ppm & 2.95 & 2.37 & 2.12 & 2.18 & 1.69 \\
Gd ppm & 9.87 & 8.27 & 7.27 & 7.79 & 7.73 \\
Tb ppm & 1.59 & 1.38 & 1.20 & 1.30 & 1.34 \\
Dy ppm & 9.66 & 8.35 & 7.11 & 8.07 & 8.47 \\
Ho ppm & 1.96 & 1.71 & 1.42 & 1.67 & 1.80 \\
Er ppm & 5.16 & 4.66 & 3.75 & 4.51 & 5.04 \\
Tm ppm & 0.72 & 0.65 & 0.53 & 0.66 & 0.75 \\
Yb ppm & 4.44 & 4.05 & 3.19 & 4.16 & 4.74 \\
Lu ppm & 0.71 & 0.64 & 0.49 & 0.65 & 0.76 \\
Ba ppm & 977 & 942 & 559 & 879 & 1027 \\
Th ppm & 6.84 & 6.31 & 4.67 & 4.14 & 5.07 \\
Nb ppm & 16.49 & 14.96 & 12.41 & 11.28 & 9.33 \\
Y ppm & 49.28 & 43.21 & 35.38 & 43.18 & 48.75 \\
Hf ppm & 6.15 & 5.84 & 5.15 & 5.57 & 5.51 \\
Ta ppm & 1.07 & 0.99 & 0.84 & 0.69 & 0.61 \\
U ppm & 2.01 & 1.82 & 1.47 & 2.02 & 2.54 \\
Pb ppm & 10.88 & 9.88 & 9.02 & 8.21 & 8.48 \\
Rb ppm & 62.3 & 49.5 & 40.63 & 46.8 & 57.5 \\
Cs ppm & 1.81 & 1.50 & 1.38 & 2.50 & 2.30 \\
Sr ppm & 344 & 348 & 353 & 305 & 311 \\
Sc ppm & 31.5 & 32.3 & 31.41 & 26.7 & 24.3 \\
Zr ppm & 235 & 222 & 193 & 211 & 207 \\
\hline \hline
\end{tabular}




\begin{tabular}{|c|c|c|c|c|c|}
\hline Sample ID & MS-14-17 & MS-15-19C & MS-15-23A & MS-15-23B & MS-15-23C \\
\hline Dataset & Streck, 2014 & Streck, 2014 & Streck, 2014 & Streck, 2014 & Streck, 2014 \\
\hline Unit & $\begin{array}{l}\text { DIT dacite } \\
\text { flow? }\end{array}$ & $\begin{array}{c}\text { thin Buchanan } \\
\text { welded fall out } \\
\text { tuff }\end{array}$ & $\begin{array}{l}\text { unit } 1 \text { mafic } \\
\text { pyroclast }\end{array}$ & $\begin{array}{c}\text { unit } 2 \text { mafic } \\
\text { pyroclast }\end{array}$ & $\begin{array}{c}\text { unit } 3 \text { mafic } \\
\text { pyroclastic, } \\
\text { GR2 }\end{array}$ \\
\hline $\begin{array}{l}\text { Icelandite } \\
\text { Group }\end{array}$ & $\begin{array}{c}\text { Group } 2 \text { high } \\
\text { TiO2 }\end{array}$ & $\begin{array}{c}\text { Group } 2 \text { high } \\
\text { TiO2 }\end{array}$ & $\begin{array}{l}\text { Group } 2 \text { high } \\
\text { TiO2 }\end{array}$ & $\begin{array}{l}\text { Group } 2 \text { high } \\
\text { TiO2 }\end{array}$ & Low SIO2 \\
\hline Quad & $\begin{array}{l}\text { Diamond } \\
\text { Swamp }\end{array}$ & $\begin{array}{l}\text { Jump-Off Joe } \\
\text { Mountain }\end{array}$ & $\begin{array}{l}\text { Jump-Off Joe } \\
\text { Mountain }\end{array}$ & $\begin{array}{l}\text { Jump-Off Joe } \\
\text { Mountain }\end{array}$ & $\begin{array}{l}\text { Jump-Off Joe } \\
\text { Mountain }\end{array}$ \\
\hline Easting $(m)$ & 352425.23 & 371204.76 & 353465.80 & 353465.80 & 353466.00 \\
\hline Northing $(m)$ & 4874835.48 & 4835599.21 & 4874443.83 & 4874443.83 & 4874453.05 \\
\hline \multicolumn{6}{|c|}{ XRF Normalized Wt. \% } \\
\hline $\mathrm{SiO2}$ & 59.58 & 58.98 & 59.59 & 59.78 & 57.91 \\
\hline TiO2 & 1.93 & 1.96 & 1.86 & 1.87 & 1.84 \\
\hline $\mathrm{Al} 2 \mathrm{O} 3$ & 15.25 & 14.96 & 15.30 & 15.00 & 16.09 \\
\hline FeO* & 9.07 & 8.89 & 8.92 & 9.10 & 9.36 \\
\hline Mno & 0.17 & 0.21 & 0.18 & 0.17 & 0.19 \\
\hline MgO & 1.84 & 2.52 & 1.79 & 1.93 & 1.51 \\
\hline $\mathrm{CaO}$ & 5.10 & 5.64 & 5.38 & 5.19 & 5.77 \\
\hline $\mathrm{Na2O}$ & 4.27 & 3.69 & 3.87 & 4.25 & 4.32 \\
\hline K2O & 1.91 & 2.23 & 1.99 & 1.81 & 1.40 \\
\hline P2O5 & 0.868 & 0.925 & 1.118 & 0.879 & 1.623 \\
\hline \multicolumn{6}{|c|}{ XRF Trace (ppm) } \\
\hline $\mathrm{Ni}$ & 5 & 4 & 5 & 7 & 8 \\
\hline $\mathrm{Cr}$ & 12 & 0 & 1 & 0 & 0 \\
\hline Sc & 24 & 24 & 23 & 24 & 24 \\
\hline $\mathbf{v}$ & 136 & 142 & 114 & 120 & 66 \\
\hline $\mathrm{Ba}$ & 998 & 1065 & 1005 & 1072 & 1106 \\
\hline $\mathbf{R b}$ & 37 & 38 & 45 & 39 & 12 \\
\hline $\mathrm{Sr}$ & 409 & 390 & 407 & 416 & 411 \\
\hline $\mathrm{Zr}$ & 197 & 191 & 196 & 192 & 208 \\
\hline$Y$ & 47 & 45 & 43 & 42 & 52 \\
\hline Nb & 14.4 & 13.2 & 13.4 & 13.5 & 15.2 \\
\hline $\mathrm{Ga}$ & 20 & 19 & 19 & 19 & 20 \\
\hline $\mathrm{Cu}$ & 12 & 6 & 8 & 7 & 10 \\
\hline $\mathrm{Zn}$ & 145 & 141 & 124 & 133 & 123 \\
\hline $\mathrm{Pb}$ & 9 & 8 & 6 & 8 & 7 \\
\hline La & 31 & 28 & 27 & 28 & 31 \\
\hline $\mathrm{Ce}$ & 59 & 56 & 61 & 59 & 67 \\
\hline Th & 4 & 5 & 4 & 3 & 4 \\
\hline Nd & 39 & 35 & 36 & 33 & 40 \\
\hline $\mathbf{U}$ & 1 & 1 & 4 & 3 & 3 \\
\hline
\end{tabular}




\begin{tabular}{|c|c|c|c|c|c|}
\hline Sample ID & MS-14-17 & MS-15-19C & MS-15-23A & MS-15-23B & MS-15-23C \\
\hline Easting $(m)$ & 352425.23 & 371204.76 & 353465.80 & 353465.80 & 353466.00 \\
\hline Northing (m) & 4874835.48 & 4835599.21 & 4874443.83 & 4874443.83 & 4874453.05 \\
\hline Unit & $\begin{array}{l}\text { DIT dacite } \\
\text { flow? }\end{array}$ & $\begin{array}{c}\text { thin Buchanan } \\
\text { welded fall- } \\
\text { out tuff }\end{array}$ & $\begin{array}{l}\text { unit } 1 \text { mafic } \\
\text { pyroclastic }\end{array}$ & $\begin{array}{l}\text { unit } 2 \text { mafic } \\
\text { pyroclastic }\end{array}$ & $\begin{array}{c}\text { unit } 3 \text { mafic } \\
\text { pyroclastic, } \\
\text { GR2 }\end{array}$ \\
\hline \multicolumn{6}{|c|}{ ICP-MS Trace (ppm) } \\
\hline La ppm & 29.62 & 28.63 & 28.83 & 27.82 & 34.40 \\
\hline Ce ppm & 60.43 & 62.07 & 63.08 & 61.22 & 65.75 \\
\hline Pr ppm & 8.88 & 8.44 & 8.58 & 8.41 & 9.77 \\
\hline $\mathrm{Nd} \mathrm{ppm}$ & 38.26 & 36.98 & 36.77 & 36.44 & 41.49 \\
\hline Sm ppm & 9.18 & 8.70 & 8.67 & 8.61 & 9.66 \\
\hline Eu ppm & 2.93 & 2.93 & 2.84 & 2.88 & 3.00 \\
\hline Gd ppm & 9.50 & 8.85 & 8.65 & 8.49 & 9.52 \\
\hline Tb ppm & 1.51 & 1.42 & 1.39 & 1.38 & 1.56 \\
\hline Dy ppm & 9.10 & 8.54 & 8.43 & 8.47 & 9.49 \\
\hline Ho ppm & 1.86 & 1.70 & 1.71 & 1.69 & 1.97 \\
\hline Er ppm & 5.04 & 4.63 & 4.62 & 4.53 & 5.30 \\
\hline Tm ppm & 0.72 & 0.67 & 0.65 & 0.63 & 0.75 \\
\hline Yb ppm & 4.52 & 4.12 & 4.07 & 3.87 & 4.72 \\
\hline Lu ppm & 0.70 & 0.65 & 0.65 & 0.62 & 0.76 \\
\hline Ba ppm & 1000 & 1067 & 1029 & 1094 & 1148 \\
\hline Th ppm & 3.88 & 3.63 & 4.04 & 3.80 & 4.16 \\
\hline Nb ppm & 13.28 & 13.59 & 13.88 & 13.60 & 14.88 \\
\hline Y ppm & 46.92 & 45.07 & 44.03 & 43.44 & 52.54 \\
\hline Hf ppm & 4.98 & 4.97 & 5.22 & 5.02 & 5.53 \\
\hline Ta ppm & 0.86 & 0.91 & 0.92 & 0.84 & 0.91 \\
\hline U ppm & 1.89 & 1.66 & 2.37 & 1.74 & 3.53 \\
\hline $\mathrm{Pb}$ ppm & 7.73 & 7.62 & 7.21 & 7.64 & 5.87 \\
\hline $\mathrm{Rb}$ ppm & 35.8 & 37.2 & 44.7 & 37.9 & 10.8 \\
\hline Cs ppm & 1.81 & 1.80 & 2.03 & 2.43 & 0.40 \\
\hline Sr ppm & 410 & 396 & 417 & 431 & 428 \\
\hline Sc ppm & 24.6 & 24.0 & 24.0 & 25.2 & 25.0 \\
\hline Zr ppm & 193 & 196 & 202 & 198 & 214 \\
\hline
\end{tabular}




\begin{tabular}{|c|c|c|c|c|c|}
\hline Sample ID & MS-15-31 & MS-12-34 & BW-15-31 & BW-15-35 & BW-14-37A \\
\hline Dataset & Streck, 2014 & Streck, 2016 & Webb, 2015 & Webb, 2015 & Webb, 2016 \\
\hline Unit & $\begin{array}{c}\text { BCT mafic } \\
\text { scoria }\end{array}$ & Hunter at Neal & GR2 & & $\begin{array}{l}\text { Alder Creek } \\
\text { Icelandite }\end{array}$ \\
\hline $\begin{array}{l}\text { Icelandite } \\
\text { Group }\end{array}$ & $\begin{array}{c}\text { Group } 2 \text { low } \\
\text { TiO2 }\end{array}$ & $\begin{array}{l}\text { Group } 1 \text { low } \\
\quad \mathrm{TiO} 2\end{array}$ & Low SIO2 & $\begin{array}{l}\text { Transition } \\
\text { group }\end{array}$ & $\begin{array}{c}\text { Group } 1 \text { low } \\
\text { TiO2 }\end{array}$ \\
\hline Quad & Westfall & Hope Butte & Namorf & Namorf & Alder Creek \\
\hline Easting (m) & 441001.68 & 463326.29 & 440006.9997 & 440602.35 & 433140.00 \\
\hline Northing (m) & 4871599.38 & 4874738.45 & 4826016.156 & 4846481.51 & 4826063.21 \\
\hline \multicolumn{6}{|c|}{ XRF Normalized Wt. \% } \\
\hline $\mathrm{SiO2}$ & 60.30 & 60.46 & 57.43 & 56.81 & 63.28 \\
\hline TiO2 & 1.50 & 1.56 & 2.30 & 2.36 & 1.23 \\
\hline Al2O3 & 14.79 & 12.87 & 13.75 & 14.54 & 13.31 \\
\hline $\mathrm{FeO} *$ & 10.02 & 11.76 & 10.87 & 11.21 & 9.92 \\
\hline Mno & 0.18 & 0.26 & 0.26 & 0.17 & 0.20 \\
\hline MgO & 1.52 & 1.32 & 2.86 & 2.73 & 0.82 \\
\hline $\mathrm{CaO}$ & 5.33 & 5.04 & 6.39 & 6.40 & 4.09 \\
\hline $\mathrm{Na2O}$ & 3.53 & 3.49 & 3.30 & 3.72 & 3.76 \\
\hline K2O & 2.20 & 2.65 & 2.28 & 1.68 & 3.03 \\
\hline P2O5 & 0.620 & 0.589 & 0.560 & 0.384 & 0.367 \\
\hline \multicolumn{6}{|c|}{ XRF Trace (ppm) } \\
\hline $\mathrm{Ni}$ & 5 & 4 & 8 & 3 & 2 \\
\hline $\mathrm{Cr}$ & 0 & 0 & 0 & 0 & 0 \\
\hline Sc & 29 & 26 & 30 & 32 & 23 \\
\hline $\mathbf{v}$ & 65 & 23 & 228 & 323 & 5 \\
\hline $\mathrm{Ba}$ & 834 & 1104 & 841 & 703 & 1198 \\
\hline $\mathbf{R b}$ & 46 & 82 & 60 & 38 & 81 \\
\hline $\mathrm{Sr}$ & 327 & 310 & 342 & 357 & 280 \\
\hline $\mathrm{Zr}$ & 176 & 293 & 243 & 219 & 357 \\
\hline$Y$ & 48 & 60 & 48 & 37 & 67 \\
\hline $\mathbf{N b}$ & 10.0 & 20.8 & 15.1 & 13.9 & 24.3 \\
\hline Ga & 19 & 22 & 22 & 22 & 23 \\
\hline $\mathrm{Cu}$ & 10 & 8 & 22 & 11 & 5 \\
\hline $\mathrm{Zn}$ & 190 & 165 & 137 & 132 & 156 \\
\hline $\mathrm{Pb}$ & 15 & 13 & 10 & 11 & 14 \\
\hline La & 24 & 44 & 28 & 25 & 45 \\
\hline $\mathrm{Ce}$ & 53 & 96 & 65 & 56 & 95 \\
\hline Th & 5 & 8 & 6 & 5 & 10 \\
\hline Nd & 33 & 52 & 38 & 31 & 50 \\
\hline $\mathbf{U}$ & 2 & 3 & 1 & 3 & 3 \\
\hline
\end{tabular}




\begin{tabular}{|c|c|c|c|c|c|}
\hline Sample ID & MS-15-31 & MS-12--34 & BW-15-31 & BW-15-35 & BW-14-37A \\
\hline Easting $(m)$ & 441001.68 & 463326.29 & 440006.9997 & 440602.35 & 433140.00 \\
\hline Northing $(m)$ & 4871599.38 & 4874738.45 & 4826016.156 & 4846481.51 & 4826063.21 \\
\hline Unit & $\begin{array}{c}\text { BCT mafic } \\
\text { scoria }\end{array}$ & Hunter at Neal & GR2 & & $\begin{array}{c}\text { Alder Creek } \\
\text { Icelandite }\end{array}$ \\
\hline \multicolumn{6}{|c|}{ ICP-MS Trace (ppm) } \\
\hline La ppm & 23.81 & 42.40 & 24.30 & 25.25 & 46.65 \\
\hline Ce ppm & 52.36 & 92.44 & 52.92 & 54.70 & 94.45 \\
\hline Pr ppm & 7.32 & 11.99 & 7.00 & 7.39 & 12.54 \\
\hline $\mathrm{Nd} \mathrm{ppm}$ & 31.54 & 50.12 & 30.23 & 31.88 & 51.72 \\
\hline Sm ppm & 8.09 & 11.61 & 7.58 & 7.82 & 12.06 \\
\hline Eu ppm & 2.28 & 3.49 & 2.36 & 2.41 & 3.38 \\
\hline Gd ppm & 8.39 & 11.39 & 7.69 & 7.91 & 12.26 \\
\hline Tb ppm & 1.46 & 1.87 & 1.28 & 1.30 & 2.03 \\
\hline Dy ppm & 9.18 & 11.50 & 7.68 & 7.78 & 12.43 \\
\hline Ho ppm & 1.90 & 2.37 & 1.56 & 1.54 & 2.60 \\
\hline Er ppm & 5.26 & 6.46 & 4.17 & 4.00 & 7.04 \\
\hline Tm ppm & 0.77 & 0.90 & 0.59 & 0.57 & 1.01 \\
\hline Yb ppm & 4.86 & 5.68 & 3.58 & 3.53 & 6.24 \\
\hline Lu ppm & 0.80 & 0.90 & 0.57 & 0.54 & 0.97 \\
\hline Ba ppm & 842 & 1091 & 691.00 & 700 & 1204 \\
\hline Th ppm & 4.39 & 8.35 & 4.80 & 5.02 & 9.76 \\
\hline Nb ppm & 10.36 & 20.11 & 13.00 & 13.36 & 22.77 \\
\hline Y ppm & 49.62 & 59.51 & 38.50 & 36.74 & 67.67 \\
\hline Hf ppm & 4.90 & 7.66 & 5.68 & 5.85 & 9.20 \\
\hline Ta ppm & 0.63 & 1.27 & 0.89 & 0.89 & 1.43 \\
\hline U ppm & 2.36 & 2.47 & 1.44 & 1.70 & 2.80 \\
\hline Pb ppm & 14.86 & 12.30 & 8.16 & 10.03 & 14.31 \\
\hline Rb ppm & 46.2 & 80.3 & 41.36 & 37.2 & 79.5 \\
\hline Cs ppm & 2.02 & 2.16 & 2.24 & 1.33 & 2.57 \\
\hline Sr ppm & 341 & 317 & 349.00 & 358 & 286 \\
\hline Sc ppm & 29.3 & 25.7 & 30.93 & 32.0 & 23.1 \\
\hline Zr ppm & 183 & 290 & 214.00 & 220 & 349 \\
\hline
\end{tabular}




\begin{tabular}{|c|c|c|c|c|c|}
\hline Sample ID & BW-14-37B & MC-15-16 & MC-45-16 & MC-69-16 & MC-94-16 \\
\hline Dataset & Webb, 2016 & Cruz, 2016 & Cruz, 2017 & Cruz, 2017 & Cruz, 2017 \\
\hline Unit & $\begin{array}{l}\text { Alder Creek } \\
\text { Icelandite }\end{array}$ & & $\begin{array}{l}\text { icelandite } \\
\text { (DIT4) }\end{array}$ & $\begin{array}{l}\text { icelandite } \\
\text { (DIT4) }\end{array}$ & Hunter Creek \\
\hline Icelandite & Group 1 low & Group 2 low & Group 2 low & Group 2 low & Group 2 low \\
\hline Group & $\mathrm{TiO} 2$ & $\mathrm{TiO} 2$ & TiO2 & TiO2 & TiO2 \\
\hline Quad & Alder Creek & Castle Rock & Castle Rock & Castle Rock & Eldorado Pass \\
\hline Easting $(m)$ & 433167.00 & 407222.62 & 406451.31 & 401283.06 & 418812.57 \\
\hline Northing (m) & 4826016.21 & 4873690.51 & 4879233.75 & 4880231.16 & 4900676.68 \\
\hline \multicolumn{6}{|c|}{ XRF Normalized Wt. \% } \\
\hline $\mathrm{SiO2}$ & 63.13 & 63.20 & 61.36 & 62.42 & 59.93 \\
\hline TiO2 & 1.19 & 1.08 & 1.28 & 1.46 & 1.49 \\
\hline Al203 & 13.15 & 15.13 & 15.10 & 14.64 & 14.57 \\
\hline $\mathrm{FeO}^{*}$ & 10.20 & 7.96 & 10.54 & 10.36 & 10.37 \\
\hline MnO & 0.21 & 0.13 & 0.18 & 0.16 & 0.19 \\
\hline MgO & 0.84 & 1.24 & 2.54 & 2.76 & 1.62 \\
\hline $\mathrm{CaO}$ & 3.99 & 4.35 & 5.16 & 4.61 & 5.12 \\
\hline $\mathrm{Na2O}$ & 4.05 & 3.85 & 2.12 & 1.49 & 4.05 \\
\hline K2O & 2.87 & 2.66 & 1.45 & 1.70 & 2.01 \\
\hline P2O5 & 0.362 & 0.402 & 0.269 & 0.405 & 0.653 \\
\hline \multicolumn{6}{|c|}{ XRF Trace (ppm) } \\
\hline $\mathrm{Ni}$ & 0 & 3 & 11 & 3 & 2 \\
\hline $\mathrm{Cr}$ & 0 & 1 & 10 & 0 & 0 \\
\hline Sc & 22 & 17 & 27 & 22 & 24 \\
\hline $\mathbf{v}$ & 5 & 77 & 182 & 143 & 80 \\
\hline $\mathrm{Ba}$ & 1189 & 1004 & 936 & 822 & 889 \\
\hline $\mathbf{R b}$ & 81 & 61 & 29 & 35 & 46 \\
\hline $\mathrm{Sr}$ & 270 & 297 & 242 & 230 & 310 \\
\hline $\mathrm{Zr}$ & 356 & 210 & 154 & 185 & 192 \\
\hline $\mathbf{Y}$ & 62 & 45 & 49 & 46 & 51 \\
\hline Nb & 24.2 & 9.8 & 7.4 & 9.9 & 11.0 \\
\hline Ga & 23 & 21 & 19 & 18 & 21 \\
\hline $\mathrm{Cu}$ & 4 & 5 & 15 & 7 & 6 \\
\hline $\mathrm{Zn}$ & 159 & 181 & 129 & 177 & 174 \\
\hline $\mathrm{Pb}$ & 14 & 12 & 7 & 10 & 8 \\
\hline La & 41 & 23 & 20 & 20 & 27 \\
\hline $\mathrm{Ce}$ & 93 & 54 & 36 & 44 & 52 \\
\hline Th & 10 & 5 & 4 & 4 & 4 \\
\hline Nd & 49 & 30 & 24 & 27 & 32 \\
\hline U & 4 & 3 & 2 & 1 & 3 \\
\hline
\end{tabular}




\begin{tabular}{|c|c|c|c|c|c|}
\hline Sample ID & BW-14-37B & MC-15-16 & MC-45-16 & MC-69-16 & MC-94-16 \\
\hline Easting (m) & 433167.00 & 407222.62 & 406451.31 & 401283.06 & 418812.57 \\
\hline Northing $(m)$ & 4826016.21 & 4873690.51 & 4879233.75 & 4880231.16 & 4900676.68 \\
\hline Unit & $\begin{array}{l}\text { Alder Creek } \\
\text { Icelandite }\end{array}$ & & $\begin{array}{c}\text { icelandite } \\
\text { (DIT4) }\end{array}$ & $\begin{array}{l}\text { icelandite } \\
\text { (DIT4) }\end{array}$ & Hunter Creek \\
\hline \multicolumn{6}{|c|}{ ICP-MS Trace (ppm) } \\
\hline La ppm & 46.34 & 25.10 & 20.06 & 21.97 & 24.46 \\
\hline Ce ppm & 96.52 & 51.67 & 38.26 & 44.48 & 53.02 \\
\hline Pr ppm & 12.38 & 7.00 & 5.63 & 6.34 & 7.55 \\
\hline $\mathrm{Nd} \mathrm{ppm}$ & 51.07 & 29.59 & 23.97 & 26.97 & 33.21 \\
\hline Sm ppm & 11.96 & 7.09 & 5.92 & 6.57 & 8.31 \\
\hline Eu ppm & 3.45 & 1.65 & 1.64 & 1.96 & 2.35 \\
\hline Gd ppm & 11.64 & 7.32 & 6.67 & 7.28 & 9.04 \\
\hline Tb ppm & 1.95 & 1.26 & 1.22 & 1.28 & 1.54 \\
\hline Dy ppm & 11.99 & 7.97 & 8.12 & 8.28 & 9.62 \\
\hline Ho ppm & 2.45 & 1.70 & 1.77 & 1.79 & 2.01 \\
\hline Er ppm & 6.56 & 4.89 & 5.11 & 5.13 & 5.48 \\
\hline Tm ppm & 0.97 & 0.70 & 0.76 & 0.75 & 0.81 \\
\hline Yb ppm & 5.99 & 4.49 & 4.83 & 4.83 & 5.01 \\
\hline Lu ppm & 0.97 & 0.71 & 0.80 & 0.80 & 0.80 \\
\hline Ba ppm & 1199 & 1010 & 950 & 832 & 889 \\
\hline Th ppm & 9.83 & 5.35 & 2.95 & 3.74 & 3.99 \\
\hline Nb ppm & 23.38 & 9.29 & 8.55 & 9.88 & 11.13 \\
\hline Y ppm & 61.63 & 44.71 & 49.46 & 47.15 & 51.92 \\
\hline Hf ppm & 9.12 & 5.59 & 4.38 & 5.12 & 5.46 \\
\hline Ta ppm & 1.48 & 0.59 & 0.57 & 0.64 & 0.74 \\
\hline U ppm & 2.79 & 2.52 & 1.29 & 1.74 & 2.01 \\
\hline $\mathrm{Pb}$ ppm & 14.49 & 10.81 & 6.68 & 8.73 & 8.84 \\
\hline Rb ppm & 78.7 & 60.0 & 28.7 & 35.0 & 47.3 \\
\hline Cs ppm & 1.17 & 2.35 & 1.21 & 4.93 & 2.45 \\
\hline Sr ppm & 280 & 297 & 247 & 233 & 318 \\
\hline Sc ppm & 23.5 & 17.2 & 28.0 & 21.4 & 25.2 \\
\hline Zr ppm & 356 & 210 & 161 & 193 & 202 \\
\hline
\end{tabular}




\begin{tabular}{|c|c|c|c|c|c|}
\hline Sample ID & MC-98-16 & MC-100-16 & MC-106-16 & MC3C & $\mathrm{MC} 13 \mathrm{C}$ \\
\hline Dataset & Cruz, 2016 & Cruz, 2017 & Cruz, 2017 & Cruz, 2017 & Cruz, 2017 \\
\hline Unit & & Hunter Creek & Hunter Creek & Hunter Creek & Hunter Creek \\
\hline $\begin{array}{l}\text { Icelandite } \\
\text { Group }\end{array}$ & $\begin{array}{l}\text { Group } 2 \text { low } \\
\text { TiO2 }\end{array}$ & $\begin{array}{c}\text { Group } 2 \text { low } \\
\text { TiO2 }\end{array}$ & $\begin{array}{c}\text { Group } 2 \text { low } \\
\text { TiO2 }\end{array}$ & $\begin{array}{c}\text { Group } 2 \text { low } \\
\text { TiO2 }\end{array}$ & $\begin{array}{c}\text { Group } 2 \text { low } \\
\text { TiO2 }\end{array}$ \\
\hline Quad & $\begin{array}{l}\text { Rastus } \\
\text { Mountain }\end{array}$ & Eldorado Pass & $\begin{array}{l}\text { Rastus } \\
\text { Mountain }\end{array}$ & $\begin{array}{l}\text { Clevenger } \\
\text { Butte }\end{array}$ & $\begin{array}{l}\text { Rastus } \\
\text { Mountain }\end{array}$ \\
\hline Easting $(m)$ & 409980.37 & 410363.82 & 409638.45 & 409254.51 & 407381.59 \\
\hline Northing $(m)$ & 4902902.89 & 4902342.16 & 4909351.14 & 4899480.09 & 4900317.29 \\
\hline \multicolumn{6}{|c|}{ XRF Normalized Wt. \% } \\
\hline $\mathrm{SiO2}$ & 62.23 & 60.58 & 62.02 & 59.42 & 60.60 \\
\hline TiO2 & 1.08 & 1.32 & 1.44 & 1.42 & 1.24 \\
\hline Al2O3 & 14.08 & 14.56 & 15.45 & 14.51 & 14.36 \\
\hline FeO* & 9.84 & 10.25 & 7.81 & 10.42 & 10.29 \\
\hline MnO & 0.20 & 0.20 & 0.14 & 0.20 & 0.21 \\
\hline MgO & 1.15 & 1.47 & 1.39 & 1.92 & 1.46 \\
\hline $\mathrm{CaO}$ & 4.73 & 4.84 & 4.98 & 5.51 & 5.11 \\
\hline $\mathrm{Na2O}$ & 4.01 & 4.03 & 3.74 & 4.00 & 4.22 \\
\hline K2O & 2.26 & 2.23 & 2.52 & 1.95 & 2.00 \\
\hline P2O5 & 0.421 & 0.516 & 0.509 & 0.658 & 0.520 \\
\hline \multicolumn{6}{|c|}{ XRF Trace (ppm) } \\
\hline $\mathrm{Ni}$ & 2 & 4 & 2 & 6 & 4 \\
\hline $\mathrm{Cr}$ & 0 & 2 & 0 & 0 & 0 \\
\hline Sc & 28 & 30 & 21 & 30 & 32 \\
\hline v & 35 & 67 & 113 & 63 & 46 \\
\hline $\mathrm{Ba}$ & 873 & 900 & 1024 & 779 & 824 \\
\hline $\mathbf{R b}$ & 47 & 52 & 59 & 44 & 47 \\
\hline $\mathrm{Sr}$ & 277 & 299 & 323 & 310 & 300 \\
\hline $\mathrm{Zr}$ & 208 & 192 & 208 & 178 & 192 \\
\hline $\mathbf{Y}$ & 48 & 47 & 52 & 47 & 47 \\
\hline Nb & 10.1 & 10.7 & 10.0 & 10.1 & 9.9 \\
\hline Ga & 20 & 20 & 24 & 18 & 20 \\
\hline $\mathrm{Cu}$ & 4 & 10 & 6 & 8 & 6 \\
\hline $\mathrm{Zn}$ & 167 & 179 & 223 & 165 & 173 \\
\hline $\mathrm{Pb}$ & 11 & 9 & 9 & 7 & 8 \\
\hline La & 24 & 24 & 23 & 22 & 26 \\
\hline $\mathrm{Ce}$ & 58 & 54 & 56 & 52 & 55 \\
\hline Th & 5 & 5 & 5 & 4 & 4 \\
\hline Nd & 32 & 30 & 33 & 31 & 33 \\
\hline U & 2 & 4 & 3 & 1 & 3 \\
\hline
\end{tabular}




\begin{tabular}{|c|c|c|c|c|c|}
\hline Sample ID & MS-98-16 & MC-100-16 & MC-106-16 & Мс3С & $\mathrm{MC} 13 \mathrm{C}$ \\
\hline Easting (m) & 409980.37 & 410363.82 & 409638.45 & 409254.51 & 407381.59 \\
\hline $\begin{array}{c}\text { Northing }(m) \\
\text { Unit }\end{array}$ & 4902902.89 & $\begin{array}{c}4902342.16 \\
\text { Hunter Creek }\end{array}$ & $\begin{array}{c}4909351.14 \\
\text { Hunter Creek }\end{array}$ & $\begin{array}{l}4899480.09 \\
\text { Hunter Creek }\end{array}$ & $\begin{array}{c}4900317.29 \\
\text { Hunter Creek }\end{array}$ \\
\hline \multicolumn{6}{|c|}{ ICP-MS Trace (ppm) } \\
\hline La ppm & 23.96 & 23.95 & 26.23 & 23.24 & 23.45 \\
\hline Ce ppm & 52.65 & 52.57 & 53.39 & 51.23 & 52.25 \\
\hline Pr ppm & 7.19 & 7.20 & 7.56 & 7.16 & 7.19 \\
\hline Nd ppm & 31.38 & 31.43 & 32.42 & 31.41 & 31.24 \\
\hline Sm ppm & 7.85 & 7.95 & 8.11 & 7.96 & 7.88 \\
\hline Eu ppm & 2.15 & 2.15 & 1.86 & 2.23 & 2.23 \\
\hline Gd ppm & 8.19 & 8.26 & 8.57 & 8.40 & 8.25 \\
\hline Tb ppm & 1.40 & 1.39 & 1.49 & 1.38 & 1.41 \\
\hline Dy ppm & 8.73 & 8.84 & 9.43 & 8.84 & 8.85 \\
\hline Ho ppm & 1.87 & 1.85 & 2.01 & 1.84 & 1.83 \\
\hline Er ppm & 5.15 & 5.06 & 5.60 & 4.97 & 5.01 \\
\hline Tm ppm & 0.76 & 0.74 & 0.81 & 0.71 & 0.71 \\
\hline Yb ppm & 4.77 & 4.66 & 5.10 & 4.42 & 4.67 \\
\hline Lu ppm & 0.79 & 0.74 & 0.83 & 0.72 & 0.73 \\
\hline Ba ppm & 872 & 919 & 1040 & 765 & 824 \\
\hline Th ppm & 4.67 & 4.56 & 5.34 & 4.07 & 4.29 \\
\hline Nb ppm & 10.28 & 10.41 & 9.76 & 9.45 & 10.11 \\
\hline Y ppm & 47.54 & 47.63 & 52.21 & 46.87 & 46.87 \\
\hline Hf ppm & 5.48 & 5.34 & 5.77 & 4.90 & 5.19 \\
\hline Ta ppm & 0.65 & 0.70 & 0.67 & 0.62 & 0.65 \\
\hline U ppm & 2.25 & 2.27 & 2.71 & 1.95 & 2.10 \\
\hline Pb ppm & 9.45 & 8.45 & 8.77 & 7.43 & 8.03 \\
\hline Rb ppm & 47.1 & 52.3 & 58.7 & 43.7 & 45.2 \\
\hline Cs ppm & 2.50 & 2.37 & 2.38 & 1.95 & 2.10 \\
\hline Sr ppm & 275 & 305 & 328 & 315 & 304 \\
\hline Sc ppm & 28.8 & 30.8 & 22.1 & 28.5 & 32.8 \\
\hline Zr ppm & 208 & 199 & 217 & 180 & 195 \\
\hline
\end{tabular}




\begin{tabular}{|c|c|c|}
\hline Sample ID & MC25A & MC43A \\
\hline Dataset & Cruz, 2017 & Cruz, 2017 \\
\hline Unit & Hunter Creek & Hunter Creek \\
\hline Icelandite & Group 2 high & Group 2 high \\
\hline Group & $\mathrm{TiO} 2$ & TiO2 \\
\hline Quad & Castle Rock & Castle Rock \\
\hline Easting $(m)$ & 405873.30 & 405271.41 \\
\hline Northing (m) & 4884196.71 & 4881305.80 \\
\hline \multicolumn{3}{|c|}{ XRF Normalized Wt. \% } \\
\hline SiO2 & 59.32 & 58.79 \\
\hline TiO2 & 1.77 & 1.81 \\
\hline $\mathrm{Al} 203$ & 15.47 & 15.47 \\
\hline FeO* & 8.17 & 9.61 \\
\hline MnO & 0.17 & 0.15 \\
\hline MgO & 2.51 & 1.75 \\
\hline $\mathrm{CaO}$ & 5.96 & 5.61 \\
\hline $\mathrm{Na2O}$ & 3.79 & 4.30 \\
\hline K2O & 2.09 & 1.73 \\
\hline P2O5 & 0.765 & 0.785 \\
\hline \multicolumn{3}{|c|}{ XRF Trace (ppm) } \\
\hline $\mathrm{Ni}$ & 2 & 4 \\
\hline $\mathrm{Cr}$ & 0 & 0 \\
\hline Sc & 24 & 25 \\
\hline $\mathbf{v}$ & 132 & 140 \\
\hline $\mathrm{Ba}$ & 896 & 715 \\
\hline $\mathbf{R b}$ & 35 & 36 \\
\hline Sr & 358 & 354 \\
\hline $\mathrm{Zr}$ & 194 & 186 \\
\hline $\mathbf{Y}$ & 53 & 50 \\
\hline $\mathbf{N b}$ & 11.5 & 11.0 \\
\hline Ga & 19 & 20 \\
\hline $\mathrm{Cu}$ & 4 & 5 \\
\hline $\mathrm{Zn}$ & 158 & 159 \\
\hline $\mathrm{Pb}$ & 8 & 7 \\
\hline La & 23 & 25 \\
\hline $\mathrm{Ce}$ & 48 & 53 \\
\hline Th & 3 & 4 \\
\hline Nd & 33 & 36 \\
\hline $\mathbf{u}$ & 2 & 2 \\
\hline
\end{tabular}




\begin{tabular}{ccc}
\hline \hline Sample ID & MC25A & MC43A \\
Easting (m) & 405873.30 & 405271.41 \\
Northing (m) & 4884196.71 & 4881305.80 \\
Unit & Hunter Creek & Hunter Creek \\
\hline ICP-MS Trace $(p p m)$ & & \\
La ppm & 25.14 & 25.57 \\
Ce ppm & 53.26 & 51.23 \\
Pr ppm & 7.78 & 8.11 \\
Nd ppm & 34.14 & 35.99 \\
Sm ppm & 8.54 & 8.92 \\
Eu ppm & 2.45 & 2.59 \\
Gd ppm & 9.26 & 9.69 \\
Tb ppm & 1.54 & 1.60 \\
Dy ppm & 10.00 & 9.95 \\
Ho ppm & 2.05 & 2.03 \\
Er ppm & 5.46 & 5.45 \\
Tm ppm & 0.79 & 0.79 \\
Yb ppm & 4.94 & 4.85 \\
Lu ppm & 0.78 & 0.77 \\
Ba ppm & 901 & 711 \\
Th ppm & 3.34 & 3.20 \\
Nb ppm & 11.29 & 11.00 \\
Y ppm & 53.43 & 50.10 \\
Hf ppm & 5.22 & 5.07 \\
Ta ppm & 0.72 & 0.71 \\
U ppm & 1.55 & 1.47 \\
Pb ppm & 6.95 & 6.73 \\
Rb ppm & 33.6 & 34.3 \\
Cs ppm & 1.42 & 1.63 \\
Sr ppm & 356 & 353 \\
Sc ppm & 23.4 & 23.7 \\
Zr ppm & 198 & 191 \\
\hline \hline & & \\
\hline
\end{tabular}




\section{Appendix B: SEM-EDS Data}

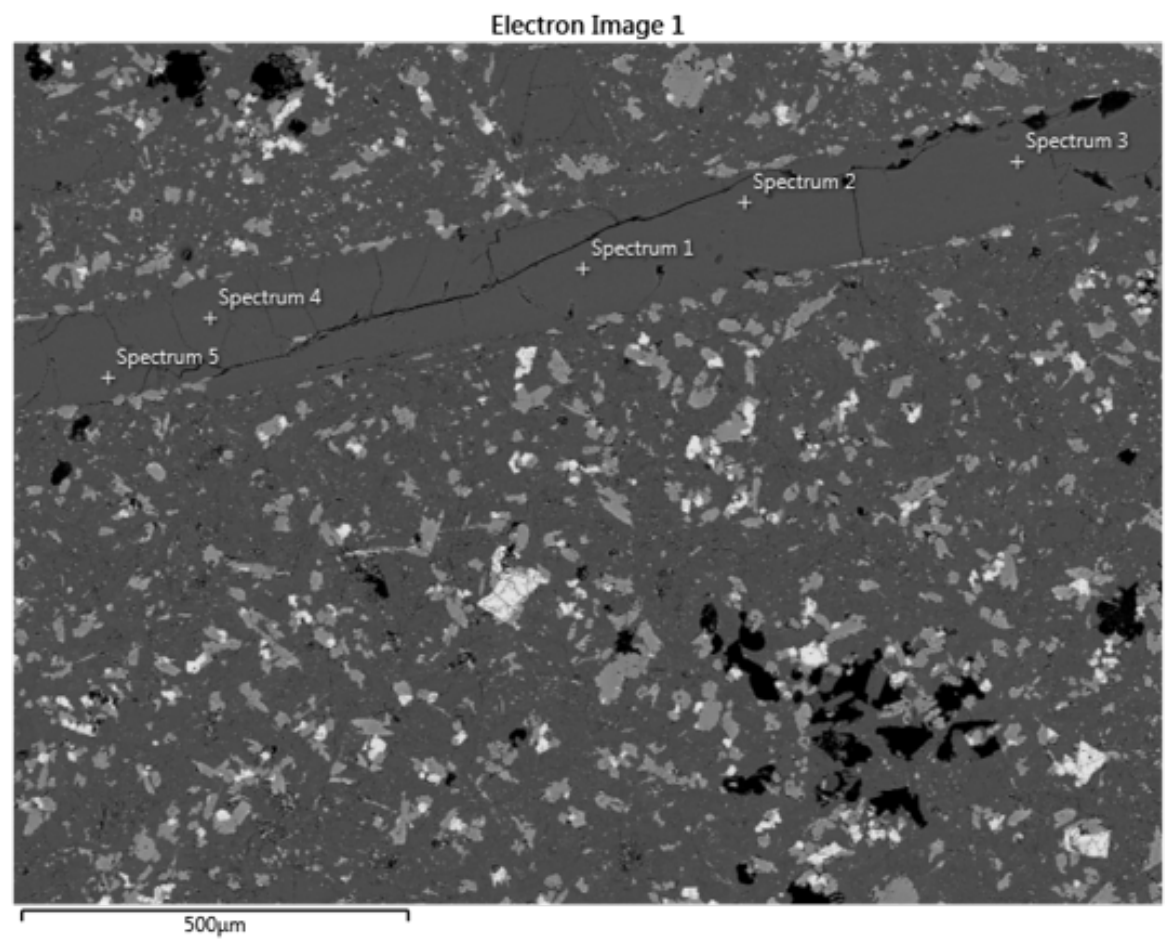

Figure B-1. Electron images of site 1 of sample MAC-17-04a.

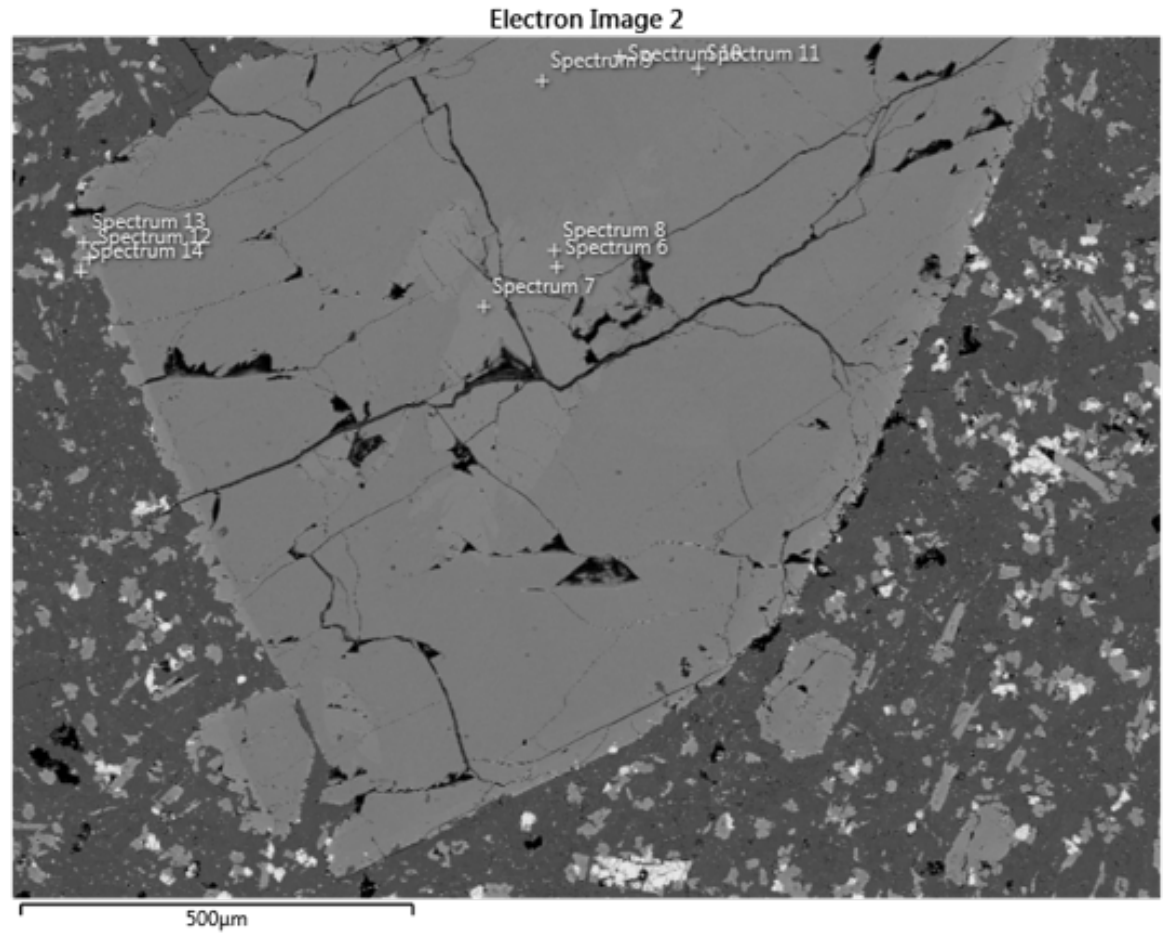

Figure B-2. Electron images of site 2 of sample MAC-17-04a. 
Electron Image 3

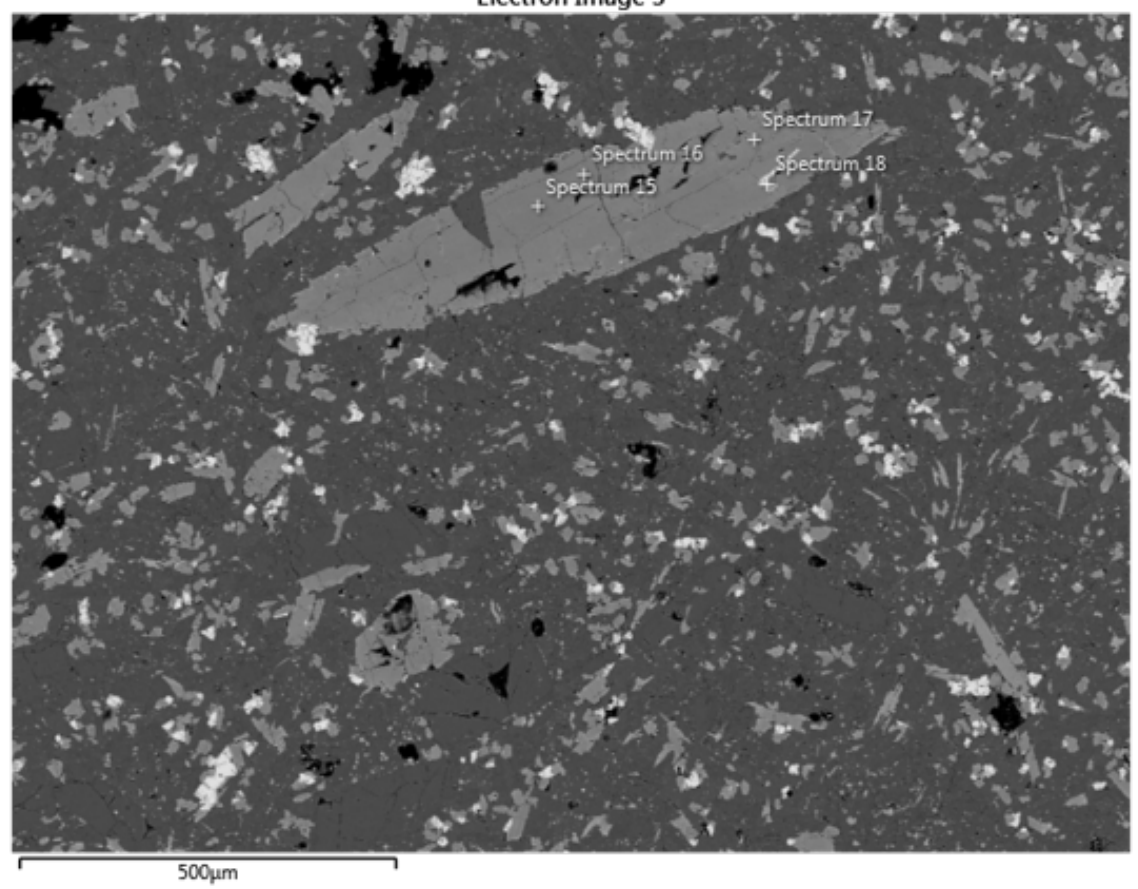

Figure B-3 Electron images of site 3 of sample MAC-17-04a.

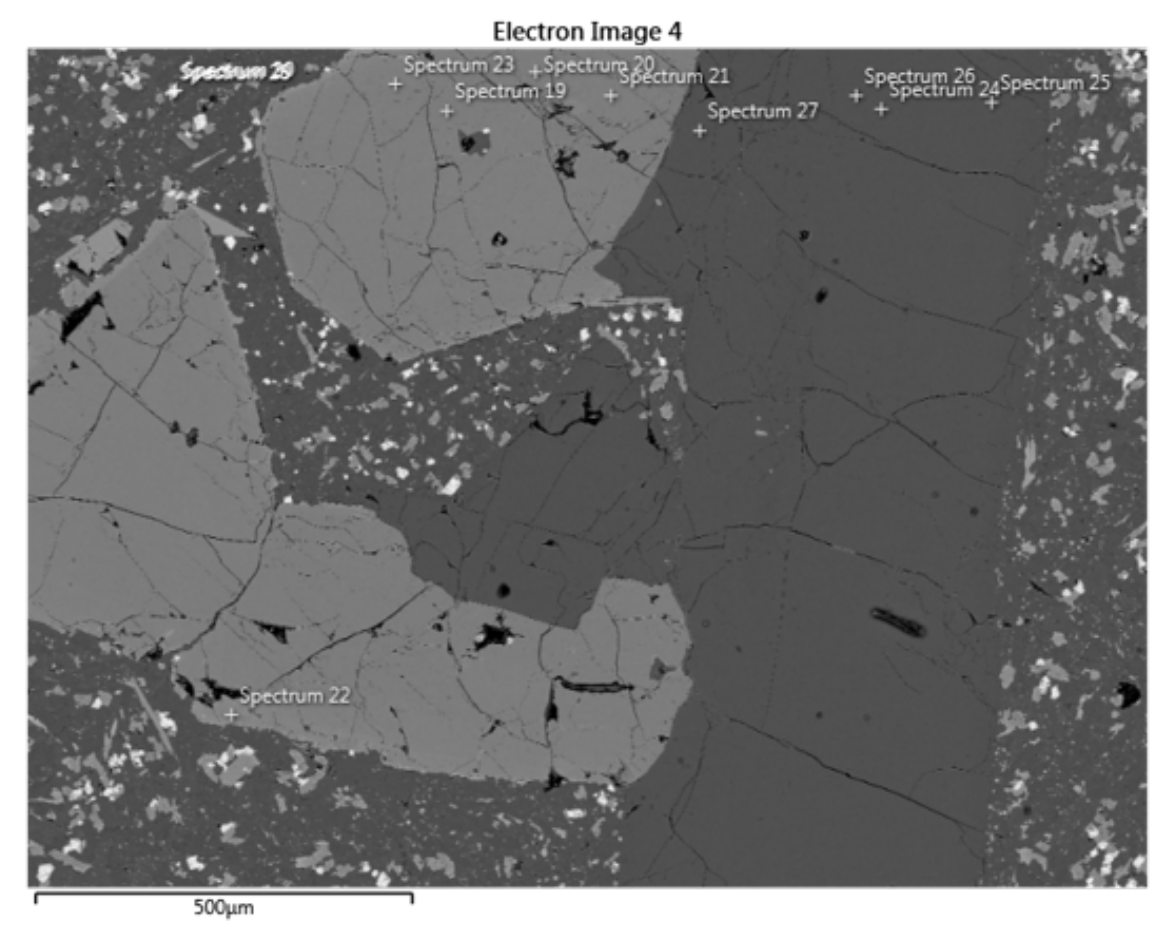

Figure B-4. Electron images of site 4 of sample MAC-17-04a. 


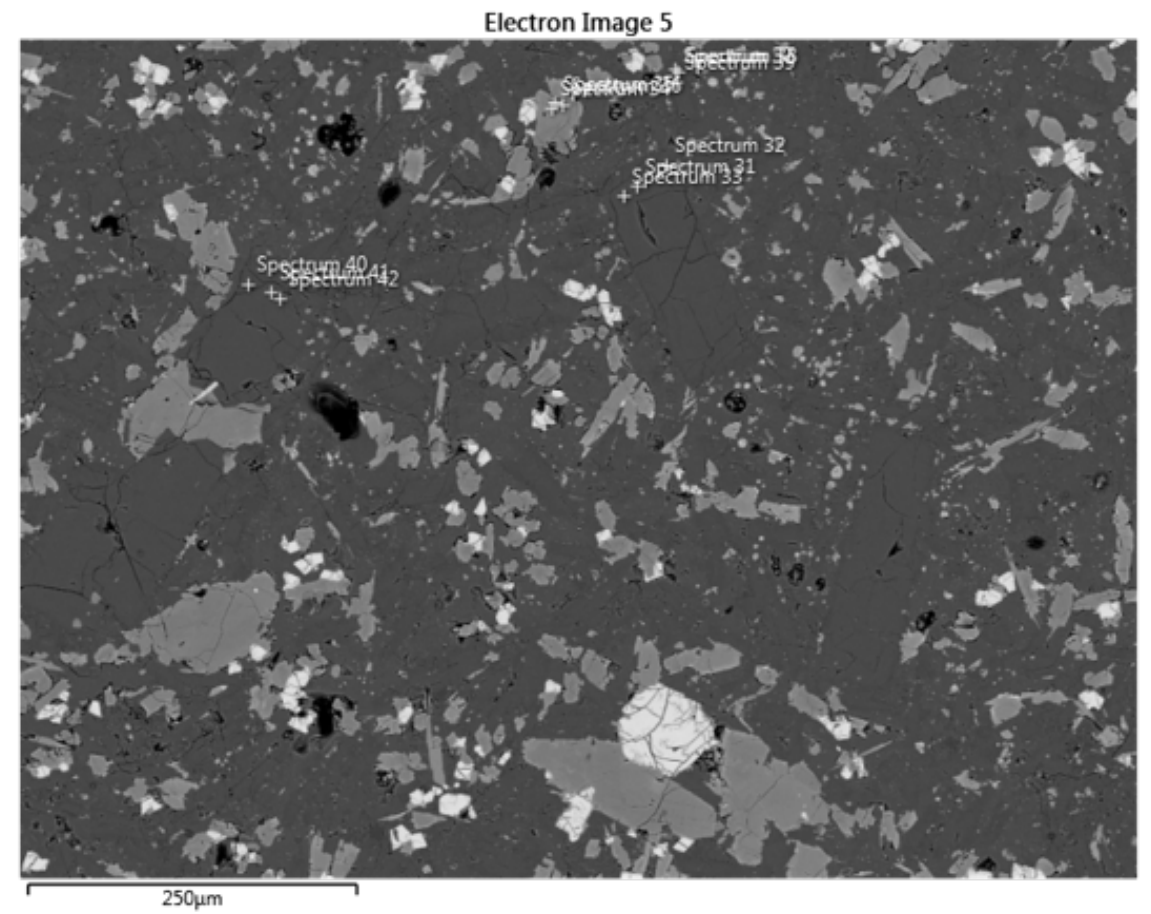

Figure B-5. Electron images of site 5 of sample MAC-17-04a.

Table B-1. Selected EDS spectra for sites 1-5 of MAC-17-04a.

\begin{tabular}{ccccccccccccc}
\hline MAC 17-04a & $\mathrm{SiO}_{2}$ & $\mathrm{TiO}_{2}$ & $\mathrm{Al}_{2} \mathrm{O}_{3}$ & $\mathrm{FeO}$ & $\mathrm{MnO}$ & $\mathrm{MgO}$ & $\mathrm{CaO}$ & $\mathrm{Na}_{2} \mathrm{O}$ & $\mathrm{K}_{2} \mathrm{O}$ & $\mathrm{P}_{2} \mathrm{O}_{5}$ & Total & Phase \\
\hline Spectrum 1 & 55.32 & & 27.17 & 0.35 & & & 9.53 & 5.38 & 0.22 & & 97.96 & Plagioclase \\
Spectrum 2 & 55.09 & & 27.21 & 0.60 & & & 9.79 & 5.12 & 0.30 & 98.12 & Plagioclase \\
Spectrum 3 & 54.62 & & 26.92 & 0.59 & & & 9.68 & 5.27 & 0.30 & 97.39 & Plagioclase \\
Spectrum 4 & 55.11 & & 26.85 & 0.49 & & & 9.77 & 5.38 & 0.35 & 97.94 & Plagioclase \\
Spectrum 5 & 55.43 & & 26.68 & 0.71 & & & 9.50 & 5.55 & 0.27 & 98.14 & Plagioclase \\
Spectrum 8 & 49.74 & 0.50 & 1.00 & 23.05 & 0.71 & 15.47 & 6.77 & & & 97.25 & Pyroxene \\
Spectrum 11 & 49.83 & 0.82 & 1.70 & 16.02 & 0.59 & 12.82 & 16.22 & 0.32 & & & 98.31 & Pyroxene \\
Spectrum 13 & 49.31 & 0.53 & 0.81 & 26.44 & 0.88 & 14.48 & 5.02 & 0.22 & & & 97.69 & Pyroxene \\
Spectrum 17 & 48.58 & 0.73 & 1.51 & 21.77 & 0.63 & 13.02 & 11.07 & 0.24 & & 97.56 & Pyroxene \\
Spectrum 20 & 50.49 & 0.68 & 1.51 & 15.57 & 0.67 & 12.88 & 16.47 & 0.26 & & 98.53 & Pyroxene \\
Spectrum 23 & 49.97 & 0.75 & 1.40 & 17.38 & 0.59 & 13.40 & 14.27 & 0.32 & & & 98.09 & Pyroxene \\
Spectrum 25 & 55.30 & & 26.75 & 0.46 & & & 9.70 & 5.43 & 0.31 & & 97.96 & Plagioclase \\
Spectrum 27 & 55.32 & & 27.15 & 0.51 & & & 9.70 & 5.31 & 0.34 & & 98.33 & Plagioclase \\
Spectrum 28 & 48.54 & 0.58 & 1.04 & 29.09 & 0.99 & 9.54 & 9.07 & 0.32 & & & 99.17 & Pyroxene \\
Spectrum 32 & 56.24 & & 26.04 & 0.64 & & & 8.48 & 5.98 & 0.41 & & 97.80 & Plagioclase \\
Spectrum 34 & 49.10 & 0.67 & 0.94 & 27.56 & 1.03 & 13.83 & 4.46 & & & & 97.59 & Pyroxene \\
Spectrum 38 & 57.55 & 0.38 & 24.68 & 0.81 & & & 7.21 & 6.66 & 0.55 & & 97.84 & Plagioclase \\
Spectrum 42 & 56.26 & & 26.06 & 0.67 & & & 8.42 & 5.85 & 0.42 & & 97.68 & Plagioclase \\
\hline \hline
\end{tabular}


Electron Image 1

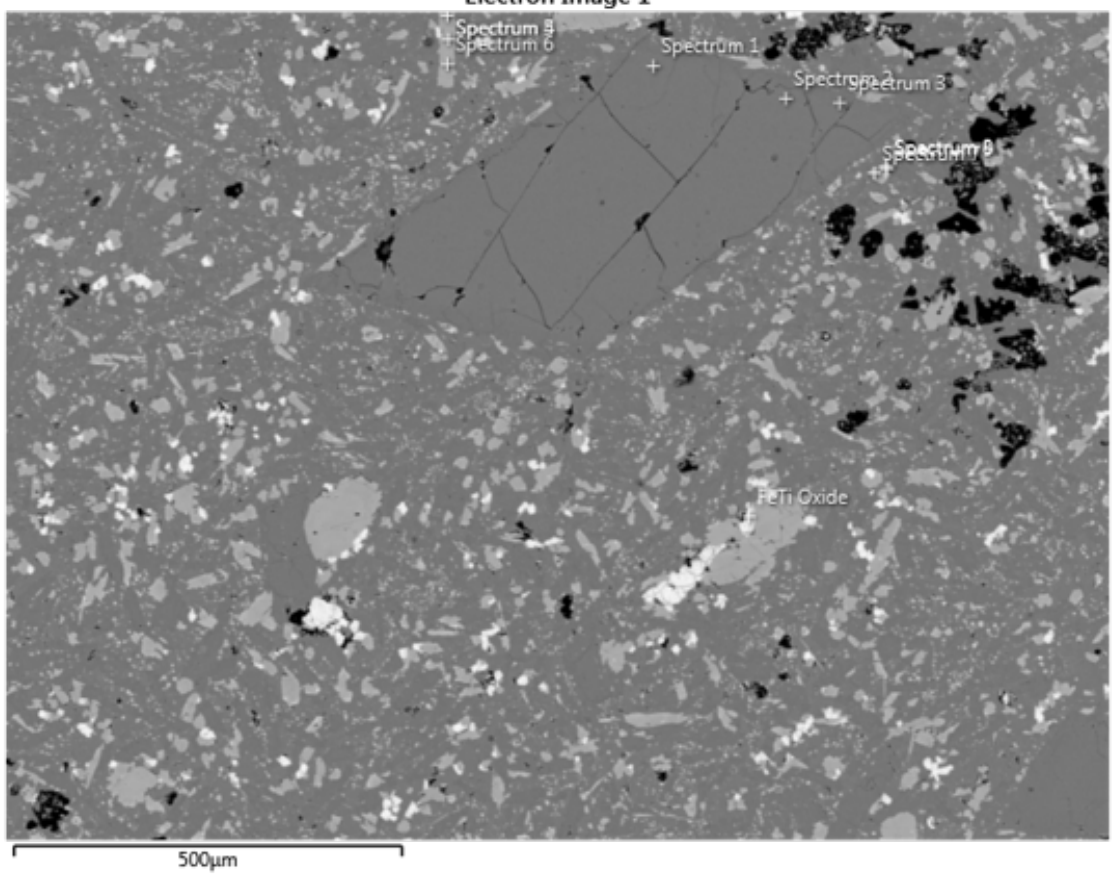

Figure B-6. Electron images of site 1 of sample MAC-17-08.

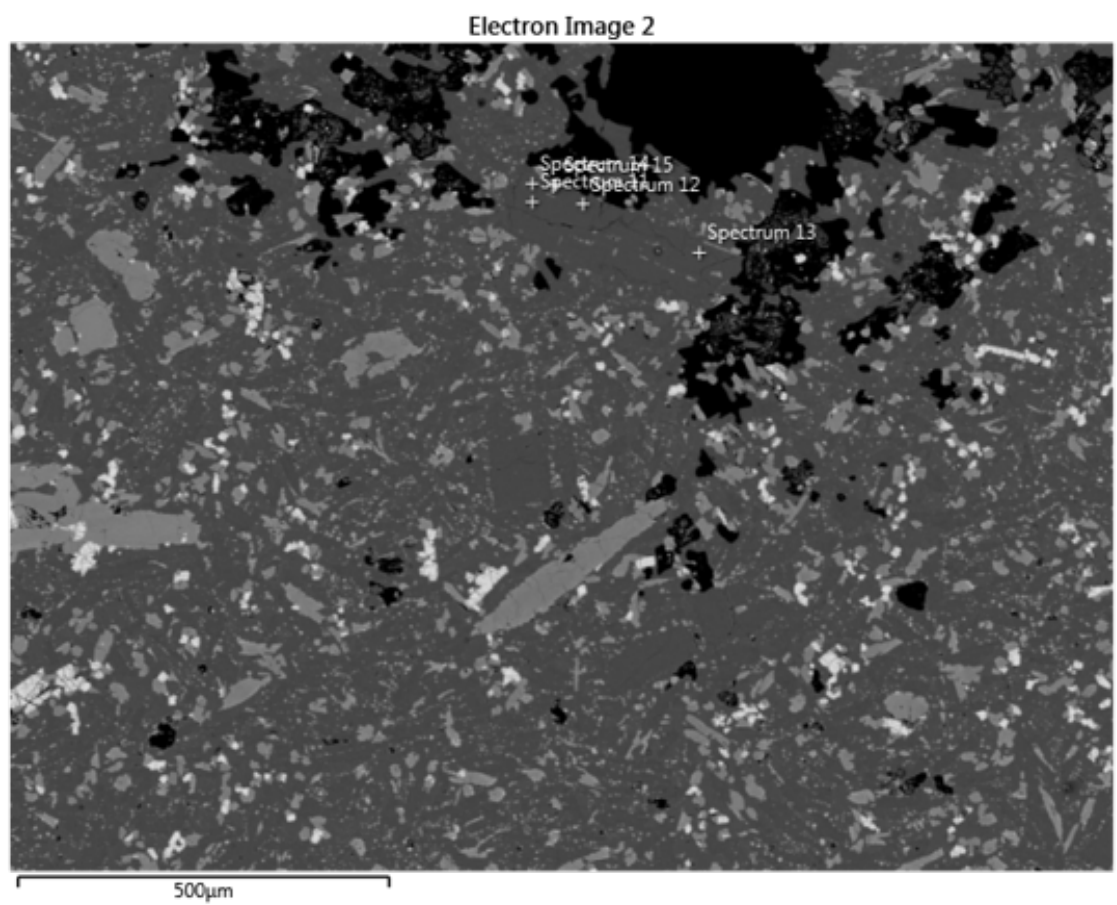

Figure B-7. Electron images of site 2 of sample MAC-17-08. 
Electron Image 3

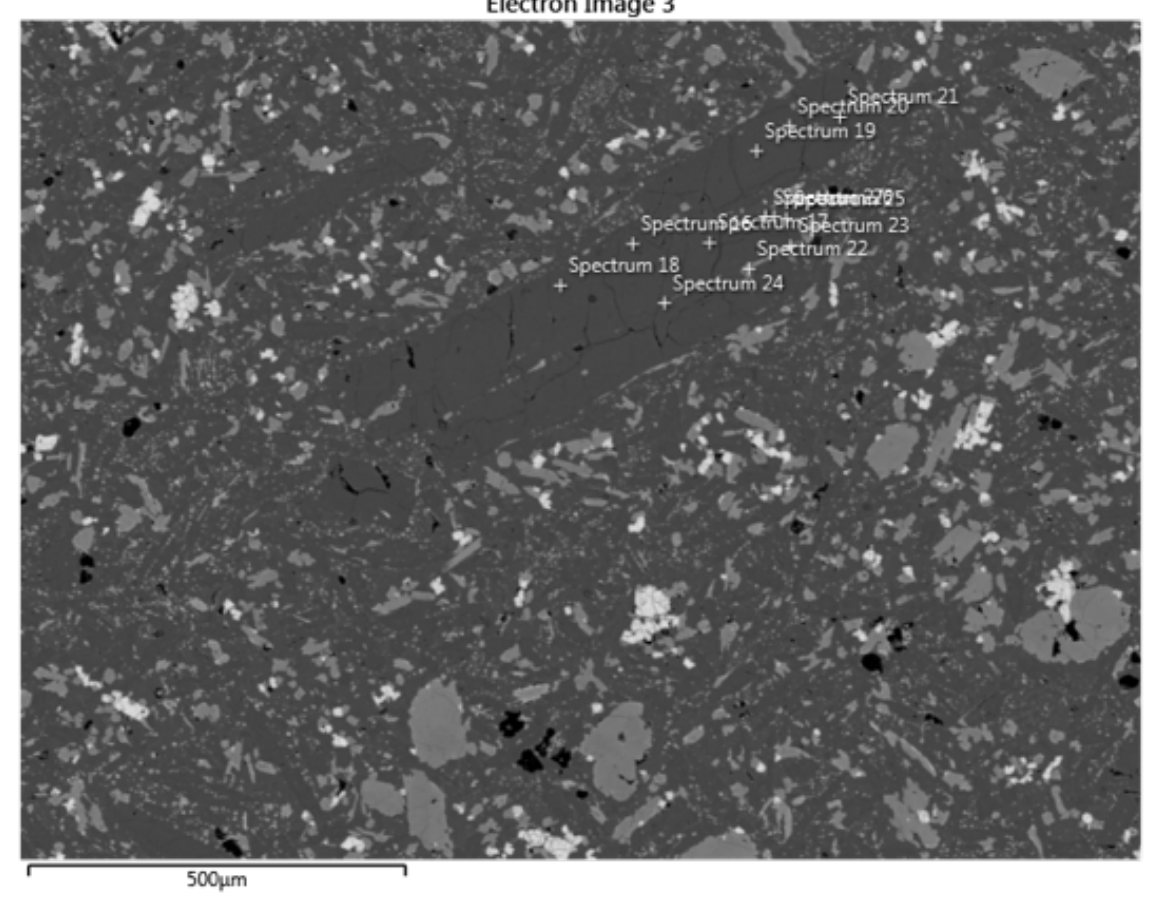

Figure B-8. Electron images of site 3 of sample MAC-17-08.

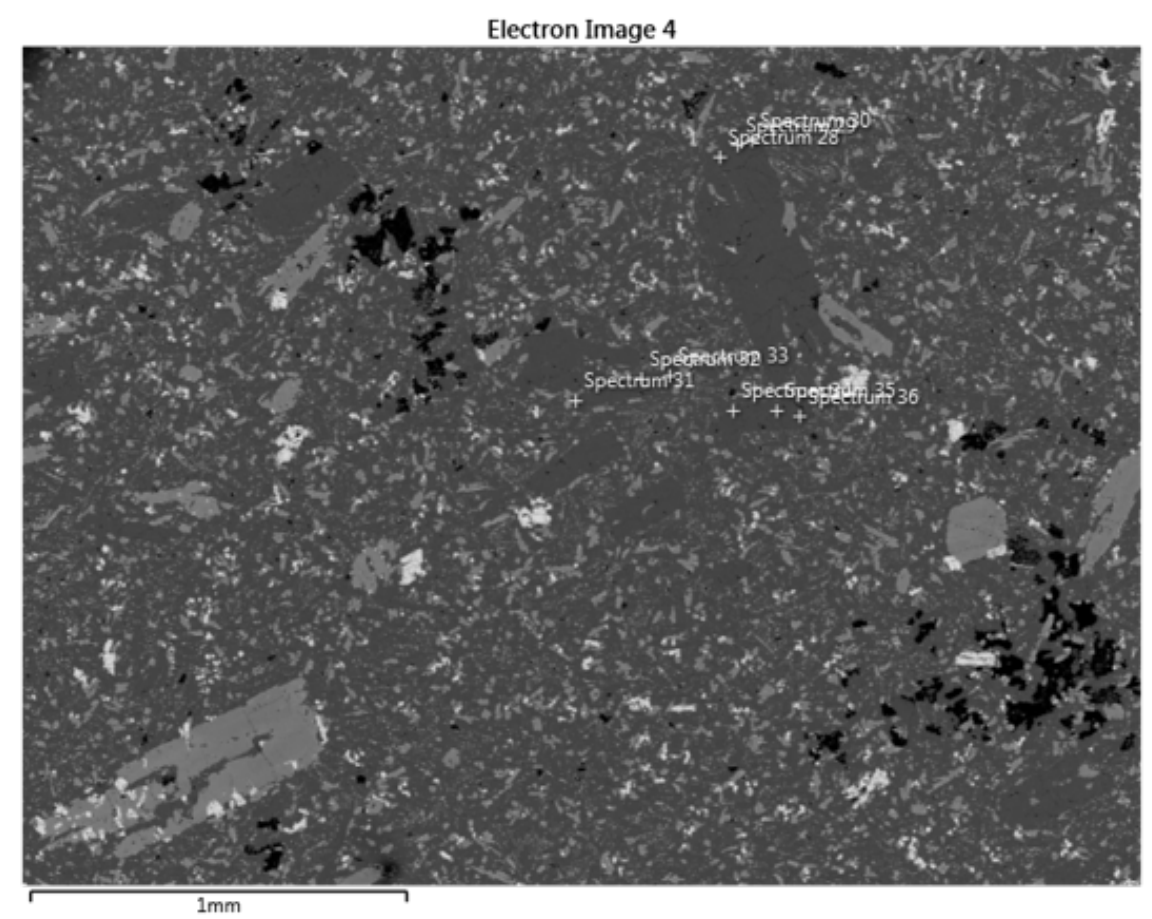

Figure B-9. Electron images of site 4 of sample MAC-17-08. 
Electron Image 5

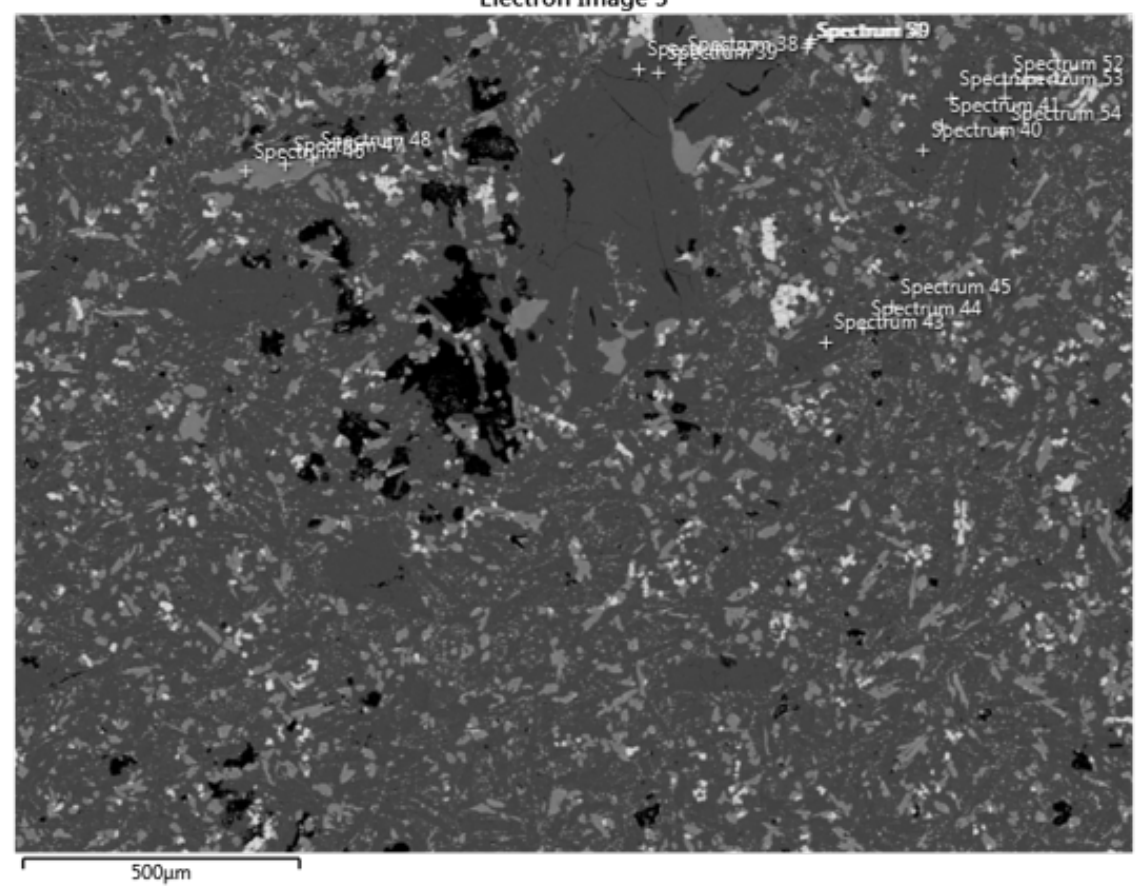

Figure B-10. Electron images of site 5 of sample MAC-17-08.

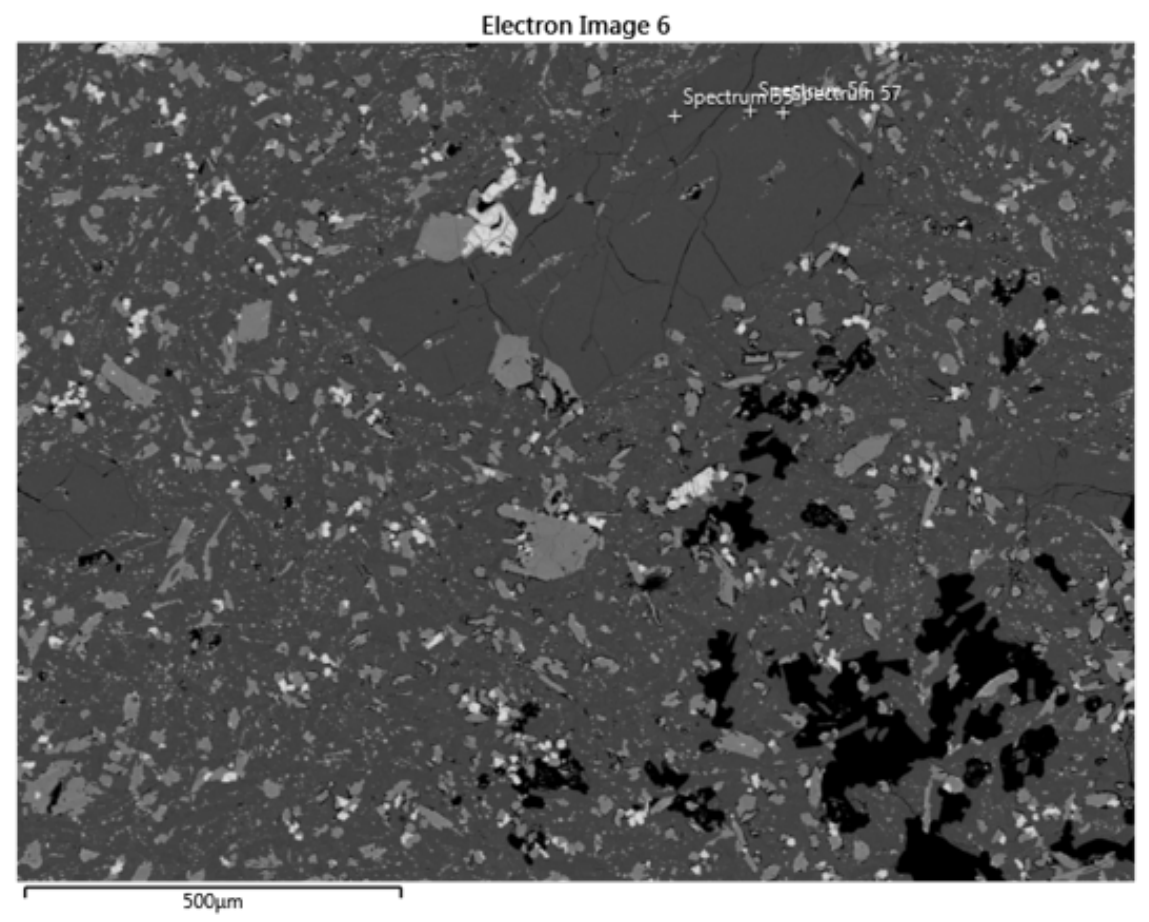

Figure B-11. Electron images of site 6 of sample MAC-17-08. 


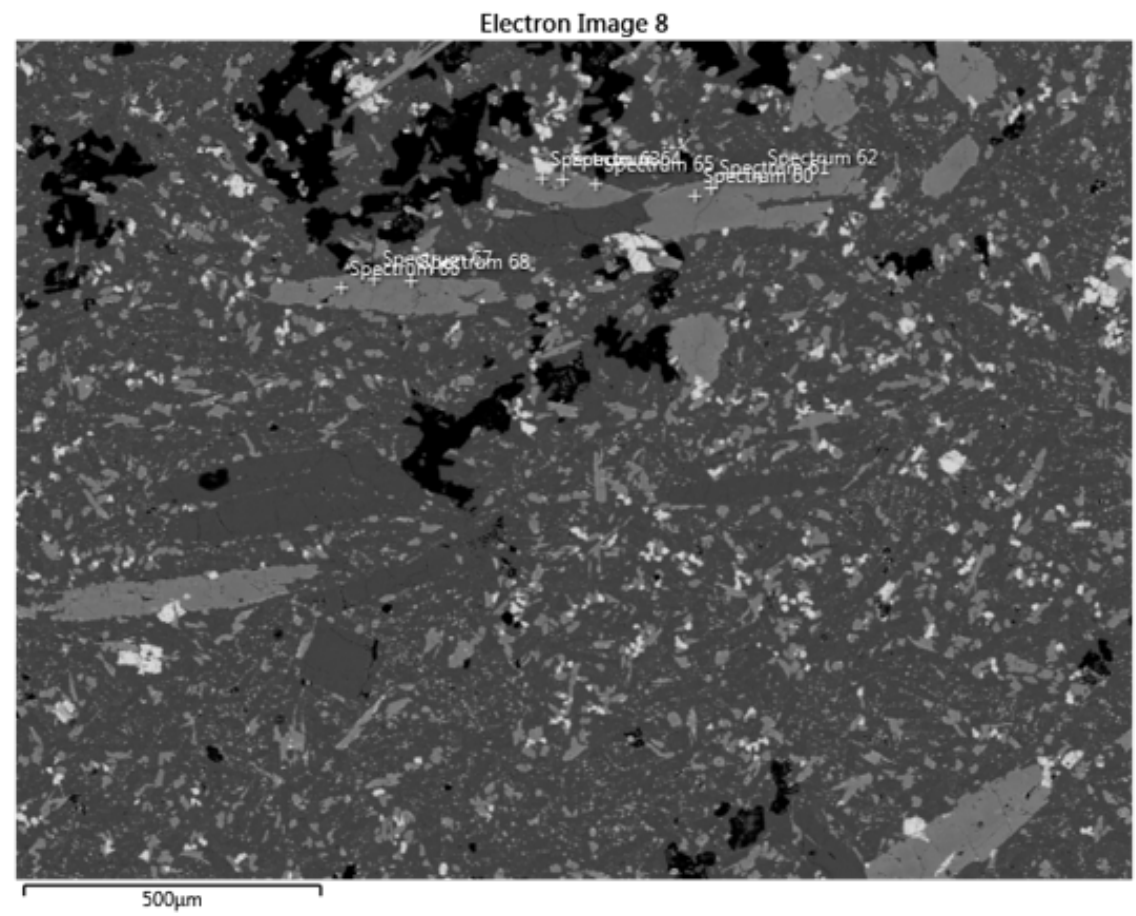

Figure B-12. Electron images of site 8 of sample MAC-17-08.

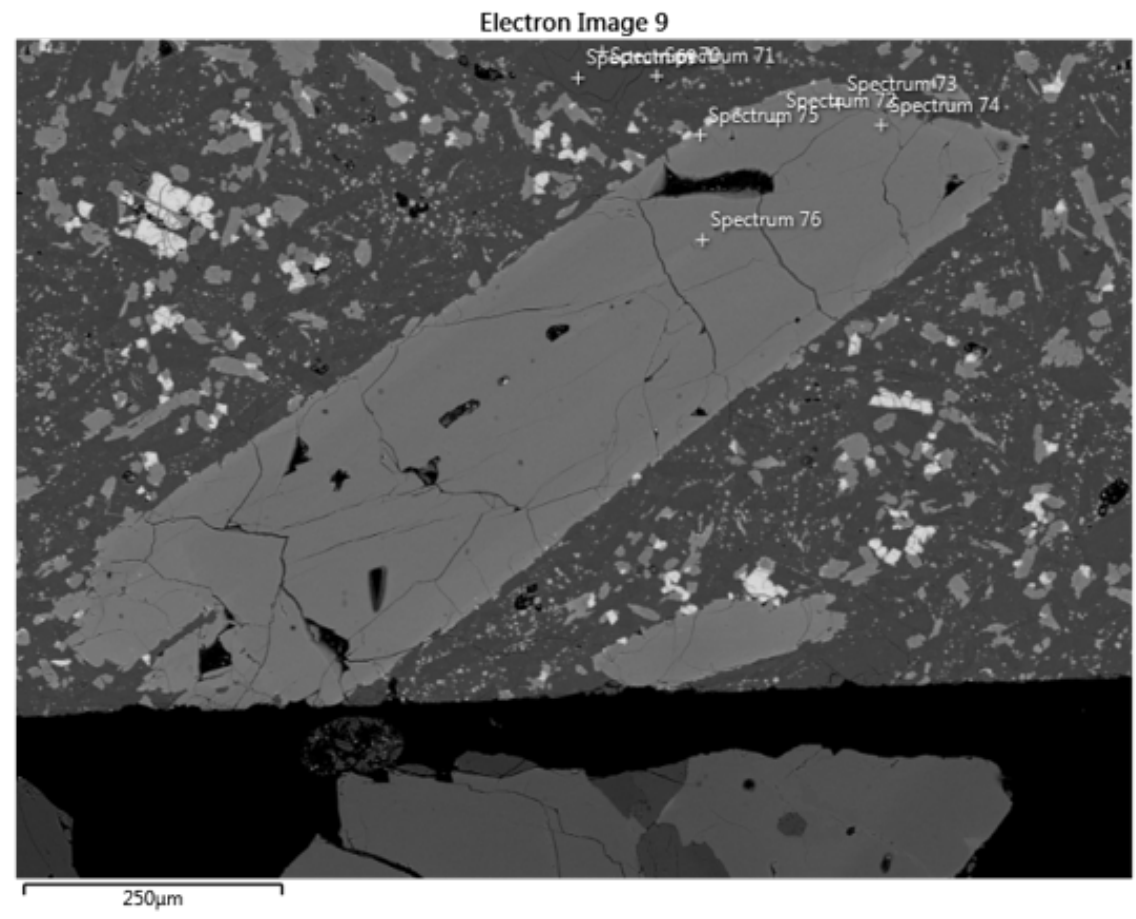

Figure B-13. Electron images of site 9 of sample MAC-17-08. 
Table B-2. Selected EDS spectra for sites 1-9 of MAC-17-08.

\begin{tabular}{lcccccccccccc}
\hline \hline MAC 17-08 & $\mathrm{SiO}_{2}$ & $\mathrm{TiO}_{2}$ & $\mathrm{Al}_{2} \mathrm{O}_{3}$ & $\mathrm{FeO}$ & $\mathrm{MnO}$ & $\mathrm{MgO}$ & $\mathrm{CaO}$ & $\mathrm{Na}_{2} \mathrm{O}$ & $\mathrm{K}_{2} \mathrm{O}$ & $\mathrm{P}_{2} \mathrm{O}_{5}$ & Total & Phase \\
\hline Spectrum 1 & 55.82 & & 27.28 & 0.69 & & & 9.66 & 5.53 & 0.36 & & 99.35 & Plagioclase \\
Spectrum 5 & 49.60 & 0.73 & 1.20 & 20.87 & 0.81 & 12.07 & 13.93 & 0.37 & & 0.87 & 100.45 & Pyroxene \\
Spectrum 11 & 55.90 & & 26.47 & 0.79 & & & 9.06 & 5.74 & 0.40 & 98.38 & Plagioclase \\
Spectrum 12 & 56.46 & & 25.46 & 0.49 & & & 8.16 & 6.06 & 0.48 & 97.11 & Plagioclase \\
Spectrum 14 & 56.70 & & 25.55 & 0.54 & & & 8.28 & 6.05 & 0.42 & 97.54 & Plagioclase \\
Spectrum 15 & 57.40 & & 25.79 & 0.70 & & & 8.11 & 6.35 & 0.53 & & 98.90 & Plagioclase \\
Spectrum 19 & 55.65 & & 26.15 & 0.58 & & & 8.83 & 5.72 & 0.31 & & 97.24 & Plagioclase \\
Spectrum 20 & 56.26 & & 26.18 & 0.53 & & & 8.63 & 5.92 & 0.37 & & 97.89 & Plagioclase \\
Spectrum 21 & 56.54 & & 26.20 & 0.68 & & & 8.52 & 5.85 & 0.48 & & 98.27 & Plagioclase \\
Spectrum 42 & 57.46 & & 26.16 & 0.66 & & & 8.80 & 6.04 & 0.46 & & 99.57 & Plagioclase \\
Spectrum 47 & 49.01 & 1.22 & 2.94 & 18.31 & 0.45 & 11.55 & 16.45 & & & & 99.94 & Pyroxene \\
Spectrum 49 & 50.71 & 0.63 & 0.81 & 27.26 & 0.79 & 13.20 & 6.53 & & & & 99.93 & Pyroxene \\
Spectrum 53 & 57.04 & & 26.37 & 0.62 & & & 8.84 & 5.83 & 0.43 & & 99.14 & Plagioclase \\
Spectrum 56 & 57.05 & & 26.72 & 0.64 & & & 9.05 & 6.00 & 0.36 & & 99.82 & Plagioclase \\
Spectrum 60 & 50.52 & 0.76 & 1.63 & 17.39 & & 12.19 & 16.67 & 0.30 & & & 99.46 & Pyroxene \\
Spectrum 64 & 50.15 & 0.79 & 1.71 & 20.54 & 0.74 & 12.75 & 13.11 & & & & 99.78 & Pyroxene \\
Spectrum 68 & 49.84 & 1.04 & 2.06 & 19.76 & 0.51 & 12.54 & 13.89 & & & & 99.63 & Pyroxene \\
Spectrum 70 & 56.86 & & 26.95 & 0.51 & & & 9.09 & 5.85 & 0.39 & & 99.65 & Plagioclase \\
Spectrum 72 & 49.81 & 1.00 & 1.71 & 16.45 & 0.51 & 12.52 & 16.44 & 0.29 & & & 98.72 & Pyroxene \\
Spectrum 76 & 50.45 & 0.42 & 0.88 & 24.93 & 0.83 & 16.48 & 4.65 & 0.20 & & & 98.83 & Pyroxene \\
\hline \hline
\end{tabular}




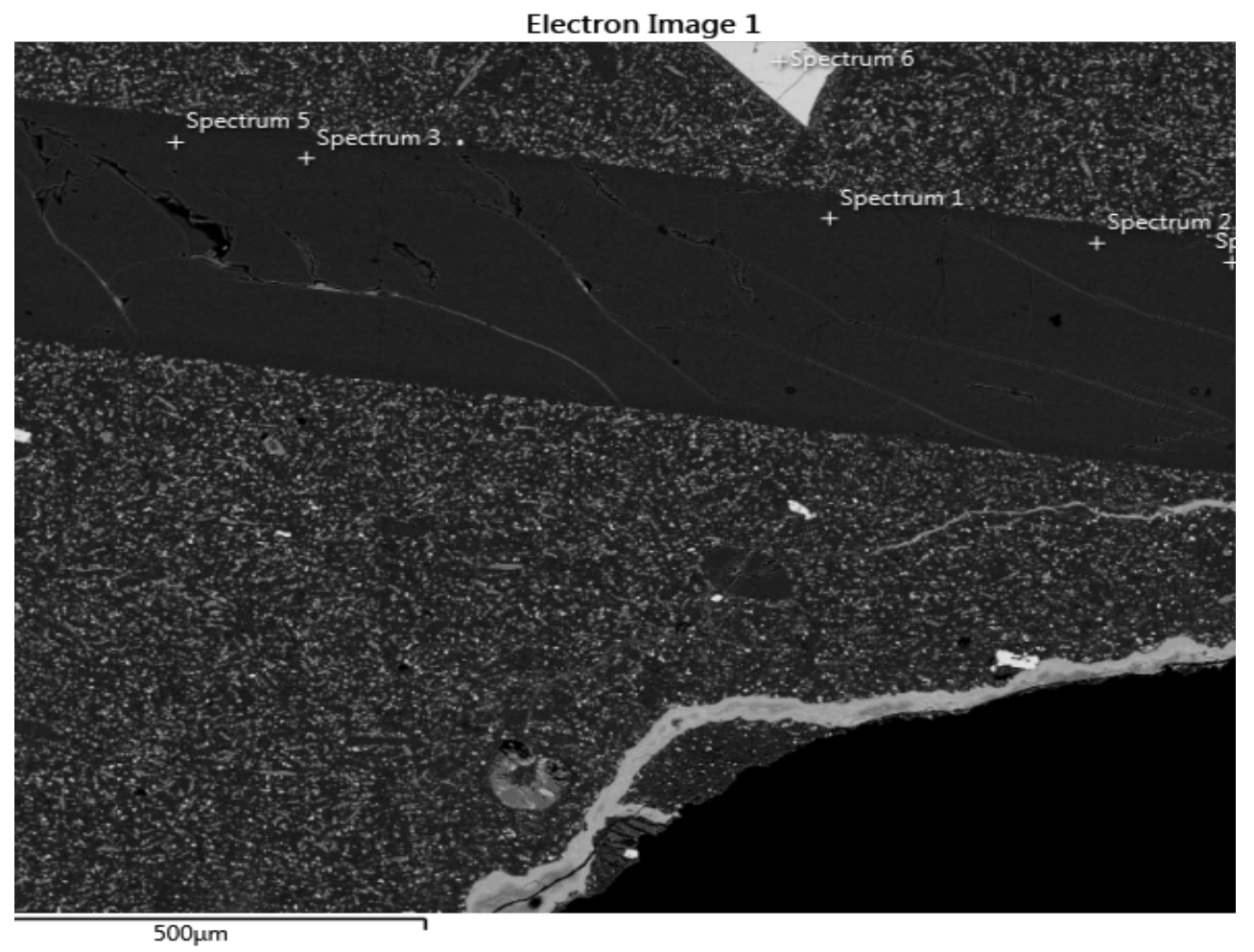

Figure B-14. Electron images of site 1 of sample MAC-17-16.

Electron Image 2

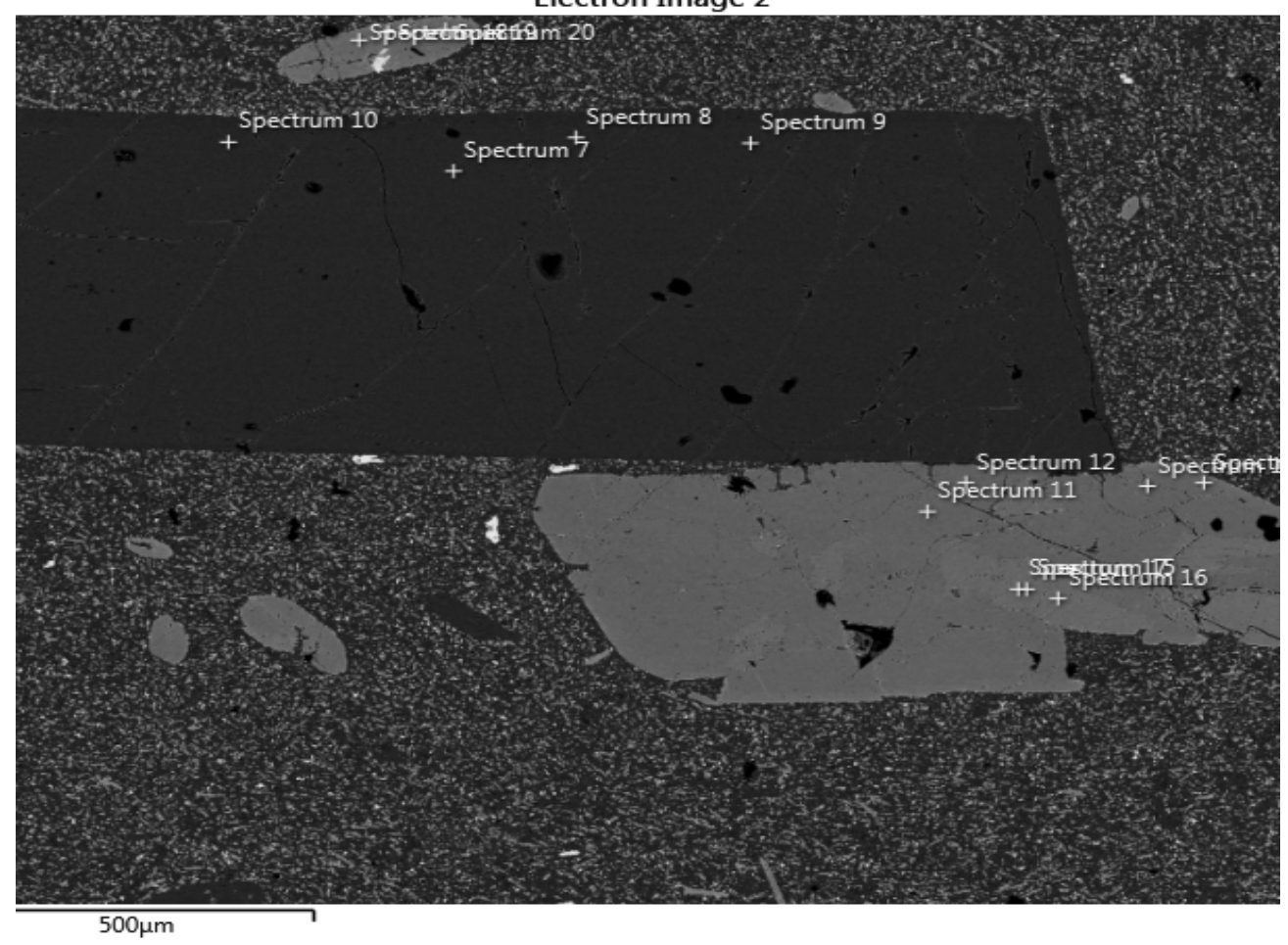

Figure B-15. Electron images of site 2 of sample MAC-17-16. 
Electron Image 3

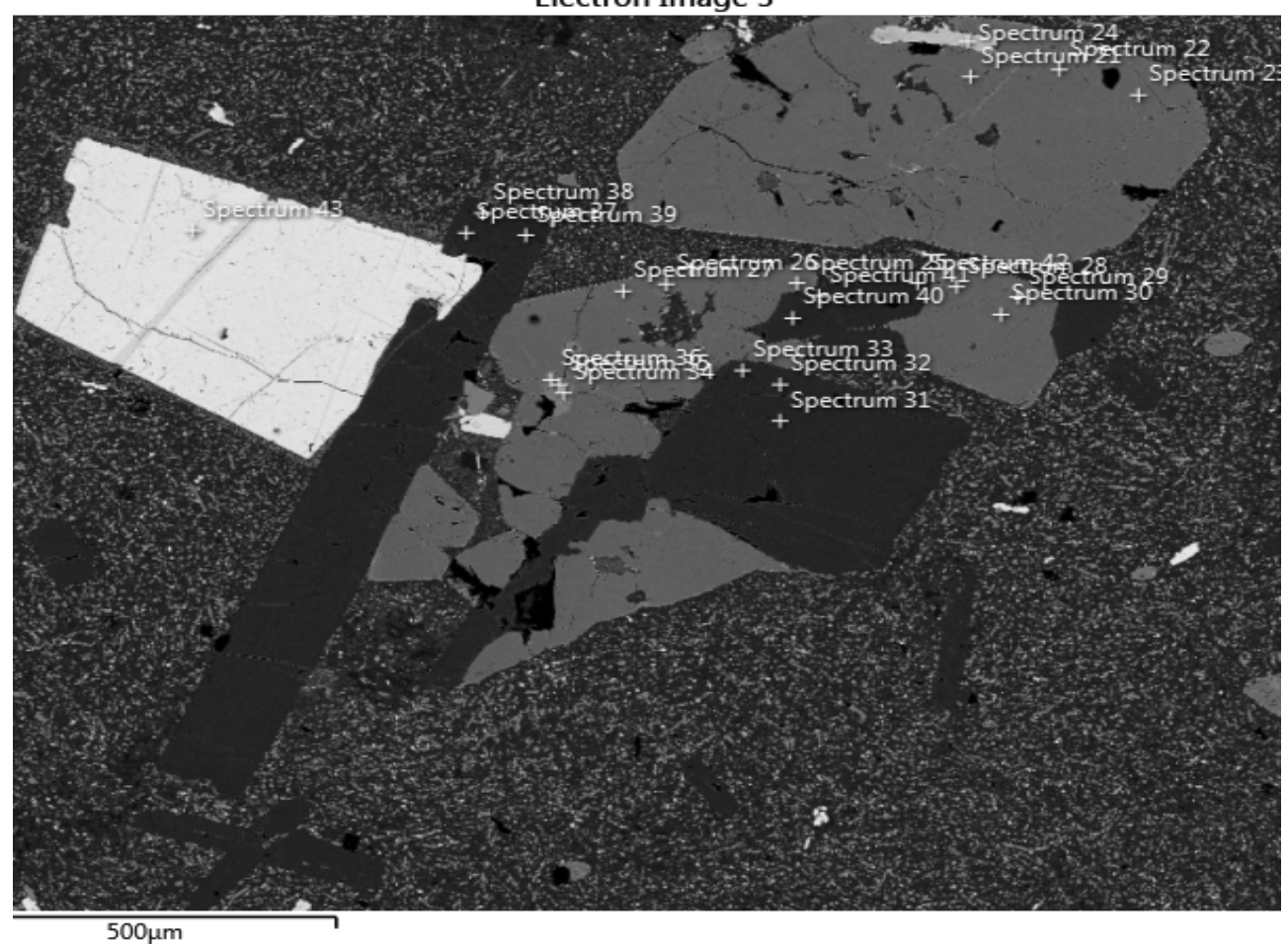

Figure B-16. Electron images of site 3 of sample MAC-17-16.

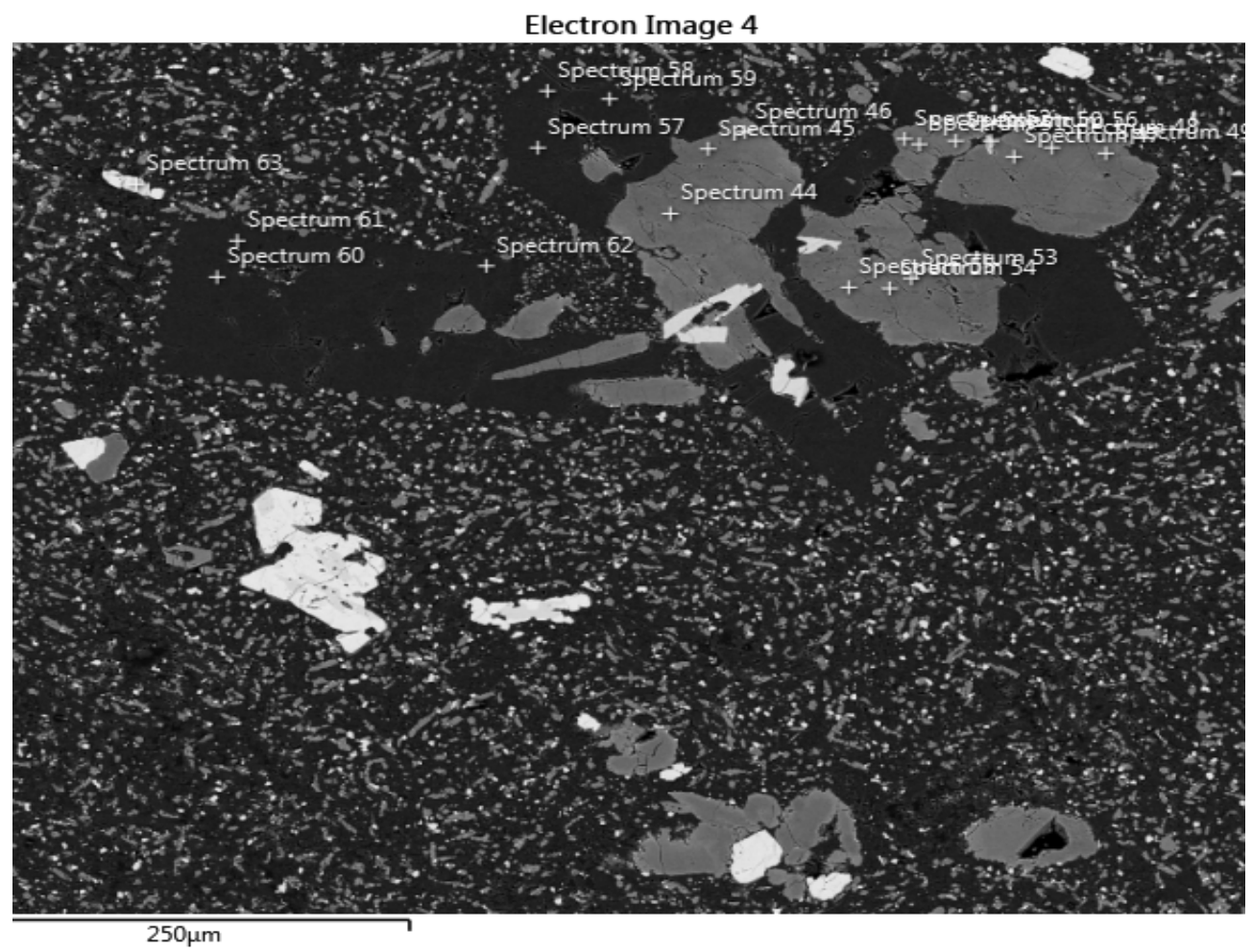

Figure B-17. Electron images of site 4 of sample MAC-17-16. 
Table B-3. Selected EDS spectra for sites 1-4 of MAC-17-16.

\begin{tabular}{|c|c|c|c|c|c|c|c|c|c|c|c|c|}
\hline MAC-17-16 & $\mathrm{SiO}_{2}$ & $\mathrm{TiO}_{2}$ & $\mathrm{Al}_{2} \mathrm{O}_{3}$ & $\mathrm{FeO}$ & $\mathrm{MnO}$ & $\mathrm{MgO}$ & $\mathrm{CaO}$ & $\mathrm{Na}_{2} \mathrm{O}$ & $\mathrm{K}_{2} \mathrm{O}$ & $\mathrm{P}_{2} \mathrm{O}_{5}$ & Total & Phase \\
\hline Spectrum 1 & 56.02 & & 27.75 & 0.62 & & & 9.92 & 5.56 & 0.34 & & 100.22 & Plagioclase \\
\hline Spectrum 4 & 55.40 & & 26.77 & 0.55 & & & 9.41 & 5.65 & 0.47 & & 98.26 & Plagioclase \\
\hline Spectrum 9 & 56.75 & & 27.33 & 0.48 & & & 9.56 & 5.64 & 0.39 & & 100.15 & Plagioclase \\
\hline Spectrum 22 & 50.82 & 0.86 & 1.19 & 17.41 & 0.54 & 13.55 & 14.90 & 0.21 & & & 99.48 & Pyroxene \\
\hline Spectrum 23 & 50.38 & 0.73 & 1.39 & 16.43 & 0.54 & 13.06 & 15.55 & 0.24 & & & 98.30 & Pyroxene \\
\hline Spectrum 27 & 50.80 & 0.74 & 1.30 & 16.78 & 0.54 & 13.39 & 15.47 & 0.24 & & & 99.27 & Pyroxene \\
\hline Spectrum 28 & 50.51 & 0.88 & 1.34 & 15.98 & 0.46 & 12.93 & 16.80 & 0.20 & & & 99.11 & Pyroxene \\
\hline Spectrum 33 & 56.00 & & 26.87 & 0.64 & & & 9.05 & 5.72 & 0.40 & & 98.68 & Plagioclase \\
\hline Spectrum 34 & 0.25 & & 0.10 & 0.57 & & 0.21 & 53.41 & & & 41.34 & 95.88 & Apatite \\
\hline Spectrum 35 & 0.32 & & & 0.66 & & 0.21 & 53.40 & & & 41.14 & 95.73 & Apatite \\
\hline Spectrum 36 & 0.27 & & 0.10 & 0.83 & & 0.19 & 53.33 & & & 41.58 & 96.30 & Apatite \\
\hline Spectrum 38 & 57.95 & & 26.58 & 0.69 & & & 8.39 & 6.11 & 0.46 & & 100.19 & Plagioclase \\
\hline Spectrum 42 & 55.84 & & 26.87 & 0.71 & & & 9.41 & 5.65 & 0.49 & & 98.97 & Plagioclase \\
\hline Spectrum 46 & 50.39 & 0.62 & 1.02 & 20.78 & 0.68 & 13.35 & 12.07 & & & & 98.91 & Pyroxene \\
\hline Spectrum 49 & 50.60 & 0.62 & 0.74 & 23.99 & 0.84 & 14.78 & 7.20 & 0.13 & & & 98.89 & Pyroxene \\
\hline Spectrum 51 & 50.12 & 0.43 & 0.60 & 26.44 & 0.71 & 14.87 & 4.75 & & & & 97.91 & Pyroxene \\
\hline Spectrum 53 & 49.09 & 0.85 & 1.32 & 21.51 & 0.62 & 13.31 & 10.51 & & & & 97.20 & Pyroxene \\
\hline Spectrum 56 & 0.28 & 49.48 & 0.18 & 45.77 & 1.04 & 0.27 & 0.27 & & & & 97.29 & FeTi Oxide \\
\hline Spectrum 58 & 56.90 & & 26.54 & 0.68 & & & 8.96 & 5.97 & 0.55 & & 99.61 & Plagioclase \\
\hline Spectrum 62 & 56.43 & & 26.62 & 0.67 & & & 8.61 & 5.86 & 0.49 & & 98.68 & Plagioclase \\
\hline
\end{tabular}


Electron Image 2

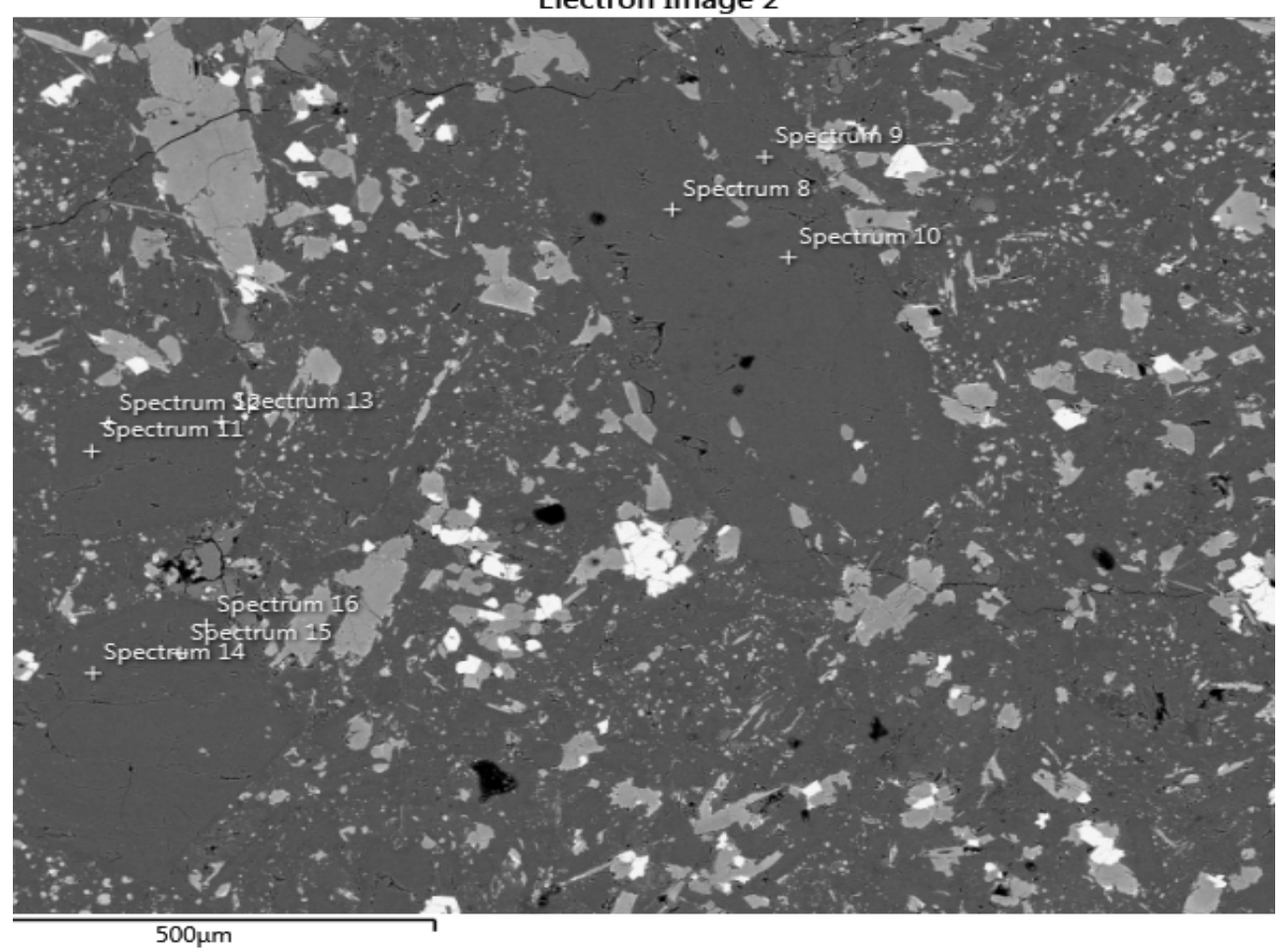

Figure B-18. Electron images of site 1 of sample MAC-17-18.

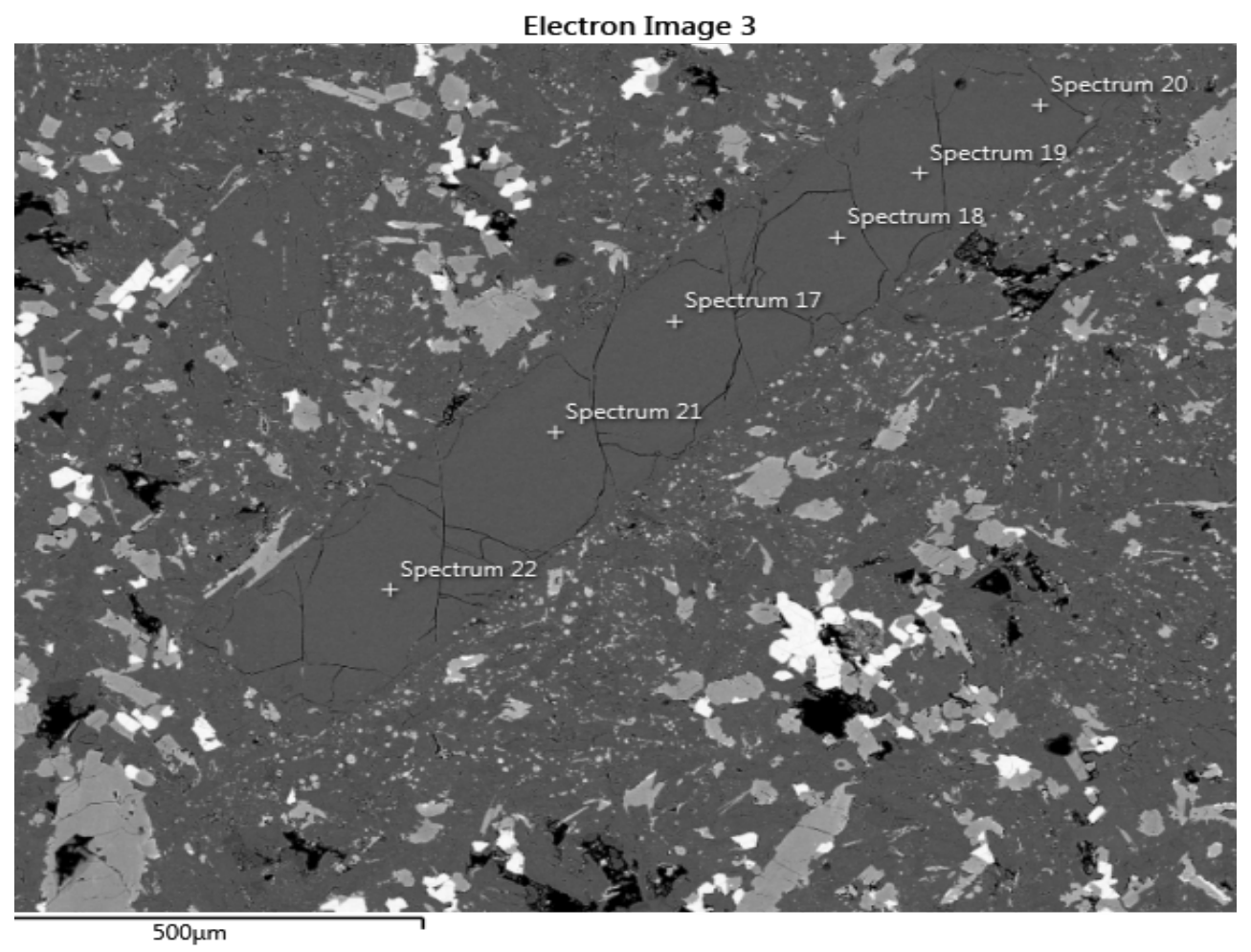

Figure B-19. Electron images of site 2 of sample MAC-17-18. 
Electron Image 4

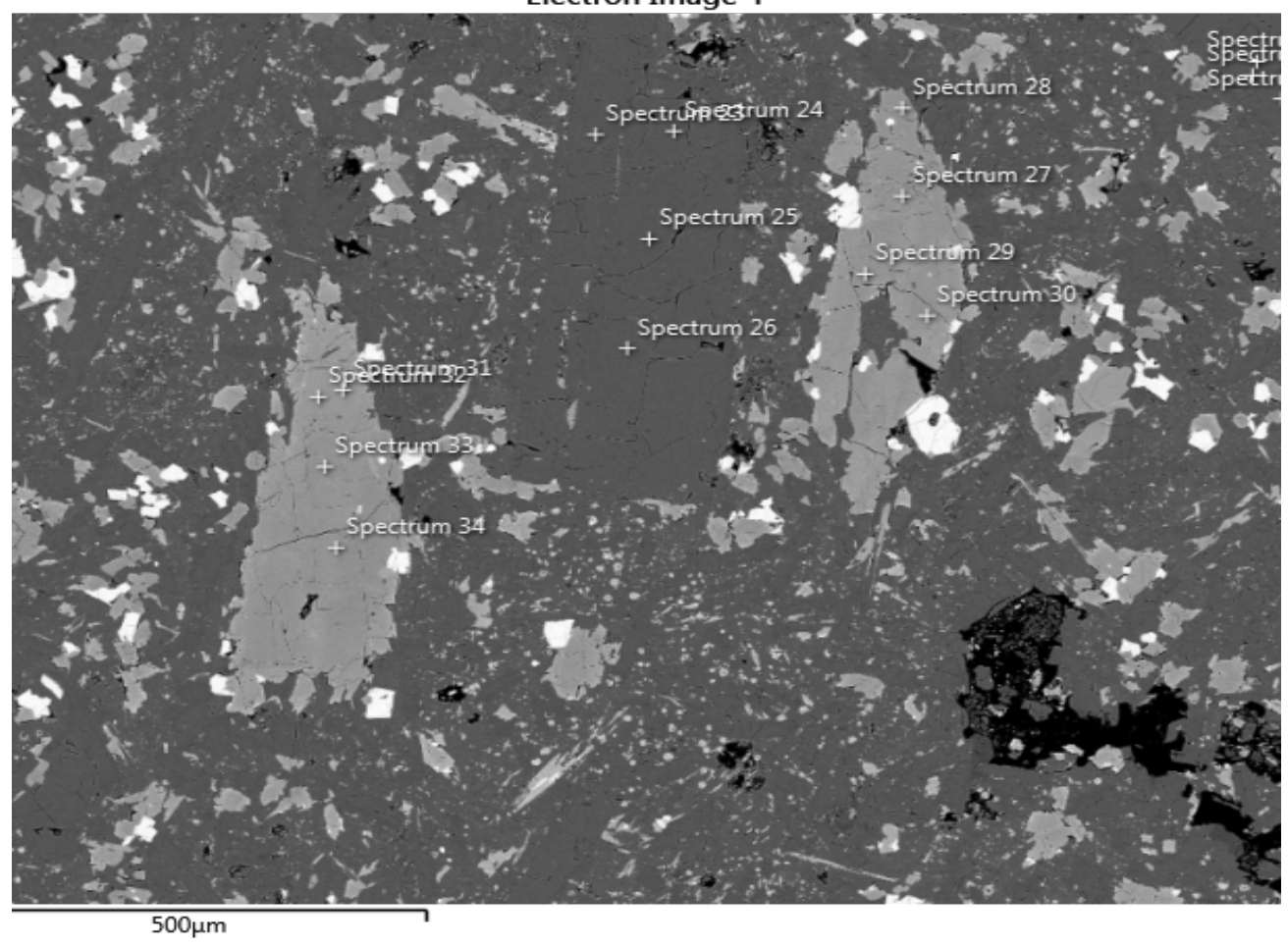

Figure B-20. Electron images of site 3 of sample MAC-17-18.

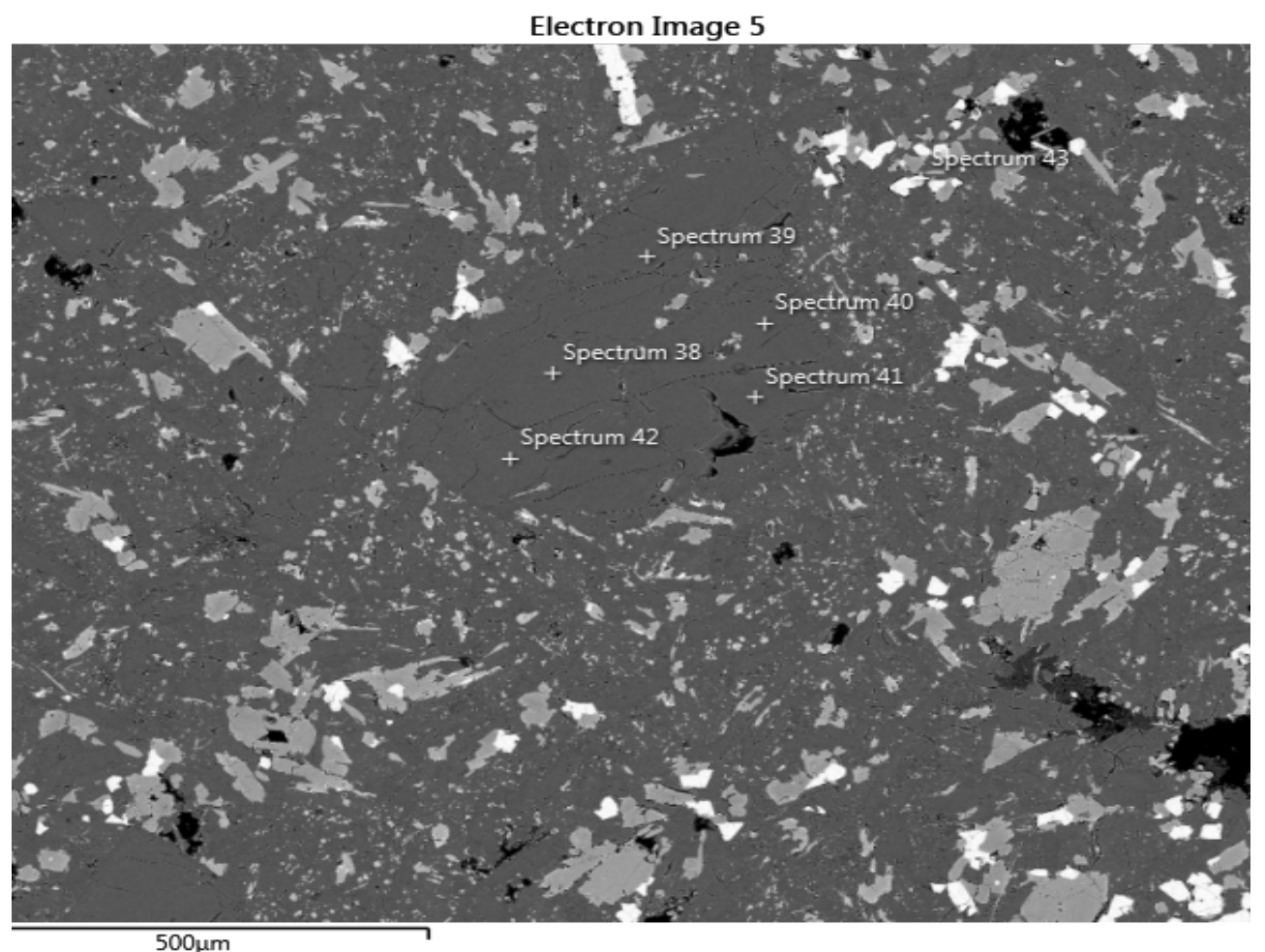

Figure B-21. Electron images of site 4 of sample MAC-17-18. 
Electron Image 6

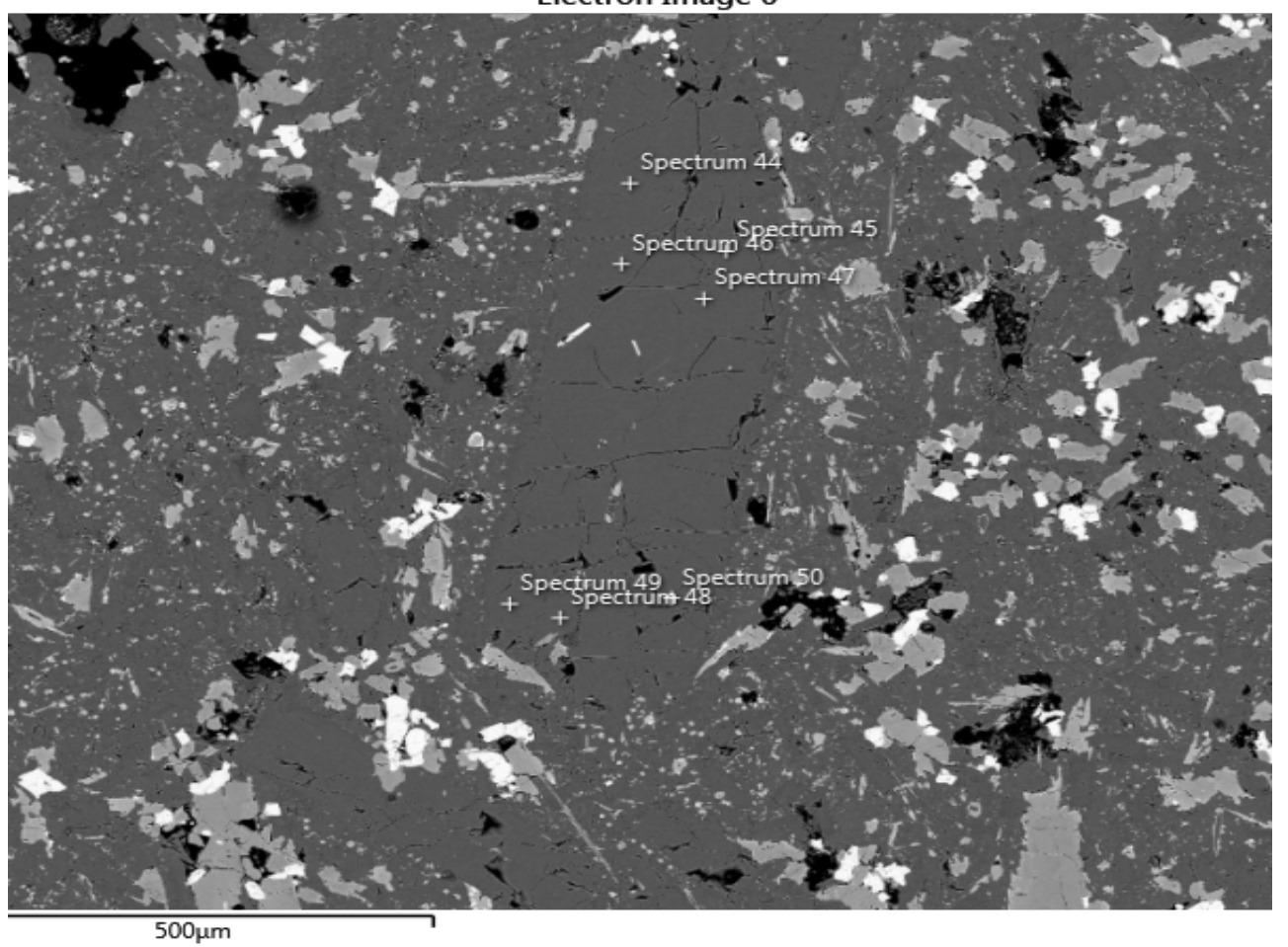

Figure B-22. Electron images of site 5 of sample MAC-17-18.

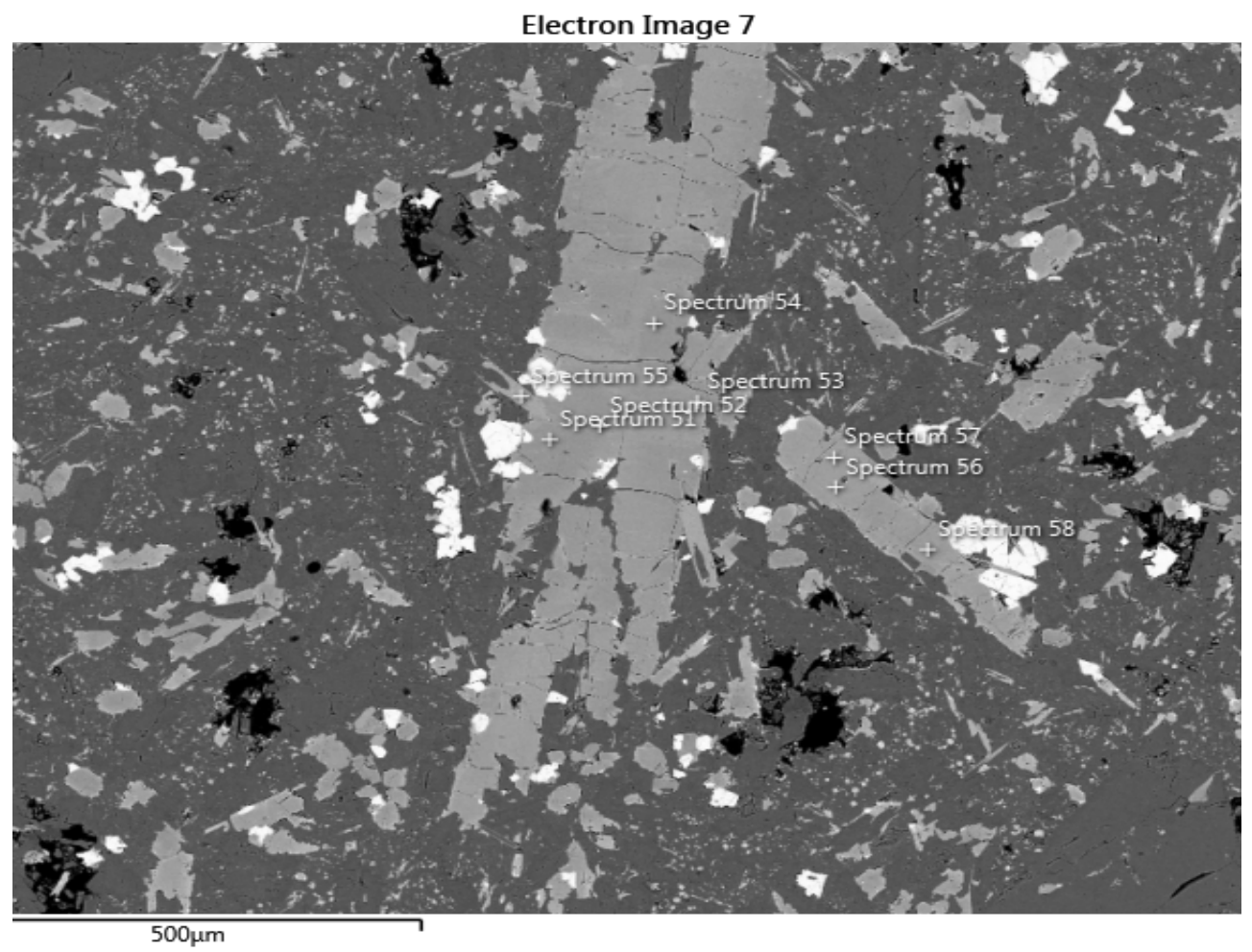

Figure B-23. Electron images of site 6 of sample MAC-17-18. 


\section{Electron Image 8}

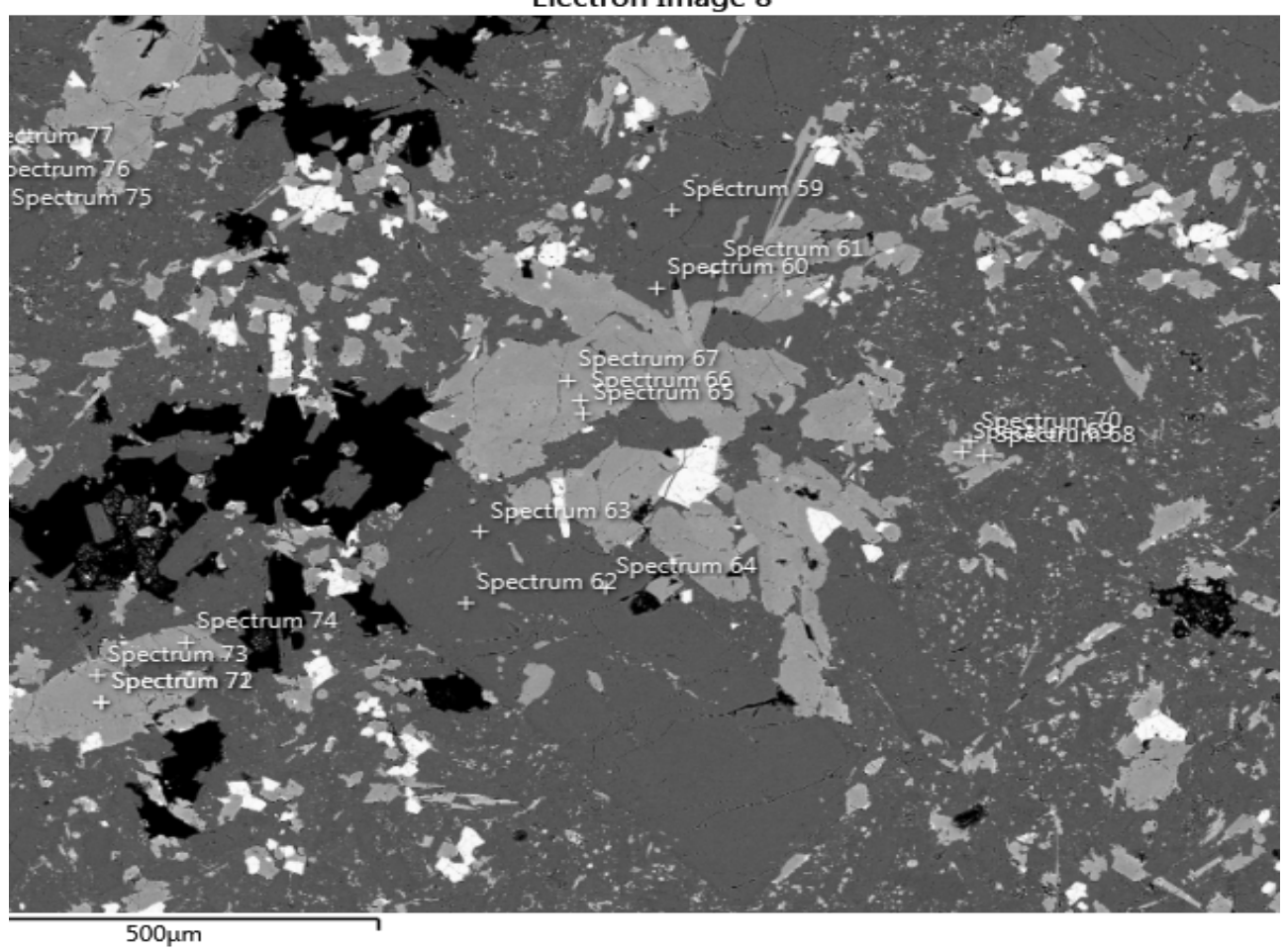

Figure B-24. Electron images of site 7 of sample MAC-17-18.

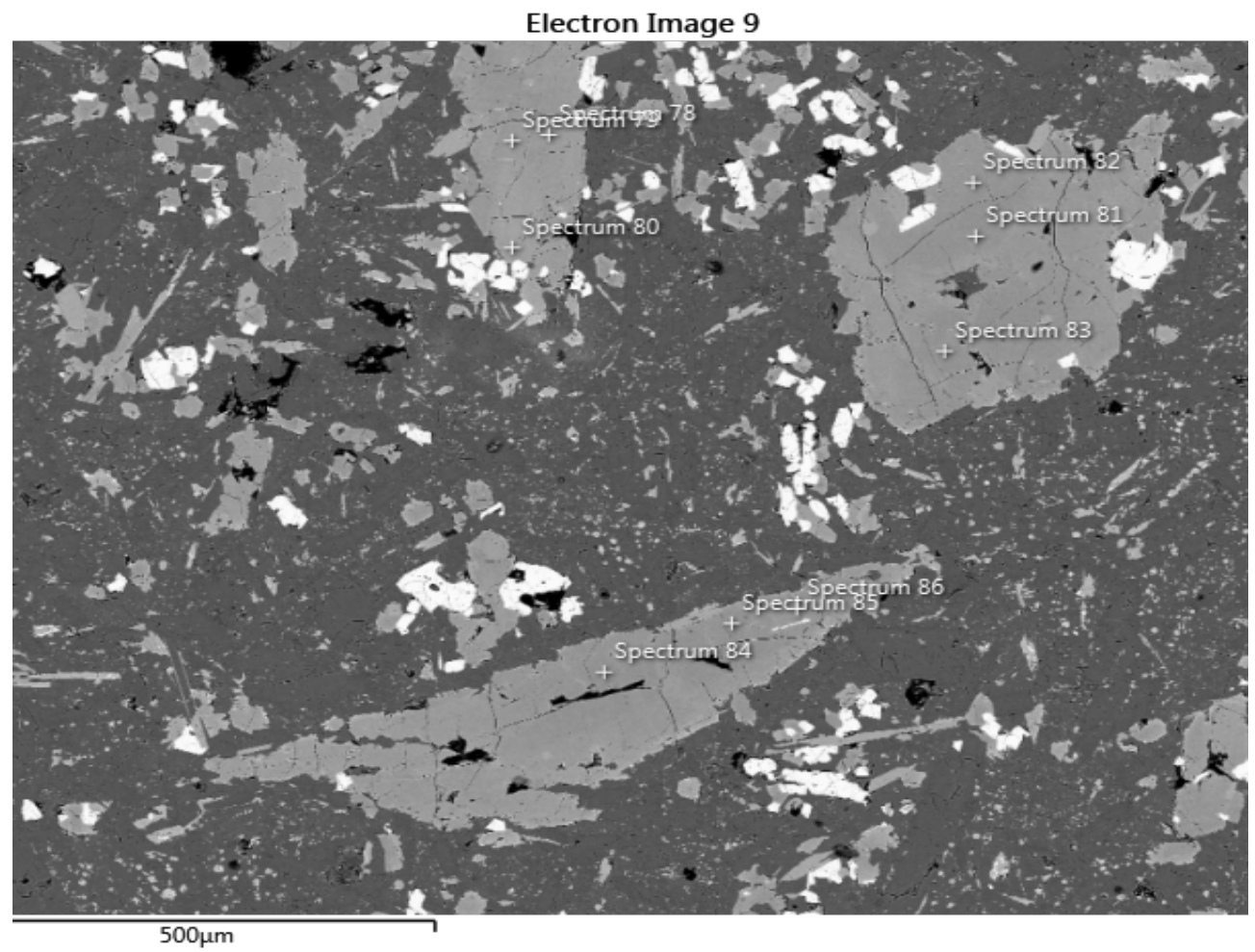

Figure B-25. Electron images of site 8 of sample MAC-17-18. 


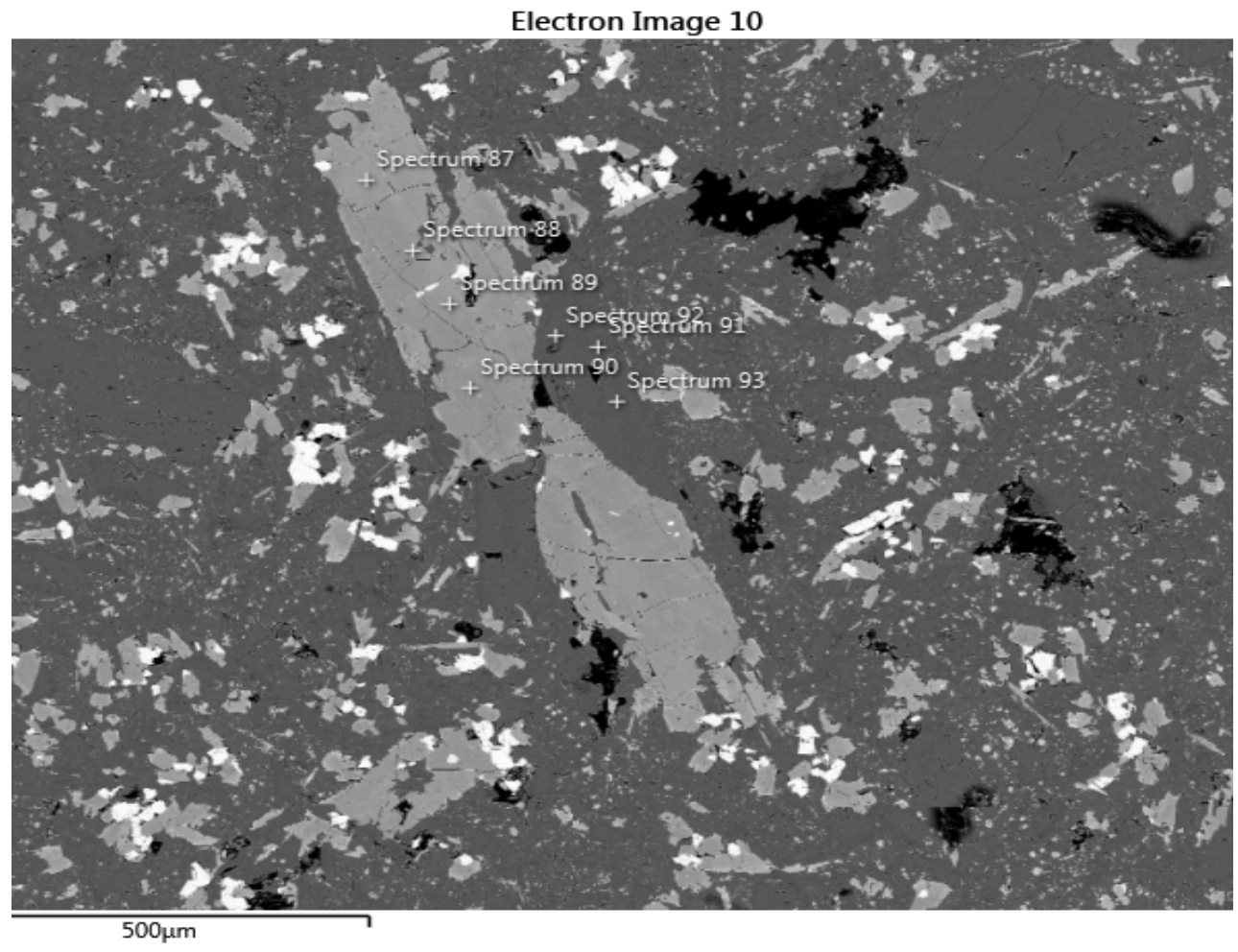

Figure B-26. Electron images of site 9 of sample MAC-17-18.

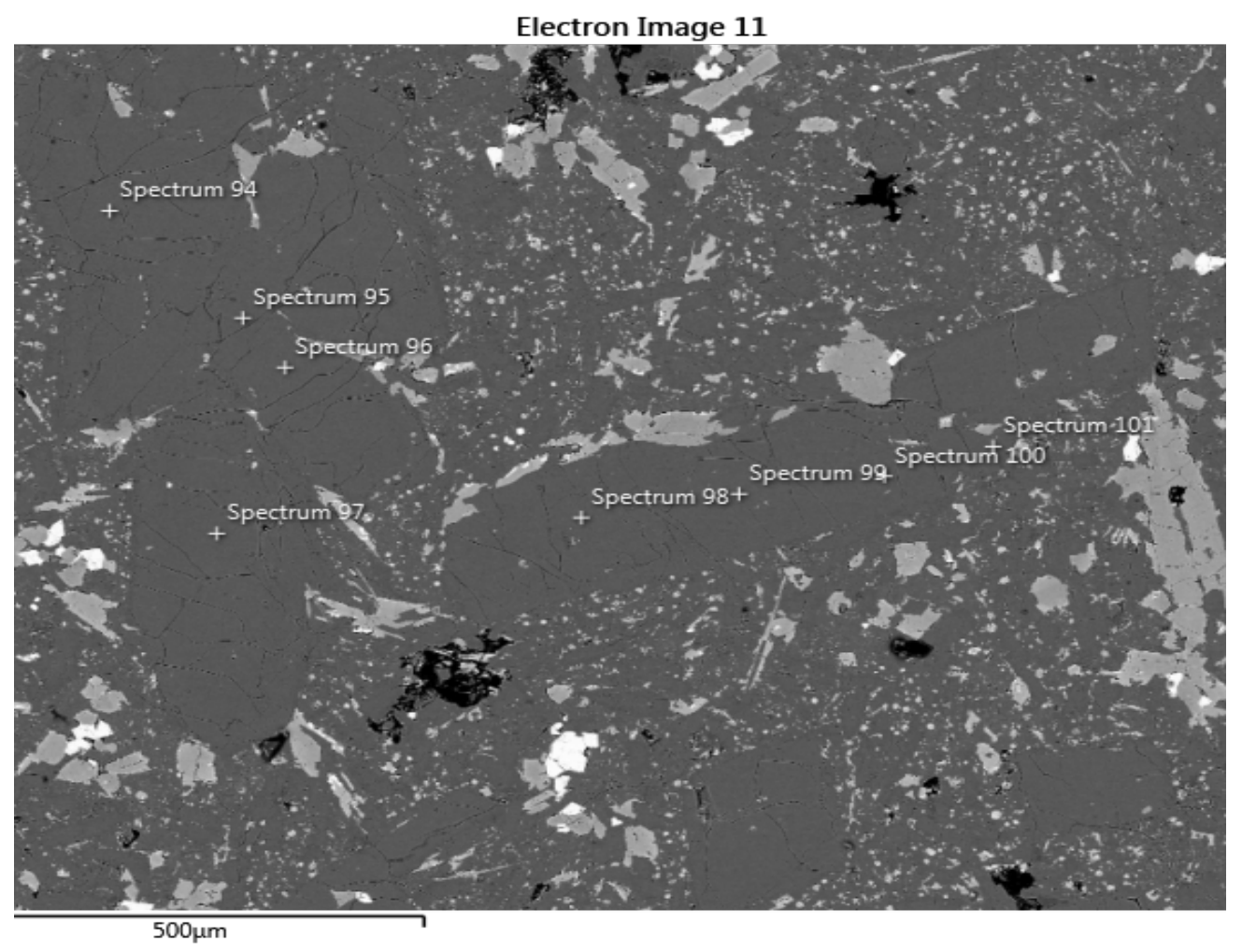

Figure B-27. Electron images of site 10 of sample MAC-17-18. 


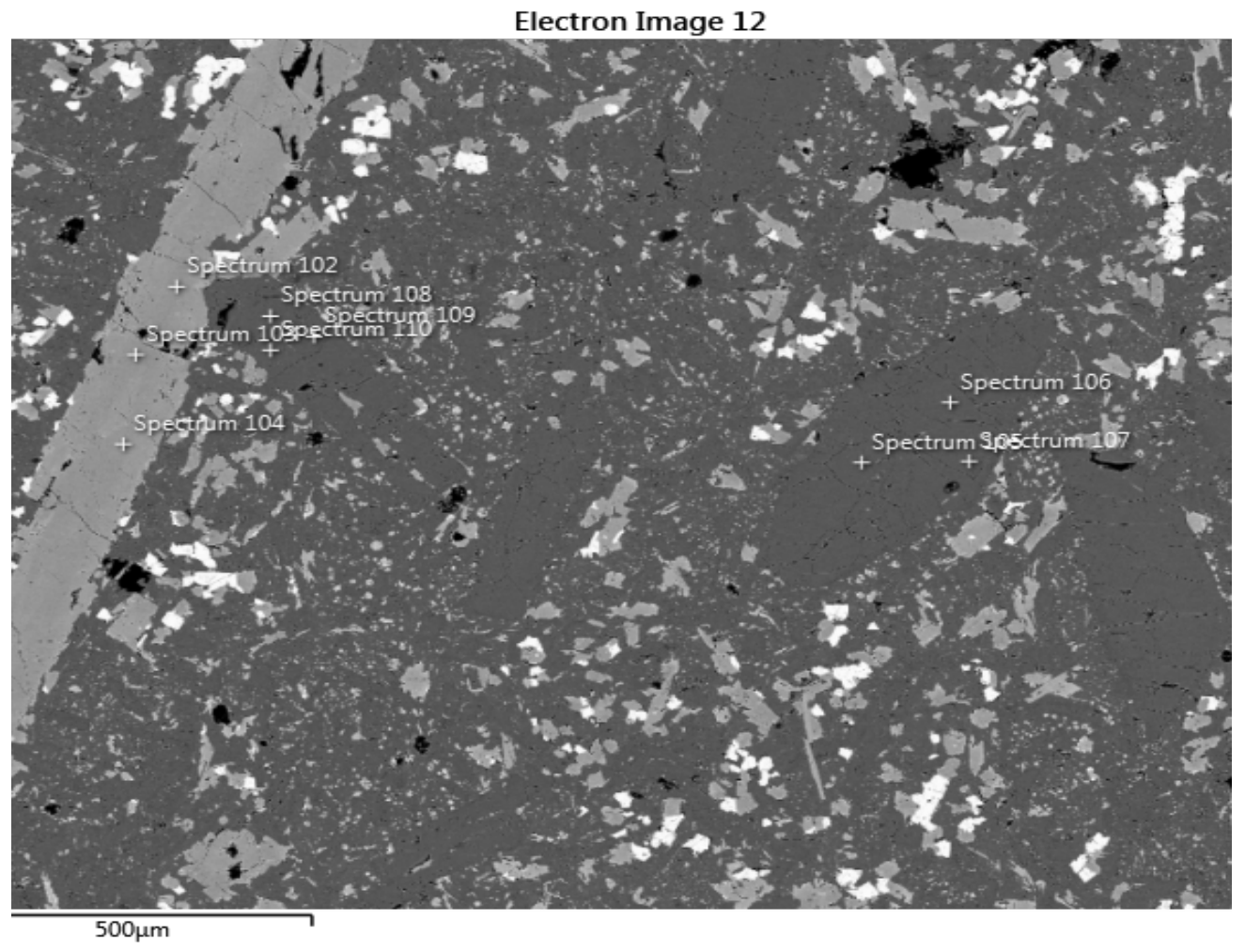

Figure B-28. Electron images of site 11 of sample MAC-17-18.

Table B-4. Selected EDS spectra for sites 1-11 of MAC-17-18.

\begin{tabular}{lcccccccccccc}
\hline \hline MAC-17-18 & $\mathrm{SiO}_{2}$ & $\mathrm{TiO}_{2}$ & $\mathrm{Al}_{2} \mathrm{O}_{3}$ & $\mathrm{FeO}$ & $\mathrm{MnO}$ & $\mathrm{MgO}$ & $\mathrm{CaO}$ & $\mathrm{Na}_{2} \mathrm{O}$ & $\mathrm{K}_{2} \mathrm{O}$ & $\mathrm{P}_{2} \mathrm{O}_{5}$ & Total & Phase \\
\hline Spectrum 14 & 57.94 & & 26.74 & & & & 8.70 & 6.06 & 0.48 & & 99.92 & Plagioclase \\
Spectrum 15 & 58.40 & & 26.18 & 0.61 & & & 8.52 & 6.19 & 0.57 & & 100.48 & Plagioclase \\
Spectrum 22 & 56.49 & & 27.41 & 0.53 & & & 9.95 & 5.72 & 0.37 & 100.47 & Plagioclase \\
Spectrum 30 & 50.72 & 0.93 & 1.79 & 19.88 & 0.46 & 12.89 & 13.48 & 0.29 & & & 100.46 & Pyroxene \\
Spectrum 32 & 50.38 & 0.62 & 1.22 & 24.36 & 0.61 & 13.67 & 8.83 & 0.17 & & 99.85 & Pyroxene \\
Spectrum 43 & 0.37 & 25.12 & 1.87 & 71.25 & 0.79 & & 0.19 & & & & 99.60 & altered \\
Spectrum 50 & 57.58 & & 26.46 & 0.49 & & & 8.69 & 6.15 & 0.51 & & 99.89 & Plagioclase \\
Spectrum 55 & 2.09 & 0.44 & 0.47 & 1.90 & & 0.13 & 52.69 & 0.20 & 0.16 & 40.45 & 98.54 & Apatite \\
Spectrum 58 & 50.35 & 0.84 & 1.20 & 22.42 & 0.83 & 13.00 & 11.26 & 0.17 & & & 100.07 & Pyroxene \\
Spectrum 62 & 56.58 & & 26.77 & 0.49 & & & 9.31 & 5.66 & 0.45 & & 99.26 & Plagioclase \\
Spectrum 64 & 56.97 & & 26.23 & 0.57 & & & 8.74 & 5.99 & 0.51 & & 99.01 & Plagioclase \\
Spectrum 68 & 50.98 & 0.58 & 0.67 & 26.94 & 0.94 & 14.65 & 5.69 & & & 100.45 & Pyroxene \\
Spectrum 73 & 49.10 & 0.81 & 1.42 & 20.98 & 0.61 & 12.46 & 12.20 & 0.28 & & & 97.87 & Pyroxene \\
Spectrum 74 & 49.89 & 0.42 & 0.52 & 27.30 & 0.91 & 14.77 & 4.94 & & & & 98.76 & Pyroxene \\
Spectrum 86 & 49.65 & 0.99 & 1.63 & 18.41 & 0.57 & 12.03 & 15.49 & 0.27 & & & 99.04 & Pyroxene \\
Spectrum 97 & 58.07 & & 26.65 & 0.44 & & & 8.97 & 5.87 & 0.45 & & 100.46 & Plagioclase \\
Spectrum 98 & 56.60 & & 26.81 & 1.72 & & 0.41 & 8.86 & 5.65 & 0.46 & & 100.50 & Plagioclase \\
Spectrum 101 & 58.60 & & 25.46 & 1.17 & & & 8.09 & 6.19 & 0.61 & & 100.11 & Plagioclase \\
\hline \hline
\end{tabular}


Electron Image 2

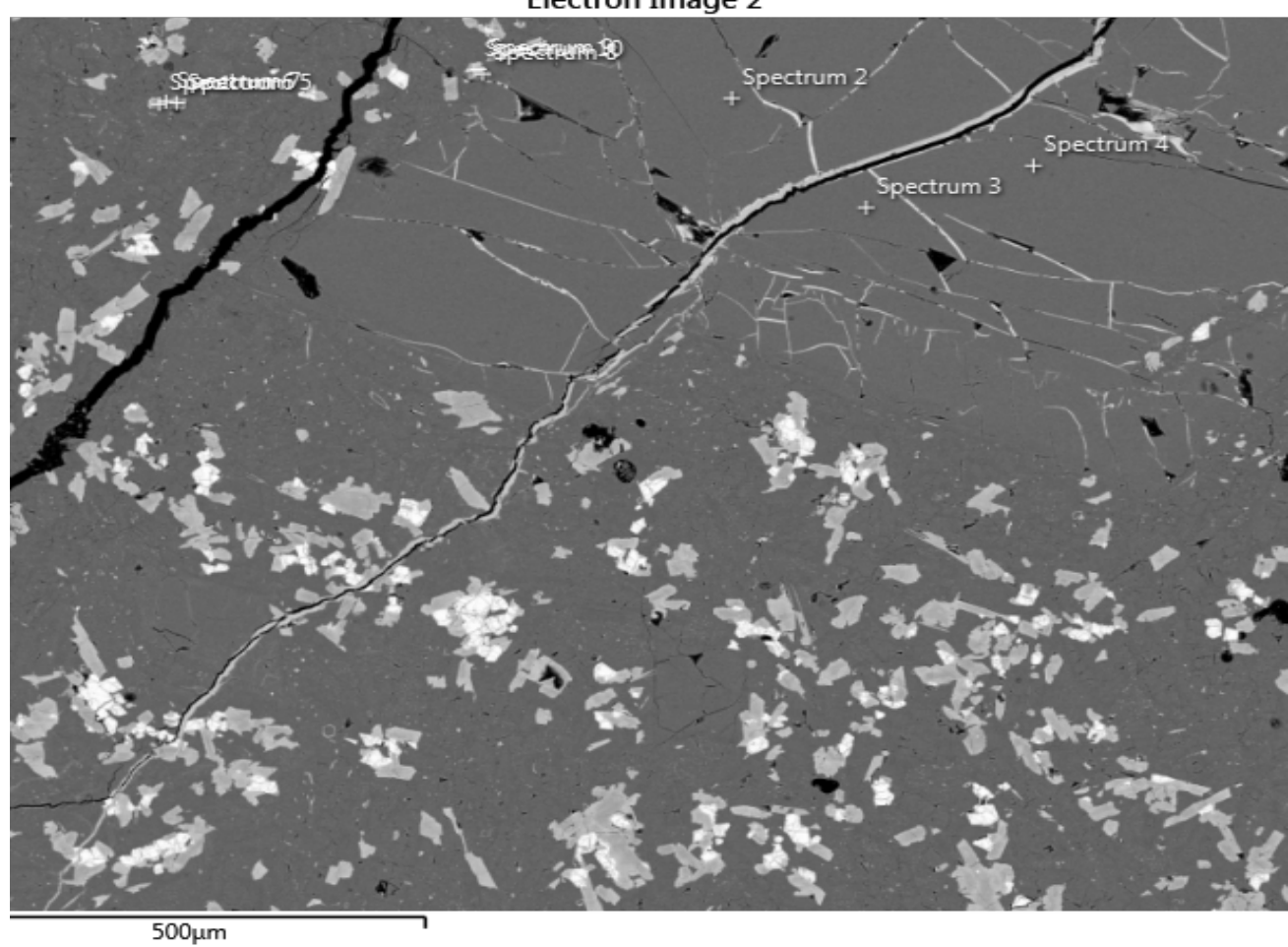

Figure B-28. Electron images of site 1 of sample MAC-17-29

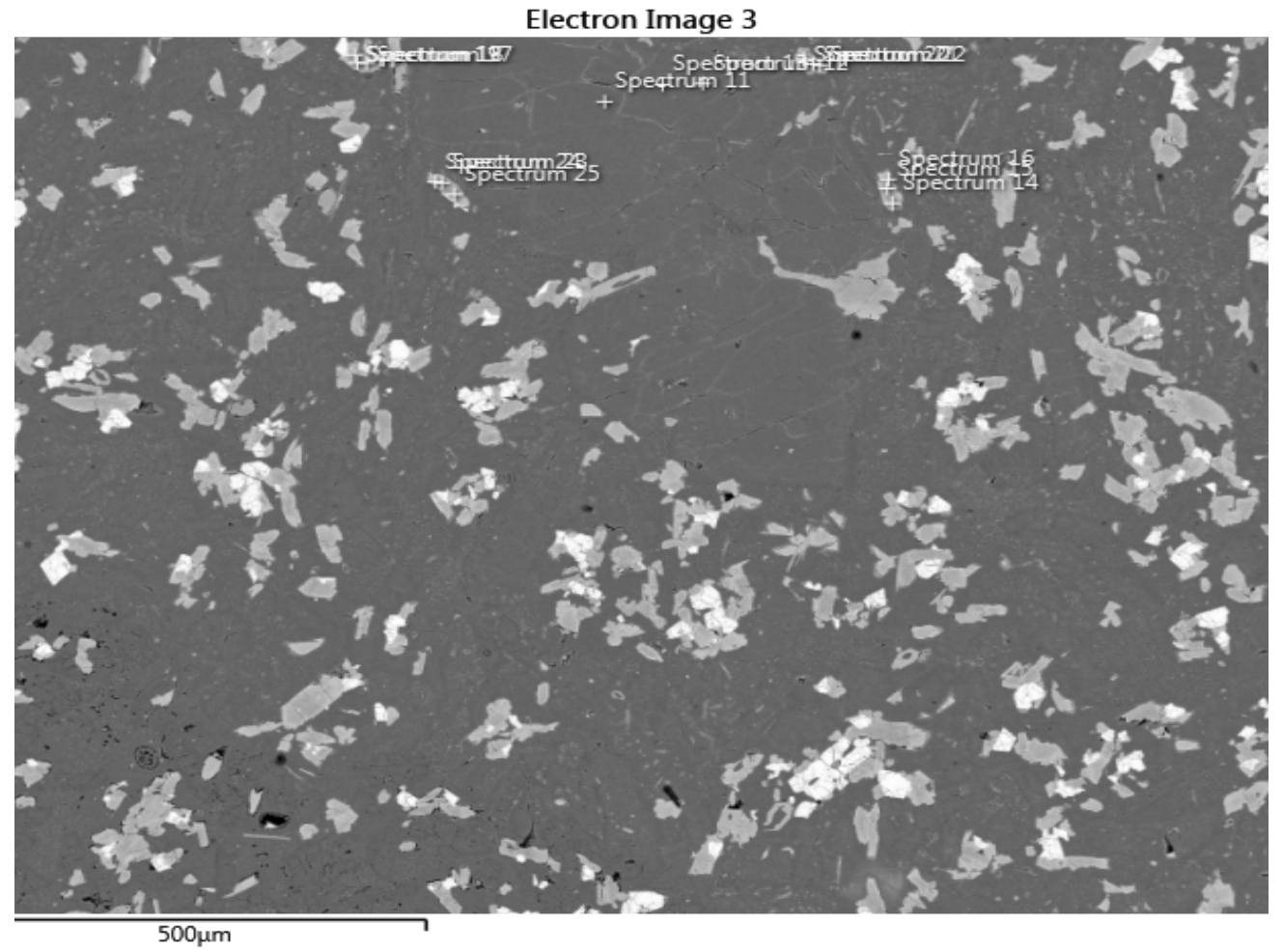

Figure B-29. Electron images of site 2 of sample MAC-17-29 


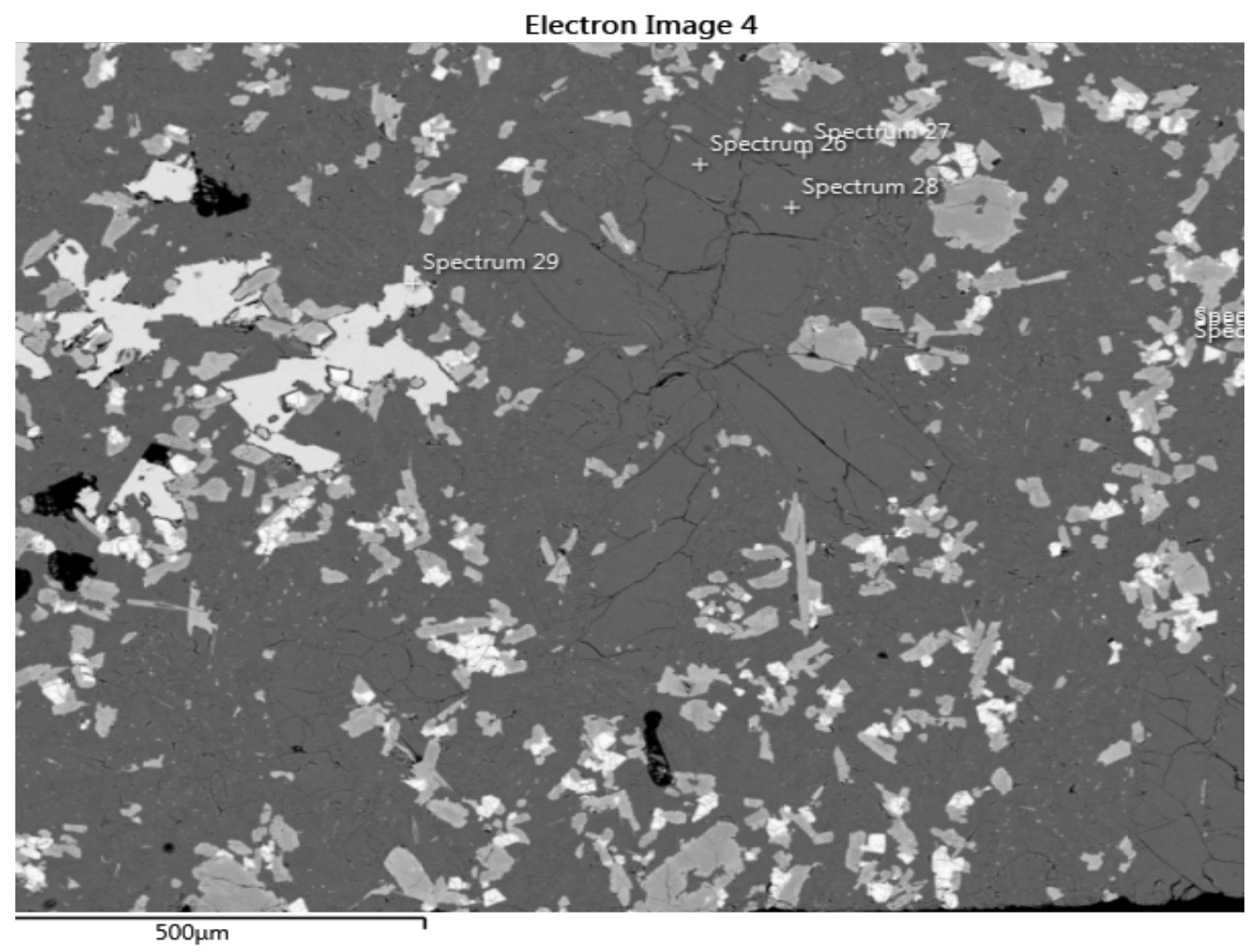

Figure B-30. Electron images of site 3 of sample MAC-17-29

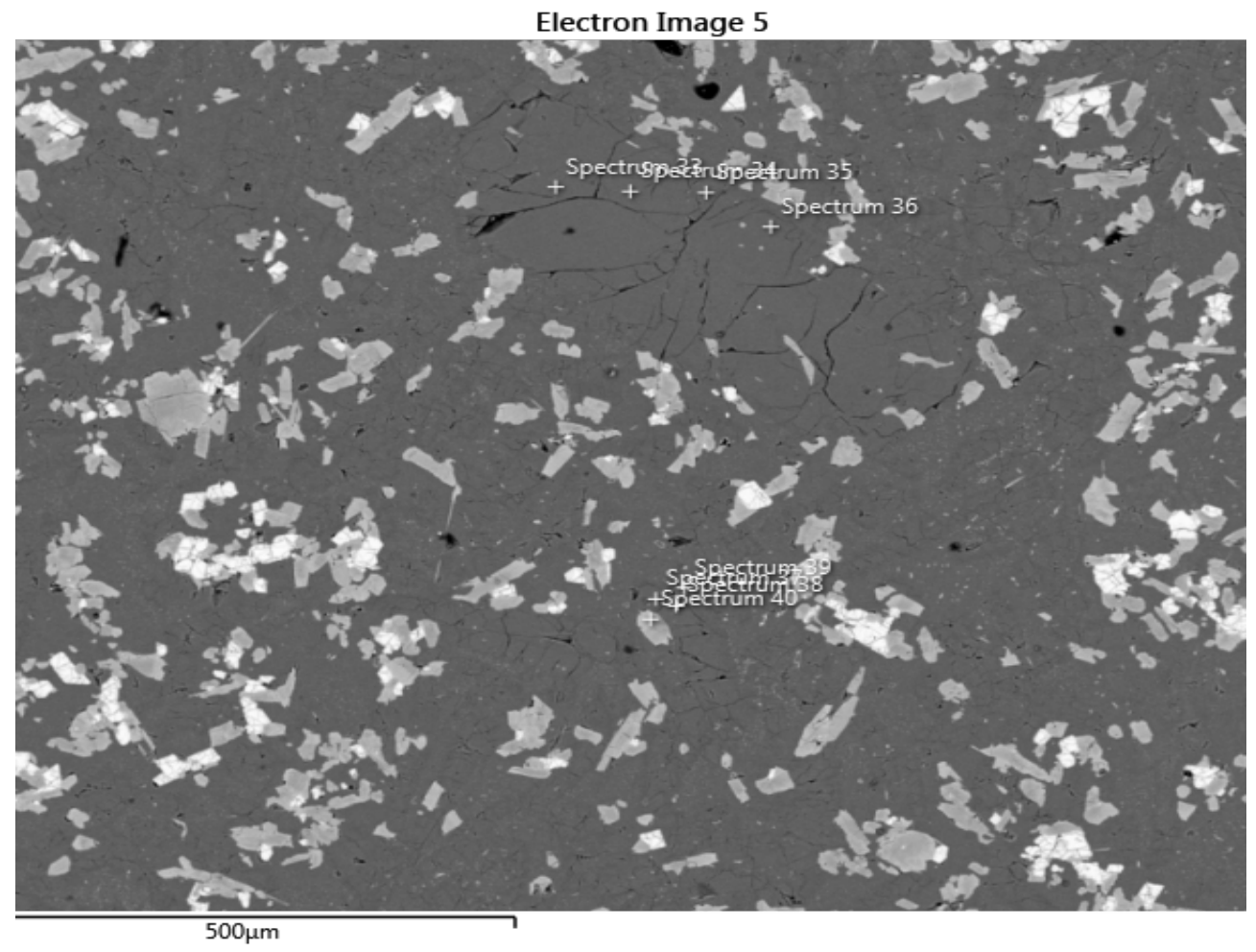

Figure B-31. Electron images of site 4 of sample MAC-17-29 


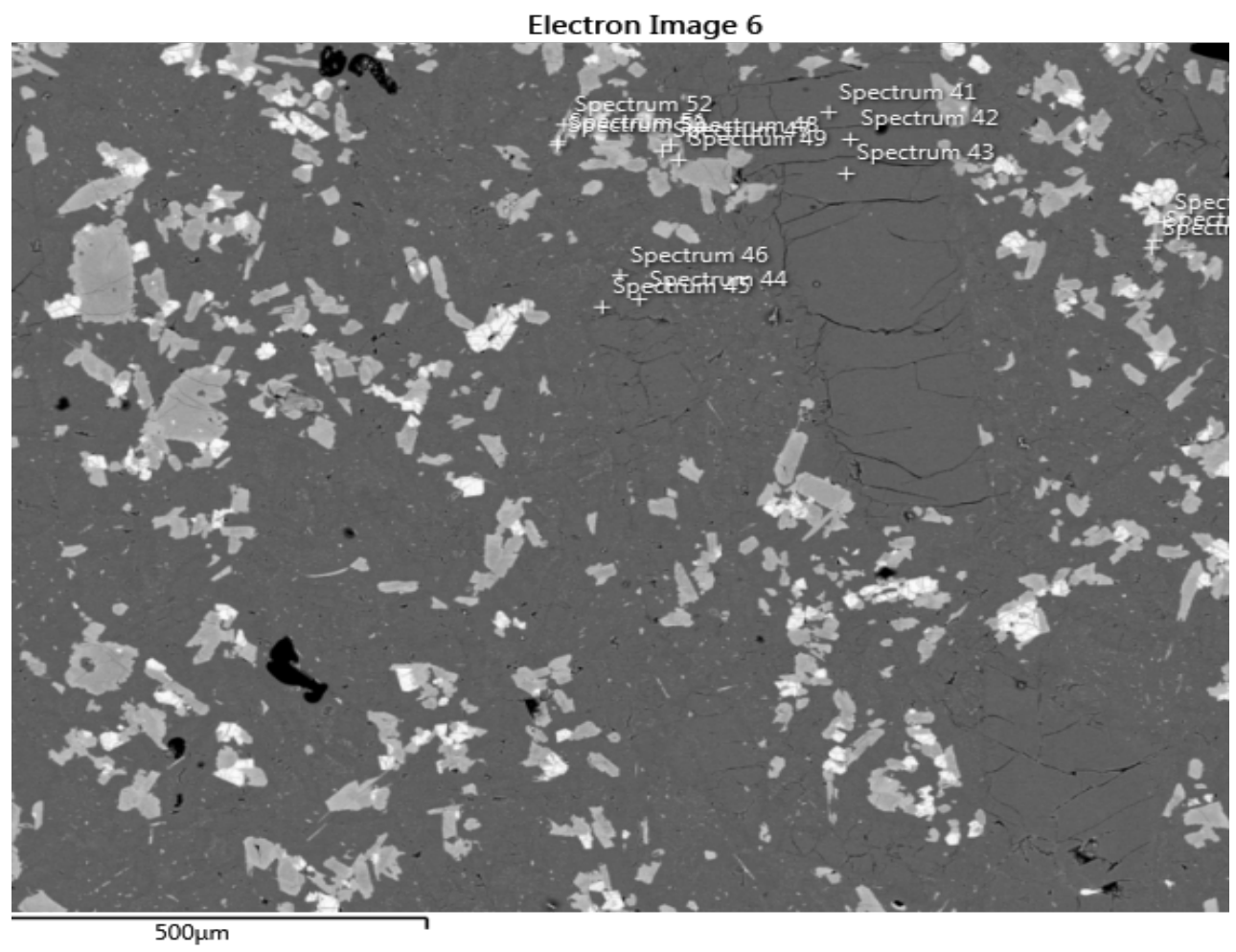

Figure B-32. Electron images of site 5 of sample MAC-17-29

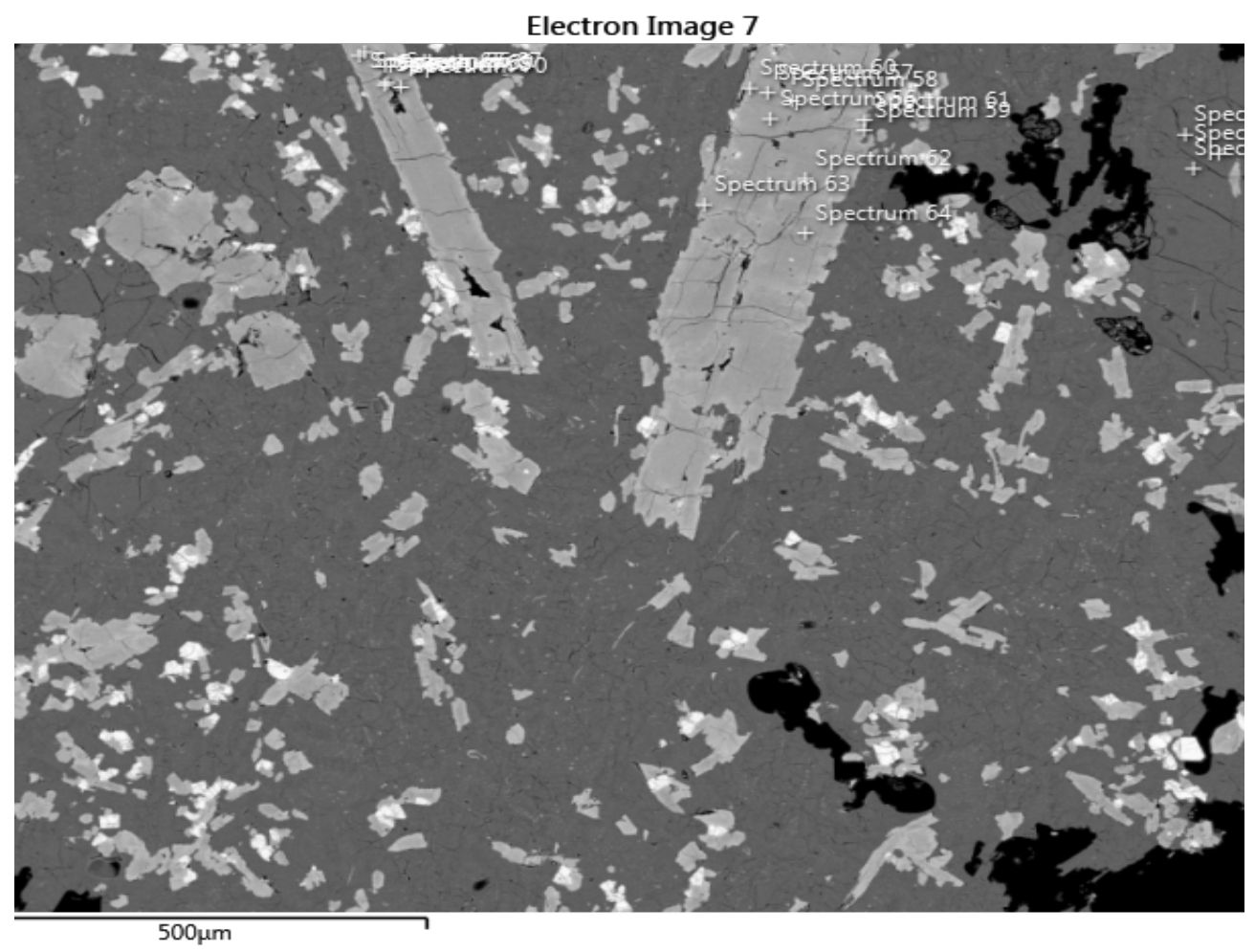

Figure B-33. Electron images of site 6 of sample MAC-17-29 
Table B-5. Selected EDS spectra for sites 1-6 of MAC-17-29.

\begin{tabular}{lcccccccccccc}
\hline \hline MAC-17-29 & $\mathrm{SiO}_{2}$ & $\mathrm{TiO}_{2}$ & $\mathrm{Al}_{2} \mathrm{O}_{3}$ & $\mathrm{FeO}$ & $\mathrm{MnO}$ & $\mathrm{MgO}$ & $\mathrm{CaO}$ & $\mathrm{Na}_{2} \mathrm{O}$ & $\mathrm{K}_{2} \mathrm{O}$ & $\mathrm{P}_{2} \mathrm{O}_{5}$ & Total & Phase \\
\hline Spectrum 3 & 56.08 & & 27.60 & 0.62 & & & 10.16 & 5.56 & 0.39 & 100.41 & Plagioclase \\
Spectrum 4 & 56.06 & & 27.52 & 0.63 & & & 10.06 & 5.46 & 0.40 & 100.14 & Plagioclase \\
Spectrum 6 & 49.32 & 0.60 & 0.98 & 25.58 & 0.74 & 9.60 & 11.96 & 0.20 & & 98.99 & Pyroxene \\
Spectrum 14 & 49.98 & 0.52 & 0.81 & 27.01 & 0.95 & 11.66 & 8.93 & 0.10 & & 99.95 & Pyroxene \\
Spectrum 20 & 49.07 & 0.57 & 1.29 & 31.95 & 1.09 & 7.90 & 8.20 & 0.12 & & 100.18 & Pyroxene \\
Spectrum 25 & 50.21 & 0.49 & 0.63 & 30.27 & 0.92 & 12.16 & 5.62 & & & 100.31 & Pyroxene \\
Spectrum 28 & 57.75 & & 26.73 & 0.48 & & & 8.89 & 6.05 & 0.44 & 100.33 & Plagioclase \\
Spectrum 31 & 49.97 & 0.43 & 0.67 & 26.98 & 0.76 & 14.97 & 5.24 & & & 99.02 & Pyroxene \\
Spectrum 33 & 58.05 & & 26.46 & 0.57 & & & 8.58 & 6.13 & 0.50 & 100.29 & Plagioclase \\
Spectrum 36 & 58.48 & & 25.79 & 0.53 & & & 7.70 & 6.58 & 0.51 & 99.60 & Plagioclase \\
Spectrum 40 & 48.73 & 0.47 & 0.61 & 30.85 & 0.87 & 11.03 & 5.51 & 0.13 & & 98.21 & Pyroxene \\
Spectrum 44 & 58.08 & & 26.35 & 0.51 & & & 8.30 & 6.45 & 0.56 & 100.25 & Plagioclase \\
Spectrum 46 & 58.12 & & 25.97 & 0.64 & & & 8.20 & 6.28 & 0.51 & 99.73 & Plagioclase \\
Spectrum 55 & 50.16 & 0.76 & 1.06 & 19.79 & 0.65 & 11.15 & 15.39 & 0.18 & & 99.13 & Pyroxene \\
Spectrum 59 & 52.36 & & 13.27 & 17.33 & 0.61 & 3.11 & 6.11 & 4.03 & 0.40 & 97.23 & Plagioclase? \\
Spectrum 61 & 49.35 & 0.62 & 0.69 & 32.47 & 1.01 & 10.04 & 5.96 & 0.11 & & 100.23 & Pyroxene \\
Spectrum 63 & 49.40 & 0.46 & 0.67 & 27.95 & 0.84 & 7.96 & 12.29 & 0.28 & & 99.86 & Pyroxene \\
Spectrum 73 & 57.12 & & 26.60 & 0.68 & & & 9.00 & 6.21 & 0.48 & 100.08 & Plagioclase \\
\hline \hline
\end{tabular}




\section{Appendix C: Partition Coefficients}

Table C-1. Partition coefficients used in crystallization model.

\section{Plagioclase Olivine Clinopyroxene Magnetite Ilmenite Bulk-D value}

\begin{tabular}{|c|c|c|c|c|c|c|}
\hline Sc & 0.008 & 0.235 & 1.31 & 0.73 & 1.8 & 0.556 \\
\hline $\mathrm{Ni}$ & 0.06 & 15.5 & 2.6 & 48 & 3.8 & 6.839 \\
\hline $\mathrm{Cr}$ & 0.075 & 1.18 & 4.22 & 153 & 29.85 & 17.58 \\
\hline $\mathbf{v}$ & 0.0071 & 0.03 & 3.1 & 3.435 & 12 & 2.109 \\
\hline $\mathbf{R b}$ & 0.0172 & 0.00018 & 0.011 & 0.11 & 0.034 & 0.0239 \\
\hline $\mathrm{Ba}$ & 0.21 & 0.05 & 0.0002 & 0.028 & 0.018 & 0.1121 \\
\hline Th & 0.05 & 0.0001 & 0.00026 & 0.1 & 0.00165 & 0.0337 \\
\hline $\mathbf{U}$ & 0.11 & 0.0001 & 0.0036 & 0.11 & 0.00695 & 0.0653 \\
\hline $\mathrm{Nb}$ & 0.01 & 0.01 & 0.00365 & 0.905 & 1.225 & 0.1984 \\
\hline $\mathrm{Ta}$ & 0.106 & 0.067 & 0.01195 & 1.27 & 1.73 & 0.3314 \\
\hline K & 0.192 & 0.006845 & 0.007 & 0.045 & 0.4118 & 0.1375 \\
\hline La & 0.0348 & 0.008 & 0.1047 & 0.015 & 0.098 & 0.0521 \\
\hline $\mathrm{Ce}$ & 0.0278 & 0.0076 & 0.1254 & 0.016 & 0.11 & 0.0546 \\
\hline $\mathrm{Pb}$ & 0.19 & 0.0001 & 0.216 & 2.9 & 0.117 & 0.4143 \\
\hline $\operatorname{Pr}$ & 0.02231 & 0.006611 & 0.18958 & 0.0204 & 0.1241 & 0.0682 \\
\hline Sr & 1.82 & 0.0005 & 0.06 & 0.11 & 0.0046 & 0.9160 \\
\hline $\mathbf{P}$ & 0.071 & 0.1 & 0.05 & 0.053 & 0.025 & 0.0634 \\
\hline $\mathrm{Nd}$ & 0.0179 & 0.00575 & 0.2866 & 0.026 & 0.14 & 0.0902 \\
\hline $\mathrm{Zr}$ & 0.0094 & 0.0047 & 0.131 & 0.9 & 0.3315 & 0.1460 \\
\hline Hf & 0.0092 & 0.0038 & 0.1208 & 0.14 & 0.4135 & 0.0825 \\
\hline Sm & 0.0132 & 0.0049 & 0.4774 & 0.024 & 0.15 & 0.1324 \\
\hline $\mathrm{Eu}$ & 0.0221 & 0.0052 & 0.5618 & 0.025 & 0.1 & 0.1518 \\
\hline $\mathrm{Ti}$ & 0.026 & 0.00355 & 0.325 & 6 & 0.118 & 0.6385 \\
\hline $\mathrm{Tb}$ & 0.0118 & 0.0071 & 0.6085 & 0.019 & 0.14 & 0.1608 \\
\hline Dy & 0.0112 & 0.0095 & 0.622 & 0.0180 & 0.1349 & 0.164 \\
\hline $\mathbf{Y}$ & 0.0043 & 0.0131 & 0.9 & 0.0039 & 0.0045 & 0.2112 \\
\hline $\mathrm{Yb}$ & 0.0155 & 0.0468 & 0.601 & 0.018 & 0.1225 & 0.1632 \\
\hline Lu & 0.012 & 0.053 & 0.5602 & 0.023 & 0.1005 & 0.1511 \\
\hline Gd & 0.0125 & 0.0053 & 0.595 & 0.018 & 0.14 & 0.158 \\
\hline Ho & 0.0114 & 0.0157 & 0.645 & 0.017 & 0.13 & 0.171 \\
\hline $\mathrm{Er}$ & 0.0116 & 0.0260 & 0.67 & 0.0173 & 0.1275 & 0.177 \\
\hline $\mathrm{Tm}$ & 0.0134 & 0.0348 & 0.6346 & 0.0177 & 0.1250 & 0.171 \\
\hline
\end{tabular}


Table C-2. Sources of partition coefficients used in crystallization model

\section{Sources:}

\begin{tabular}{|c|c|c|}
\hline Bougault and Hekinian 1974 & Klemme et al., 2006 & Nielson et al., 1992 \\
\hline Brunet and Chazot, 2001 & Kloeck and Palme 1988 & Norman et al., 2005 \\
\hline Dunn and Sen, 1994 & Laubier et al., 2014 & Okamoto, 1979 \\
\hline Ewart and Griffin, 1994 & Lemarchand et al. 1987 & Paster et al., 1974 \\
\hline Fujimaki et al. 1984 & Matsui et al. 1977 & Philpotts and Schnetzler, 1970 \\
\hline Green et al. 1989 & McKay et al., 1986 & Ringwood, 1970 \\
\hline Green et al. 2000 & McKenzie and O'nions, 1991 & \multirow[t]{3}{*}{ Interpolated values } \\
\hline Hart and Dunn, 1993 & Mysen, 1978 & \\
\hline Jang and Nasland, 2003 & Nielson, 1992 & \\
\hline
\end{tabular}




\section{Appendix D: Fractional (Rayleigh) Crystallization Model}

Table D-1. Major and compatible trace element bulk rock geochemistry for group 1 used in crystallization model.

\begin{tabular}{ccccccc}
\hline \hline $\begin{array}{c}\text { Major } \\
\text { Element } \\
\text { Oxide }\end{array}$ & $\begin{array}{c}\text { Norm. } \\
\text { Group 1 } \\
\text { Parent }\end{array}$ & Transition & Low SiO2 & $\begin{array}{c}\text { Low TiO2 } \\
\text { Group 1 }\end{array}$ & $\begin{array}{c}\text { High TiO2 } \\
\text { Group 1 }\end{array}$ & $\begin{array}{c}\text { Average } \\
\text { Group 1 }\end{array}$ \\
\hline SiO2 & 53.75 & 55.66 & 57.49 & 62.38 & 59.95 & 61.17 \\
TiO2 & 2.99 & 2.30 & 2.39 & 1.30 & 1.97 & 1.63 \\
Al2O3 & 14.07 & 13.80 & 13.41 & 13.22 & 13.29 & 13.25 \\
FeO* & 11.73 & 12.13 & 11.38 & 10.43 & 10.65 & 10.54 \\
MnO & 0.19 & 0.20 & 0.53 & 0.23 & 0.23 & 0.23 \\
MgO & 3.32 & 3.30 & 2.43 & 0.93 & 1.69 & 1.31 \\
CaO & 7.72 & 7.15 & 6.47 & 4.43 & 5.29 & 4.86 \\
Na2O & 3.03 & 3.32 & 3.07 & 3.71 & 3.55 & 3.63 \\
K2O & 1.79 & 1.69 & 2.40 & 2.97 & 2.60 & 2.78 \\
P2O5 & 1.42 & 0.44 & 0.76 & 0.40 & 0.79 & 0.60 \\
Total & 100.00 & 100.00 & 100.35 & 100.00 & 100.00 & 100.00 \\
Compatible Trace & & & & & & \\
Sc & 17 & 33.13 & 29.13 & 26.02 & 26.82 & 25.74 \\
Ni & 7 & 9.90 & 5.97 & 2.16 & 3.38 & 2.72 \\
Cr & 37.2 & 7.08 & 0.00 & 0.88 & 0.23 & 0.54 \\
V & 330 & 322.66 & 153.55 & 13.80 & 50.87 & 32.37 \\
\hline \hline
\end{tabular}


Table D-2. Incompatible trace element bulk rock geochemistry for group 1 used in crystallization model.

\begin{tabular}{ccccccc}
\hline \hline $\begin{array}{c}\text { Incompatible } \\
\text { Trace }\end{array}$ & $\begin{array}{c}\text { Norm. } \\
\text { Group 1 } \\
\text { Parent }\end{array}$ & Transition & Low SiO2 & $\begin{array}{c}\text { Low TiO2 } \\
\text { Group 1 }\end{array}$ & $\begin{array}{c}\text { High TiO2 } \\
\text { Group 1 }\end{array}$ & $\begin{array}{c}\text { Average } \\
\text { Group 1 }\end{array}$ \\
\hline Rb & 41.16 & 42.46 & 38.18 & 80.60 & 64.60 & 72.60 \\
Ba & 874.00 & 705.42 & 938.64 & 1162.19 & 1097.67 & 1125.30 \\
Th & 6.140 & 5.23 & 5.27 & 9.09 & 8.11 & 8.60 \\
U & 1.67 & 1.55 & 2.33 & 2.66 & 2.31 & 2.48 \\
Nb & 10.60 & 13.36 & 14.79 & 21.72 & 17.65 & 19.68 \\
Ta & 0.80 & 0.88 & 0.96 & 1.36 & 1.16 & 1.26 \\
K & 15194 & 14093 & 16054.91 & 24665.98 & 21638.39 & 23126.94 \\
La & 33.68 & 26.77 & 31.12 & 43.70 & 40.11 & 41.97 \\
Ce & 67.07 & 56.02 & 64.03 & 91.63 & 81.74 & 86.69 \\
Pb & 15.31 & 12.13 & 8.30 & 13.51 & 14.54 & 15.37 \\
Pr & 9.200 & 7.44 & 8.80 & 11.95 & 10.86 & 11.42 \\
Sr & 374.350 & 339.99 & 373.73 & 299.36 & 326.77 & 312.70 \\
P & 6337 & 1937 & 3910.43 & 1737.82 & 3459.37 & 2597.09 \\
Nd & 40.85 & 31.88 & 37.55 & 49.75 & 46.22 & 48.03 \\
Zr & 154.73 & 201.81 & 221.21 & 324.10 & 264.56 & 294.36 \\
Hf & 4.28 & 5.37 & 5.78 & 8.50 & 7.02 & 7.76 \\
Sm & 5.89 & 7.76 & 9.00 & 11.70 & 11.12 & 11.42 \\
Eu & 2.86 & 2.38 & 2.77 & 3.46 & 3.21 & 3.34 \\
Ti & 18375 & 13789 & 12138.61 & 7790.07 & 11784.36 & 9788.02 \\
Tb & 1.73 & 1.33 & 1.48 & 1.92 & 1.86 & 1.90 \\
Dy & 10.45 & 8.09 & 8.94 & 11.80 & 11.35 & 11.59 \\
Y & 53.69 & 41.30 & 46.77 & 61.75 & 59.43 & 60.59 \\
Yb & 4.298 & 3.83 & 4.25 & 5.92 & 5.35 & 5.63 \\
Lu & 0.632 & 0.60 & 0.68 & 0.96 & 0.84 & 0.90 \\
Gd & 10.91 & 8.02 & 9.03 & 11.58 & 11.41 & 11.50 \\
Ho & 2.09 & 1.64 & 1.83 & 2.43 & 2.32 & 2.38 \\
Er & 5.52 & 4.42 & 4.88 & 6.59 & 6.22 & 6.41 \\
Tm & 0.724 & 0.63 & 0.69 & 0.95 & 0.87 & 0.91 \\
\hline \hline & & & & & & \\
\hline
\end{tabular}


Table D-3. Major and compatible trace element bulk rock geochemistry for group 2 used in crystallization model.

\begin{tabular}{ccccccc}
\hline \hline $\begin{array}{c}\text { Major } \\
\text { Element } \\
\text { Oxide }\end{array}$ & $\begin{array}{c}\text { Norm. } \\
\text { Group 2 } \\
\text { Parent }\end{array}$ & Transition & Low SiO2 & $\begin{array}{c}\text { Low TiO2 } \\
\text { Group 2 }\end{array}$ & $\begin{array}{c}\text { High TiO2 } \\
\text { Group 2 }\end{array}$ & $\begin{array}{c}\text { Average } \\
\text { Group 2 }\end{array}$ \\
\hline SiO2 & 53.29 & 55.66 & 57.49 & 61.20 & 60.70 & 60.95 \\
TiO2 & 2.41 & 2.30 & 2.39 & 1.33 & 1.51 & 1.42 \\
Al2O3 & 14.82 & 13.80 & 13.41 & 14.74 & 14.71 & 14.72 \\
FeO* & 10.56 & 12.13 & 11.38 & 9.76 & 9.64 & 9.70 \\
MnO & 0.17 & 0.20 & 0.53 & 0.18 & 0.18 & 0.18 \\
MgO & 3.97 & 3.30 & 2.43 & 1.63 & 1.51 & 1.57 \\
CaO & 9.07 & 7.15 & 6.47 & 4.94 & 5.05 & 5.00 \\
Na2O & 2.81 & 3.32 & 3.07 & 3.56 & 3.94 & 3.75 \\
K2O & 1.55 & 1.69 & 2.40 & 2.15 & 2.12 & 2.14 \\
P2O5 & 1.34 & 0.44 & 0.76 & 0.50 & 0.64 & 0.57 \\
Total & 100.00 & 100.00 & 100.35 & 100.00 & 100.00 & 100.00 \\
Compatible Trace & & & & & & \\
Sc & 31.00 & 33.13 & 29.13 & 26.25 & 27.58 & 26.10 \\
Ni & 18.00 & 9.90 & 5.97 & 3.83 & 4.12 & 3.97 \\
Cr & 36.00 & 7.08 & 0.00 & 1.35 & 4.01 & 2.68 \\
V & 350.00 & 322.66 & 153.55 & 86.01 & 78.47 & 82.24 \\
\hline \hline
\end{tabular}


Table D-4. Incompatible trace element bulk rock geochemistry for group 1 used in crystallization model.

\begin{tabular}{ccccccc}
\hline \hline $\begin{array}{c}\text { Incompatible } \\
\text { Trace }\end{array}$ & $\begin{array}{c}\text { Norm. } \\
\text { Group 2 } \\
\text { Parent }\end{array}$ & Transition & Low SiO2 & $\begin{array}{c}\text { Low TiO2 } \\
\text { Group 2 }\end{array}$ & $\begin{array}{c}\text { High TiO2 } \\
\text { Group 2 }\end{array}$ & $\begin{array}{c}\text { Average } \\
\text { Group 2 }\end{array}$ \\
\hline Rb & 24.79 & 42.46 & 38.18 & 47.38 & 43.04 & 45.21 \\
Ba & 713.00 & 705.42 & 938.64 & 904.04 & 904.61 & 904.32 \\
Th & 2.60 & 5.23 & 5.27 & 4.38 & 4.31 & 4.35 \\
U & 1.25 & 1.55 & 2.33 & 2.15 & 2.17 & 2.16 \\
Nb & 15.15 & 13.36 & 14.79 & 9.99 & 11.31 & 10.65 \\
Ta & 1.00 & 0.88 & 0.96 & 0.64 & 0.71 & 0.68 \\
K & 13320.35 & 14093.46 & 16054.91 & 17860.30 & 17651.47 & 17755.89 \\
La & 30.17 & 26.77 & 31.12 & 23.49 & 25.79 & 24.64 \\
Ce & 66.64 & 56.02 & 64.03 & 49.87 & 55.15 & 52.51 \\
Pb & 5.47 & 12.13 & 8.30 & 9.06 & 10.68 & 9.87 \\
Pr & 9.75 & 7.44 & 8.80 & 7.00 & 7.80 & 7.40 \\
Sr & 498.97 & 339.99 & 373.73 & 298.43 & 342.22 & 320.32 \\
P & 6039.65 & 1936.60 & 3910.43 & 2197.39 & 2775.41 & 2486.40 \\
Nd & 43.42 & 31.88 & 37.55 & 30.25 & 33.73 & 31.99 \\
Zr & 179.46 & 201.81 & 221.21 & 197.14 & 194.73 & 195.93 \\
Hf & 6.66 & 5.37 & 5.78 & 5.27 & 5.12 & 5.19 \\
Sm & 10.57 & 7.76 & 9.00 & 7.54 & 8.38 & 7.96 \\
Eu & 3.71 & 2.38 & 2.77 & 2.03 & 2.45 & 2.24 \\
Ti & 14937.50 & 13789.44 & 12138.61 & 7983.95 & 9022.65 & 8503.30 \\
Tb & 1.59 & 1.33 & 1.48 & 1.37 & 1.46 & 1.41 \\
Dy & 10.22 & 8.09 & 8.94 & 8.70 & 9.00 & 8.85 \\
Y & 49.02 & 41.30 & 46.77 & 47.99 & 48.02 & 48.01 \\
Yb & 4.23 & 3.83 & 4.25 & 4.71 & 4.72 & 4.71 \\
Lu & 0.65 & 0.60 & 0.68 & 0.76 & 0.76 & 0.76 \\
Gd & 10.91 & 8.02 & 9.03 & 7.99 & 8.69 & 8.34 \\
Ho & 1.97 & 1.64 & 1.83 & 1.84 & 1.88 & 1.86 \\
Er & 4.99 & 4.42 & 4.88 & 5.10 & 5.15 & 5.13 \\
Tm & 0.72 & 0.63 & 0.69 & 0.74 & 0.75 & 0.75 \\
\hline \hline
\end{tabular}


Table D-5. Group 1 model calculated values

\begin{tabular}{|c|c|c|c|c|c|c|c|c|c|c|c|c|}
\hline $\begin{array}{c}\% \text { melt } \\
\text { crystallized }\end{array}$ & 0.05 & 0.10 & 0.15 & 0.20 & 0.25 & 0.30 & 0.35 & 0.40 & 0.45 & 0.50 & $\begin{array}{c}\text { Group } 1 \\
\text { Parent }\end{array}$ & Assemblage \\
\hline $\mathrm{SiO2}$ & 54.43 & 55.18 & 56.03 & 56.98 & 58.05 & 59.28 & 60.70 & 62.35 & 64.31 & 66.66 & 53.75 & 40.84 \\
\hline TiO2 & 2.91 & 2.83 & 2.73 & 2.63 & 2.51 & 2.37 & 2.21 & 2.03 & 1.81 & 1.54 & 2.99 & 4.44 \\
\hline Al203 & 13.98 & 13.87 & 13.76 & 13.63 & 13.48 & 13.31 & 13.11 & 12.88 & 12.61 & 12.29 & 14.07 & 15.86 \\
\hline $\mathrm{FeO}$ & 11.51 & 11.26 & 10.99 & 10.68 & 10.34 & 9.94 & 9.48 & 8.95 & 8.31 & 7.56 & 11.73 & 15.90 \\
\hline MnO & 0.19 & 0.20 & 0.21 & 0.22 & 0.23 & 0.24 & 0.25 & 0.27 & 0.28 & 0.31 & 0.19 & 0.07 \\
\hline MgO & 3.09 & 2.84 & 2.56 & 2.24 & 1.88 & 1.46 & 0.98 & 0.43 & -0.23 & -1.02 & 3.32 & 7.66 \\
\hline $\mathrm{CaO}$ & 7.48 & 7.21 & 6.90 & 6.56 & 6.18 & 5.73 & 5.23 & 4.63 & 3.93 & 3.09 & 7.72 & 12.35 \\
\hline $\mathrm{Na2O}$ & 3.10 & 3.17 & 3.26 & 3.35 & 3.46 & 3.58 & 3.73 & 3.89 & 4.09 & 4.32 & 3.03 & 1.74 \\
\hline K2O & 1.88 & 1.98 & 2.10 & 2.23 & 2.37 & 2.54 & 2.73 & 2.95 & 3.22 & 3.54 & 1.79 & 0.04 \\
\hline P205 & 1.49 & 1.57 & 1.67 & 1.77 & 1.89 & 2.02 & 2.18 & 2.36 & 2.58 & 2.83 & 1.42 & 0.00 \\
\hline Total & 100.06 & 100.12 & 100.20 & 100.28 & 100.37 & 100.47 & 100.60 & 100.74 & 100.91 & 101.11 & 100.00 & 99.35 \\
\hline
\end{tabular}

$\stackrel{\omega}{\oplus}$ 
Table D-6. Group 2 model calculated values.

\begin{tabular}{|c|c|c|c|c|c|c|c|c|c|c|c|c|}
\hline $\begin{array}{c}\% \text { melt } \\
\text { crystallized }\end{array}$ & 0.05 & 0.10 & 0.15 & 0.20 & 0.25 & 0.30 & 0.35 & 0.40 & 0.45 & 0.50 & $\begin{array}{c}\text { Group } 2 \\
\text { Parent }\end{array}$ & Assemblage \\
\hline $\mathrm{SiO} 2$ & 53.83 & 54.43 & 55.10 & 55.86 & 56.71 & 57.69 & 58.82 & 60.14 & 61.70 & 63.56 & 53.29 & 43.01 \\
\hline TiO2 & 2.37 & 2.32 & 2.27 & 2.21 & 2.15 & 2.07 & 1.99 & 1.89 & 1.77 & 1.62 & 2.41 & 3.20 \\
\hline Al203 & 14.58 & 14.31 & 14.01 & 13.67 & 13.28 & 12.84 & 12.34 & 11.74 & 11.04 & 10.20 & 14.82 & 19.44 \\
\hline FeO & 10.47 & 10.38 & 10.27 & 10.15 & 10.01 & 9.85 & 9.67 & 9.46 & 9.20 & 8.90 & 10.56 & 12.22 \\
\hline MnO & 0.18 & 0.19 & 0.20 & 0.20 & 0.21 & 0.22 & 0.24 & 0.25 & 0.27 & 0.29 & 0.17 & 0.06 \\
\hline MgO & 3.80 & 3.61 & 3.40 & 3.16 & 2.89 & 2.58 & 2.23 & 1.81 & 1.32 & 0.73 & 3.97 & 7.21 \\
\hline $\mathrm{CaO}$ & 8.92 & 8.76 & 8.58 & 8.38 & 8.15 & 7.89 & 7.59 & 7.24 & 6.82 & 6.32 & 9.07 & 11.81 \\
\hline $\mathrm{Na2O}$ & 2.85 & 2.89 & 2.93 & 2.99 & 3.04 & 3.11 & 3.19 & 3.28 & 3.38 & 3.51 & 2.81 & 2.11 \\
\hline K2O & 1.63 & 1.72 & 1.81 & 1.92 & 2.05 & 2.19 & 2.36 & 2.55 & 2.78 & 3.05 & 1.55 & 0.05 \\
\hline P2O5 & 1.41 & 1.49 & 1.57 & 1.67 & 1.78 & 1.91 & 2.06 & 2.23 & 2.43 & 2.67 & 1.34 & 0.00 \\
\hline Total & 100.05 & 100.10 & 100.15 & 100.22 & 100.29 & 100.38 & 100.47 & 100.58 & 100.72 & 100.88 & 100.00 & 99.12 \\
\hline
\end{tabular}




\section{Appendix E: Magma Mixing Model}

Table E-1. Average icelandite group 1 and 2 geochemistry and GRB like mafic endmembers used in mixing models. All elemental concentrations are in units of ppm.

\begin{tabular}{|c|c|c|c|c|}
\hline Element & $\begin{array}{c}\text { Average Group } \\
1\end{array}$ & $\begin{array}{c}\text { Average Group } \\
2\end{array}$ & $\begin{array}{l}\text { Mafic Endmember } \\
\text { Group } 1\end{array}$ & $\begin{array}{c}\text { Mafic Endmember } \\
\text { Group } 2\end{array}$ \\
\hline $\mathbf{R b}$ & 72.6 & 45.21 & 41.16 & 24.79 \\
\hline $\mathrm{Ba}$ & 1125 & 904 & 874 & 713 \\
\hline Th & 8.6 & 4.35 & 6.14 & 2.6 \\
\hline U & 2.48 & 2.16 & 1.67 & 1.25 \\
\hline Nb & 19.68 & 10.65 & 10.6 & 15.15 \\
\hline Ta & 1.26 & 0.68 & 0.8 & 1 \\
\hline K & 23127 & 17756 & 15194 & 13320 \\
\hline La & 41.97 & 24.64 & 33.68 & 30.17 \\
\hline $\mathrm{Ce}$ & 86.69 & 52.51 & 67.07 & 66.64 \\
\hline $\mathrm{Pb}$ & 15.37 & 9.87 & 15.31 & 5.47 \\
\hline $\operatorname{Pr}$ & 11.42 & 7.4 & 9.2 & 9.747 \\
\hline $\mathrm{Sr}$ & 312.7 & 320.32 & 374.35 & 498.97 \\
\hline $\mathbf{P}$ & 2597 & 2486 & 6337 & 6040 \\
\hline Nd & 48.03 & 31.99 & 40.85 & 43.42 \\
\hline $\mathrm{Zr}$ & 294.36 & 195.93 & 154.73 & 179.46 \\
\hline Hf & 7.76 & 5.19 & 4.28 & 6.659 \\
\hline Sm & 11.42 & 7.96 & 10.15 & 10.57 \\
\hline Eu & 3.34 & 2.24 & 2.86 & 2.05 \\
\hline $\mathrm{Ti}$ & 9788 & 8503 & 18375 & 14938 \\
\hline $\mathrm{Tb}$ & 1.9 & 1.41 & 1.73 & 1.59 \\
\hline Dy & 11.59 & 8.85 & 10.45 & 10.22 \\
\hline$Y$ & 60.59 & 48.01 & 53.69 & 49.02 \\
\hline $\mathrm{Yb}$ & 5.63 & 4.71 & 4.298 & 4.23 \\
\hline Lu & 0.9 & 0.76 & 0.632 & 0.647 \\
\hline Gd & 11.5 & 8.34 & 10.91 & 10.91 \\
\hline Ho & 2.38 & 1.86 & 2.09 & 1.97 \\
\hline Er & 6.41 & 5.13 & 5.52 & 4.99 \\
\hline $\mathrm{Tm}$ & 0.91 & 0.75 & 0.724 & 0.72 \\
\hline
\end{tabular}


Table E-2. Average icelandite group 1 and 2 geochemistry and GRB like mafic endmembers used in mixing models. All elemental concentrations are in units of ppm.

\begin{tabular}{|c|c|c|c|c|c|c|}
\hline Element & $\begin{array}{l}\text { Average } \\
\text { Lower } \\
\text { Littlefield }\end{array}$ & $\begin{array}{l}\text { Average } \\
\text { Upper } \\
\text { Littlefield }\end{array}$ & $\begin{array}{c}\text { Average } \\
\text { DIT } 1\end{array}$ & $\begin{array}{c}\text { Average } \\
\text { DIT } 2\end{array}$ & $\begin{array}{c}\text { Average } \\
\text { DIT } 3\end{array}$ & $\begin{array}{c}\text { Average } \\
\text { DIT } 4\end{array}$ \\
\hline $\mathbf{R b}$ & 144.93 & 108.25 & 63.89 & 74.25 & 88.49 & 50.97 \\
\hline $\mathrm{Ba}$ & 1338 & 1689 & 1297 & 1447 & 1083 & 1253 \\
\hline Th & 16.44 & 12.81 & 6.98 & 7.08 & 7.35 & 5.01 \\
\hline U & 5.21 & 3.65 & 2.95 & 3.06 & 3.28 & 2.18 \\
\hline $\mathrm{Nb}$ & 19.75 & 32.24 & 20 & 17.73 & 23.95 & 15.54 \\
\hline Ta & 1.49 & 2.03 & 1.23 & 1.14 & 1.43 & 0.99 \\
\hline K & 43539 & 39820 & 32113 & 35614 & 42618 & 23284 \\
\hline La & 79.54 & 57.95 & 38.72 & 39.41 & 41.41 & 30.49 \\
\hline $\mathrm{Ce}$ & 93.69 & 118.1 & 77.16 & 78.9 & 87.71 & 62.61 \\
\hline $\mathbf{P b}$ & 23.76 & 17.96 & 14.71 & 13.86 & 14.88 & 10.16 \\
\hline $\operatorname{Pr}$ & 11.24 & 15.01 & 10.44 & 10.5 & 11.04 & 8.38 \\
\hline $\mathrm{Sr}$ & 169.69 & 176.5 & 191.64 & 127.08 & 56.63 & 220.03 \\
\hline $\mathbf{P}$ & 608 & 233 & 268 & 210 & 415 & 1460 \\
\hline Nd & 85.64 & 60.43 & 41.39 & 42.24 & 43.63 & 34.84 \\
\hline $\mathrm{Zr}$ & 321.46 & 504.5 & 381.4 & 364.11 & 365.79 & 255.52 \\
\hline $\mathrm{Hf}$ & 8.54 & 13.04 & 10.13 & 9.45 & 9.48 & 6.67 \\
\hline Sm & 9.24 & 14.04 & 9.55 & 9.88 & 10.13 & 8.16 \\
\hline Eu & 2.65 & 3.47 & 1.59 & 1.93 & 1.68 & 2.21 \\
\hline $\mathrm{Ti}$ & 4233 & 2398 & 1762 & 1883 & 2524 & 6142 \\
\hline Tb & 1.38 & 2.41 & 1.79 & 1.79 & 1.78 & 1.44 \\
\hline Dy & 8.31 & 15.08 & 11.98 & 11.7 & 11.44 & 9.18 \\
\hline $\mathbf{Y}$ & 43.43 & 79.02 & 67.59 & 65.12 & 63.04 & 51.11 \\
\hline $\mathrm{Yb}$ & 4.22 & 8.06 & 7.88 & 6.98 & 6.72 & 5.13 \\
\hline Lu & 0.66 & 1.27 & 1.26 & 1.12 & 1.08 & 0.84 \\
\hline Gd & 8.35 & 13.8 & 9.57 & 10 & 9.9 & 8.38 \\
\hline Ho & 1.69 & 3.13 & 2.62 & 2.5 & 2.42 & 1.94 \\
\hline Er & 4.6 & 8.68 & 7.68 & 7.13 & 6.85 & 5.42 \\
\hline $\mathrm{Tm}$ & 0.67 & 1.28 & 1.2 & 1.08 & 1.04 & 0.81 \\
\hline
\end{tabular}


LOWER LitTLEFIELD RHYOLITE MiXING Plots
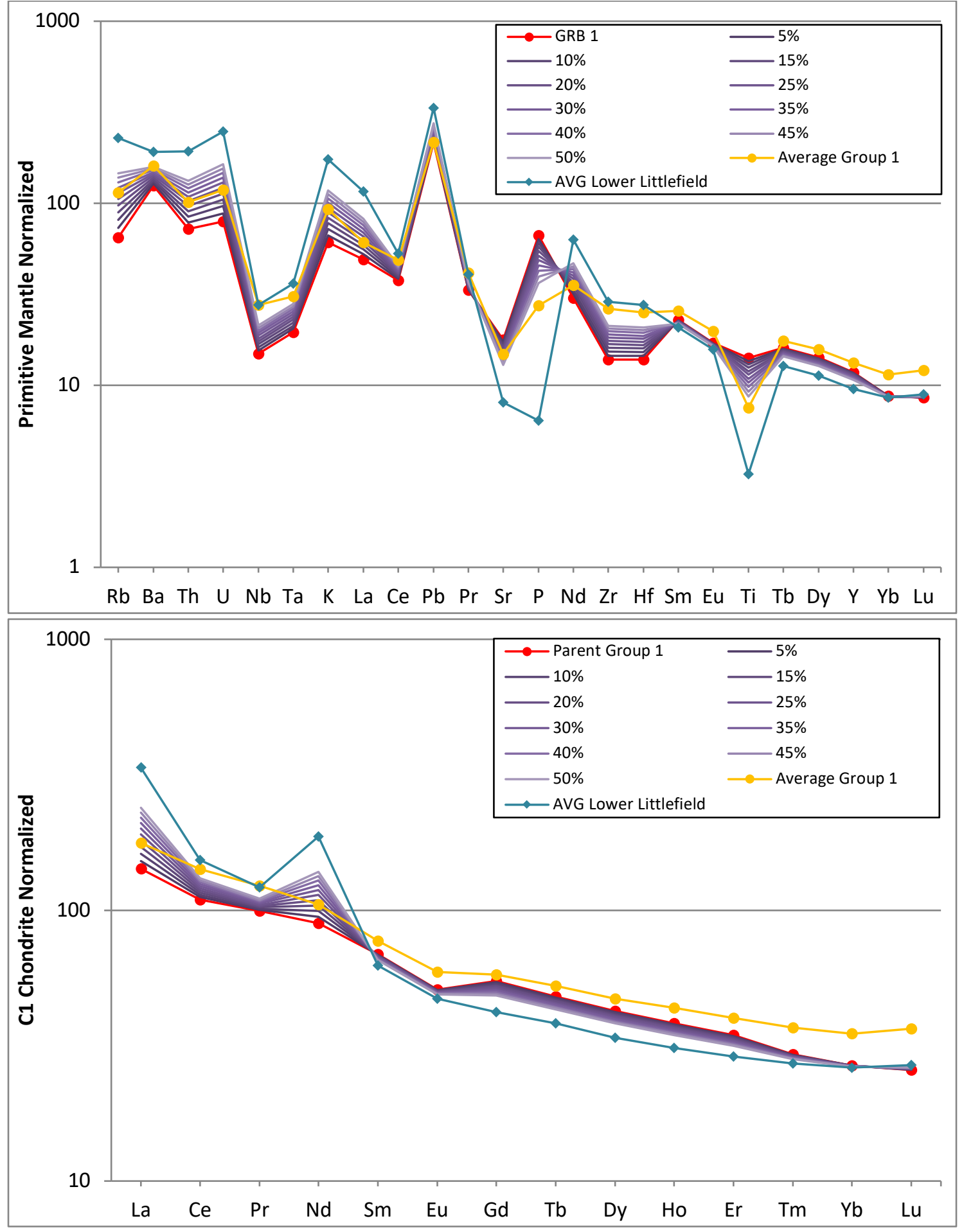

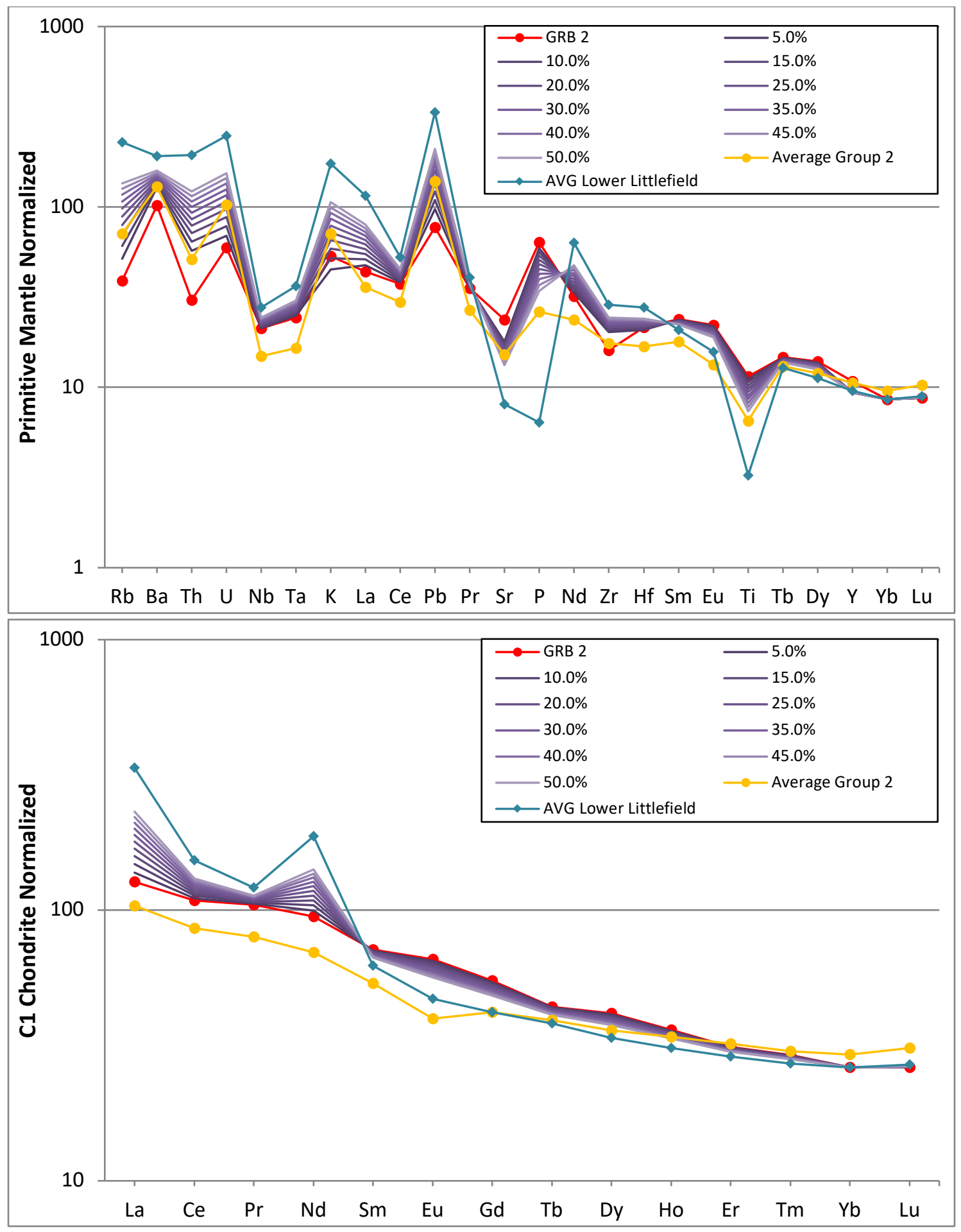
UPPeR LITTLEFIELD RHYOLITE MiXING PLOTS

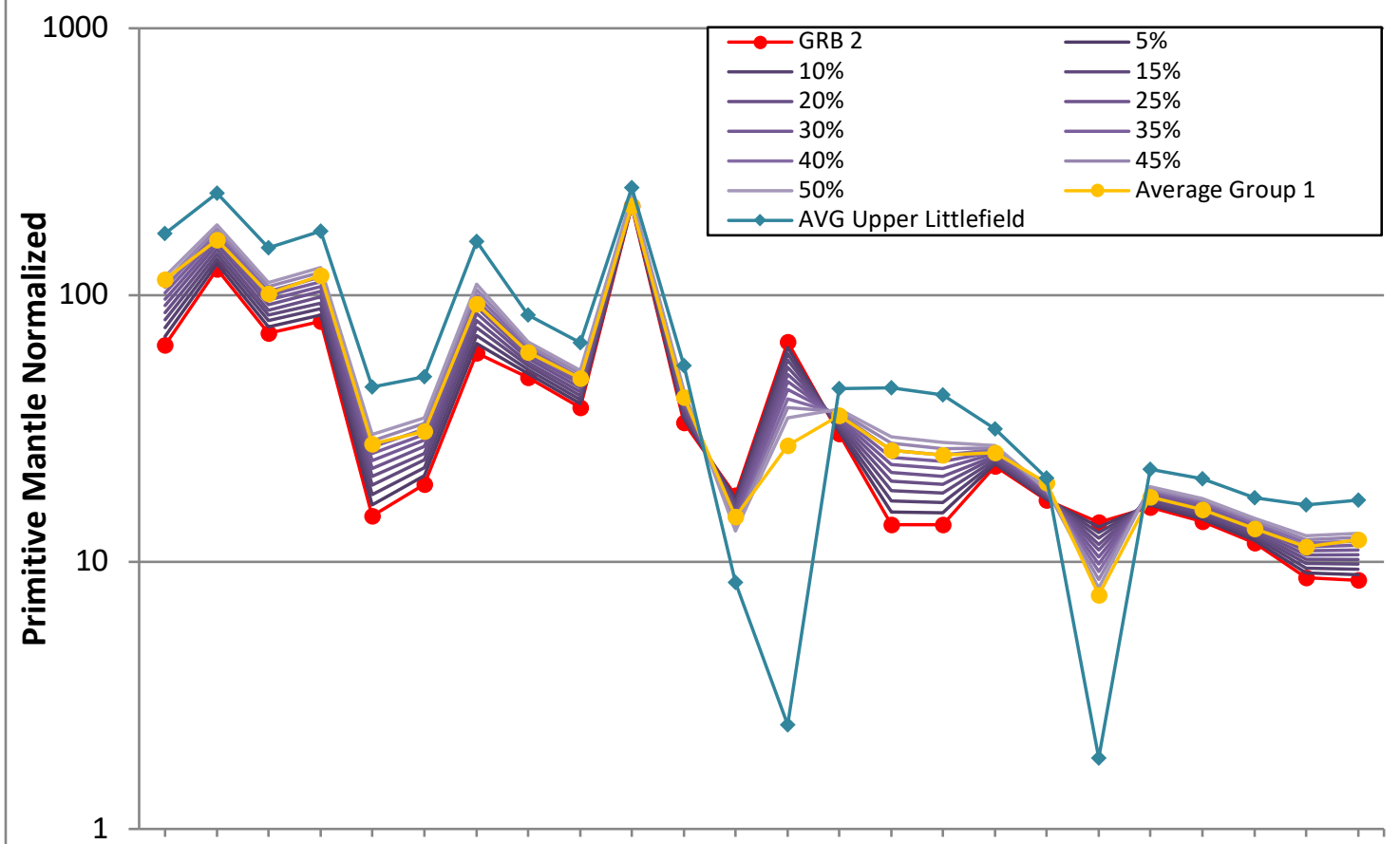

$\mathrm{Rb}$ Ba Th U Nb Ta K La Ce Pb Pr Sr P Nd Zr Hf Sm Eu Ti Tb Dy Y Yb Lu

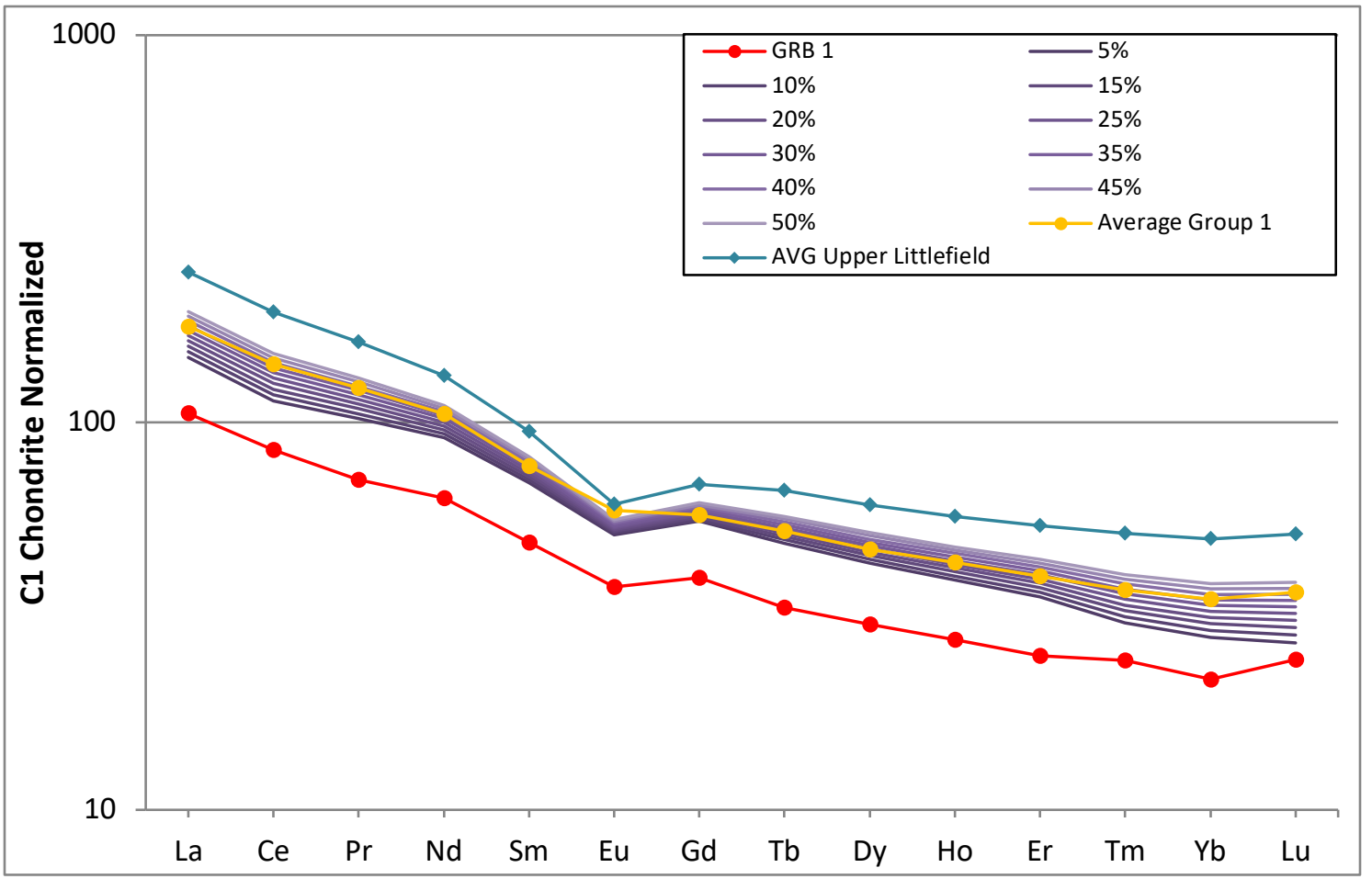




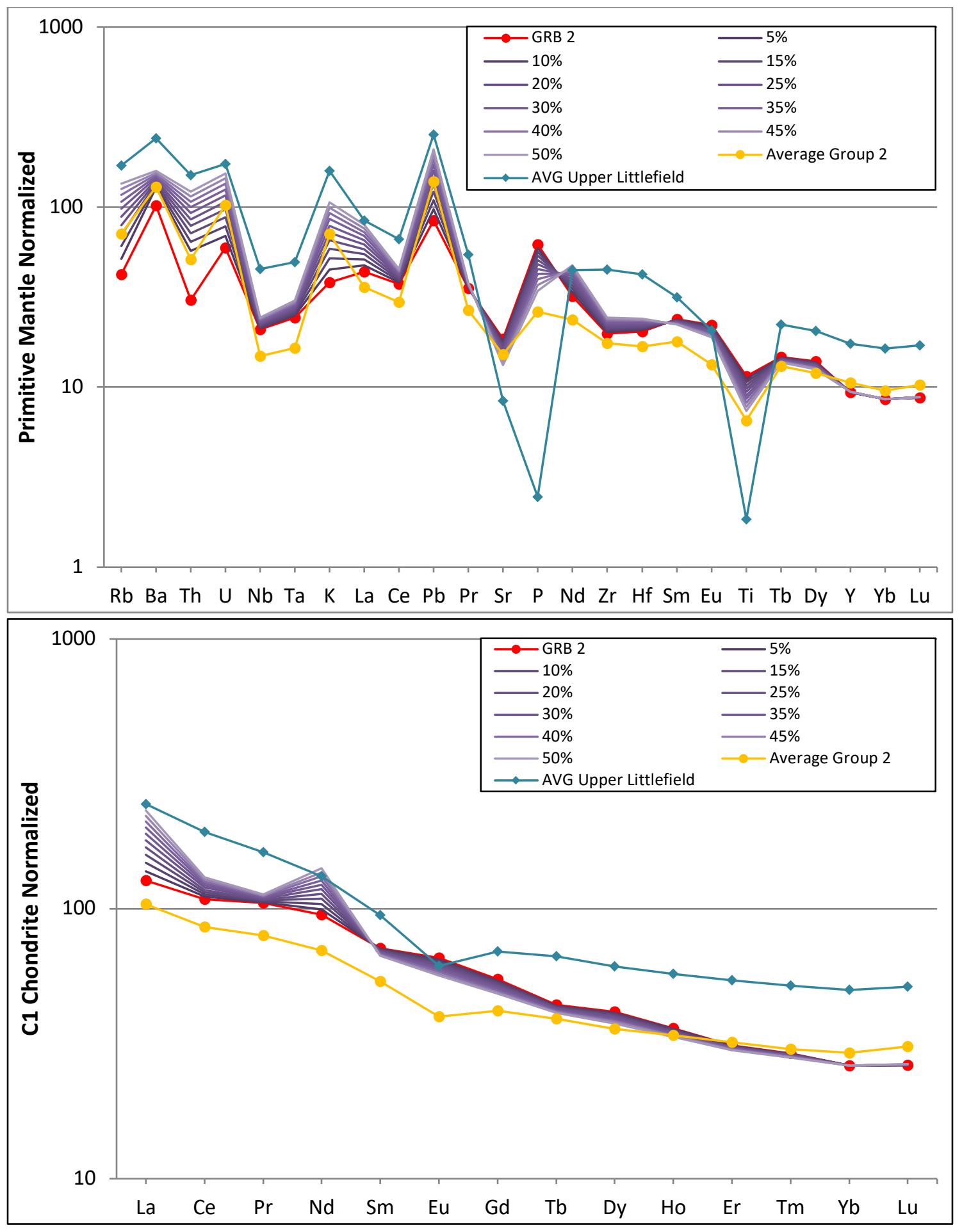


Dinner Creek Tuff Unit 1 Mixing Plots
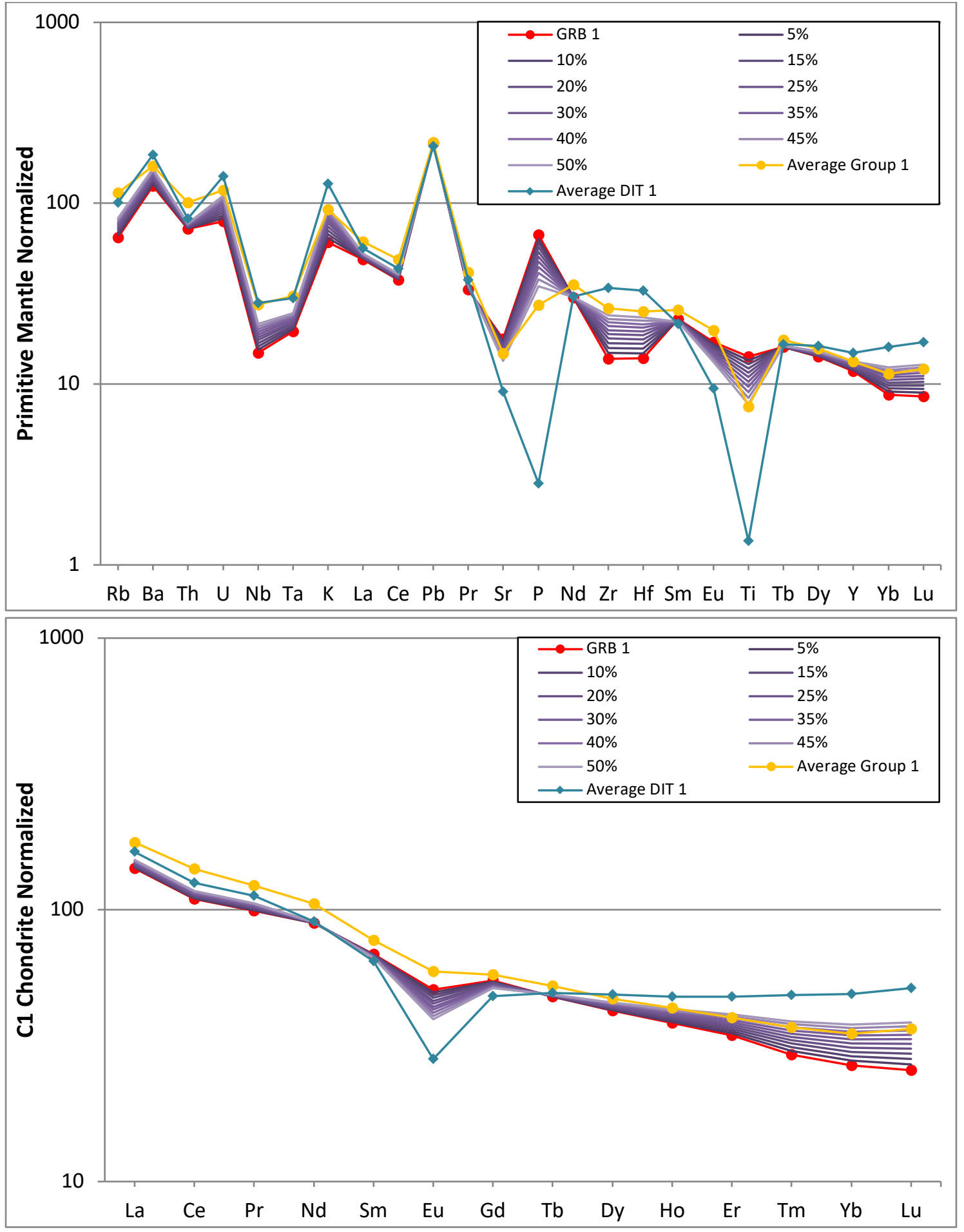


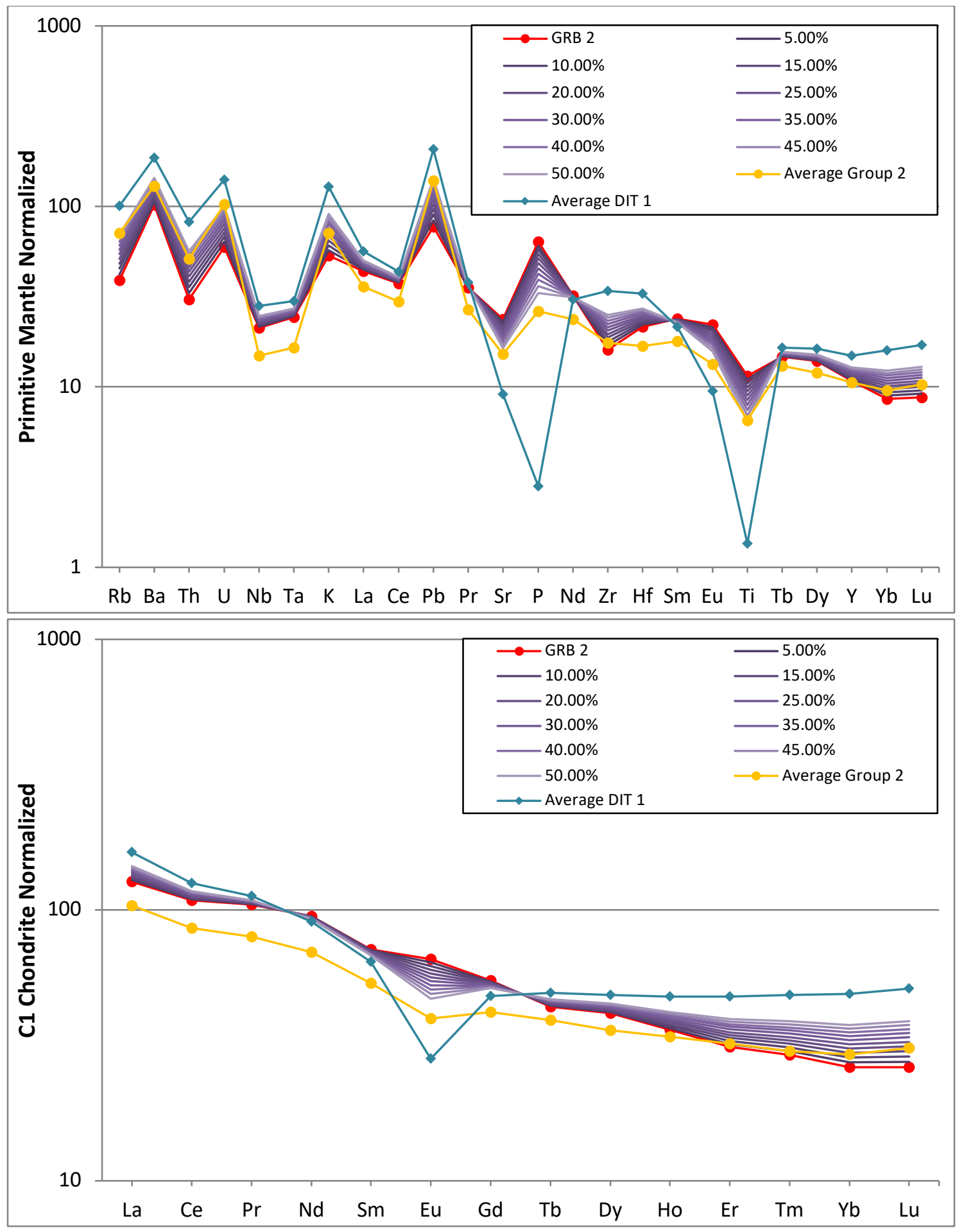


Dinner CReek Tuff Unit 2 MiXing Plots
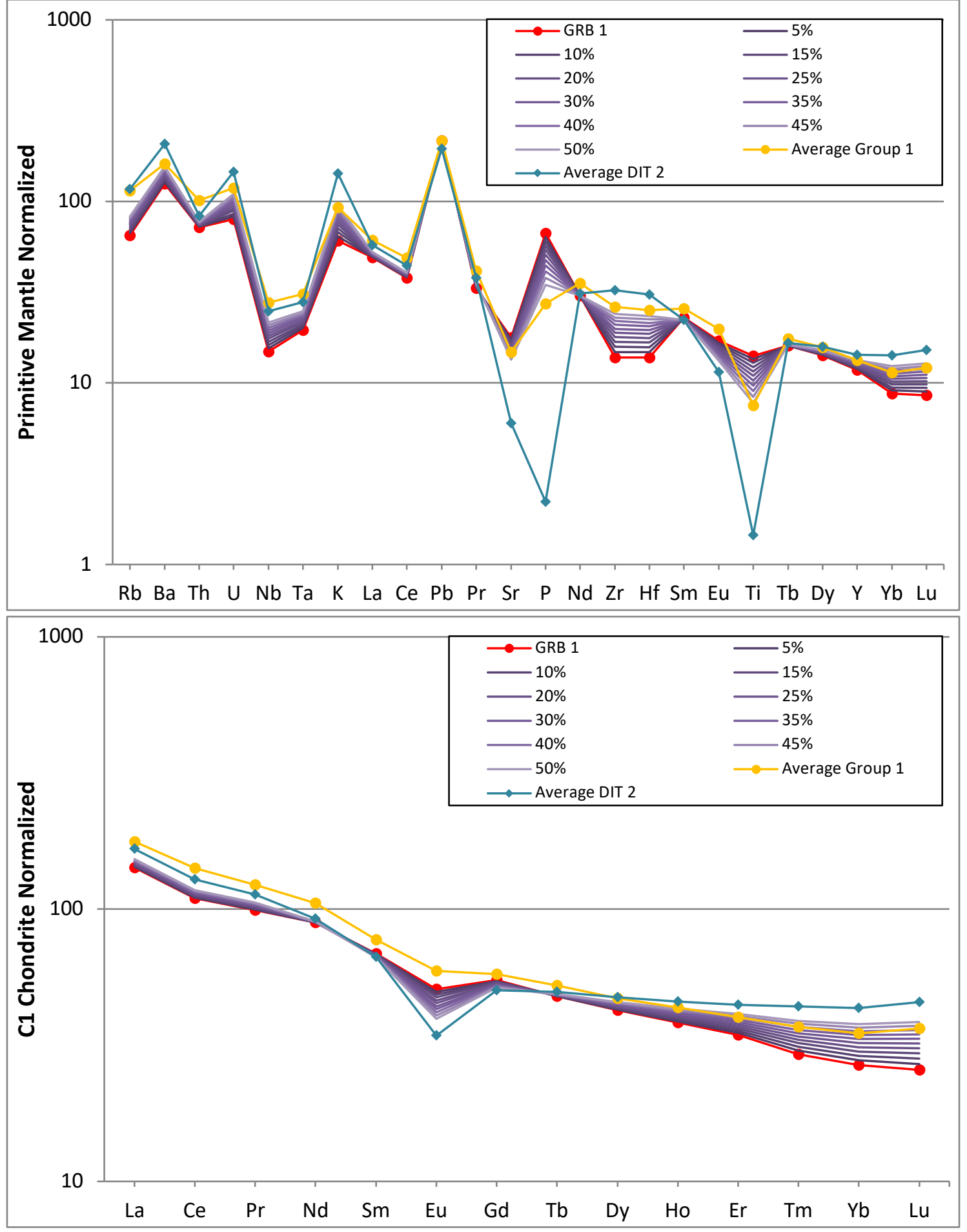

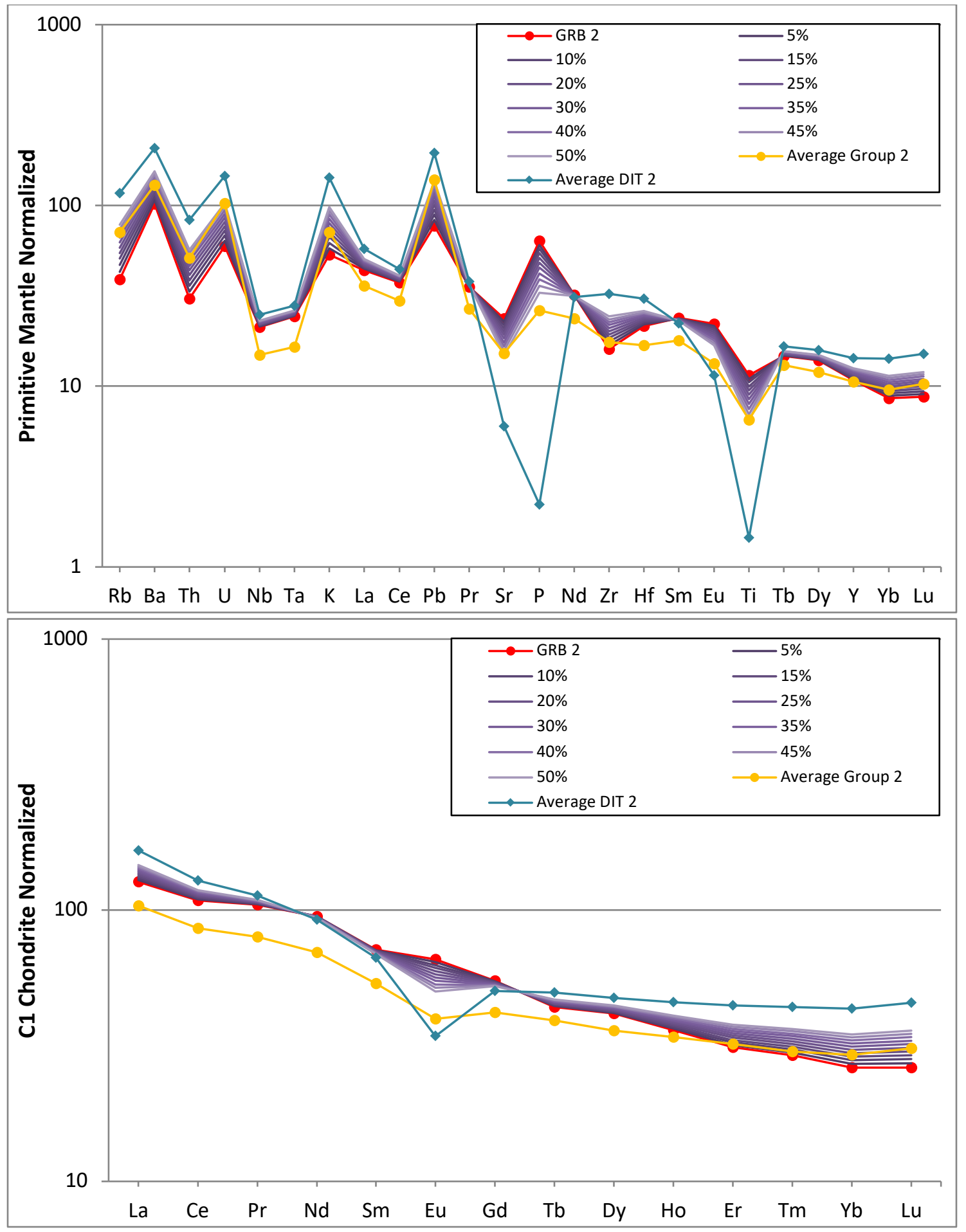
Dinner CReek Tuff Unit 3 MiXing Plots
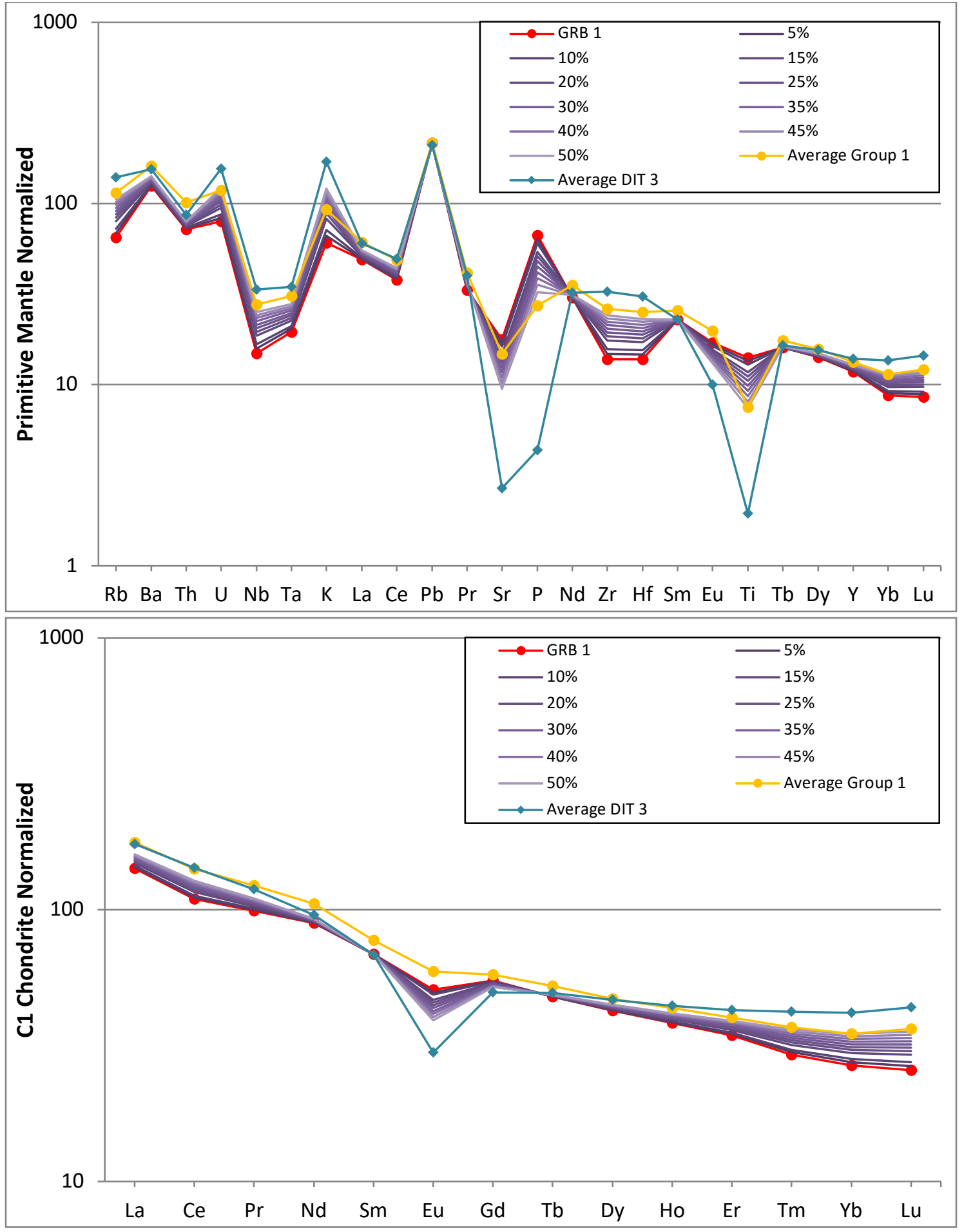


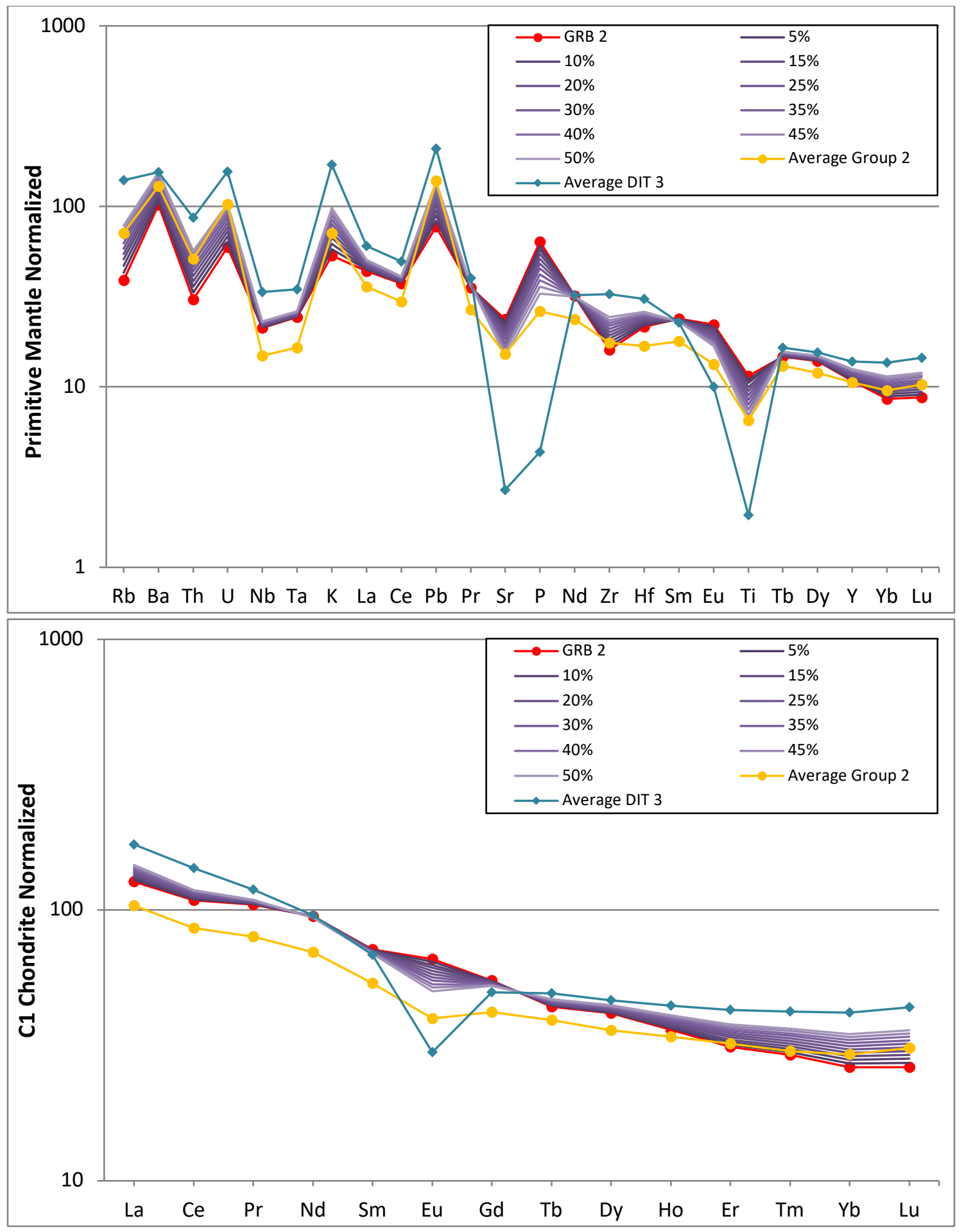


Dinner Creek Tuff Unit 4 Mixing Plots

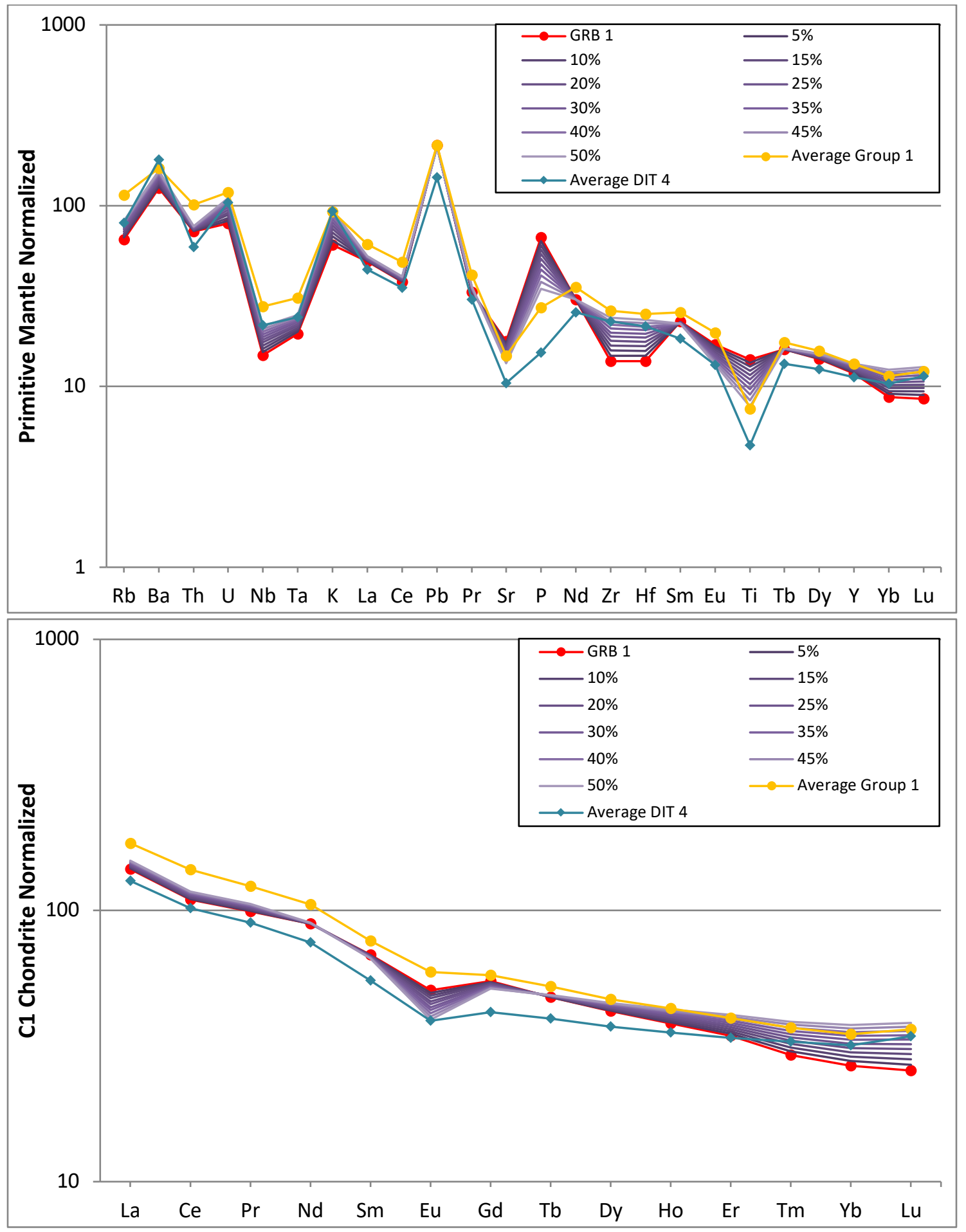




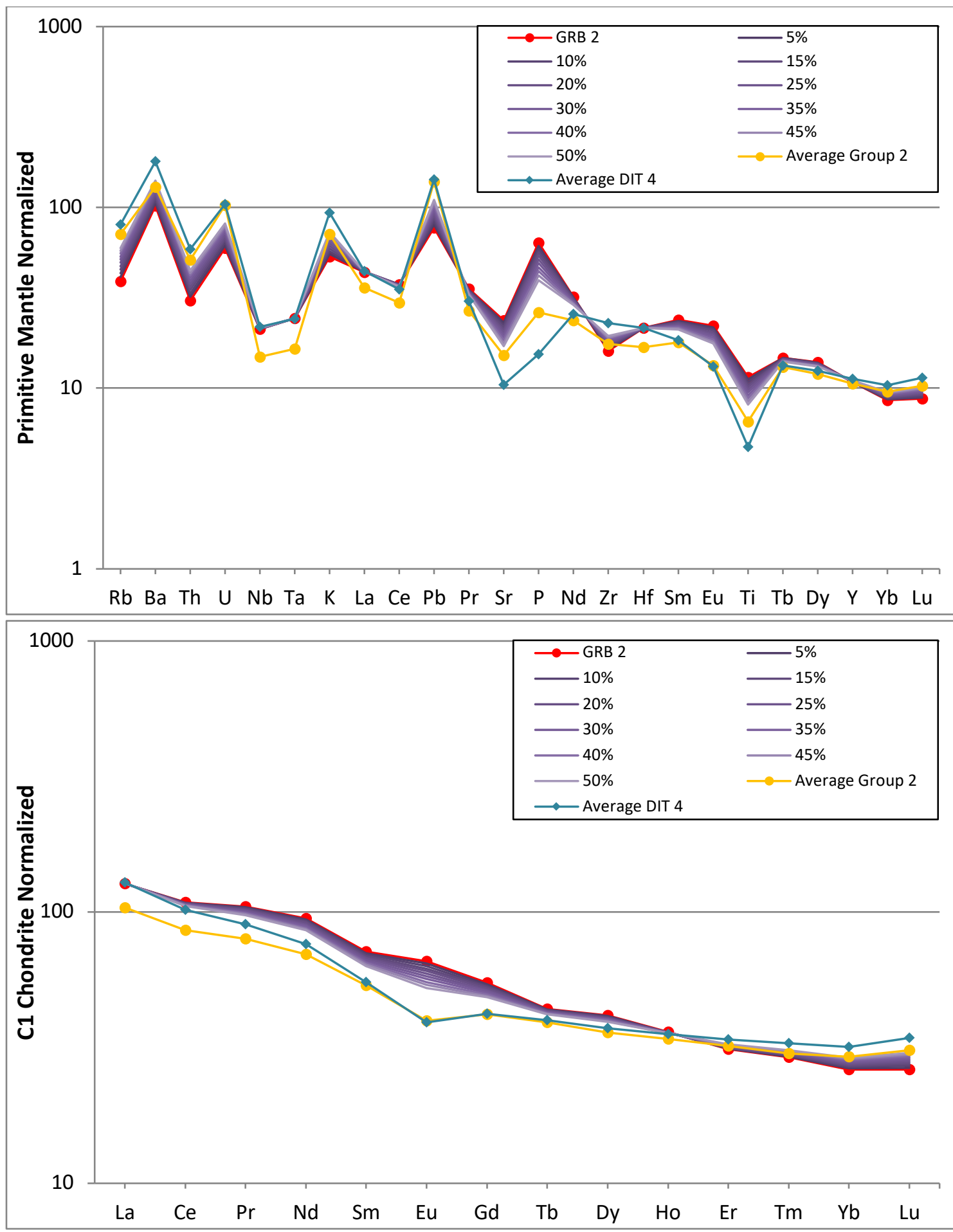




\section{Appendix F: Petrographic Analysis}

Table F-1. Locations of samples used for petrographic analysis and status of geochemical analysis.

\begin{tabular}{c|cccc}
\hline Sample ID & Easting (m) & Northing (m) & UTM Zone & $\begin{array}{c}\text { Geochemical } \\
\text { Analysis }\end{array}$ \\
\hline MAC-17-04a & 373668.06 & 5003693.36 & $11 \mathrm{~N}$ & Yes \\
MAC-17-06 & 376393.40 & 5005731.80 & $11 \mathrm{~N}$ & Yes \\
MAC-17-16 & 415699.62 & 5003692.37 & $11 \mathrm{~N}$ & Yes \\
MAC-17-18 & 412329.51 & 5038786.97 & $11 \mathrm{~N}$ & Yes \\
MAC-17-29 & 389606.53 & 5029335.61 & $11 \mathrm{~N}$ & Yes \\
MC-94-16 & 418812.57 & 4900676.68 & $11 \mathrm{~N}$ & Yes \\
MS-12-34 & 463326.29 & 4874738.45 & $11 \mathrm{~N}$ & Yes \\
BW-14-37A & 433140.00 & 4826063.21 & $11 \mathrm{~N}$ & Yes \\
BW-14-37B & 433167.00 & 4826016.21 & $11 \mathrm{~N}$ & Yes \\
MC-106-16 & 409638.45 & 4909351.14 & $11 \mathrm{~N}$ & Yes \\
MC-98-16 & 409980.37 & 4902902.89 & $11 \mathrm{~N}$ & No \\
MC-15-16 & 407222.62 & 4873690.51 & $11 \mathrm{~N}$ & No \\
MC-18-16 & 406509.06 & 4877655.42 & $11 \mathrm{~N}$ & No \\
MC-101-16 & 410314.97 & 4902622.79 & $11 \mathrm{~N}$ & No \\
\hline \hline
\end{tabular}


Table F-2. Petrographic analysis of thin sections.

\begin{tabular}{|c|c|c|c|}
\hline Sample ID & Unit & Rock & Description \\
\hline MAC-17-04a & Fiddlers Hell & Icelandite & $\begin{array}{l}\text { Aphanitic with groundmass matrix is a mix of plagioclase, } \\
\text { clinopyroxene, FeTi-oxide, and glass. groundmass }<63 \mu \mathrm{m} \text { in size. } \\
\text { Phenocrysts and microphenocryst of plag and } \mathrm{cpx} \text {. simple } \\
\text { twinning is present in plag phenocrysts. Some cpx appear to } \\
\text { have grown into and around microphenocrysts of plag. Plag are } \\
\text { mostly euhedral to subhedral. cpx range from anhedral to } \\
\text { subhedral and in shape. At least one cpx exhibits undulatory } \\
\text { extinction. Zoning present in larger phenocrysts of plagioclase. } \\
\text { plag phenocryst size from } 0.8 \text { to } 1.7 \mathrm{~mm} \text { and } \mathrm{cpx} \text { from } 0.8-1.2 \mathrm{~mm}\end{array}$ \\
\hline MAC-17-06 & Fiddlers Hell & Icelandite & $\begin{array}{l}\text { Aphanitic with groundmass matrix is a mix of plagioclase, } \\
\text { clinopyroxene, FeTi-oxide, and glass. Plag and cpx phenocrysts } \\
\text { and micro phenocrysts. cpx and plag exhibit twinning. Cpx is } \\
\text { anhedral to subhedral and plag is subhedral to euhedral. opaque } \\
\text { minerals are most likely to be magnetite. plag phenocryst size } \\
\text { from } 0.3 \text { to } 0.79 \mathrm{~mm} \text { and cpx from } 0.17-0.76 \mathrm{~mm} \text {. several plag } \\
\text { also have melt inclusions or secondary mineralization within } \\
\text { grain. }\end{array}$ \\
\hline MAC-17-16 & Fiddlers Hell & Icelandite & $\begin{array}{c}\text { Aphanitic with very fine-grained groundmass. Groundmass } \\
\text { matrix is a mix of plagioclase, clinopyroxene, FeTi-oxide, and } \\
\text { glass. Groundmass is more glassy than other thin sections of } \\
\text { Group. Phenocrysts of plag and cpx. Plag are euhedral and cpx } \\
\text { are euhedral to subhedral. fractured plag have secondary } \\
\text { mineralization in cracks. simple twinning in plag. plag } \\
\text { phenocrysts size from } 0.27 \text { to } 1.59 \mathrm{~mm} \text { and cpx from } 0.16-1.1 \\
\mathrm{~mm} .\end{array}$ \\
\hline MAC-17-18 & Fiddlers Hell & Icelandite & $\begin{array}{l}\text { Aphanitic with groundmass matrix is a mix of plagioclase, } \\
\text { clinopyroxene, FeTi-oxide, and glass. Groundmass is glassier } \\
\text { compared to previous sections. Large euhedral opaque minerals } \\
\text { are most likely magnetite. plag are mostly euhedral and cpx is } \\
\text { subhedral to anhedral. plag phenocrysts size from } 0.49 \text { to } 1.15 \\
\mathrm{~mm} \text { and cpx from } 0.36-1.34 \mathrm{~mm} \text {. plag exhibit simple twinning. } \\
\text { some plag crystals also have faint zoning. at least one pyroxene } \\
\text { appears to have twinning. }\end{array}$ \\
\hline MAC-17-29 & Fiddlers Hell & Icelandite & $\begin{array}{l}\text { Aphanitic with groundmass matrix is a mix of plagioclase, } \\
\text { clinopyroxene, FeTi-oxide, and glass. plag phenocrysts range in } \\
\text { size from } 0.34 \text { to } 0.94 \mathrm{~mm} \text { and cpx of } 0.22-0.63 \mathrm{~mm} \text {. brown } \\
\text { secondary mineralization present in thin section ground mass } \\
\text { and in fractured plagioclase. plag have simple twinning. }\end{array}$ \\
\hline MC-94-16 & $\begin{array}{c}\text { Hunter Creek } \\
\text { Basalt }\end{array}$ & Icelandite & $\begin{array}{l}\text { Aphanitic with very fine-grained groundmass. Groundmass } \\
\text { matrix is a mix of plagioclase, clinopyroxene, FeTi-oxide, and } \\
\text { glass. Plag phenocrysts present are euhedral laths with simple } \\
\text { twinning, cpx micro phenocrysts also present but are sparse. Cpx } \\
\text { micro phenocrysts are anhedral to slightly subhedral. one } \\
\text { phenocryst of plag? looks to have embayed crystal and also has } \\
\text { reaction rim on exterior of crystal as well as the exterior of the } \\
\text { embayed crystal. }\end{array}$ \\
\hline
\end{tabular}


Table F-2 cont'd. Petrographic analysis of thin sections.

\begin{tabular}{|c|c|c|c|}
\hline Sample ID & Unit & Rock & Description \\
\hline MS-12-34 & $\begin{array}{l}\text { Hunter Creek } \\
\text { at Neal Hot } \\
\text { Springs }\end{array}$ & Icelandite & $\begin{array}{l}\text { Contains sparse phenocrysts of plagioclase feldspar and } \\
\text { clinopyroxene. Plag phenocrysts and the cpx phenocrysts range } \\
\text { from moderately anhedral to euhedral. Two largest } \mathrm{cpx} \text { and at } \\
\text { least } 5 \text { plag phenocrysts show textures that are consistent with } \\
\text { being actively resorbed. The texture of the sample is aphanitic, } \\
\text { and the phenocryst content is between } 1-1.5 \% \text { at most. }\end{array}$ \\
\hline BW-14-37A & $\begin{array}{l}\text { Icelandite of } \\
\text { Alder Creek }\end{array}$ & Icelandite & $\begin{array}{l}\text { Aphanitic texture containing groundmass feldspar, magnetite, } \\
\text { clinopyroxene, and interstitial glass. Contains rare large (1-3.5 } \\
\text { mm) tabular plagioclase feldspar phenocrysts. }\end{array}$ \\
\hline BW-14-37B & $\begin{array}{l}\text { Icelandite of } \\
\text { Alder Creek }\end{array}$ & Icelandite & $\begin{array}{l}\text { Aphanitic texture containing groundmass feldspar, magnetite, } \\
\text { clinopyroxene, and interstitial glass. Contains rare large (1-3.5 } \\
\text { mm) tabular plagioclase feldspar phenocrysts. }\end{array}$ \\
\hline MC-106-16 & $\begin{array}{c}\text { Hunter Creek } \\
\text { Basalt }\end{array}$ & Icelandite & $\begin{array}{c}\text { Microlitic texture. Gray fine plagioclase lathe and brown-black } \\
\text { glass groundmass in PP, dark gray in XP. } 0 \text { - } 5 \% \text { euhedral } \\
\text { plagioclase phenocrysts, simple twinning. Opaque minerals are } \\
\text { probably magnetite. (Cruz, 2017) }\end{array}$ \\
\hline MC-98-16 & $\begin{array}{c}\text { Hunter Creek } \\
\text { Basalt }\end{array}$ & Icelandite & $\begin{array}{c}\text { Microlitic texture. Gray fine plagioclase lathe and brown-black } \\
\text { glass groundmass in PP, dark gray in XP. } 0 \text { - } 5 \% \text { euhedral } \\
\text { plagioclase phenocrysts, simple twinning. Opaque minerals are } \\
\text { probably magnetite. (Cruz, 2017) }\end{array}$ \\
\hline MC-15-16 & $\begin{array}{c}\text { Hunter Creek } \\
\text { Basalt }\end{array}$ & Icelandite & $\begin{array}{c}\text { Microlitic texture. Gray fine plagioclase lathe and brown-black } \\
\text { glass groundmass in PP, dark gray in XP. Opaque minerals are } \\
\text { probably magnetite. (Cruz, 2017) }\end{array}$ \\
\hline MC-18-16 & $\begin{array}{c}\text { Hunter Creek } \\
\text { Basalt }\end{array}$ & Icelandite & $\begin{array}{l}\text { Microlitic texture. Gray fine plagioclase lathe and brown-black } \\
\text { glass groundmass in PP, dark gray in XP. Opaque minerals are } \\
\text { probably magnetite. (Cruz, 2017) }\end{array}$ \\
\hline MC-101-16 & $\begin{array}{l}\text { Hunter Creek } \\
\text { Basalt/DIT2? }\end{array}$ & Tuff? & $\begin{array}{l}\text { Microlitic texture. Brown glass, with calcite replacing plagioclase } \\
\text { and/or glass. Circular zeolite along contact with DIT2.Opaque } \\
\text { minerals are probably magnetite. (Cruz, 2017) }\end{array}$ \\
\hline
\end{tabular}

Thin section images on pages $145-171$ are taken at 100x magnification. 


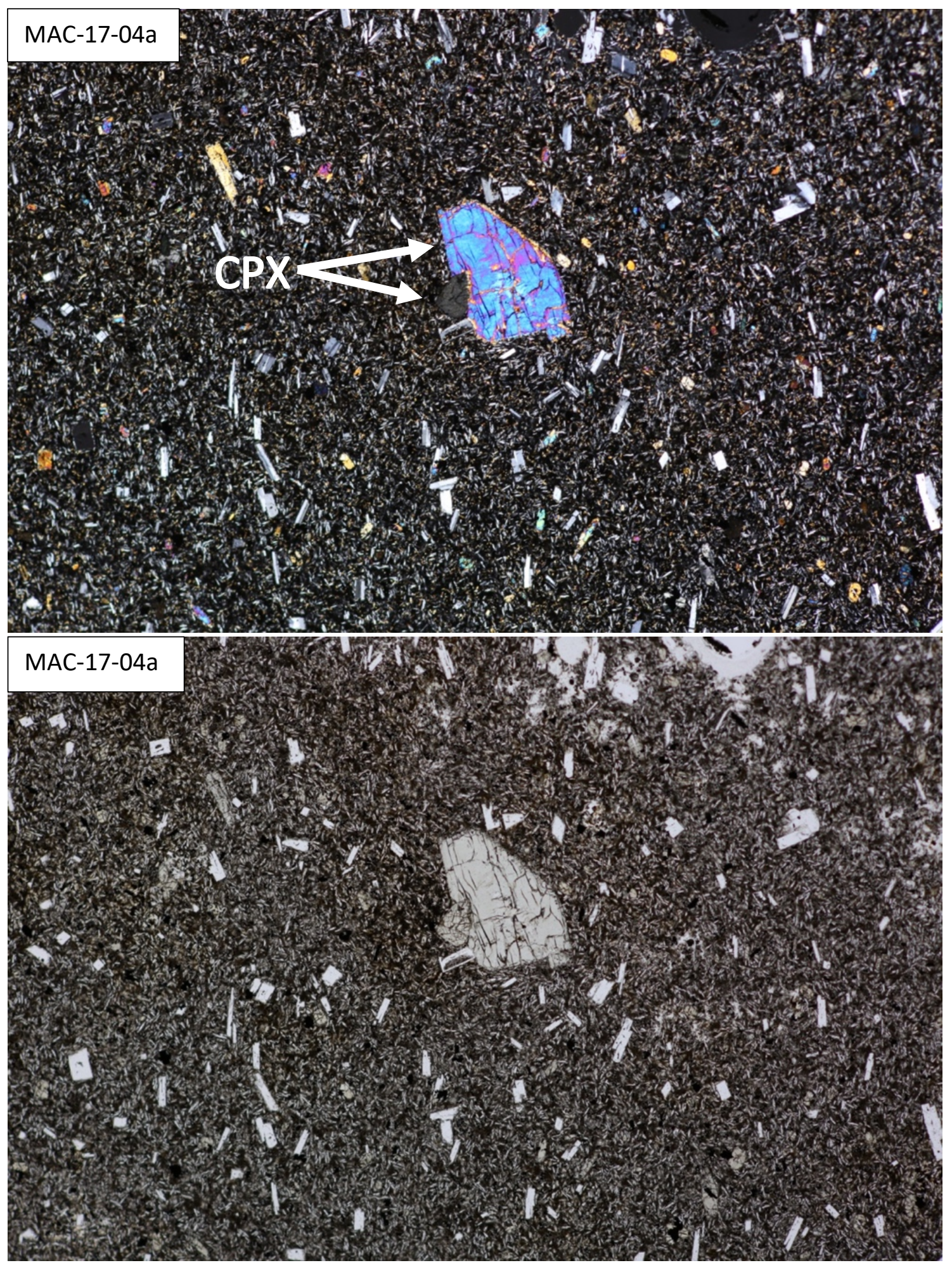




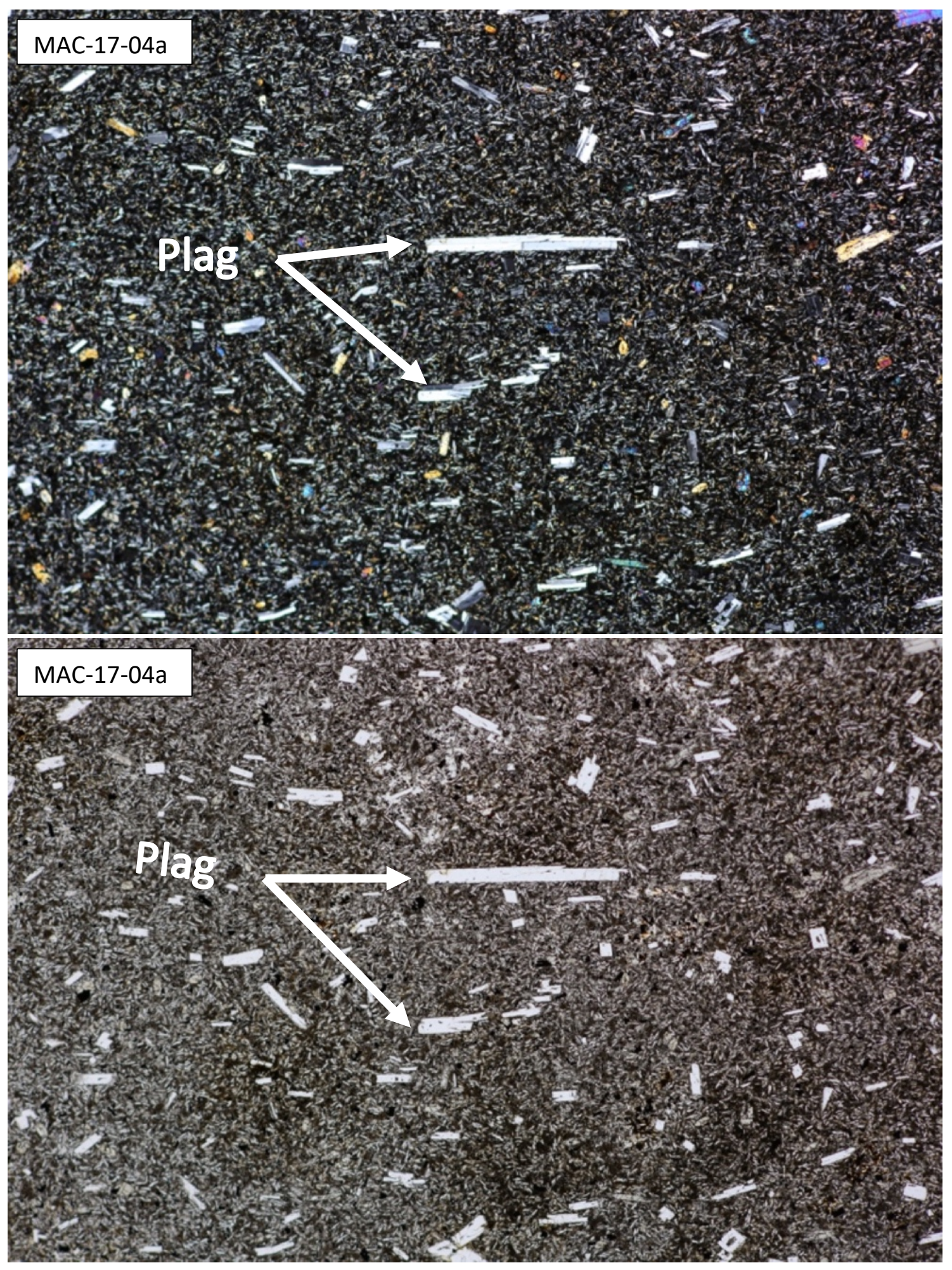




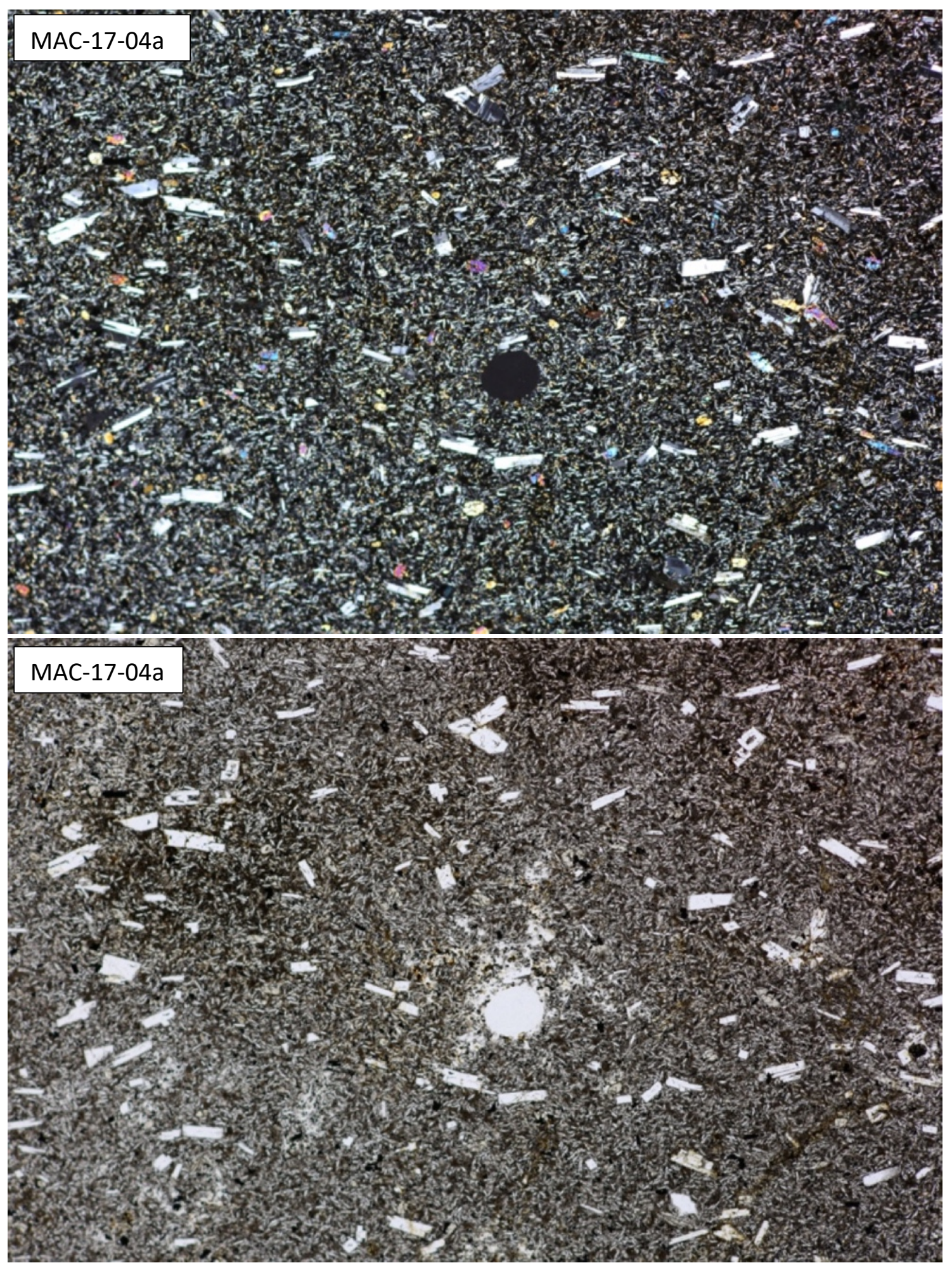




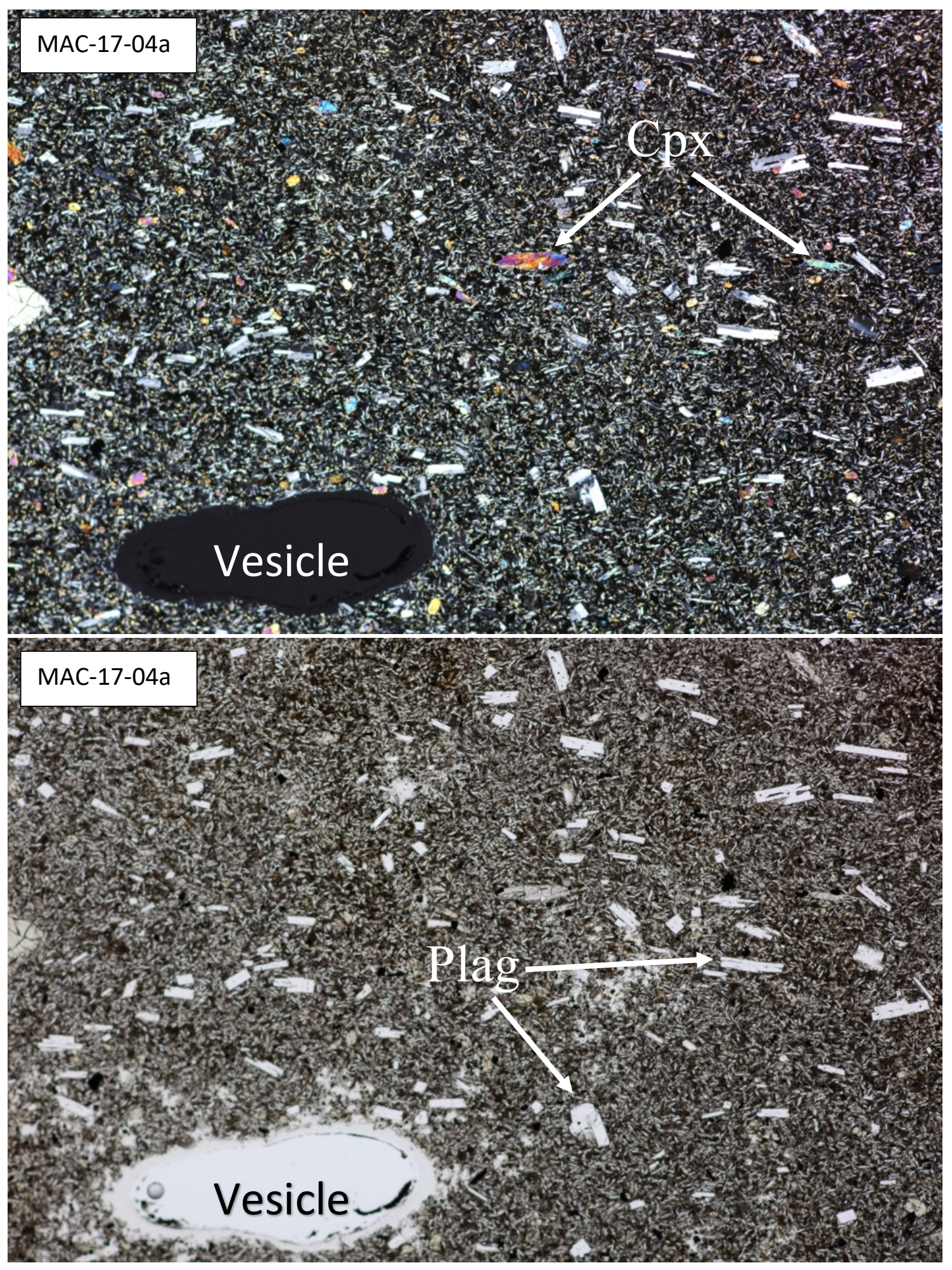




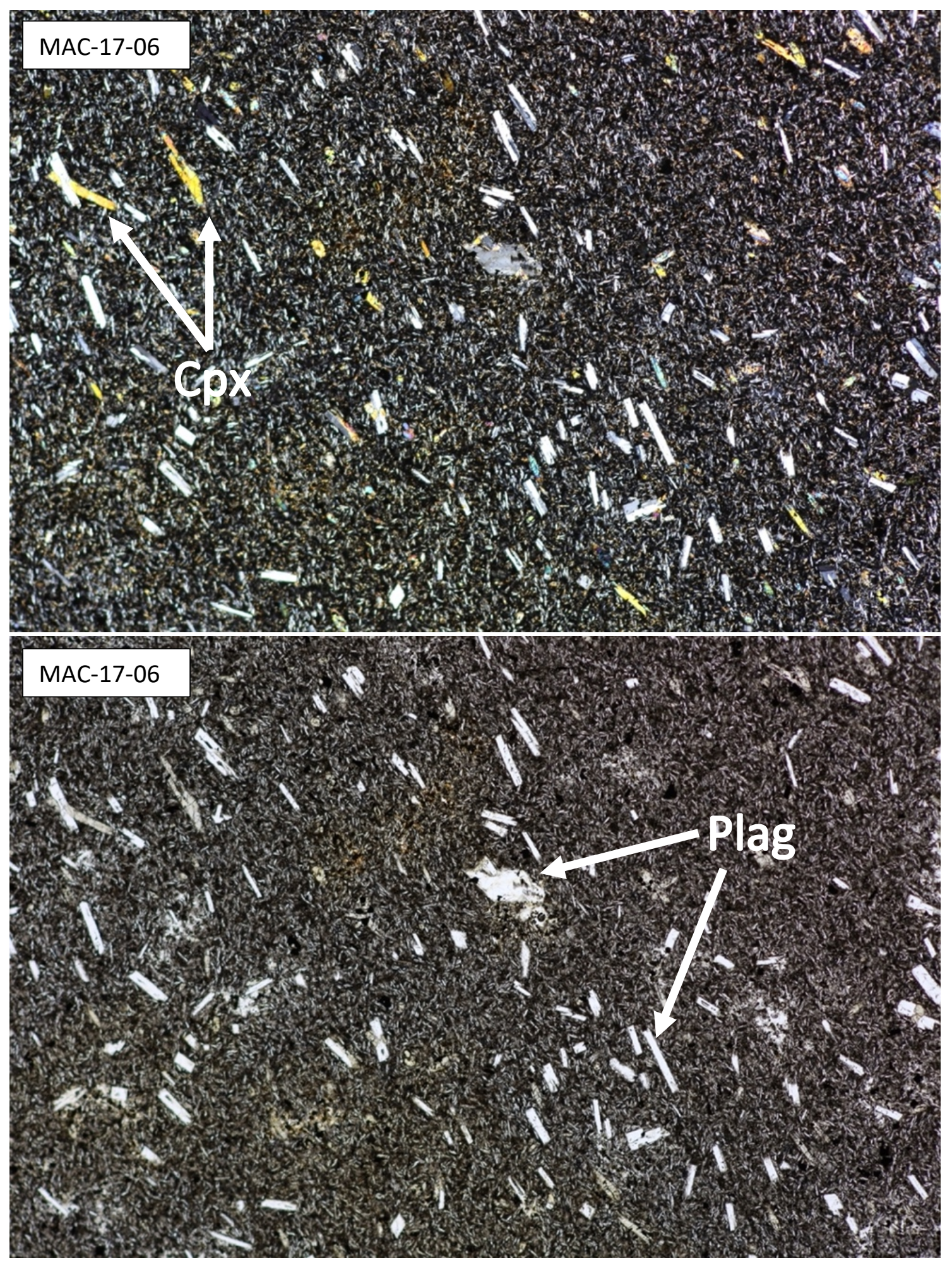




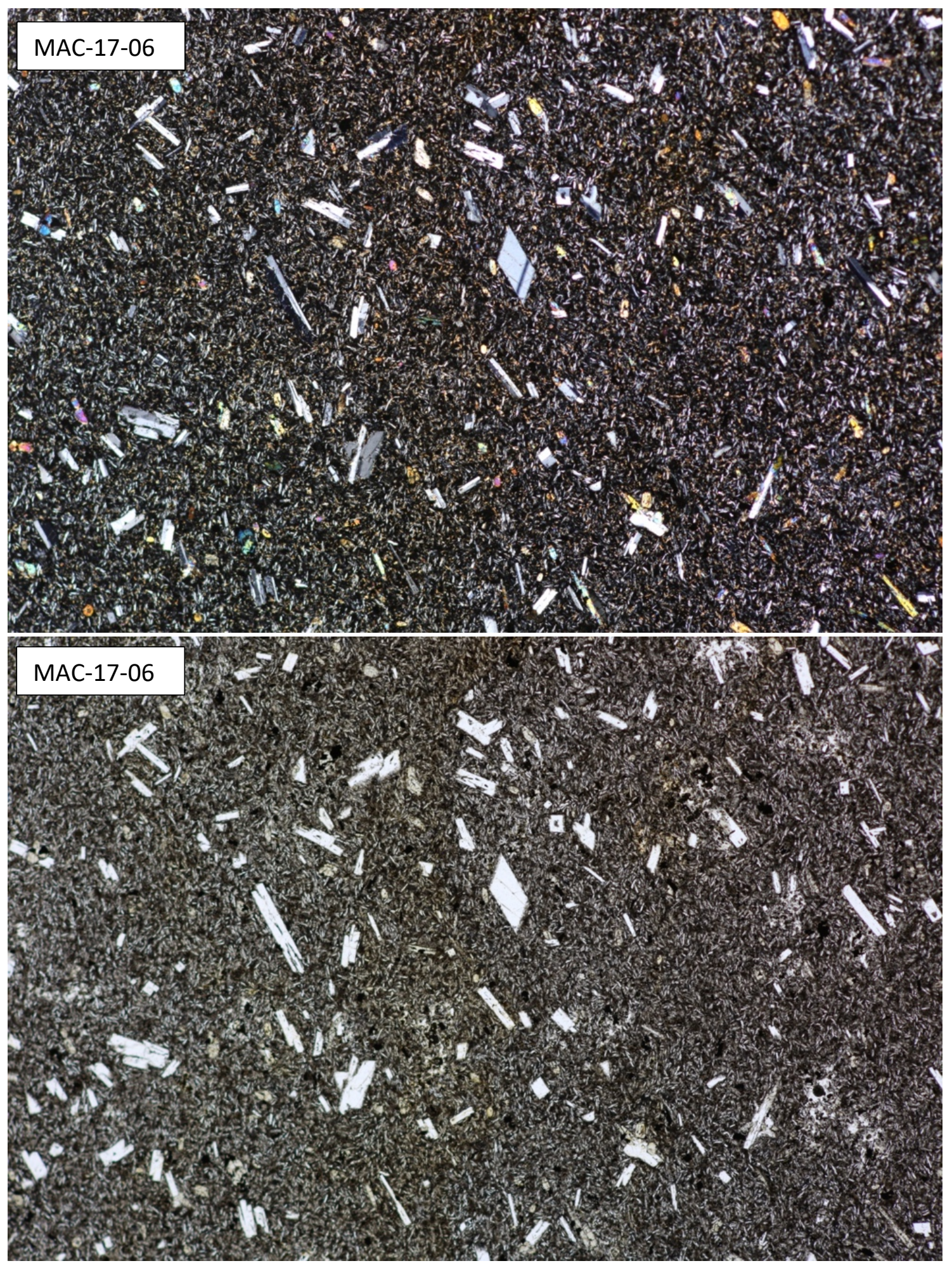




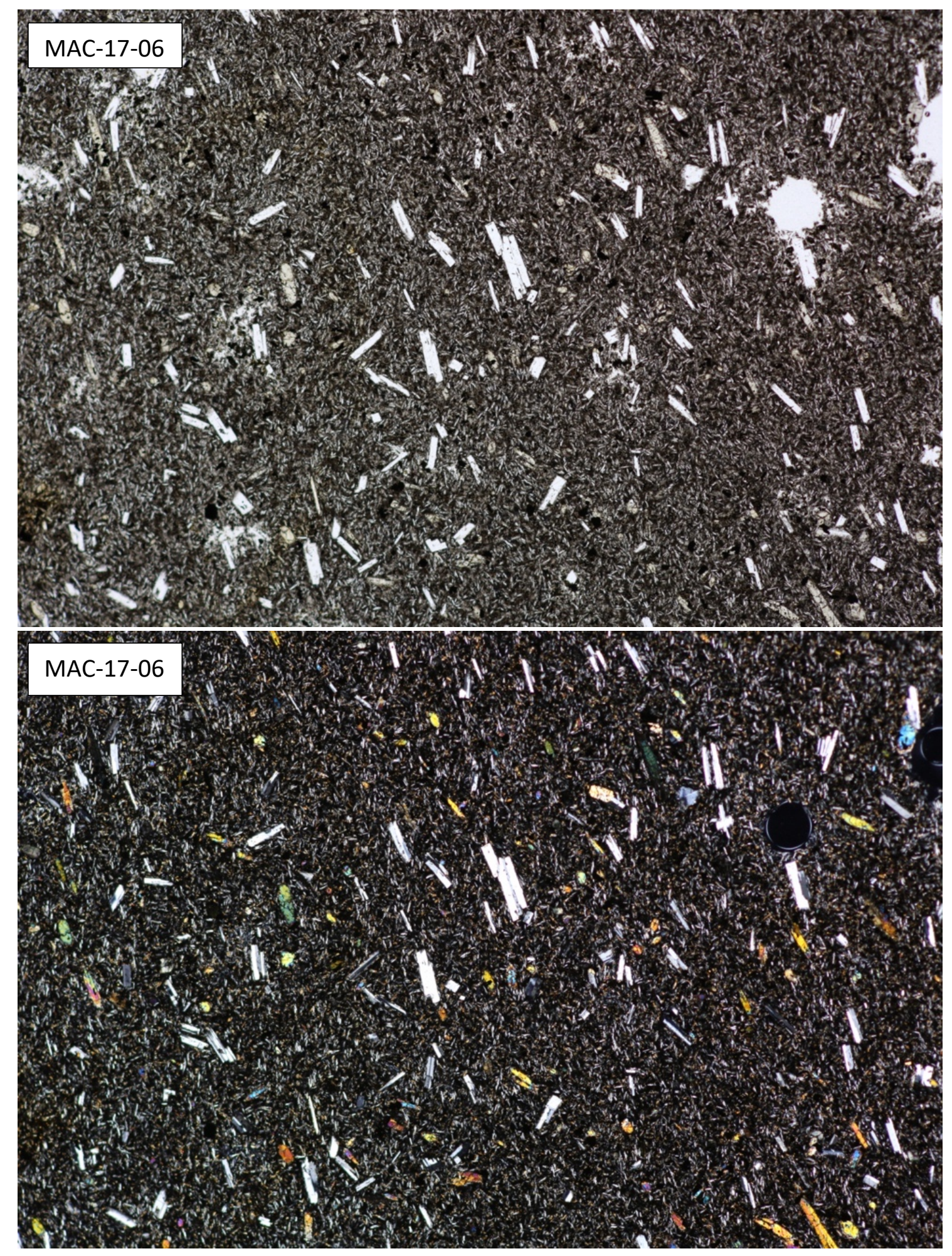




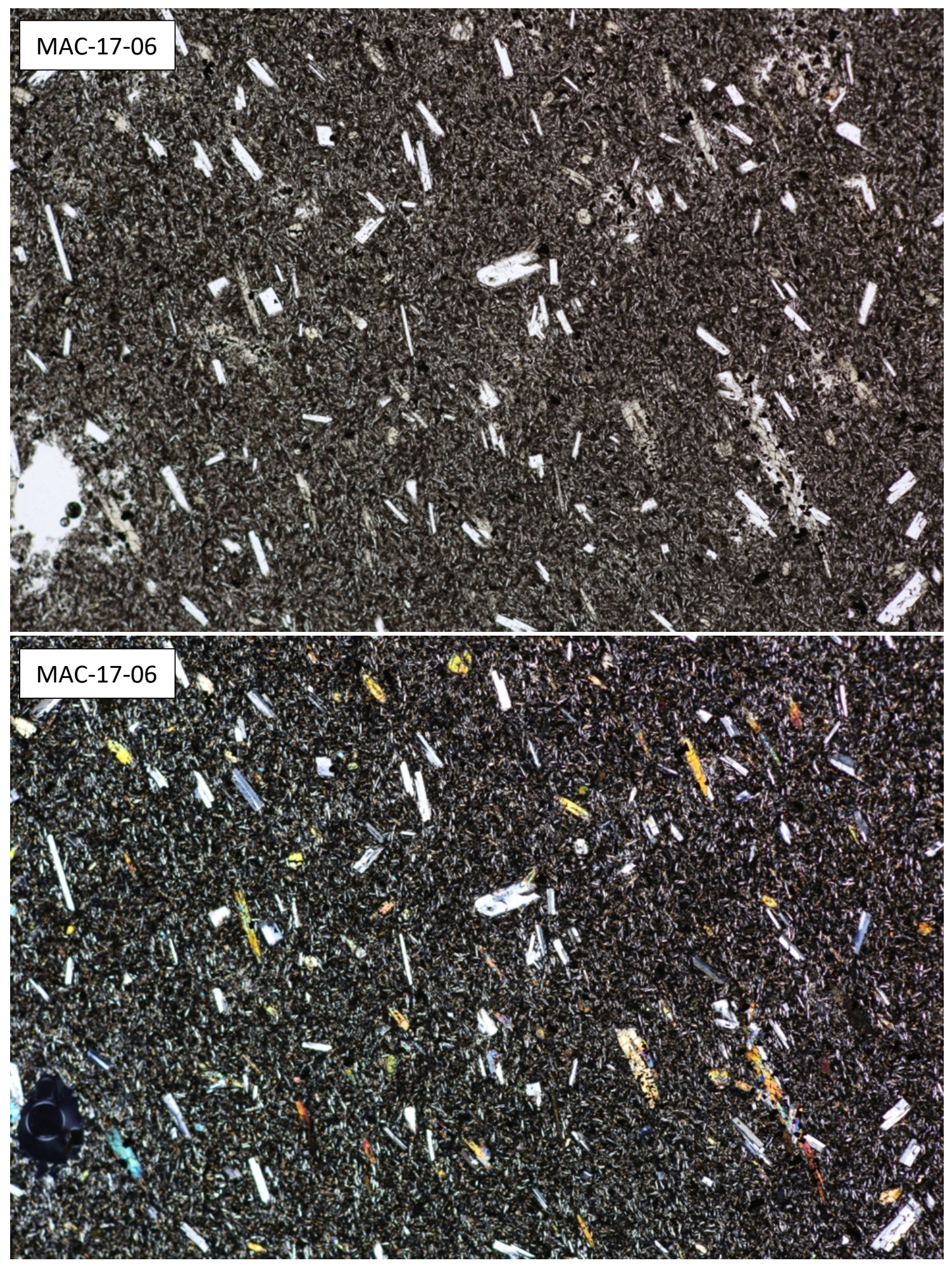




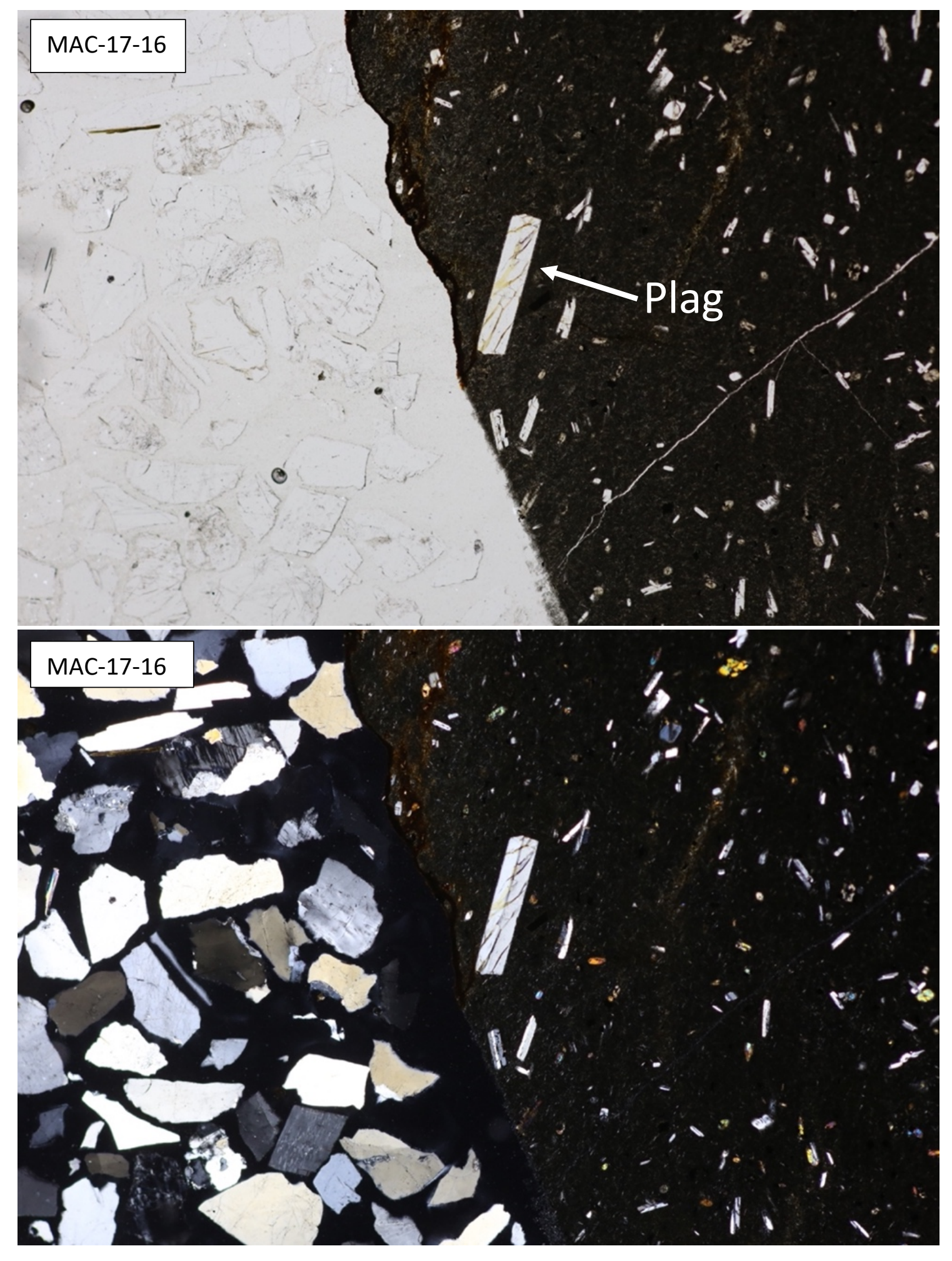




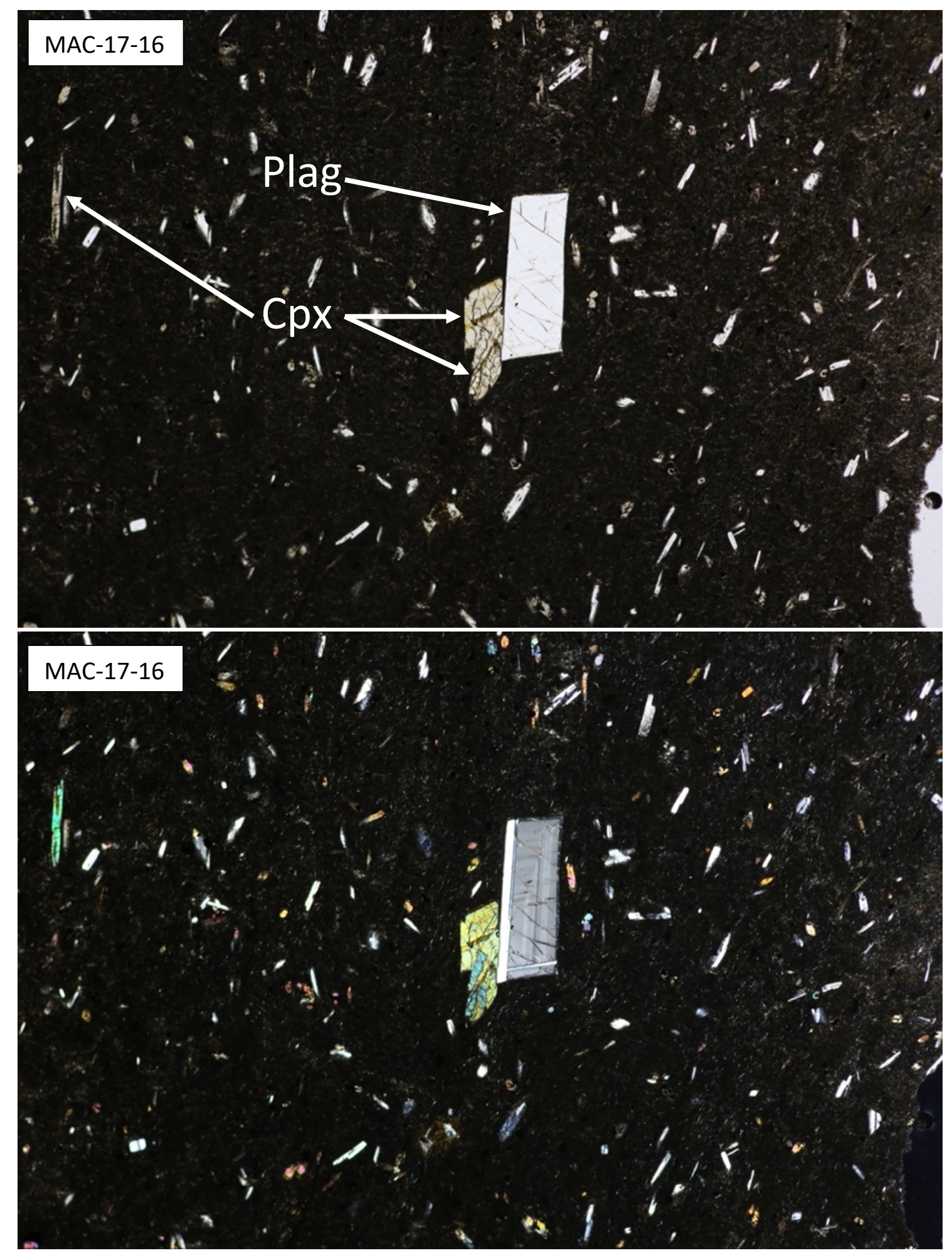




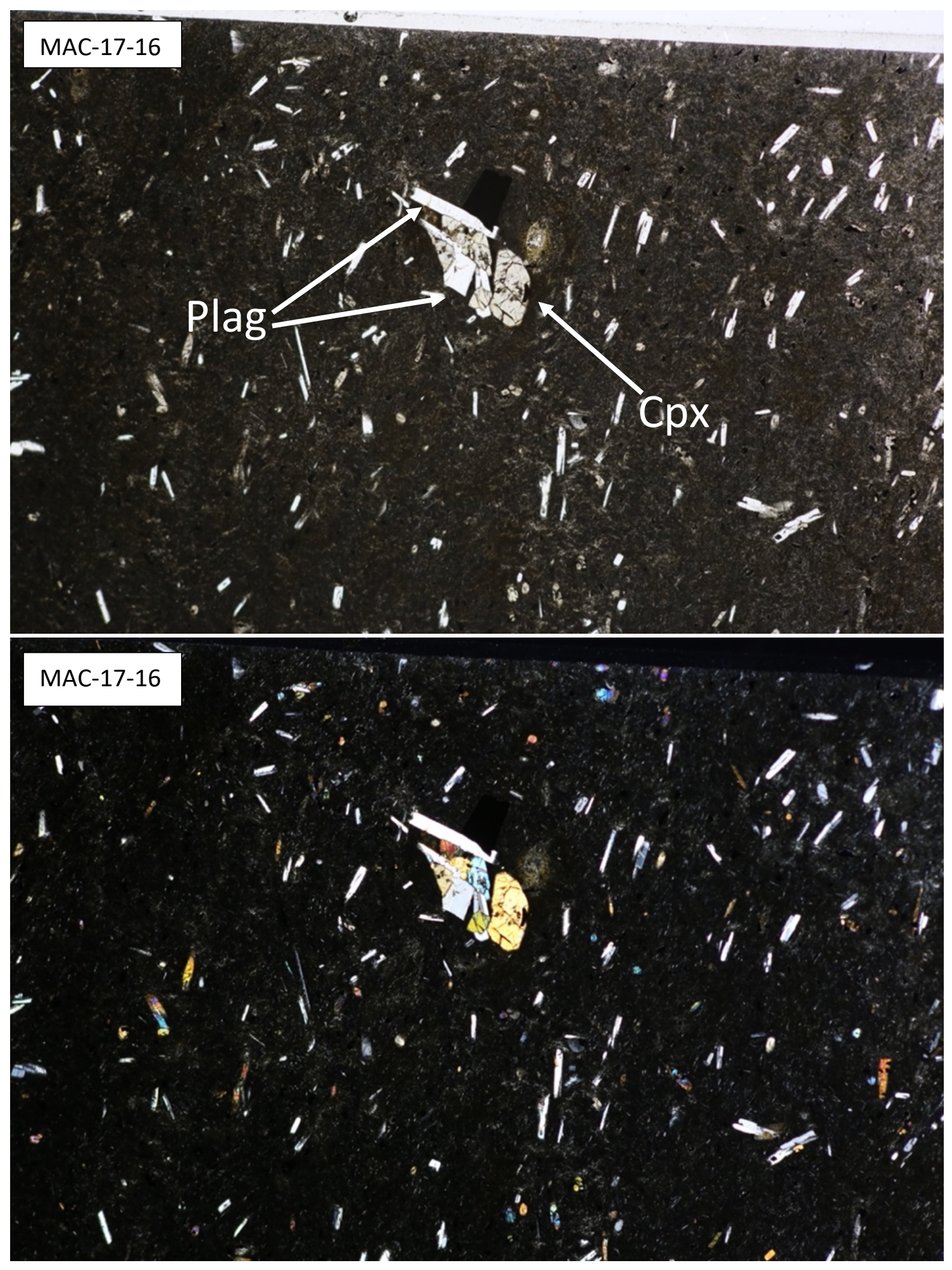




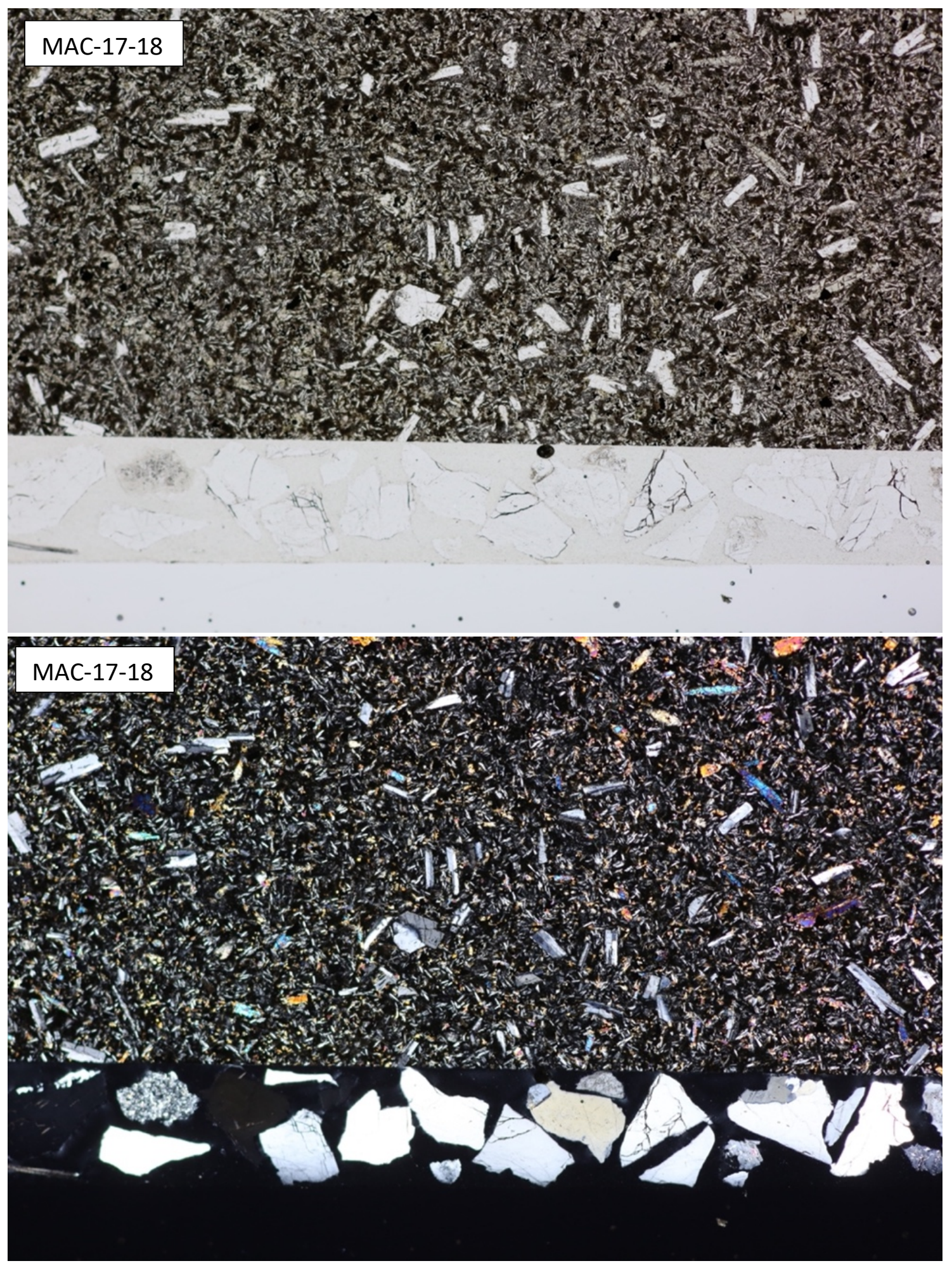



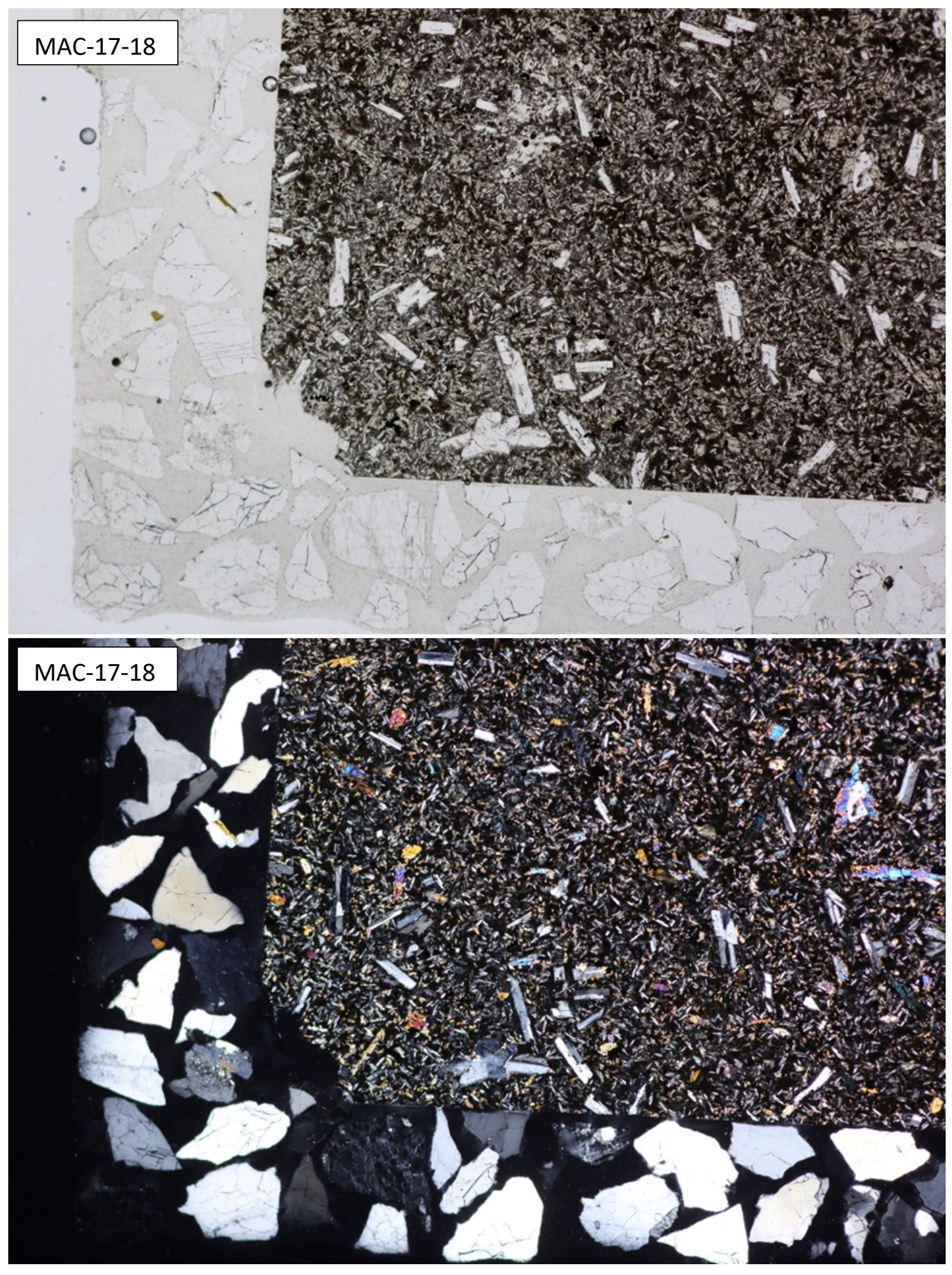


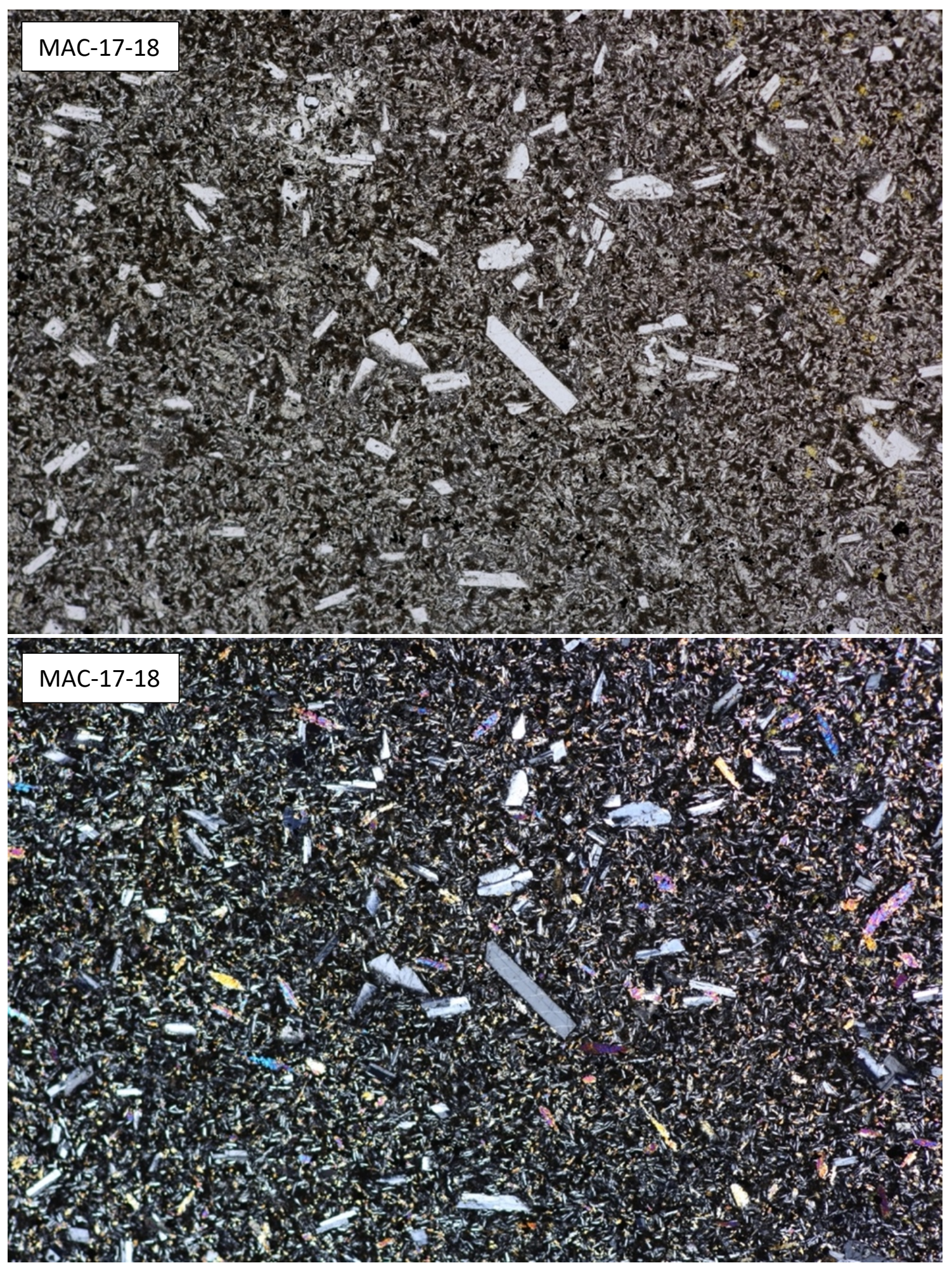




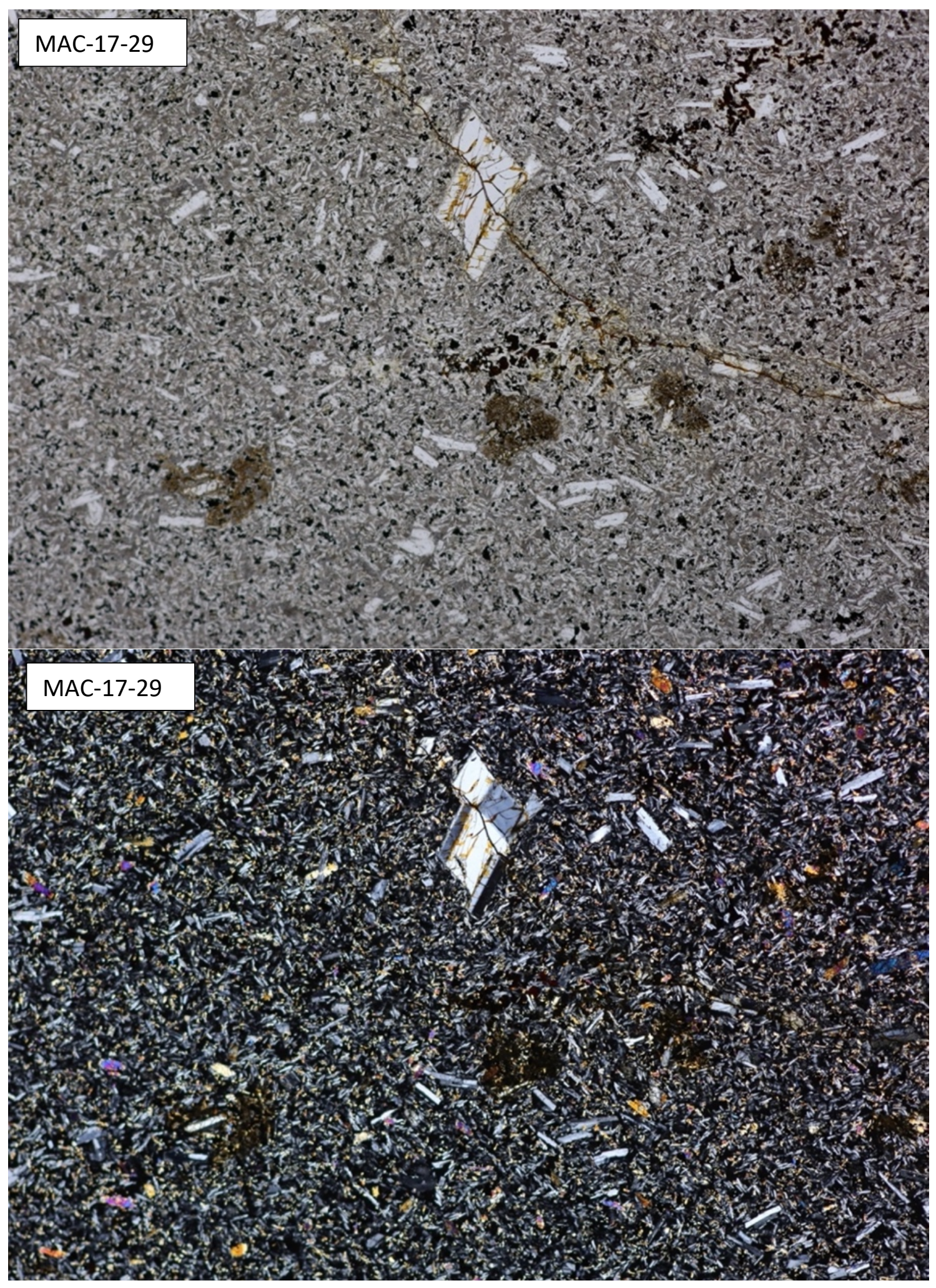




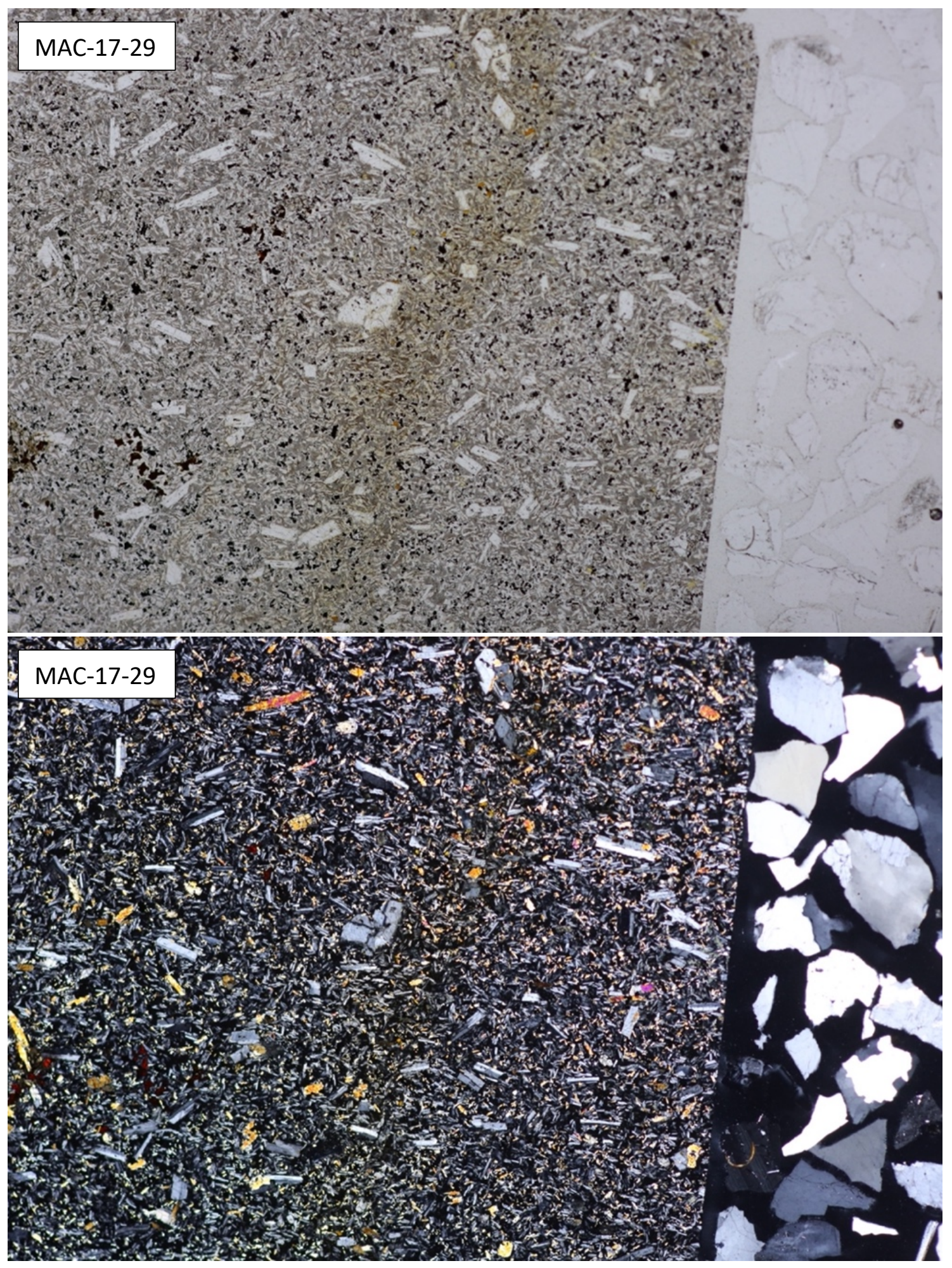




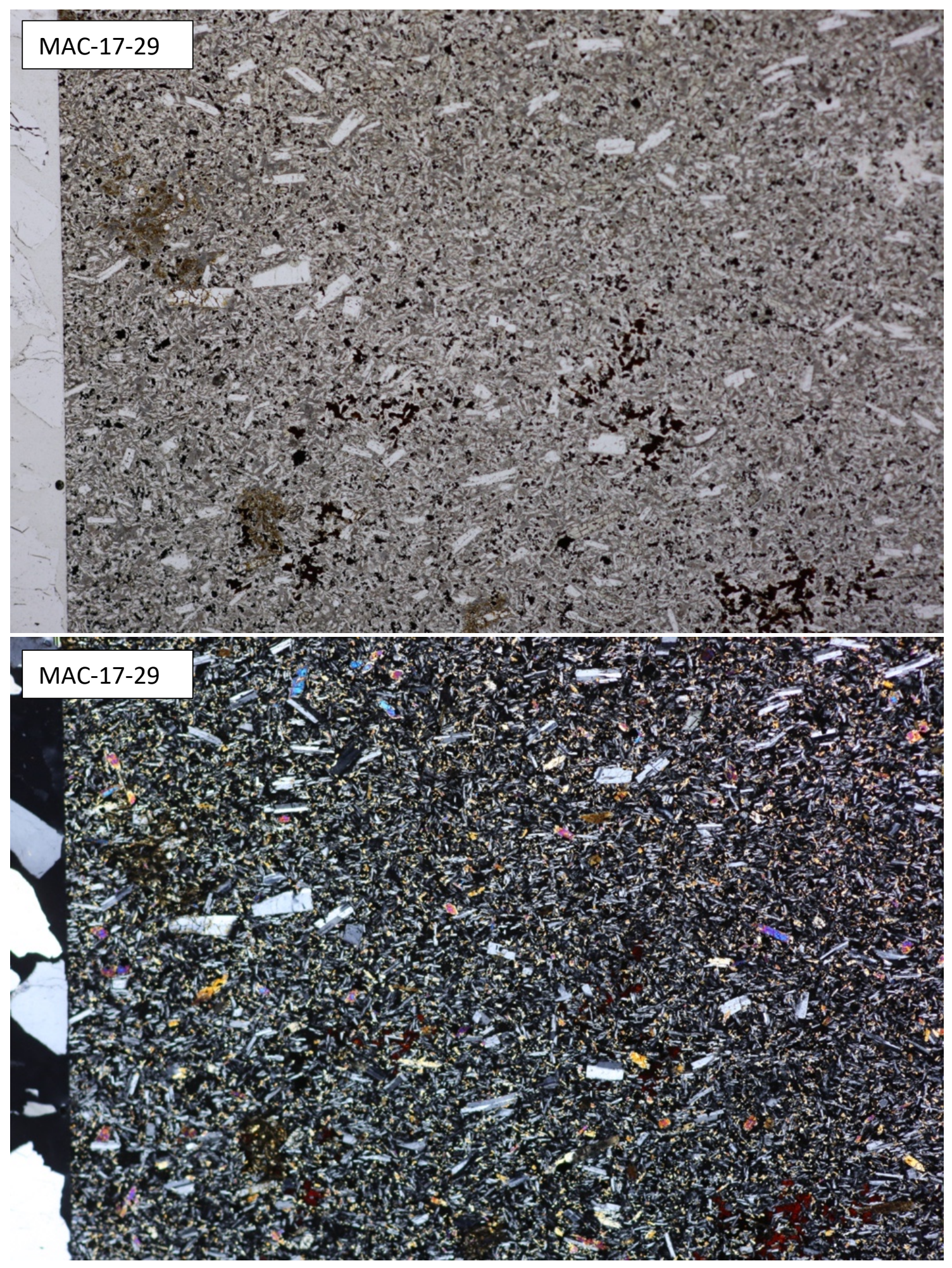




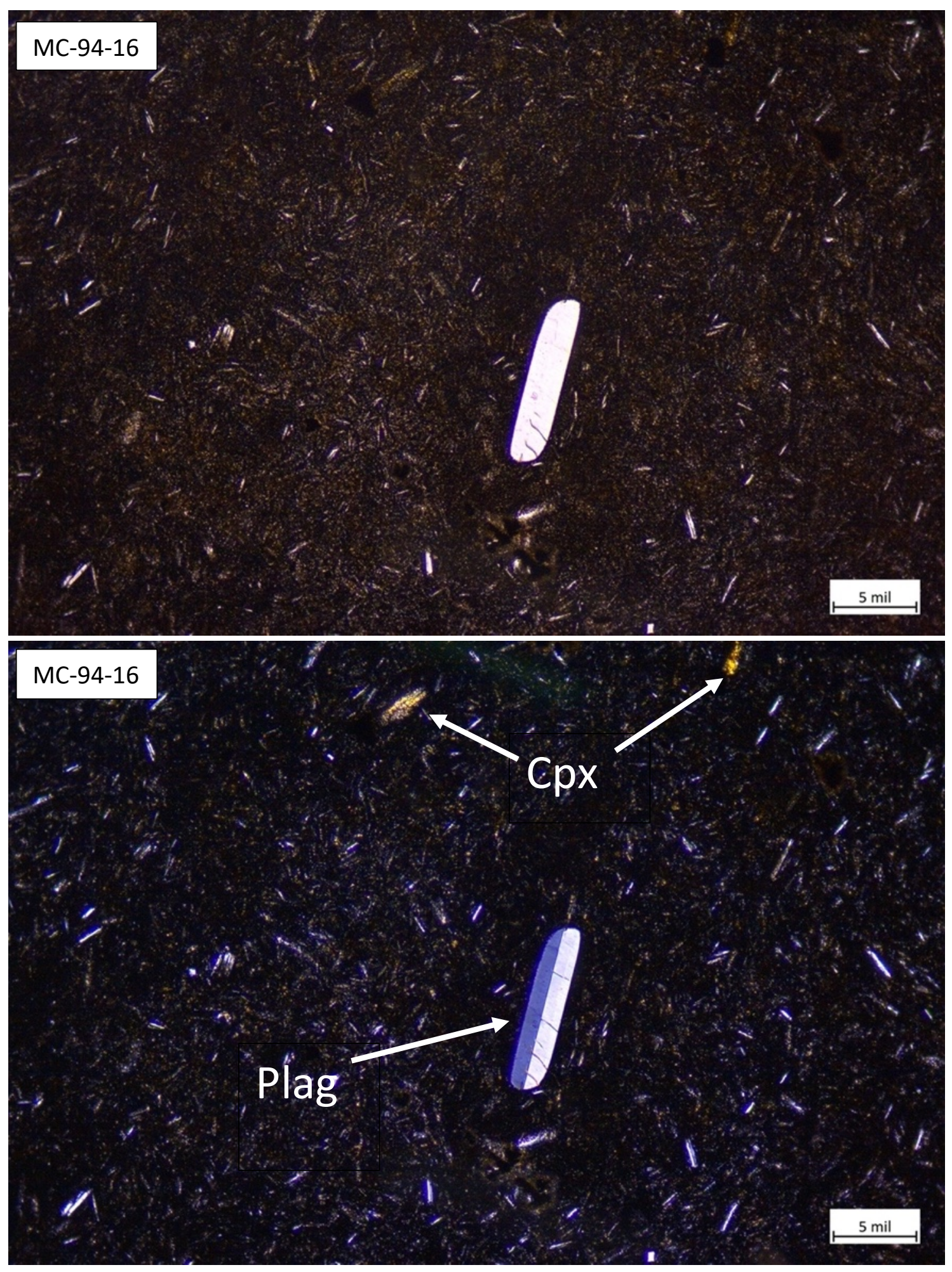




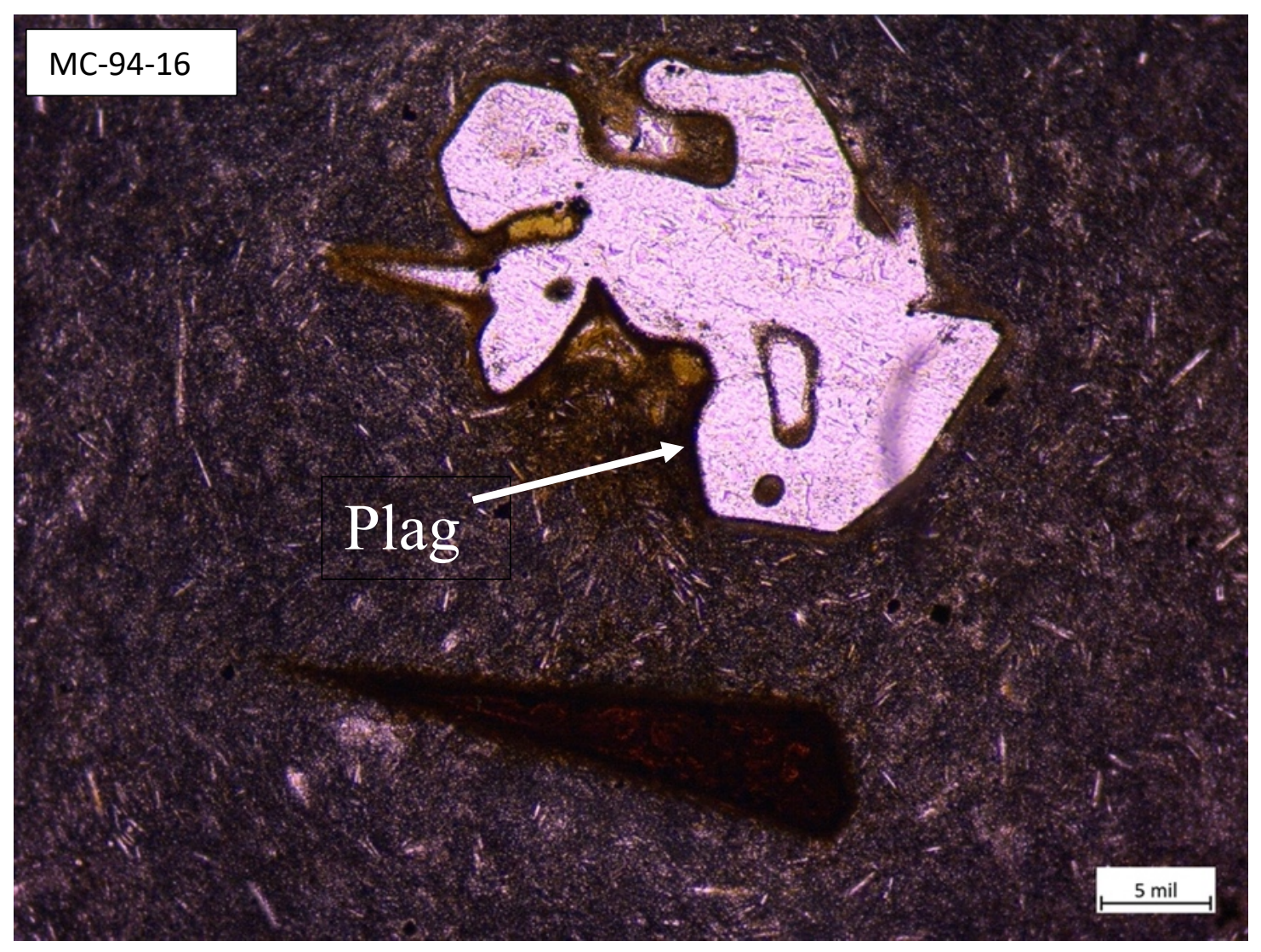




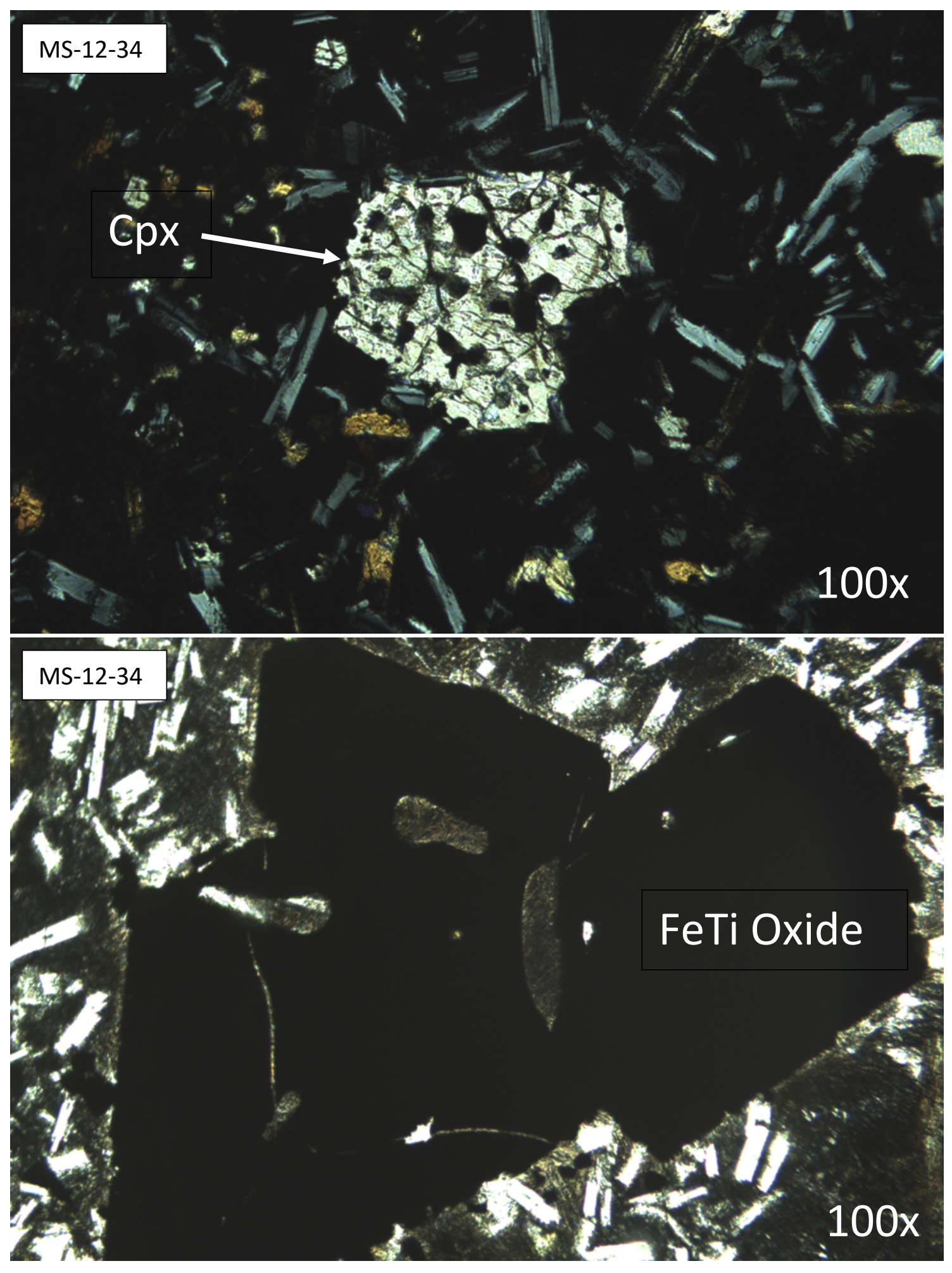




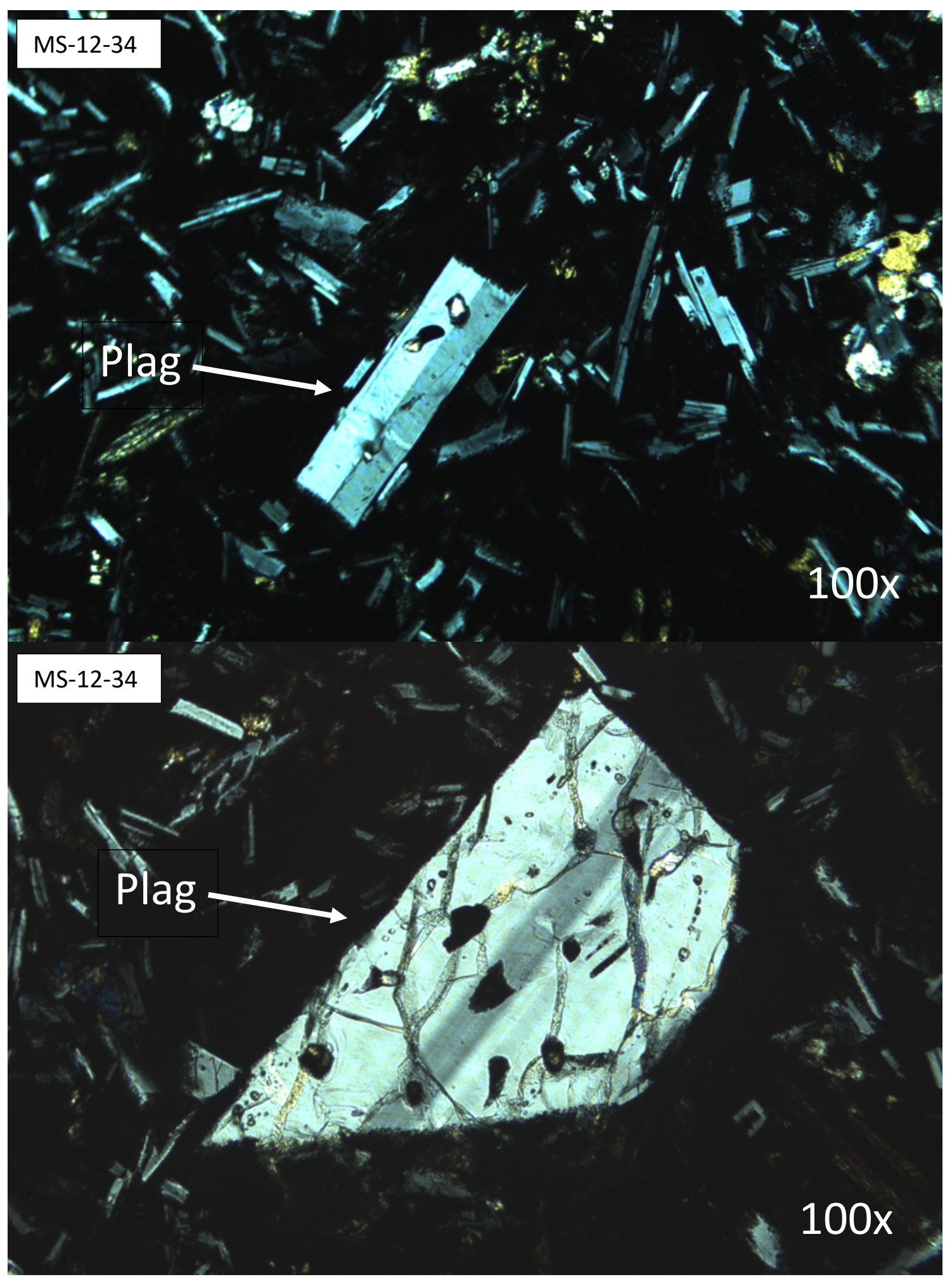

